
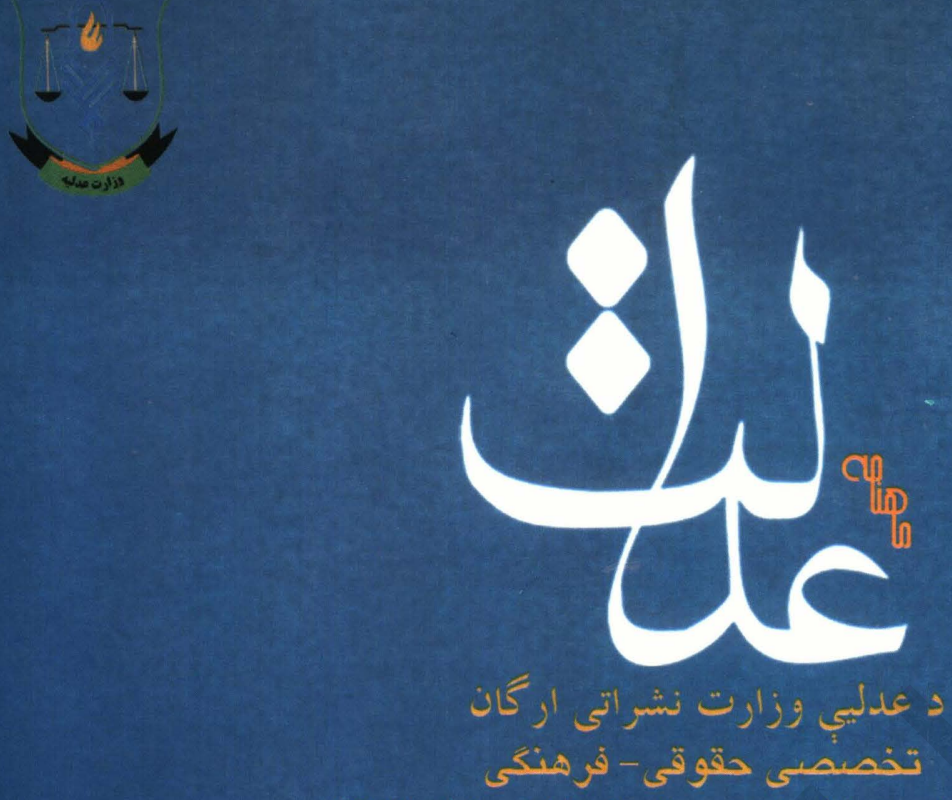

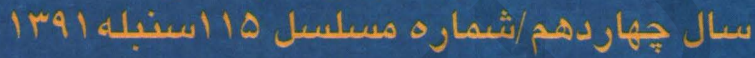




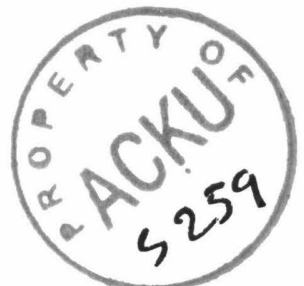

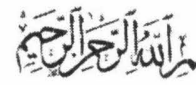

ماهنامهى تخصصى، حقوقى و فرهنگى - سال جهاردهم / شمارهى مسلسل ه1| / سنبله |q"|

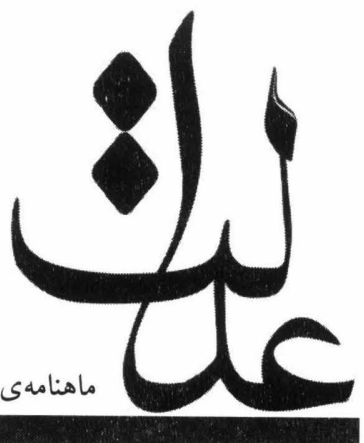

$$
\begin{aligned}
& \text { ه قانونمل محمد رحيم دقيق، } \\
& \text { ه }
\end{aligned}
$$

صاحب امتياز

وزارت عدليه د. ج . 1.1

مدير مسوول

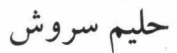

$(\cdot \ln 14 \cdot$. I9VA)

ويراستار

عبدالقيوم قيومى

ديزاين جلد و صفحه آرايى إقايى

امان الله صداقت (غيتى صفح اريى)

امور تايب و حروفجينى

عبدالكريم قريشى و محمد فهيم صادقى تهرو
Website: www.moj.gov.af

E-mail: adalat@moj.gov.af

قيمت •ه افغانى 


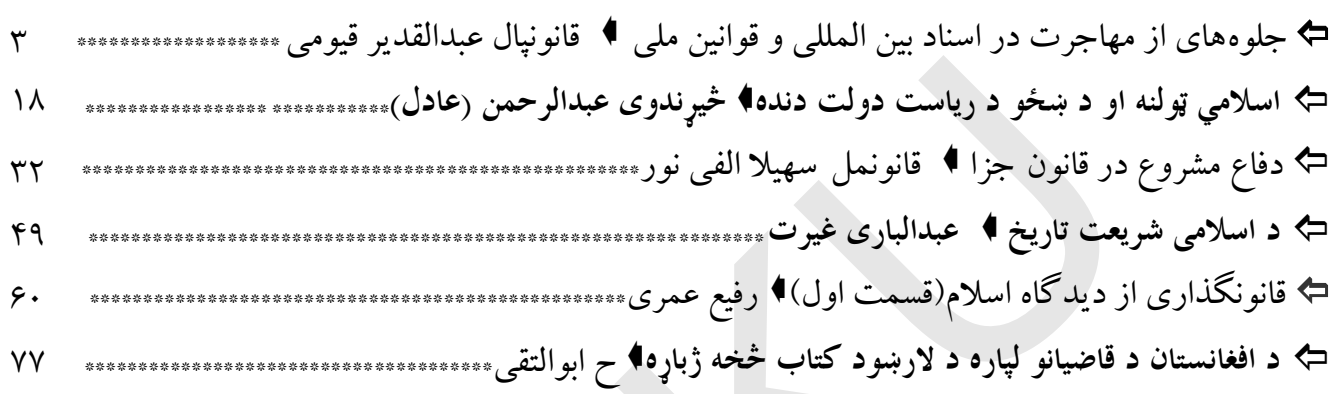
ل] [َزارشها

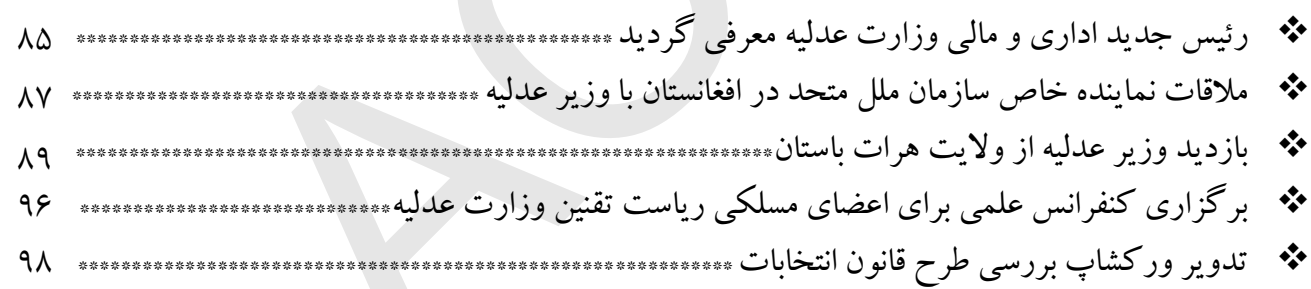




\section{هلوه هاى از دهاهرت}

\section{در اسناد بين الهللى و قوانيت هلى}

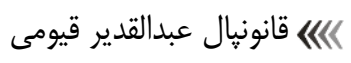

مهاجرت از يديده هاى ارج كزار تاريخ بشريت بوده ، يِيشينٔ آن به هزاران سال مى رسد

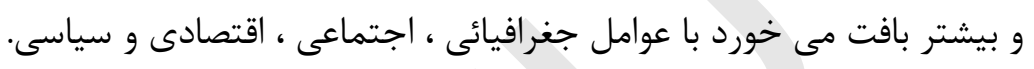

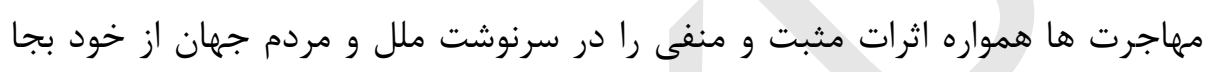

كذاشته كَاهى راه گَشاى اختلاط و انتقال مدنيت هاى درخشان ترديده است كه نميتوان

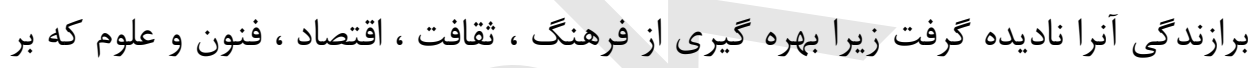

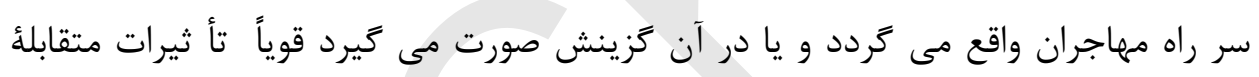
حود را ميان كشور ها دارد.

مهاجرت ها همواره برون از قلمرو ملى و بعضاً بداخل كشور صورت مى كيرد و در قرون حاضر به علل بروز تهاجم بيكانه بر كشورى ، حوادث نا شى از كشمكش هاى داخلى وهم

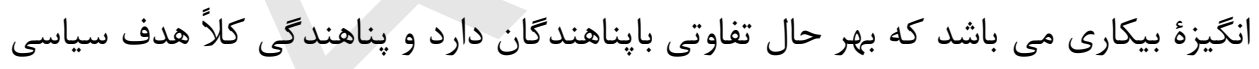

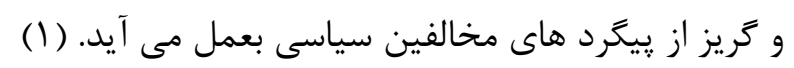

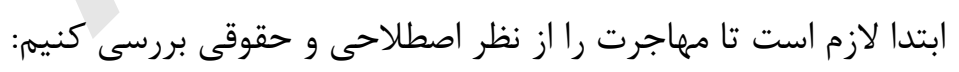

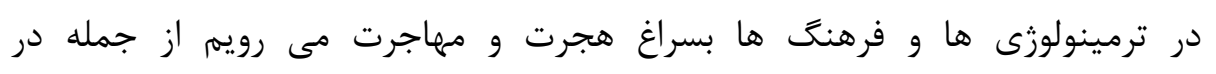

ترمينولوزى حقوق تعريف مهاجرت را جنين مى يابيم. .

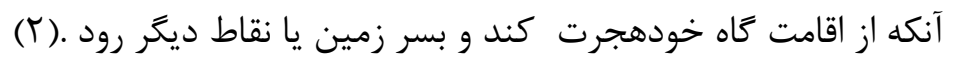
و نيز در همين كتاب آمده است:

هجرت ضد وصل و يِيوند است و بيرون شدن از سرزمينى است به سرزمين ديكر. 
در فرهنگ اسلامى رفتن رسول اكرم (ص) و ياران اوست از دولتشهر مكه به يثرب

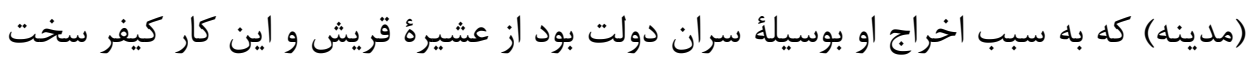

$$
\text { در نظام عشايرى تلقى مى شد.. }
$$

قرآن و تورات اين كيفر را محكوم كرده اند ، اين هجرت بزودى باعث تشكيل دولت اسلامى مدينه در برابر دولتشهر مكه شد و موجب در هم شكستن نظام عشايرى دولتشهر آنرات

$$
\text { مكه و فتح آن كرديد. }
$$

دولت اسلامى مدينه هجرت و جهاد را دو خايه و دو اصل نظام سياسى خود قرار داد و

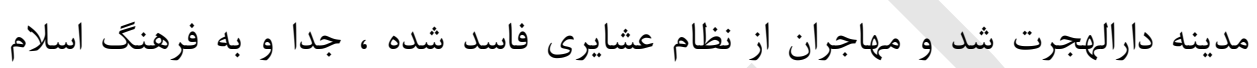
ي يوستند.

دولت اسلامى مدينه ظرف ده سال سراسر عربستان را از ايلات (خليج عقبه ) تا بحرين ،

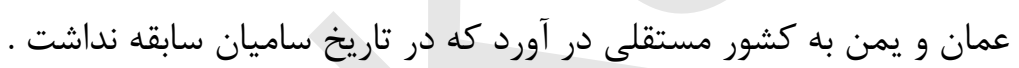

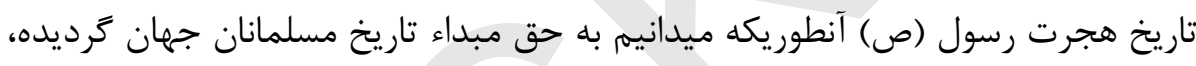

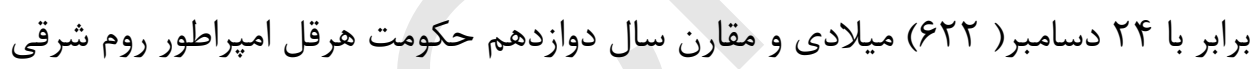
بوده است. مزاياى هجرت به مدينه عبارت بود از:

$$
\text { 1 - دريافت مستمرى از عايدات دولتى (فيئى). }
$$
r- خواندن و نوشتن و فرا كيرى تعليم قرآن وحديث.

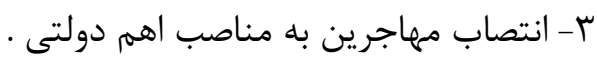

$$
\text { F أ- مزاياى حقوق مدنى در ارث. }
$$

ه- تآ مين اجتماعى كه نظام عشايرى فاقد آن بود اما نو مسلمان مهاجر كه قطع رابطه با دان

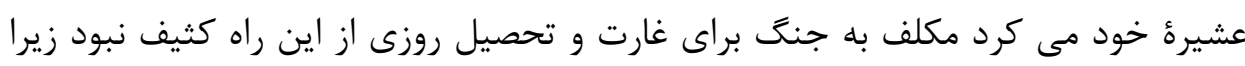

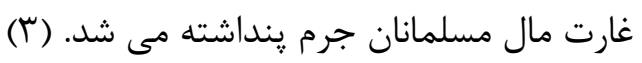

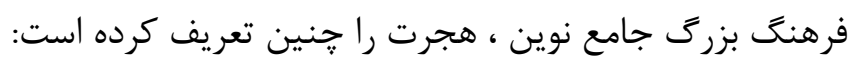

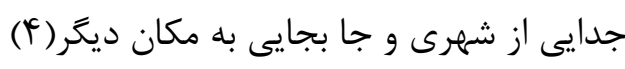




$$
\text { فرهنَ يك جلدى معين درتعريف هجرت آورده است: }
$$

جدا شدن ، جدايى كردن ، رحلت كردن ، هجرت كردن ، ترك وطن كفارو انتقال به دارالسلام (ه) در جلد جهارم فرهنَ معين مهاجر تعريف شده كه: كسى كه از مؤطن خود به جائى نقل مكان كرده باشد، كسى كه از مكه همراه يُ بيامبر به

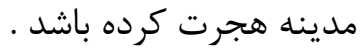

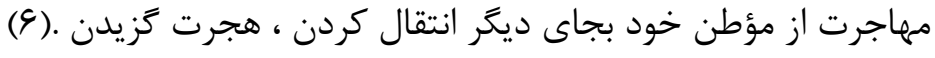

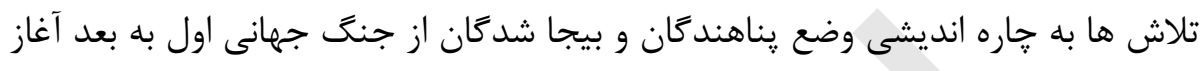

در سال |9r| داكترفريجاف نانس از سوى جامعأ ملل به كمشنرى عالى يناهندگان

$$
\text { روسى برگزيده مى شودكه وظايف: }
$$

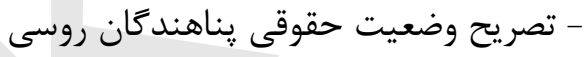

- سازمان دهى بازگشت يا جادادن آنها در كشور هاى قادر به يذيرش.

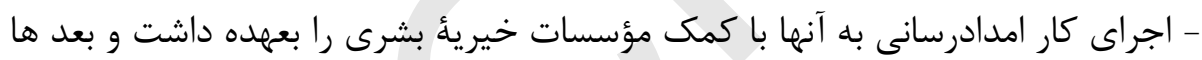

قيموميت ساير گروب هاى يناهنده را نيز بدوش خرفت كه اين گروه ها عمدتأ ارمنى ها

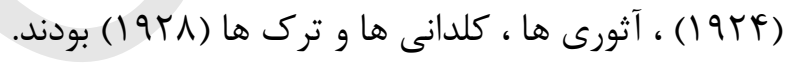

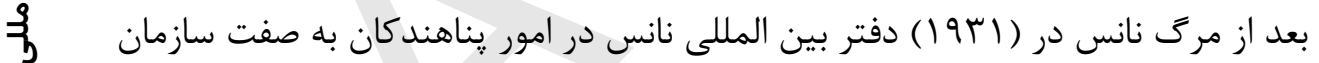
خود مختار تحت نظر جامعهُ ملل بوجود آمده در سال (سب9 () همين كه هتلر به قدرت رسيد ، كمشنر عالى امور يناهندًان براى اهل آلمان تأسيس شد ـ اين دفاتر امور بشر

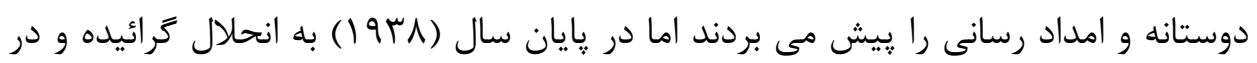

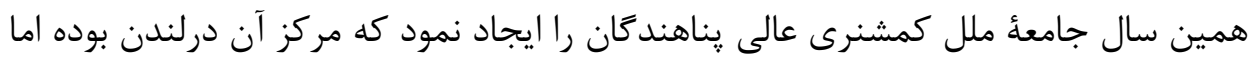
فعاليت اين مركز محدود و در(949 (19) خاتمه يافت. در سال (1941) يس از كنفرانس اويان براى بررسى مسئله مهاجرت غير داوطلبانه از آلمان و اتريش، كميتهُ دول در امور يناهندگان نيز بوجود آمده اين كميته در خلال جنى جهانى دوم فرا گير شد در سال (9FV (1) سازمان بين المللى يناهندكان جاگزين آن كرديد. 
در ساليان جنَ جهانى دوم مليون ها انسان مجبور به ترك كشور هاى شان كرديدند

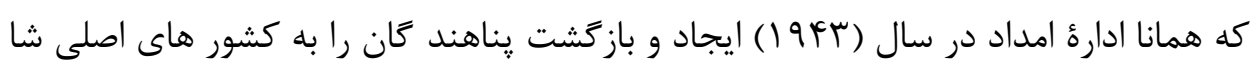

$$
\text { ن سازماندهى كرد. }
$$

با تدوير كنفرانس يرمود در همين سال تمام كسانى كه در اثر رويدادهاى تلخ ارويا

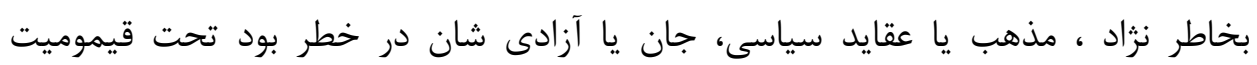

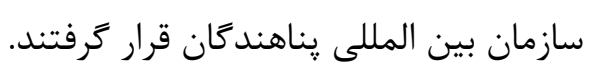

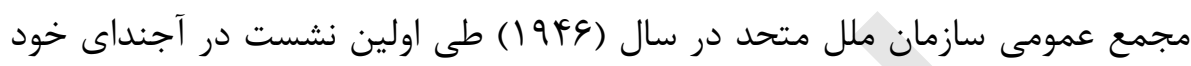

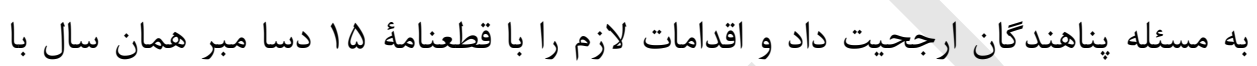

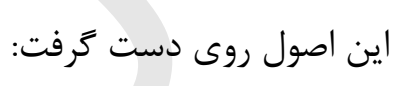

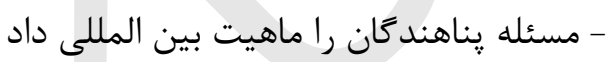

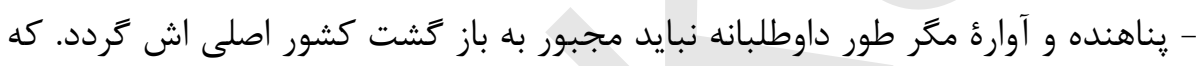

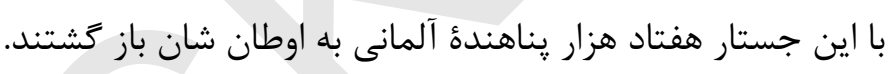

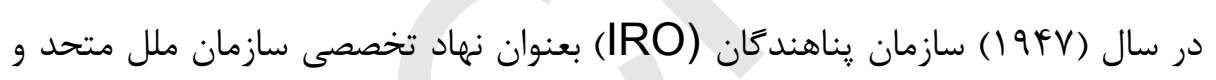

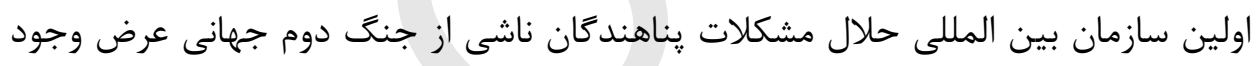

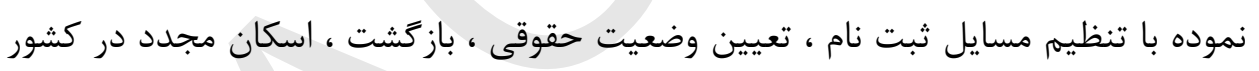
ديخر و حمايت هاى سياسى و حقوقى بناهندكان تا سال (1901) به فعاليت خود ادامه داد.

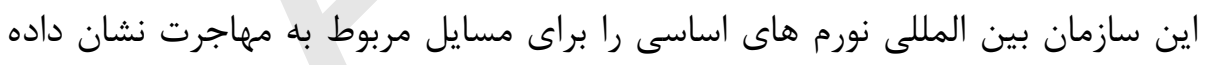

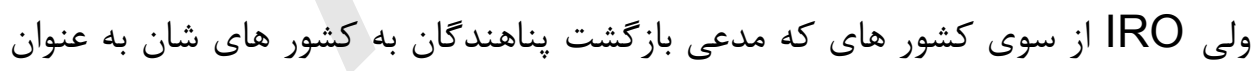

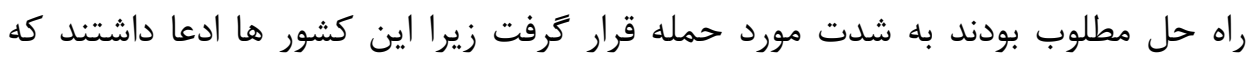

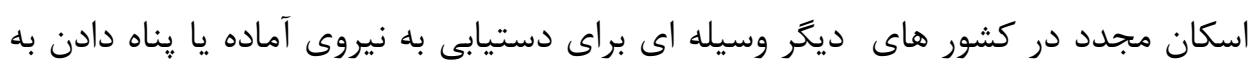

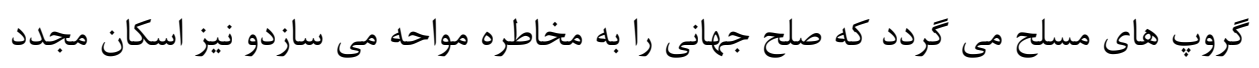

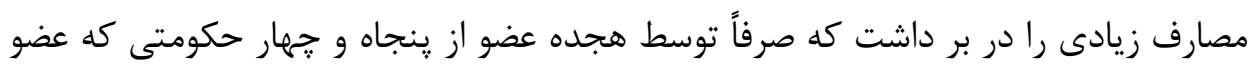
سازمان ملل متحد بودند ، تمويل مى كرديد. 
اما تأسيس كمشنرى عالى سازمان ملل متحد در امور بناهندمان (UNHCR) در (ر)

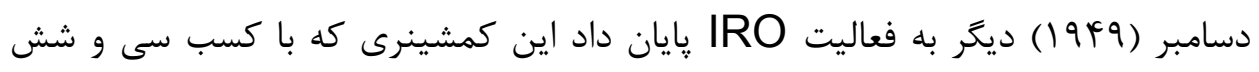

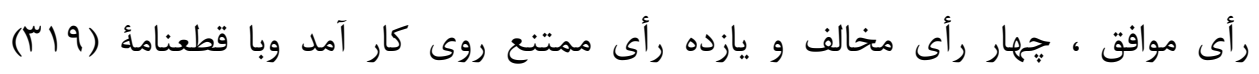

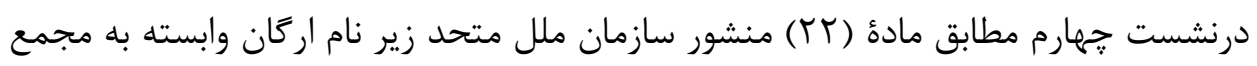

$$
\text { عمومى در اول جنورى (1901) به فعاليت آغاز نمود. }
$$

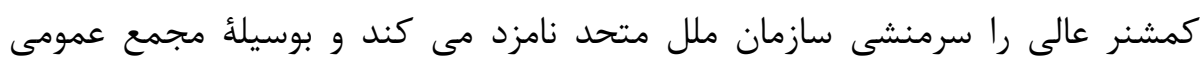

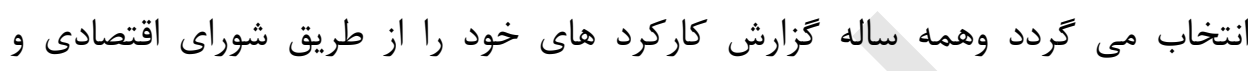
اجتماعى (ECOSOC) به مجمع عمومى ارائه مى دهد. (V)

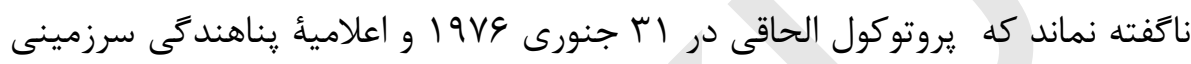

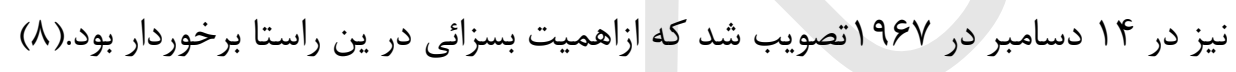

\section{بخش يكم: اسناد بين المللى در مورد مههاجرت:}

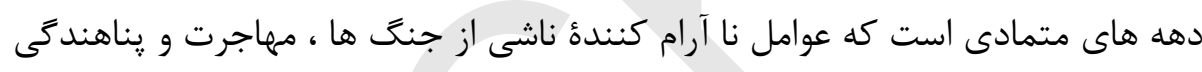

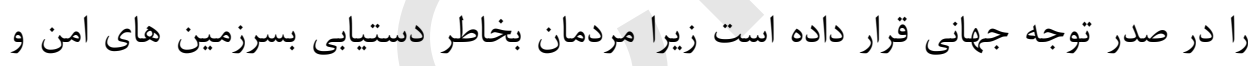

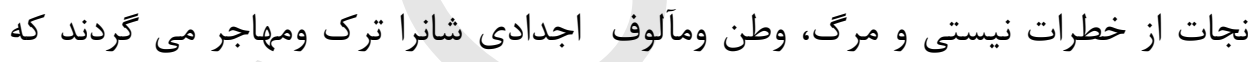

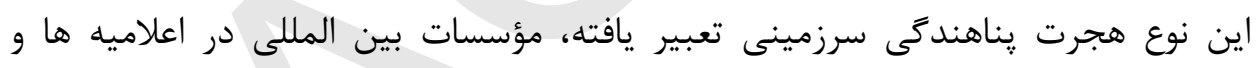

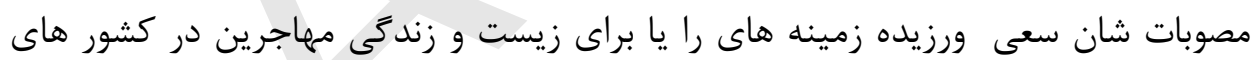

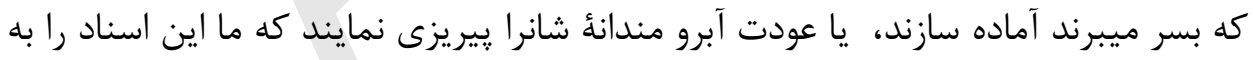

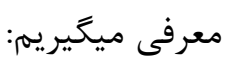

$$
\text { الف: العلامئُ حقور تاريخى اسناد بين المللى مهاجرت: }
$$

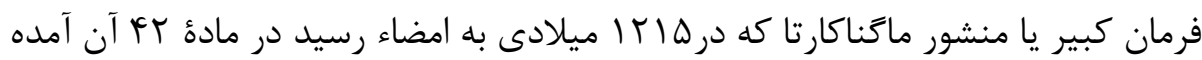


از اين پِ همه بجز آنان كه بموجب قانون مملكت زندانى شده يا از حقوق اجتماعى

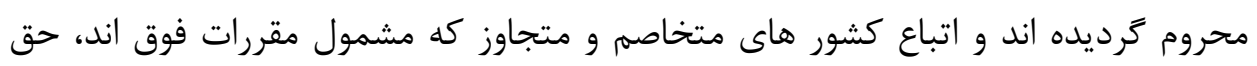
خواهند داشت آزادانه و با امنيت كامل از طريق آب يا خشكى از كشور خارج شوند و مراجعت نمايند مكَر در زمان جنَ كه ممكن است مدت كوتاهى بخاطر مصا لح عمومى از مسافرت خود دارى كنند ولى در هر حال بايد تابعيت خود را محفوظ دارند.(9)

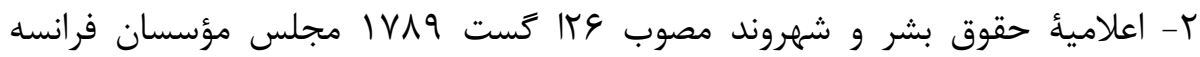

$$
\text { جنين آورده است: }
$$

ماده دوم : هر كس حق دارد هر كشورى و از جمله كشور خود را ترك كند يا به كشور

$$
\text { خود باز زردد. }
$$

$$
\text { ب: اسناد بين المللى معاصر: }
$$

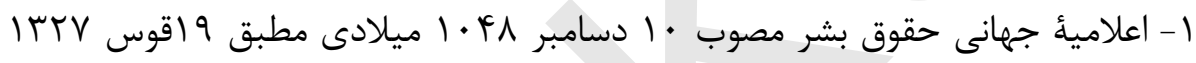

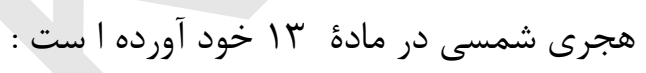

ماده سيزدهم : هر كس حق دارد كه در داخل هر كشورى آزادانه عبور و مرور كند و

$$
\text { محل اقامت خود را انتخاب نمايد. }
$$

(T) هر كس حق دارد هر كشورى از جمله كشور خو د را ترك كند يا به كشور خود باز

ك- اساسنامة سازمان بين المللى مهاجرت

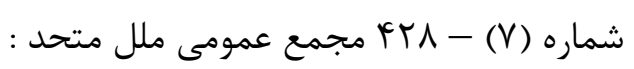

اين اساسنامه تحت عناوين مقررات عمومى در (f) جزء ، وظايف كميشنرى عالى ، امور مالى و تشكيلاتى در (F) جزء تنظيم و نيزتفاوت ها ميان ميثاق رُناهندكان و اساسنامه UNHCR r- قراردادبين المللى رفع هر نوع تبعيض نزادى مصوب الr دسامبر 1990 ميلادى

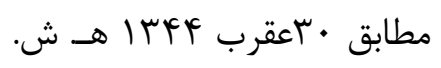


ماده · ا اين قرار داد ، در زمره حق هاى مشتمل بر قرار داد ، بخش( ج) آن حقوق مدنى و سياسى را جنين مد نظر كرفته است:

$$
\begin{aligned}
& 1 \text { - حق رفت و آمد آزاد و انتخاب اقامتكاه در داخل يك كشور . } \\
& \text { r- حق ترك هر كشور منجمله ترك ميهن خود و بازگشت به آن. }
\end{aligned}
$$

F- ميثاق بين المللى حقوق مدنى و سياسى مصوب 19 دسامبر 1999 مجمع عمومى

$$
\text { ملل متحد در ماده ب ا آن آمده است: }
$$

1 - هر كس كه قانوناً در سرزمين دولتى مقيم باشد ، حق عبور و مرور آزادانه و انتخاب آزادانهٔ مسكن خود را در آنجا خواهد داشت.

$$
\text { r- هر كس آزاد است هر كشورى و از جمله كشور خود راد رات آترى كند. }
$$

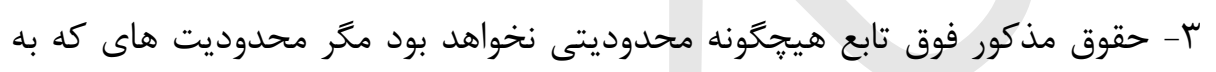

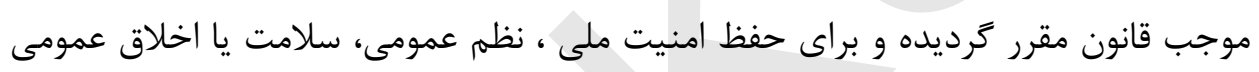
يا حقوق و آزادى هاى ديخران لازم بوده و با ساير حقوق شناخته شده در اين ميثاق، سازگار

F F - هيجكس را نمى توان خود سرانه و بدون مجوز از حق ورود به كشور خود محروم كرد.

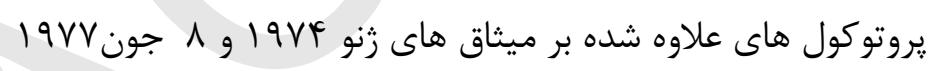
ماده س V مهاجرين و اشخاص بدون تابعيت اشخاصى كه قبل از آغاز مخاصمات تحت اسناد بين المللى قابل قبول به جناح ذيدخل و يا تحت قوانين ملى كشورمهاجر (مهمان) يا كشور محل اقامت به عنوان اشخاص بدون تابعيت يا مهاجر تلقى شده اند ، بايد در تمام احوال و اوضاع بدون هر گونه امتياز و تبعيض با نظر داشت بخش اول و سوم ميثاق جهارم تحت حمايت قرار داده شوند .

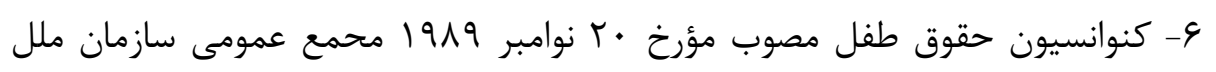


ما ده بيست و دوم: ا - دول طرف كنوانسيون بايد اقدامات لازم را اتخاذ نمايند تا مطمئن شوند طفلى كه در جستجوى يناهندگى است و يا مطابق به قوانين و نظامنامه هاى بين المللى داخلى قابل

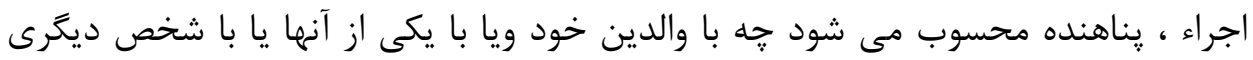

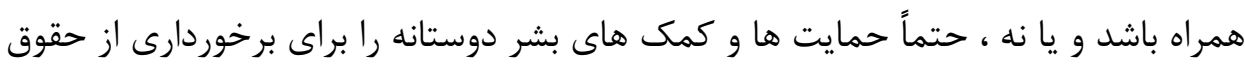
وضع شده در اين كنوانسيون كه دولت ها طرف قرار داد آن هستند ، دريافت مى كنند . r- دول طرف كنوانسيون بايد آنطوريكه مناسب مى بينند با هر نوع تلاشى كه توسط

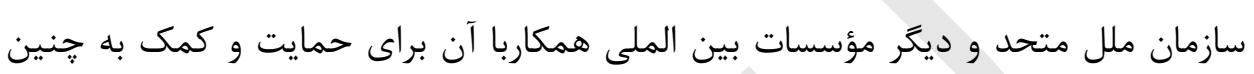
طفلى يا رد يابى والدين و ديكر اعضاى فاميل طفل مهاجر ى كه به اطلاعات لازم براى يكجا شدن با والدين خود نياز دارد ، همكارى نمايد. V- كنوانسيون سازمان بين المللى كار ، مهاجرت جهت استخدام و كاريابى مصوب سال

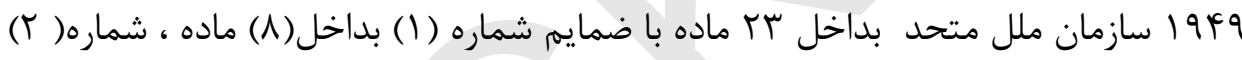
بداخل(r 1 ) ماده و شماره( r) بداخل (1) ماده . (1)

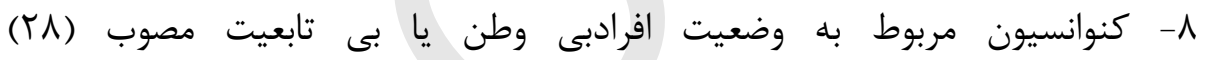
سيتامبر(9DF (19) ملل متحد .

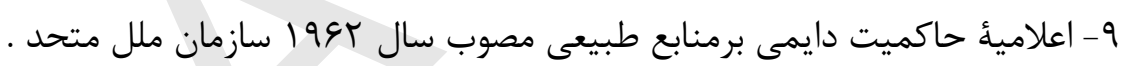
. 1- منشور حقوق و تكاليف كشور ها مصوب سال I9VF . |l - كنوانسيون بين المللى حمايت از حقوق تمام كارگران مهاجر و خانواده آنان مصوب (1) (1999) دسامبر (1) .

rا - موافقت نامه هاى دو ياجند جانبهُ مؤدت تجارتى و سرمايه گذارى ميان كشور ها .

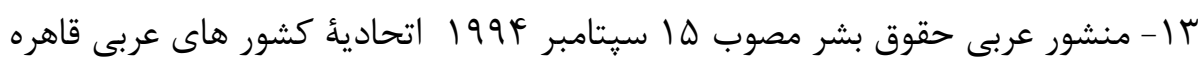

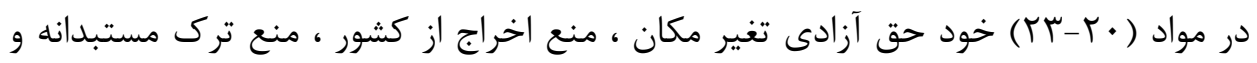
حق تقاضاى يناهندگى سياسى رامد نظر گرفته جنانجه : 
درماده · r آن آمده است: هر باشنده يك كشور داراى حق آزادى تغير مكان و آزادى اختيار مسكن در هر بخش قلمرو كشورش مطابق قانون مى باشد.

\section{بخش دوم: اسناد تقنينى كشور در مورد مهاجرت:}

موضوع مهاجرت در كشور ما ازدير زمانى مورد توجه بوده افغانها در قلمرو ملى و كشور

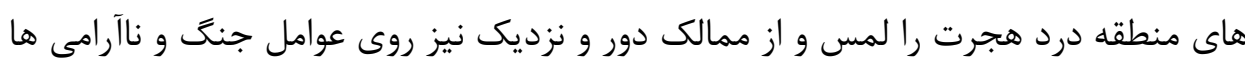

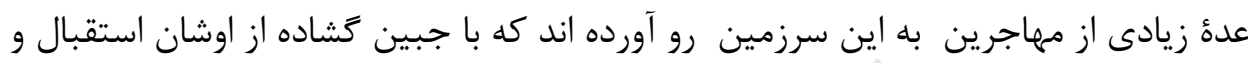

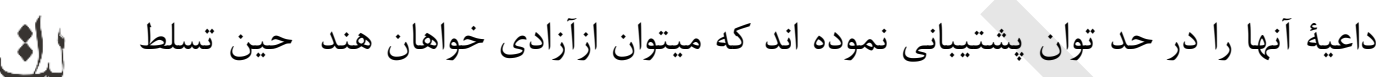

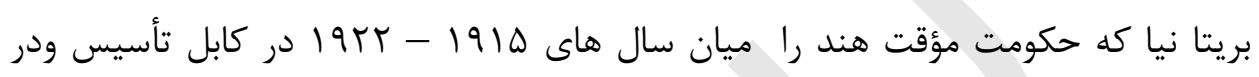
شام اول دسامبر همان سال مهند رايراتا ب بحيث رئيس دولت و مولوى بركت الله بحيث

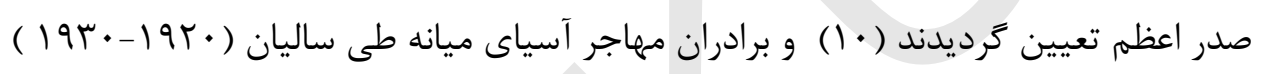
با امير سيد عالم خان پادشاه بخارا كه ملقب به جناب عالى بودند از درياى آمو عبورو به

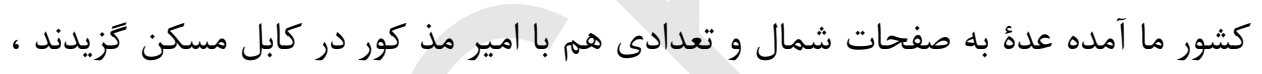

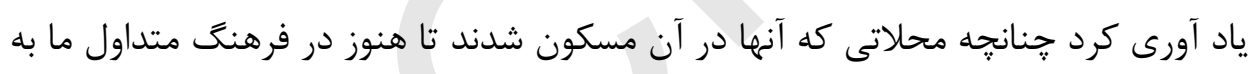
نام قشلاق مهاجرين ياد مى شود.

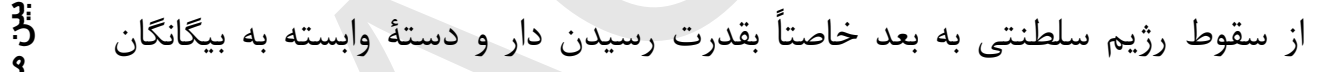

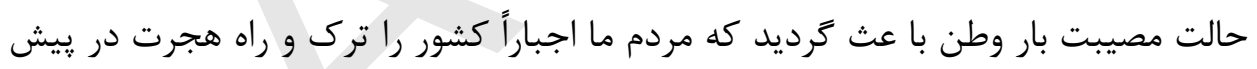
كَيرند تاكنون كه از آن فاجعه هاى مركبار قريب به جهار دهه ميحذرد هنوز هم زن ومرد ،

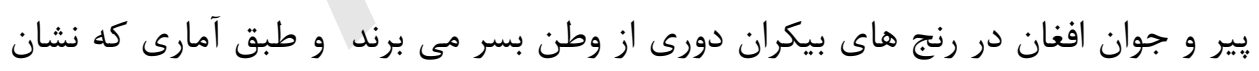
داده شده بالاتر از ينج مليون افغان در كشور هاى آسيائى ، ارويائى و امريكا آواره و بـى وطن بوده جشهم براه و آرمان به دل به صلح وثبات اند تا روزى آبرومندانه با عزت و اطمينان به كشور شان بر خردند . 
بى مورد نيست تا اقدامات قانونمندانهُ را كه در اين عرصه از آغاز تا كنون صورت كرفته و حكومت هاى وقت جهت تنظيم امور مهاجرت اسناد تقنينى را وضع و طى مراحل نموده

$$
\text { اند برشمرد : }
$$

\section{الف: اسناد تقنينى قبل از ادارهُ مؤقت:}

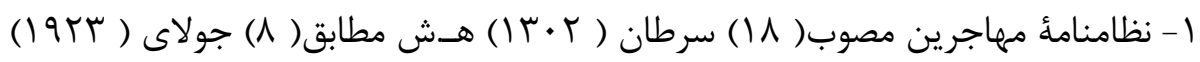
ميلادى كه به زبان هاى درى و يشتو در مطبعأ دايره تحريرات مجلس عالى وزراء به طبع

$$
\text { رسيده است . }
$$

اين نظامنامه كه شاه امان الله خان آنرا توشيح نموده در سه عنوان ، صورت قبول مهاجرين ، وظايف و صورت اسكان مهاجرين بداخل r r ماده تنظيم يافته ونخستين سندى مى باشد كه وضع مهاجرين را بررسى ، حقوق ، وظايف و تكاليف شان و همجنين اداراتى را كه به حال مهاجران رسيدگى مى نموده به معرفى گرفته است .

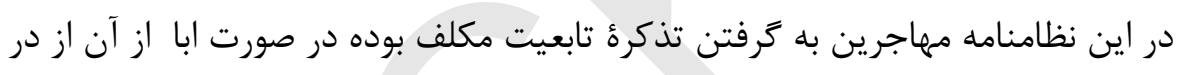
يافت حقوق مهاجرت محروم مى شدند . جهت اسكان مهاجرين محل مناسب تعيين و

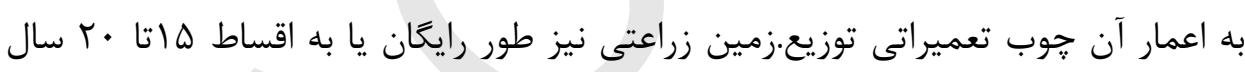
براى شان داده مى شد ، مهاجرين الى شش سال از خدمت عسكرى و تا سه سال از يرداخت ماليات معاف بوده اند تسهيلات صحى و تعليمى براى خود و خانواده شان فراهم و وزارت داخله از امورمربوط به مهاجرين رسيدكى مى نموده است.

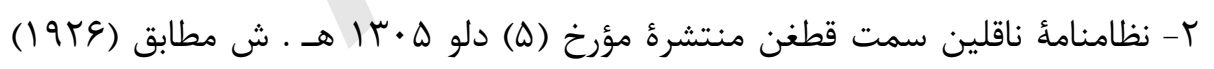
ميلادى كه اين نظامنامه در مطبعهُ شركت رفيق به طبع رسيده است . اين سند كه بداخل (Y I) ماده بوده امور مربوط به بيجا شدكان (ناقلين) در داخل كشور

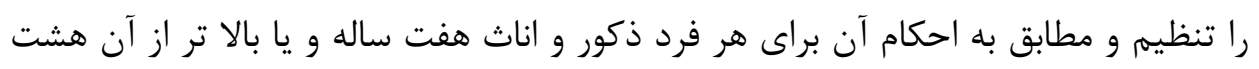

$$
\text { جريب زمين آبى به قيمت فى جريب يك شاهى ازجانب حكومت توزيع مى كرديد . }
$$


به منظور مساعدت ناقل براى كشت هر جريب مقدار جهارسير كندم وجو به ضمانت داده مى شد و يس از سه سال قيمت آن اخذ مى گرديد ، جهت خريدارى قلبه و ساير لوازم

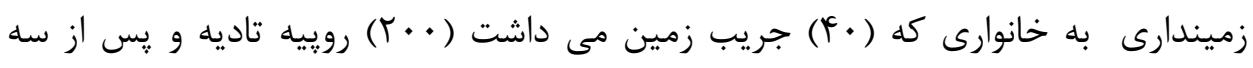

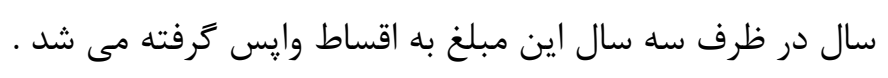
در اين نظامنامه معافيت هاى الى شش سال مد نظر خرفته شده بود .

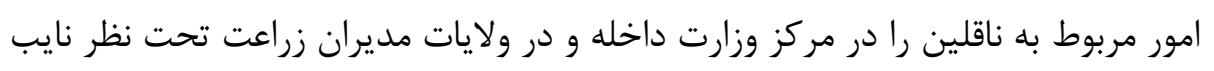
الحكومه ها و حكام اعلى تنظيم مى نمودند و مناطقى كه ضرورت به حفر انهار ميداشت ، وزارت تجارت مكلف بود تا زمينهُ آماده ساختن تخصيصات لازمه را فراهم نمايد . ساليان متمادى اين نظامنامه مرعى بوده سند ديخرى جاى آنرا نخرفت اما انطوريكه در

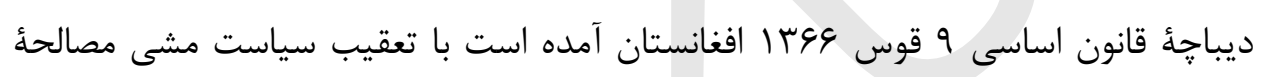
ملى براى دستيابى به مصالحه و تحكيم وحدت ملى روش انساندوستانه را اعلام و در مواد

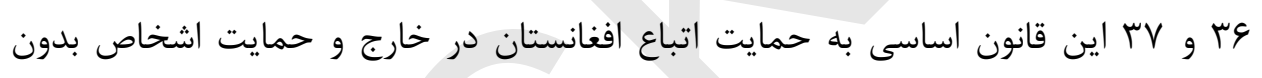

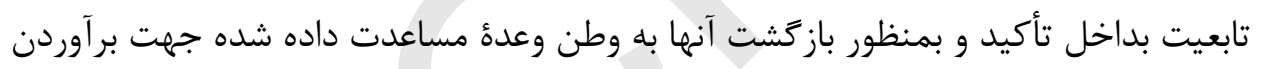

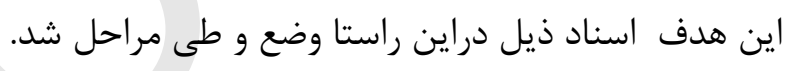

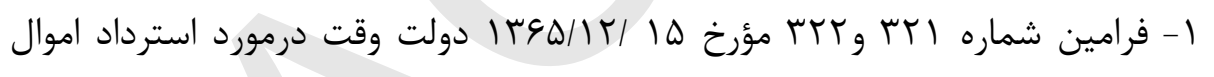

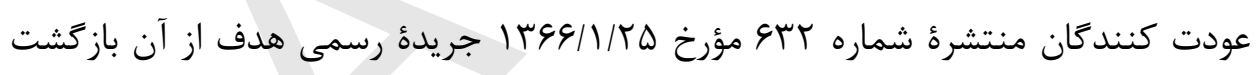

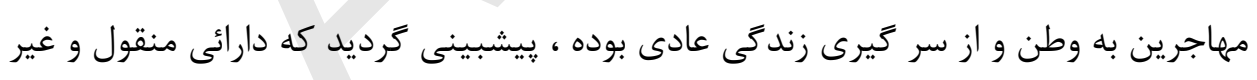

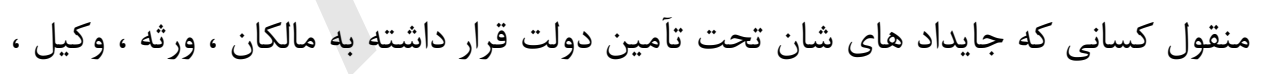

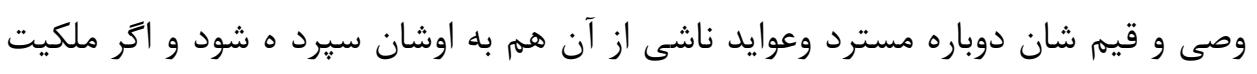

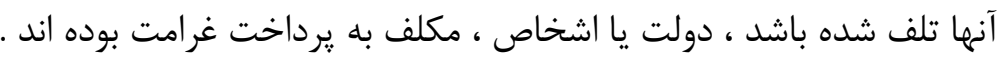

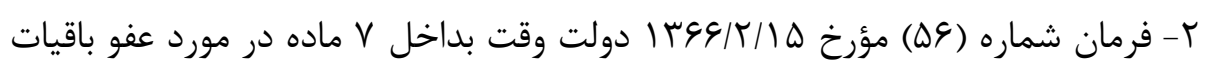
صرفيةٔ برق ، تكس اماكن ، محصول صفايى آب وغيره عودت كنند

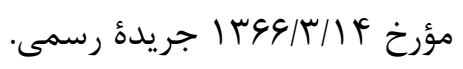


اين فرمان به اساس مشى مصالحهٔ ملى صادر و هر گاه مراجع ذيربط امور عودت

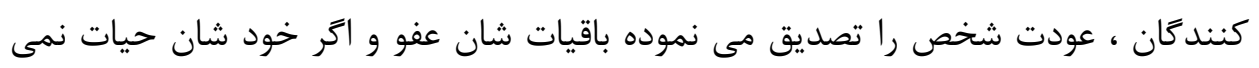

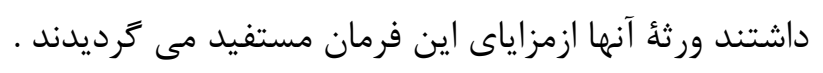

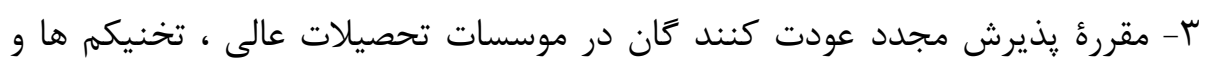

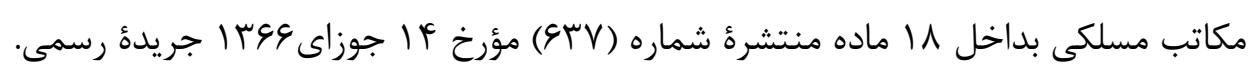
هدف از آن فراهم نمودن تسهيلات براى يذيرش مجدد محصلان و متعلمان كه تحت

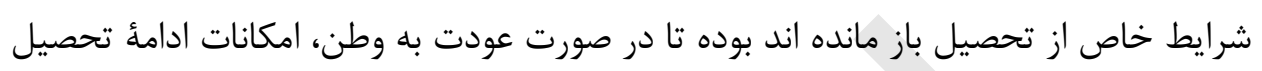
براى شان آماده گردد.

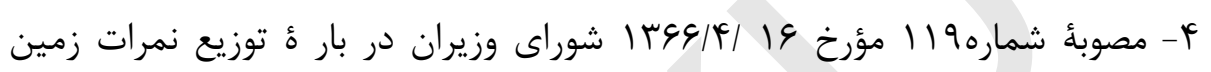
براى عودت كنند

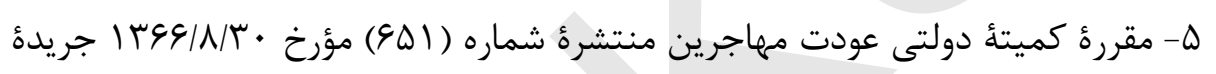

اين مقرره بداخل سه فصل و 19 ماده بوده تشكيل كميتؤ دولتى عودت مهاجرين با وظايف و صلاحيت هاى آن توأم با ايجاد نمايندگى ها در ولايات ييشبينى و تنظيم گرديده است و با اين اقدام اولين هستهٔ وزارت مهاجرين و عودت كنندكان كذاشته شد ـائ ـاين كميته وظيفه كرفت تا كليه مسايل مربوط به عودت كنندكان اعم از مواد غذايى ، مسكن ، حل

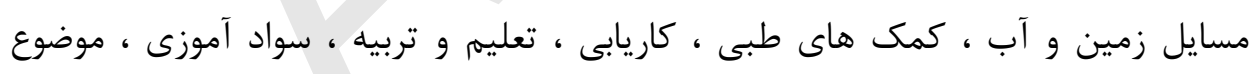
خدمت عسكرى وساير مسايل اجتماعى و اقتصادى مربوط به مهاجرين را بررسى نمايد .

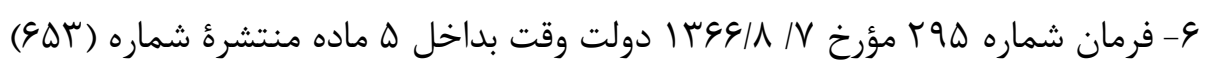
مؤرخ ا

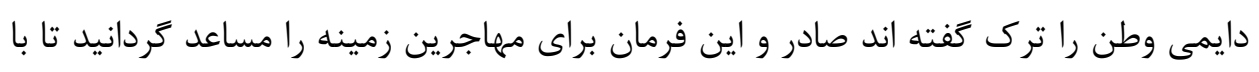

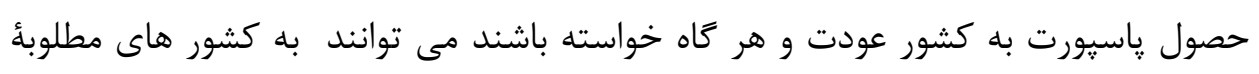

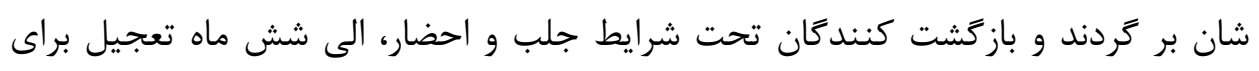
شان وعده داده شده بود. 
V- فرمان شماره (1) كنندكان كه اسلحه ، مهمات ، تجهيزات و ساير عينيات عسكرى ذمت شان بوده از تعقيب

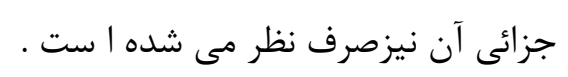

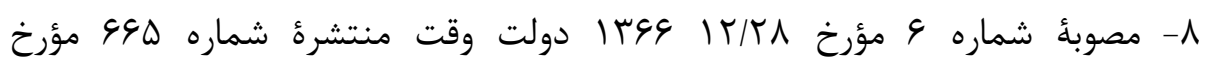
ه ه عودت كنند

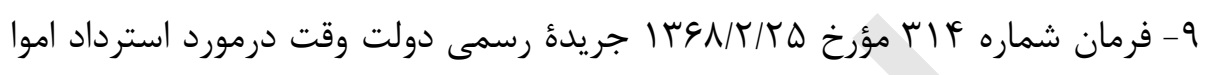

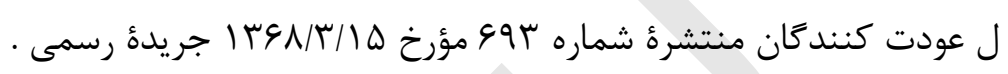

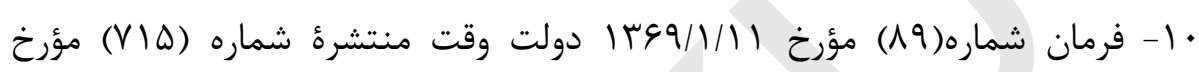

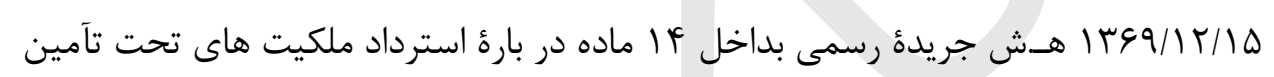

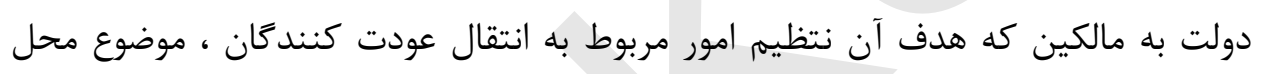

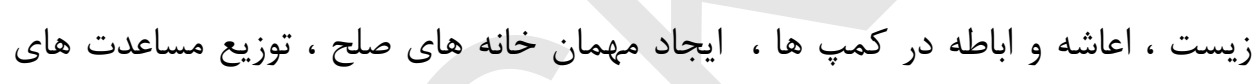

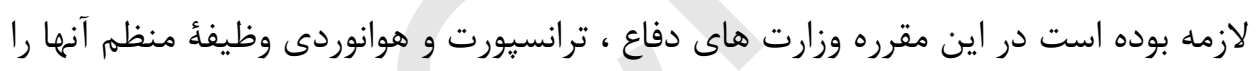

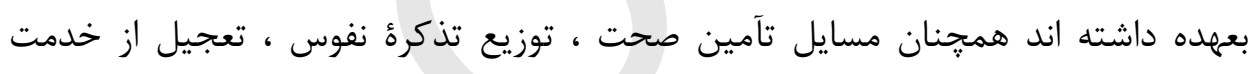

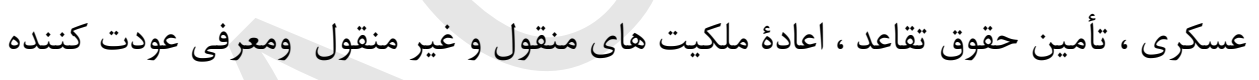

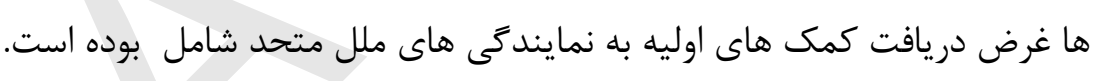

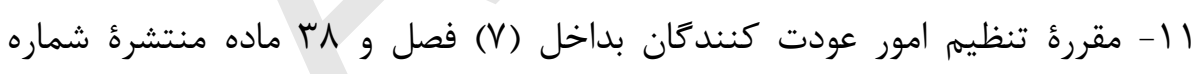

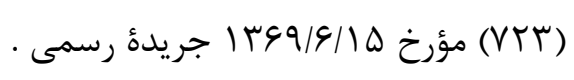

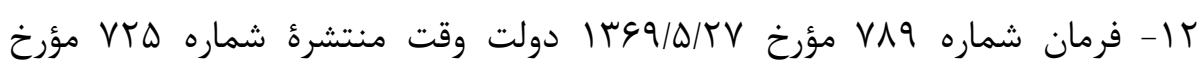

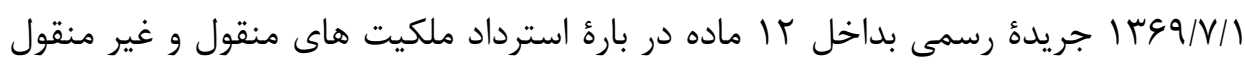
عودت كنند rا - جزء (r) ماده (YY) قانون اصول عمده تشكيل وظايف وزارت ها و ادارات دولت

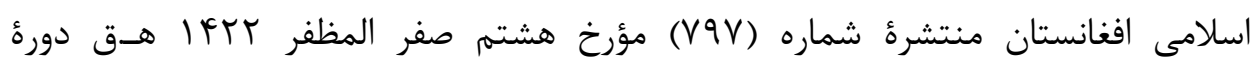

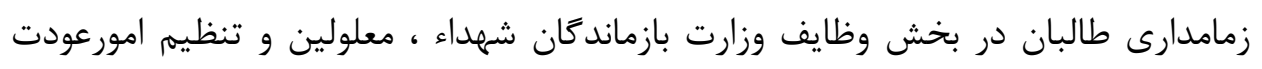


مهاجرين جكمى را بيش بينى نموده است تا جهت انتقال مهاجرين عودت كننده به كشور،

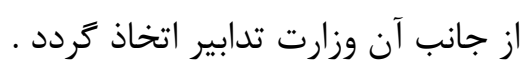

fl أ- فرمان شوراى جهادى دولت اسلامى افغانستان در مورد تثبيت حقوق و يذيرش

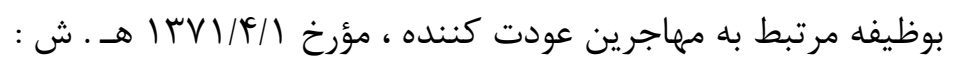

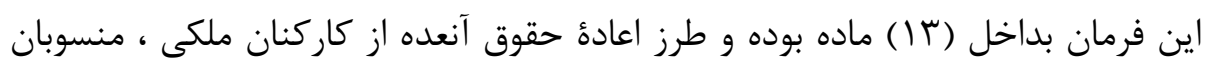

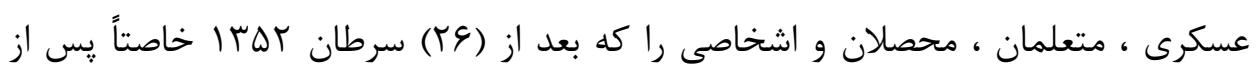

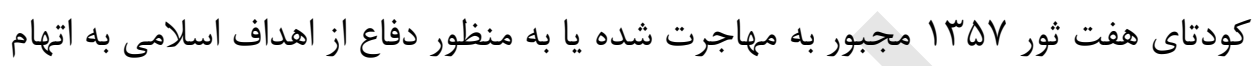

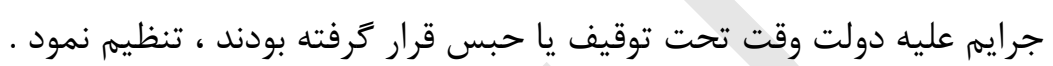

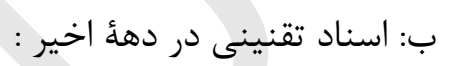

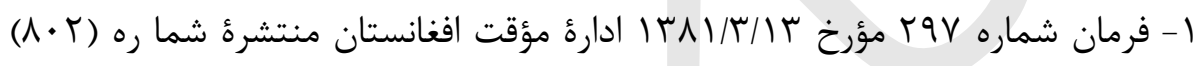

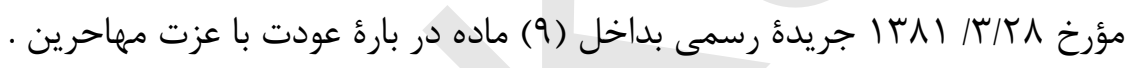

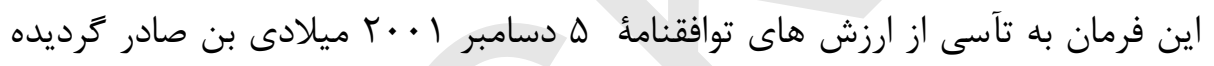

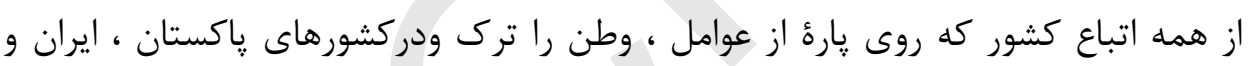

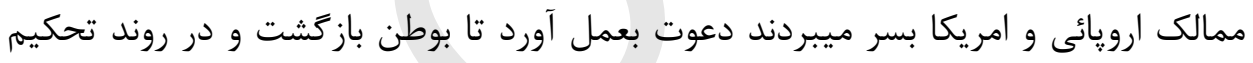

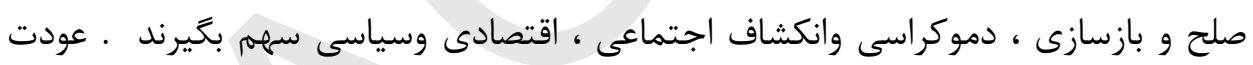

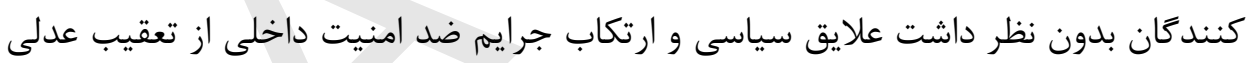

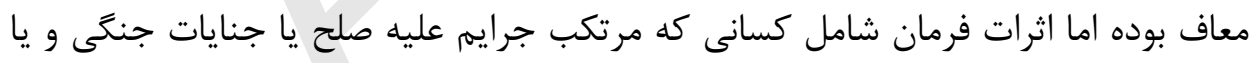

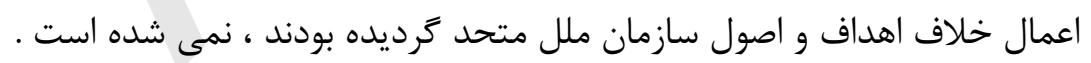

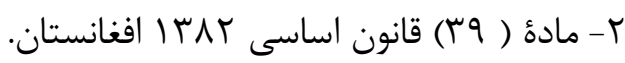
هر افغان حق دارد به هر نقطؤ كشور سفر نما يد و مسكن اختيار كند مكر در مناطقى المانى كه قانون ممنوع قرار داده است. هر افغان حق دارد مطابق احكام قانون به خارج افغانستان سفر نمايد و به آن عودت كند. 


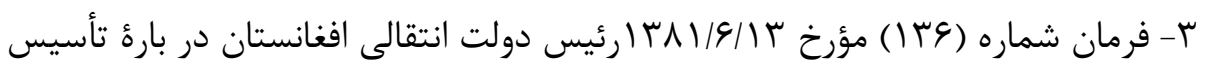

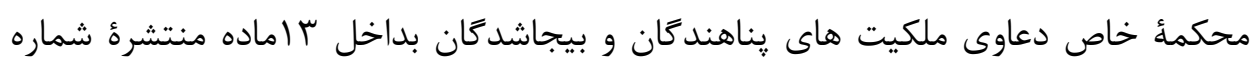

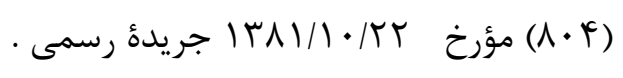

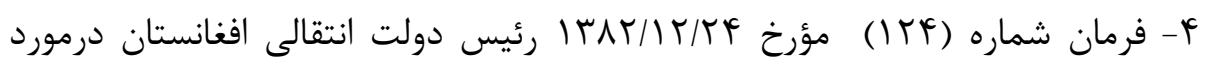

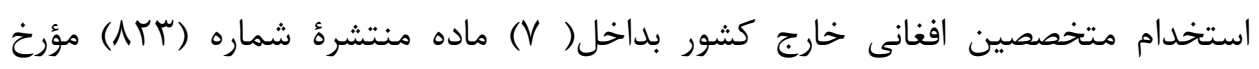

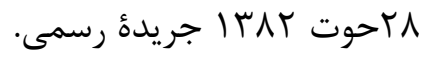

بموجب اين فرمان متخصصين افغانى خارج از كشور امكانات عودت به وطن و استخدام مجدد در وزارت ها و ادارات جهت سهمعيرى بخدمت كشور را يافتند.

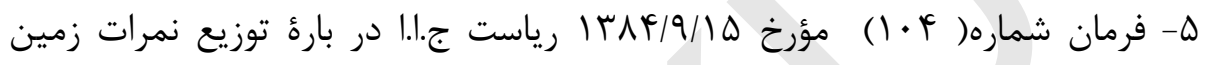

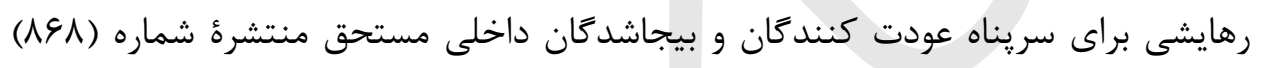

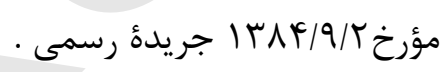

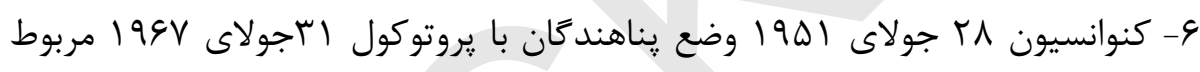

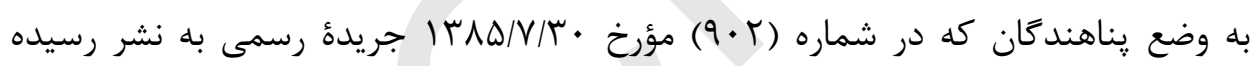

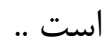
مأخذ

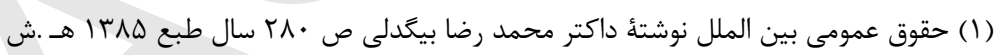

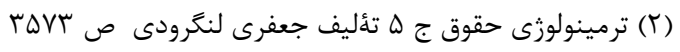

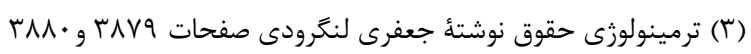

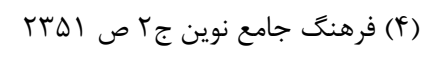

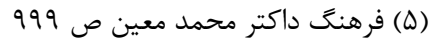

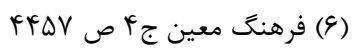

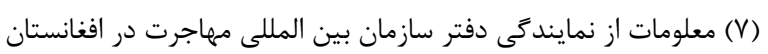

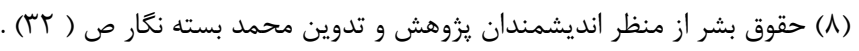

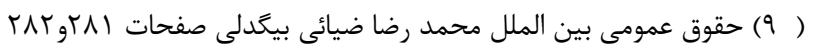

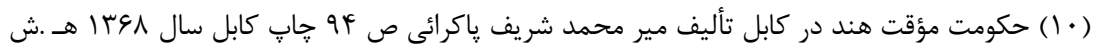




\section{اسلامي تولنه او د بنحُو د رياست دولت دنده

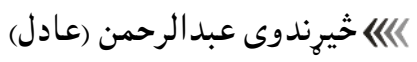

بده به نه وى كه دا خبره راياده كرو جى اسلام دين او دولت دى ، يا په بل عبارت سره اسلام دين

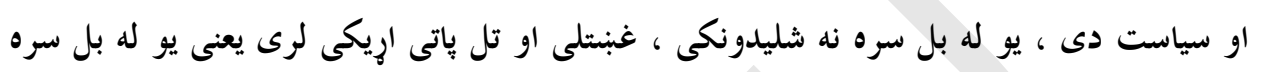

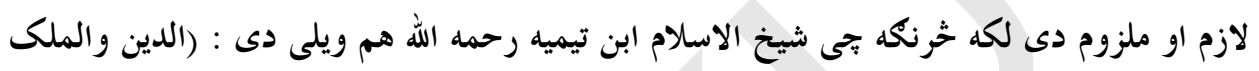

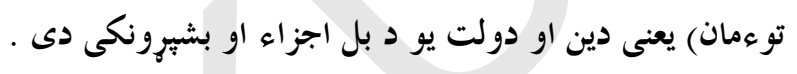

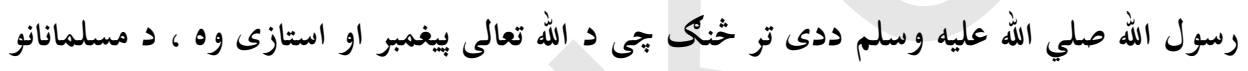

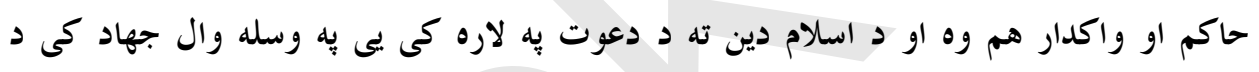

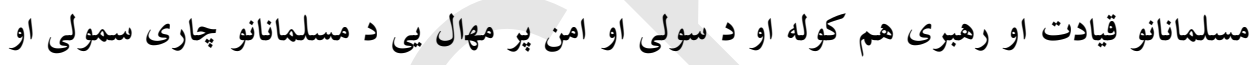

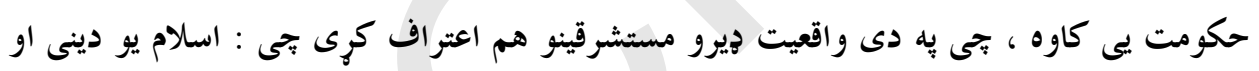
سياسى نظام دى حكهه ددى نظام موسس او بنسب اينبو دونكى بيغبر صلي الله عليه وسلم سياست

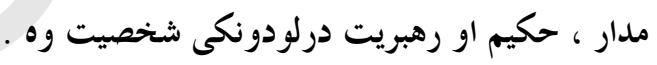

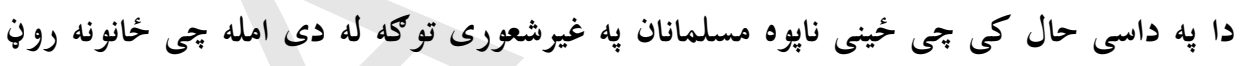

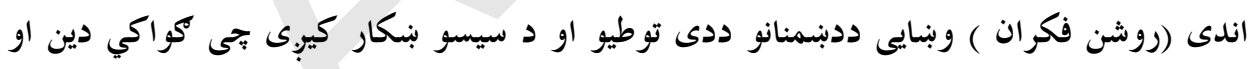

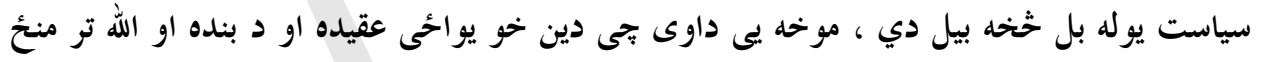

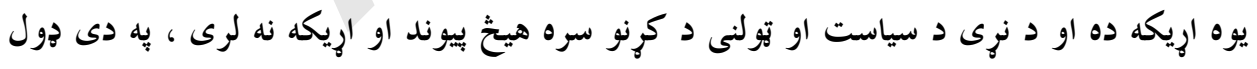

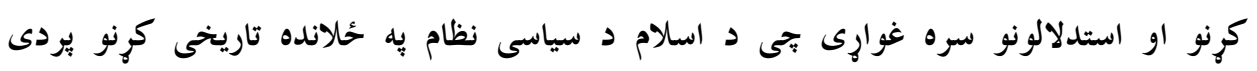

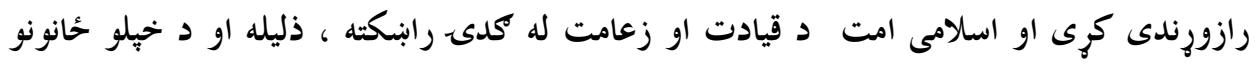

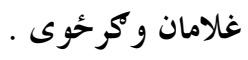

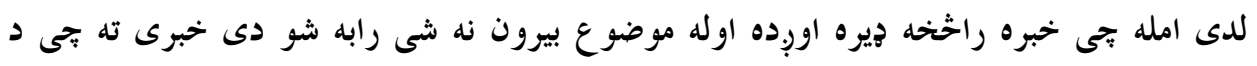

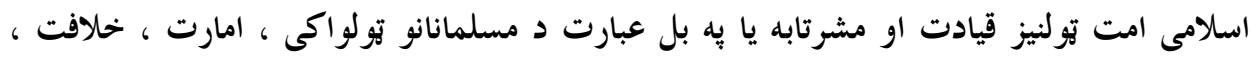

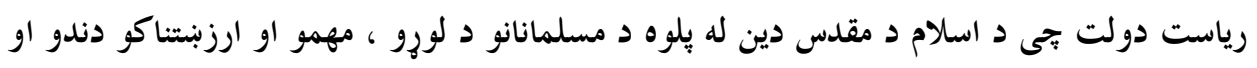


مسوليتونو خخه شميرل كيبرى ، ايا د اسلام د مقدس دين له نظره ددغه دروند مسوليت او دندي تر

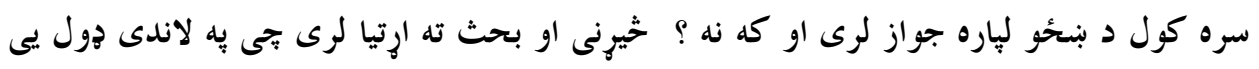
يادونه وربولم قيادت او واكمنى به دوه دوله ده : بادولم

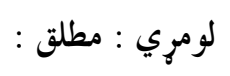

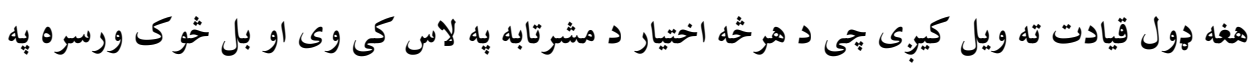

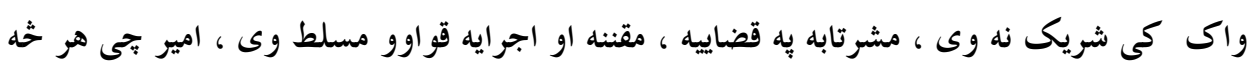

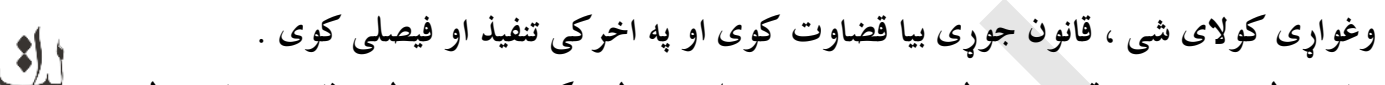

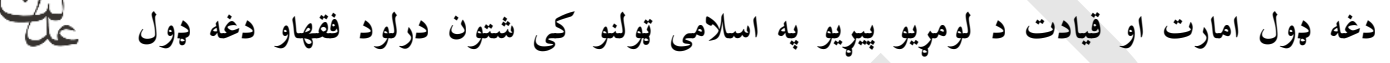

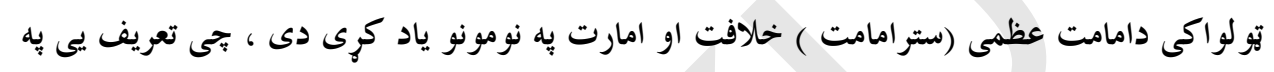

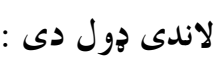

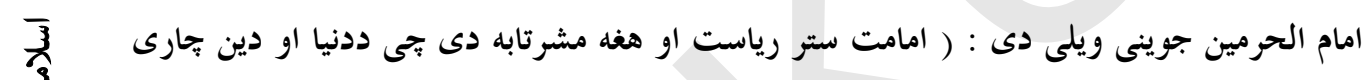

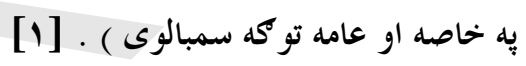

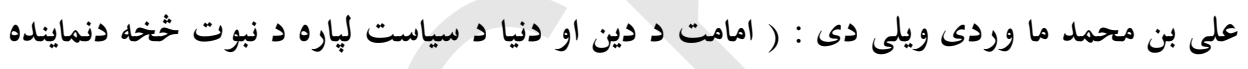

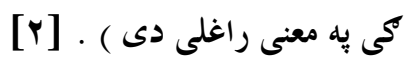

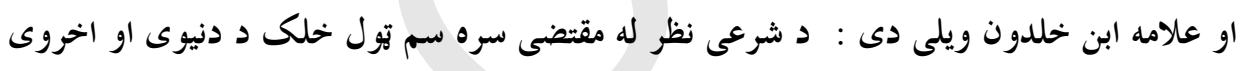

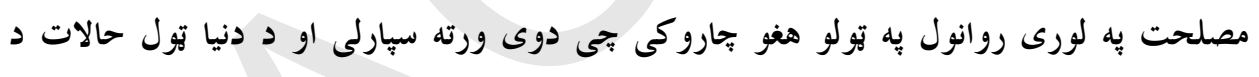

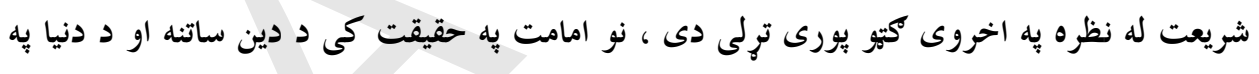

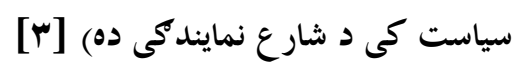

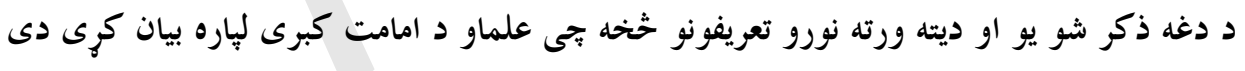

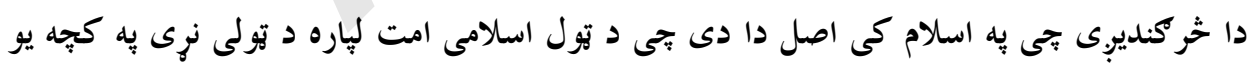

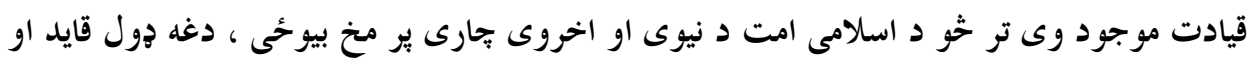

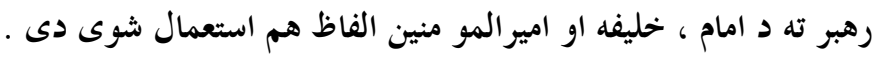

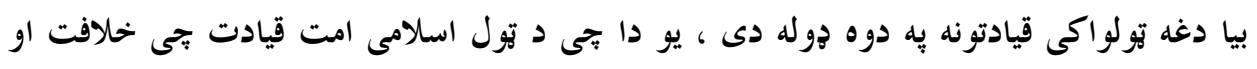

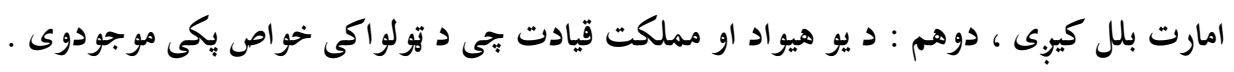


به دى دول قيادت كى واكى به مختلفو برخو ويشل شوى وى ، يوه برخه واك له يارلمان (شورا)

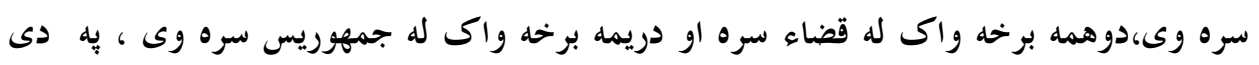

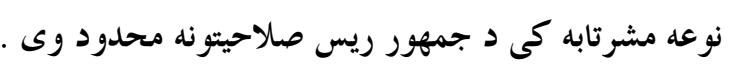

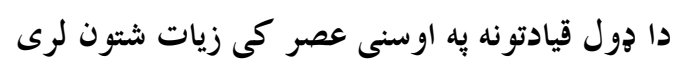

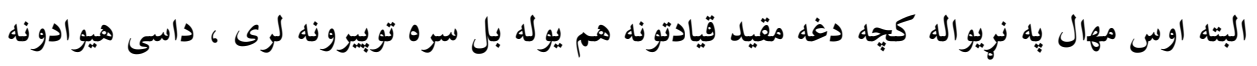

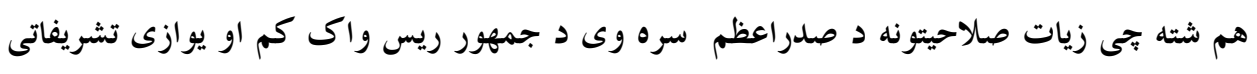

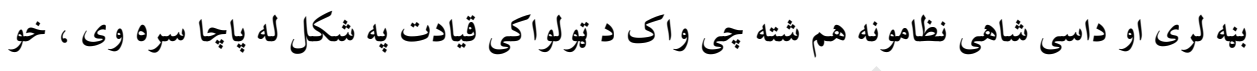

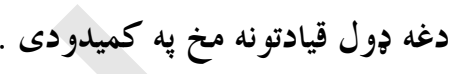

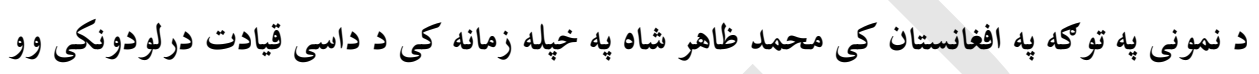

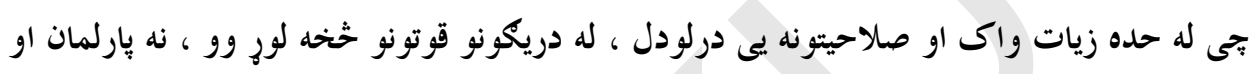

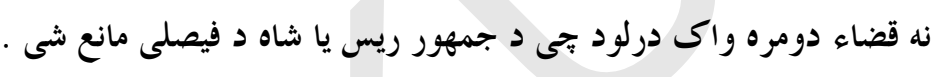

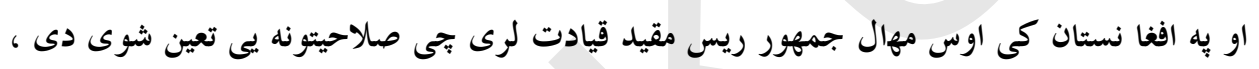

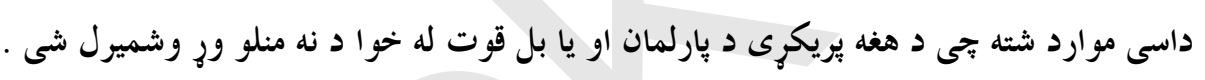

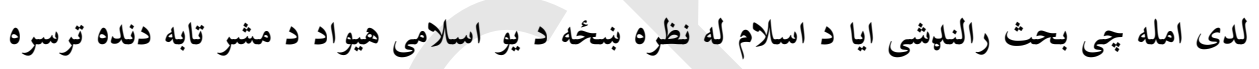

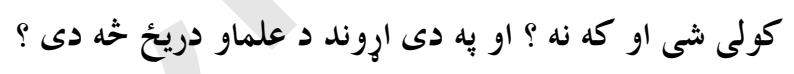

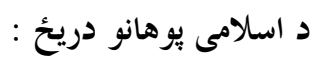

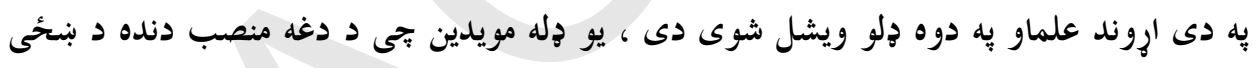

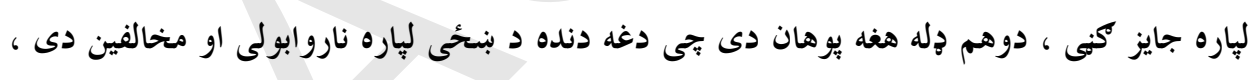

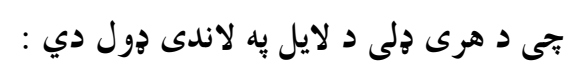

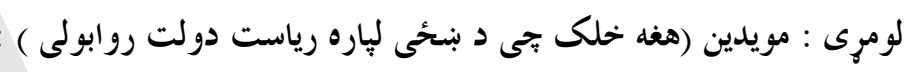

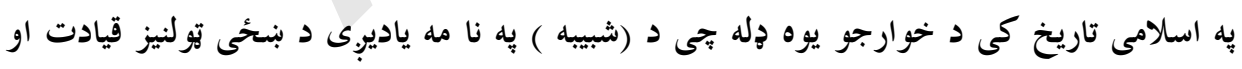

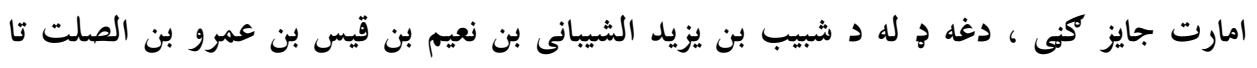

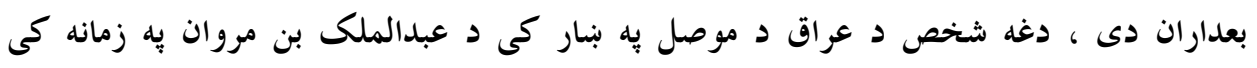

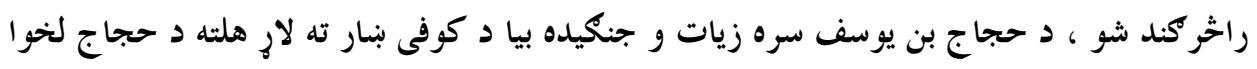

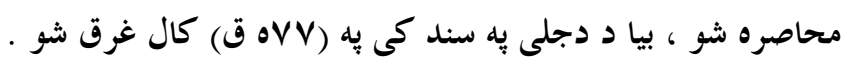

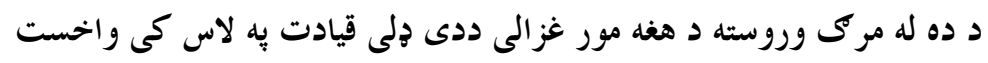




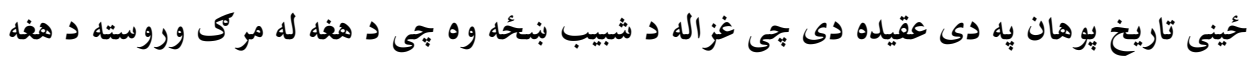

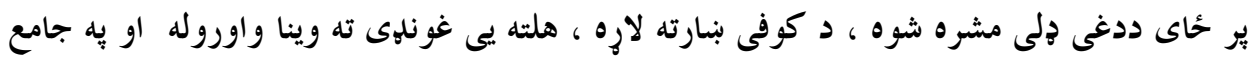

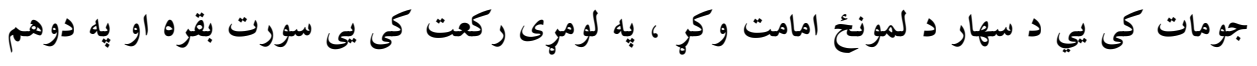

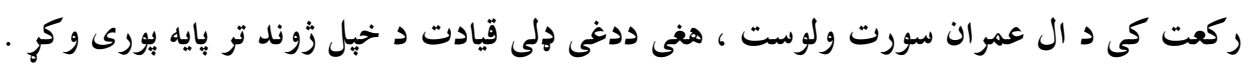

همدا دول دا هل تشيع يوه ذوله هم د بنحُى اما مت درست كنى او فاطمه د جعفر خورد خهيلو

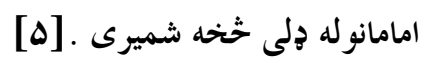

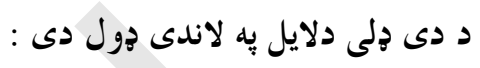

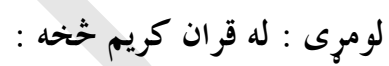

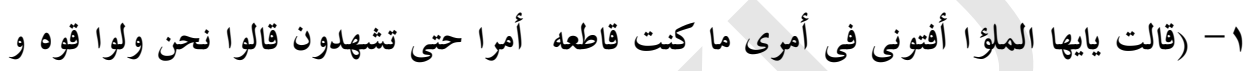

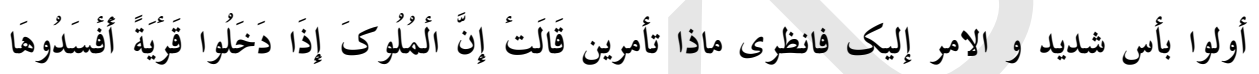

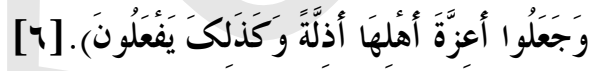

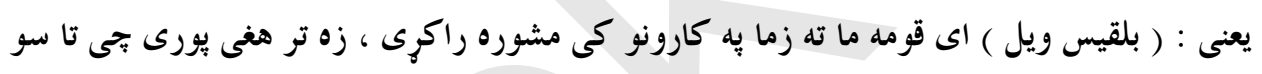

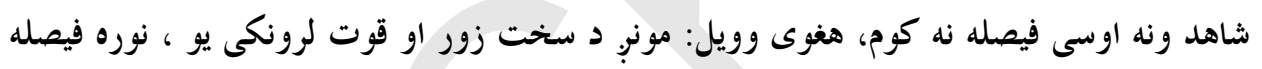

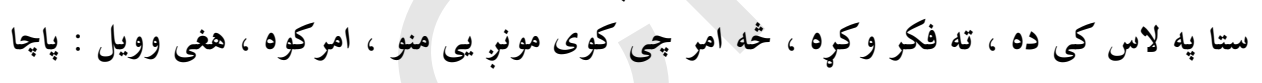

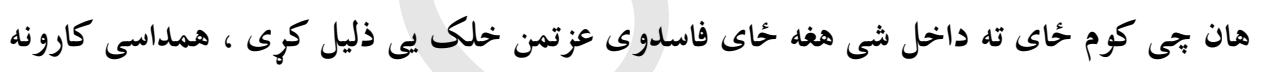

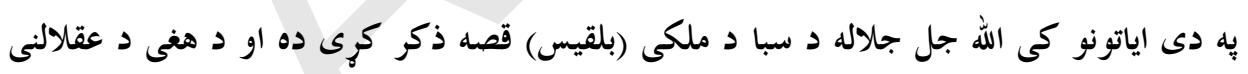

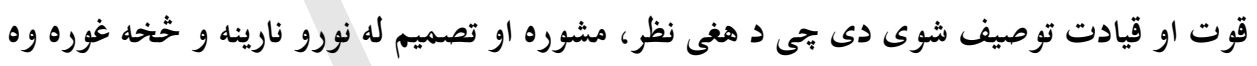

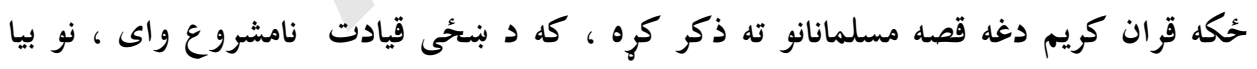
هماغه بنه موقع وه جّى الله ورته اشاره كرى وائى دئ.

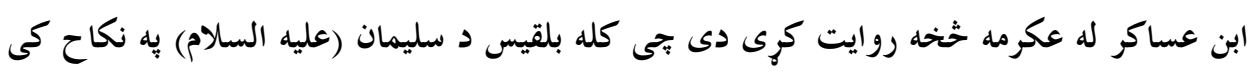

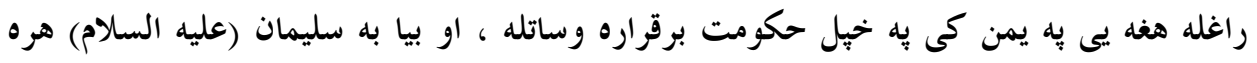

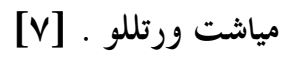
د يورتنى استدلال حُو اب: 


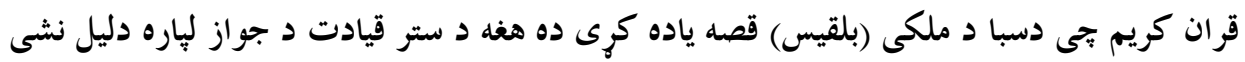

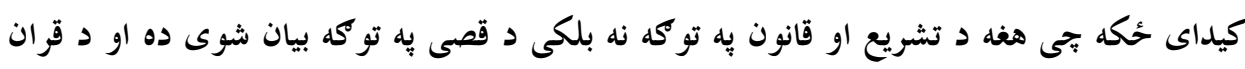

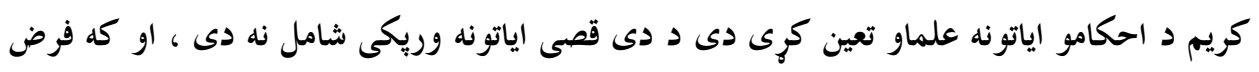

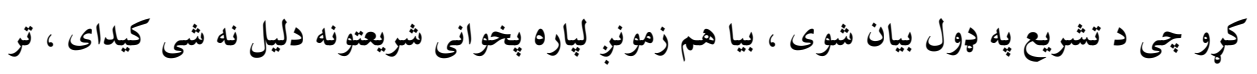

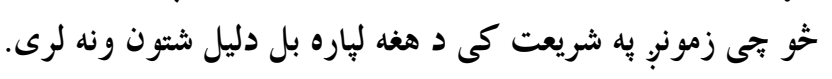

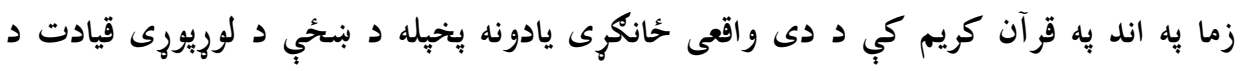

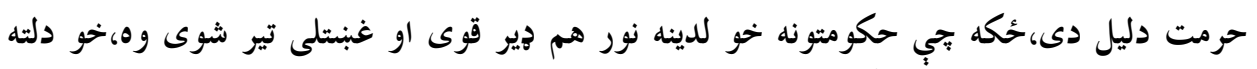

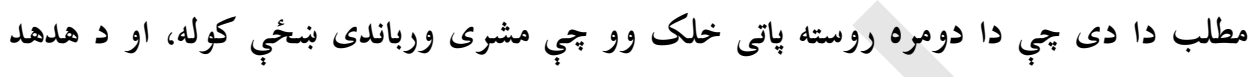

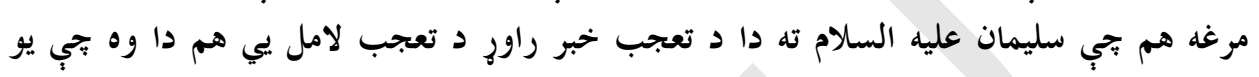

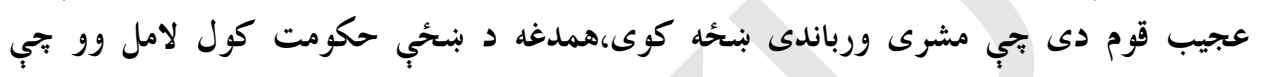

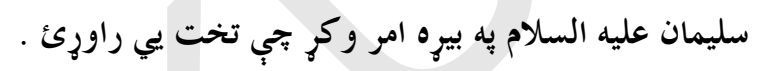

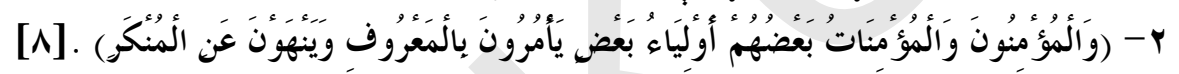

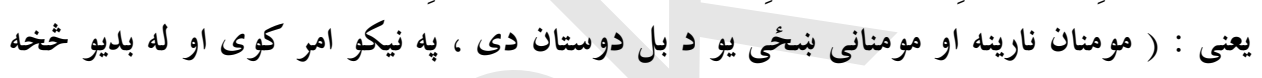
م استد كول كوى ) :

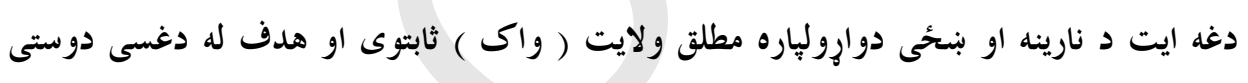

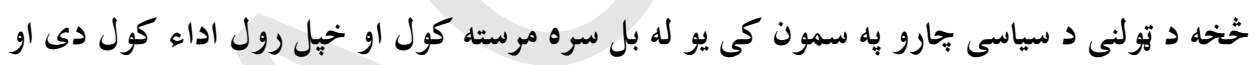

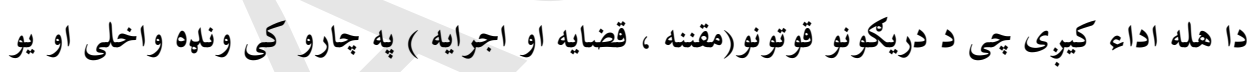

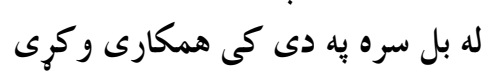

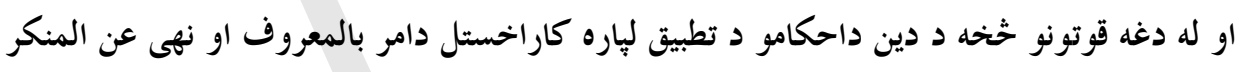

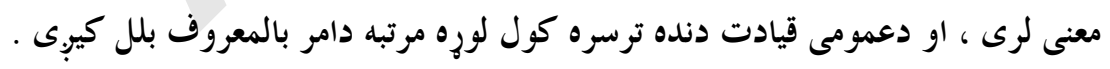

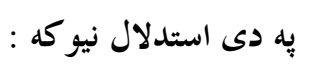

(6)

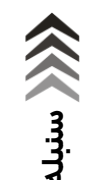

د امر بالممعروف او نهى عن المنكر ولايت (واكى) ددى معنى نه لرى جهى بنحخه او نارينه بٍه تولو

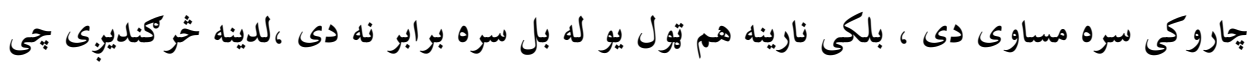

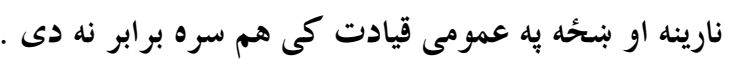




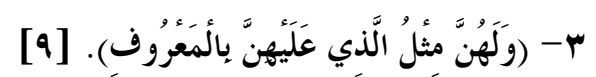

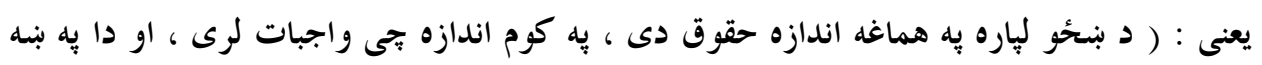

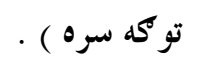

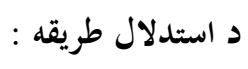

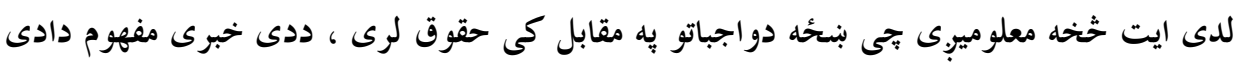

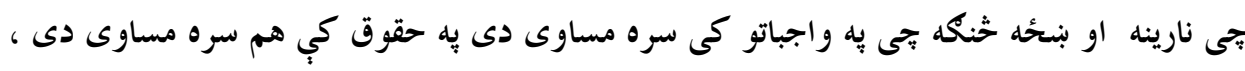

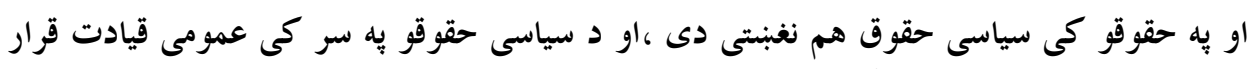

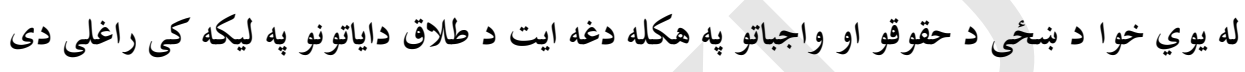

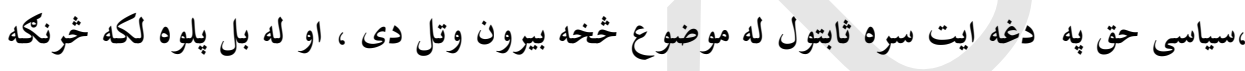

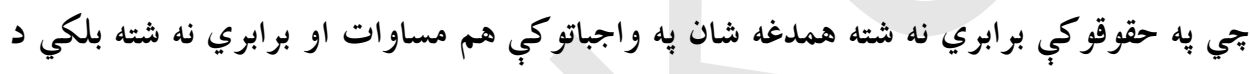

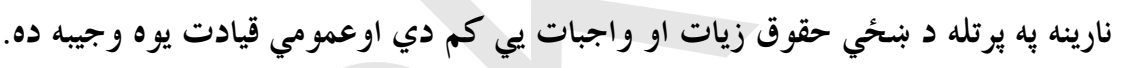
دوهم : له نبوى حديثونو خخه :

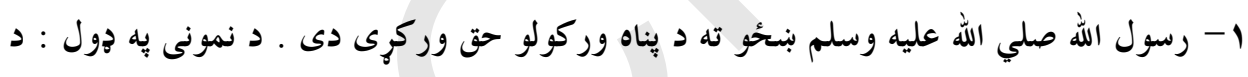

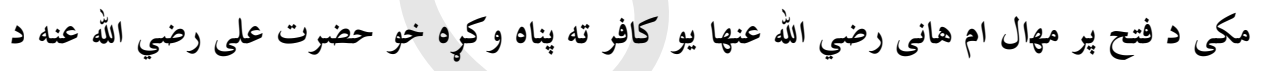

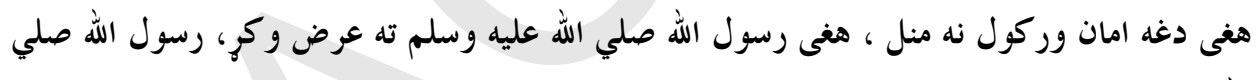

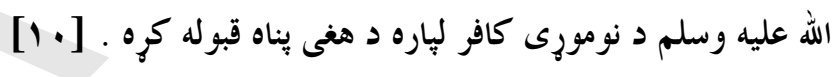

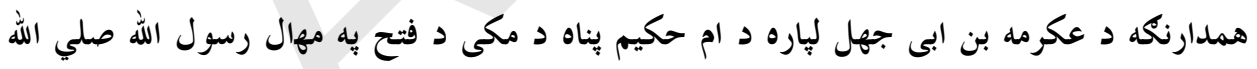

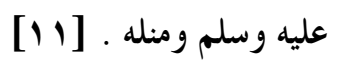
د د استدلال طريقه :

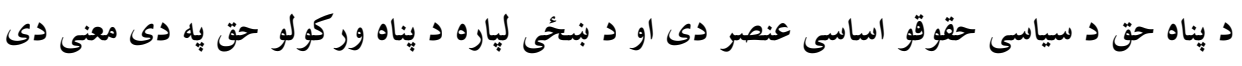

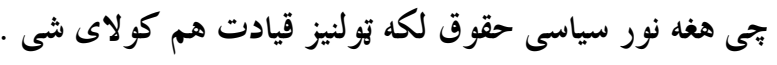
به دي استدلال نيو كه :

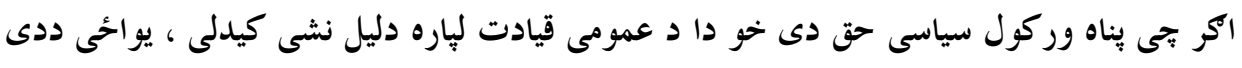

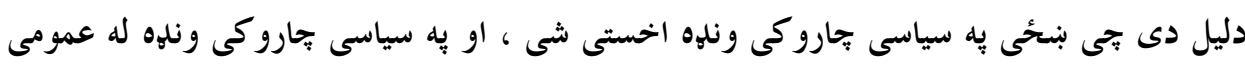

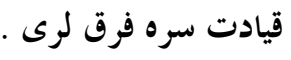


ب- د بنحُو بيعت د رسول الله صلي الله عليه وسلم سره به دى مفهموم دى تحى له اسلام او بيغمبر

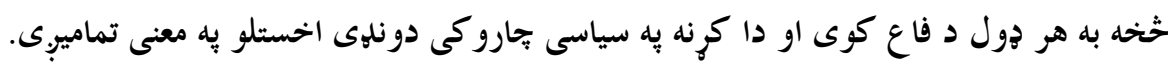

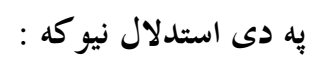

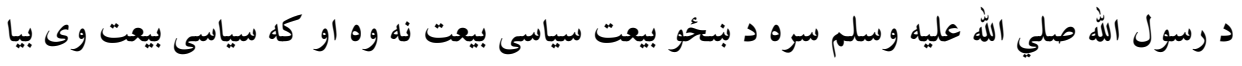

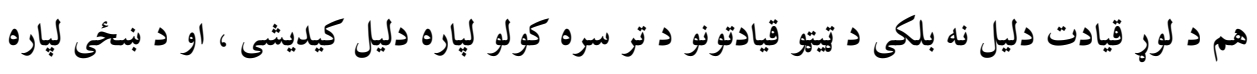

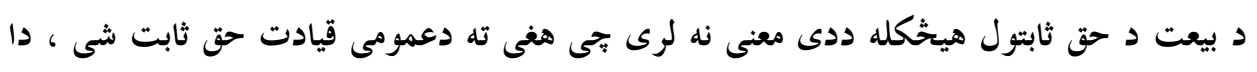

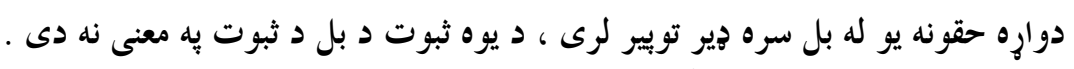

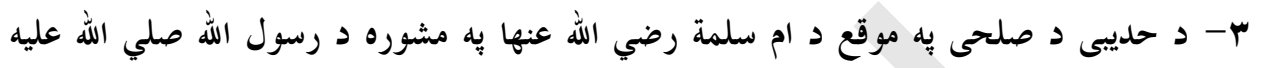

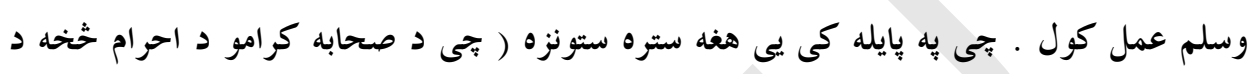

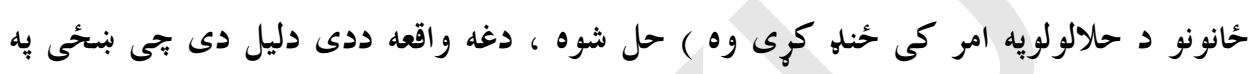

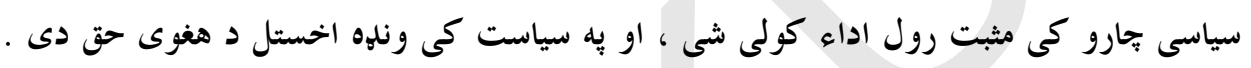

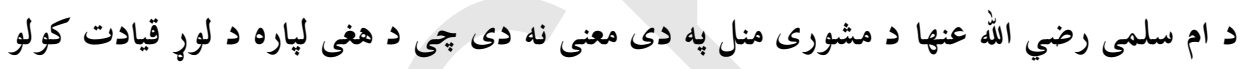

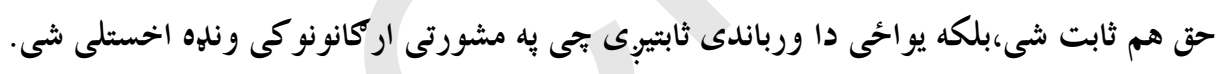
دريم : له اسلامى تاريخ خخه :

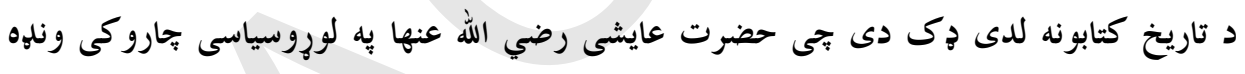

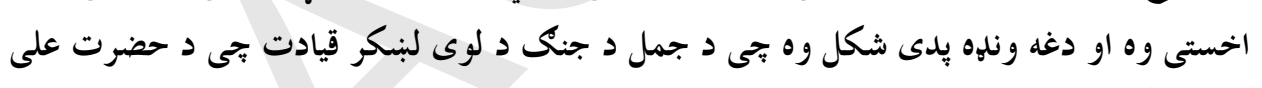

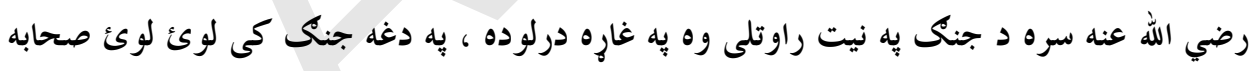

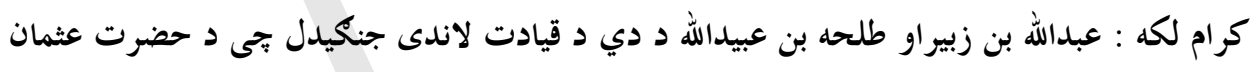

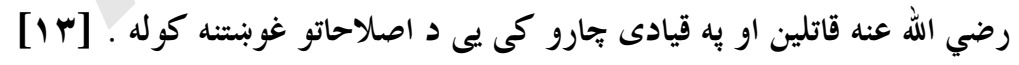

يه دى تاريخى واقعه كى حضرت عايشى رضي الله عنها د دغه لوى لبنكر داسى قيادت يه غاره

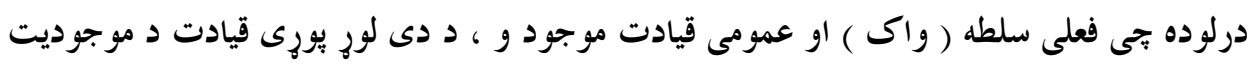

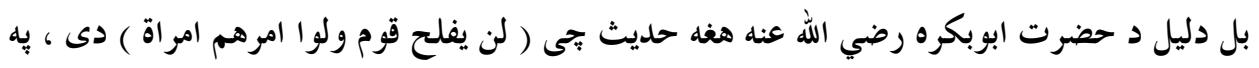

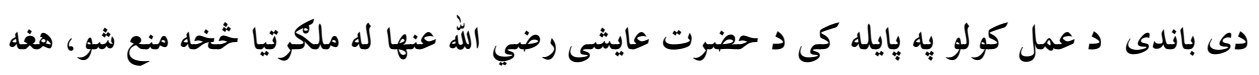


د عايشى رضي الله عنها واك ليدلى وه بحى عمومى قيادت وه بحى د ذكر شوى حديث خه مخالفت

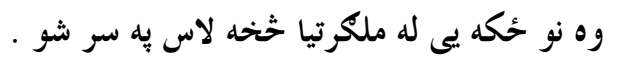

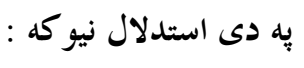

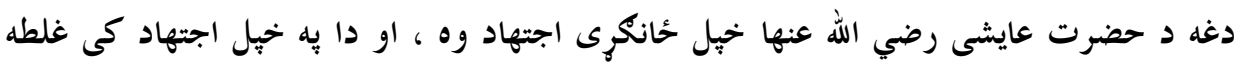

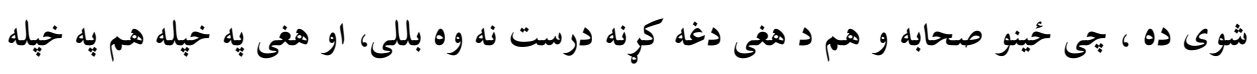

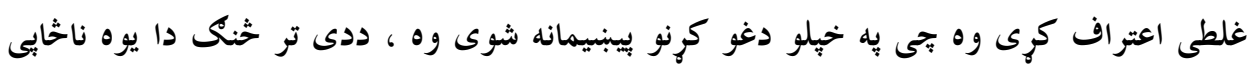

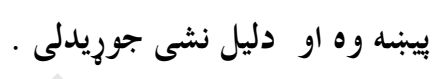

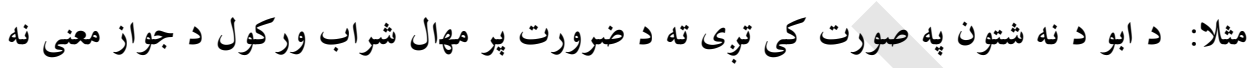

دوهم : مخالفين (هغه يوهان بحى د اسلام له نظره د بنحخى رياست دولت ناروا بولى ) :

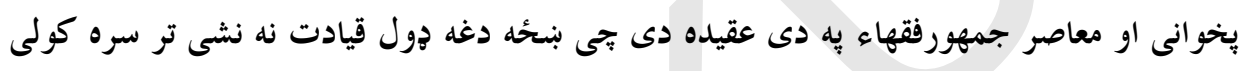

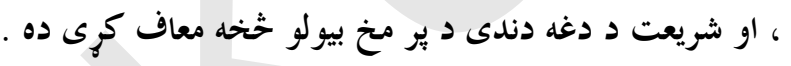

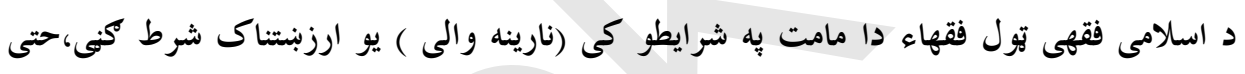

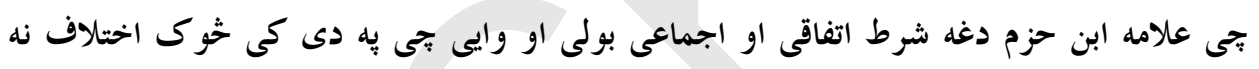
لرى.

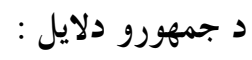

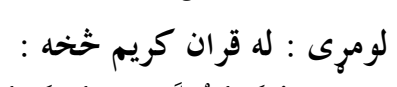

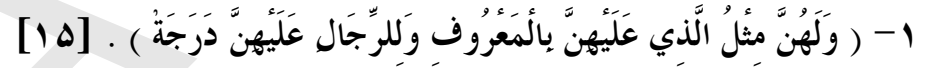

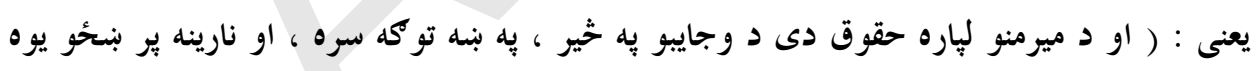

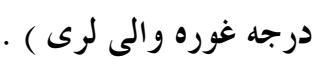

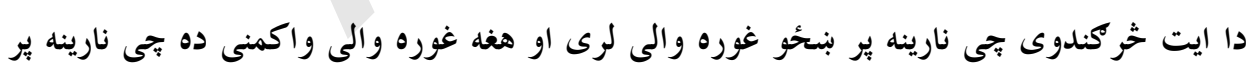

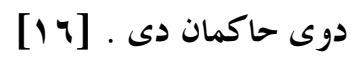

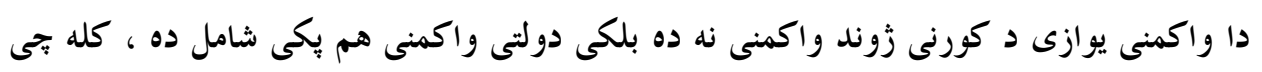

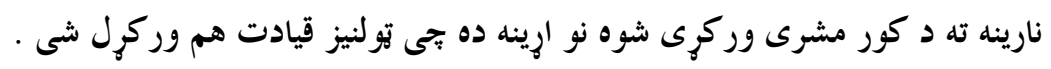

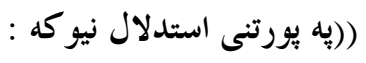

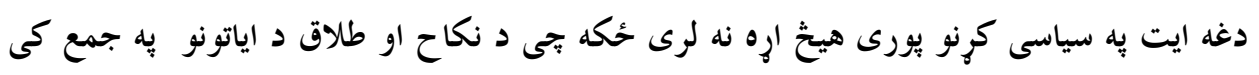

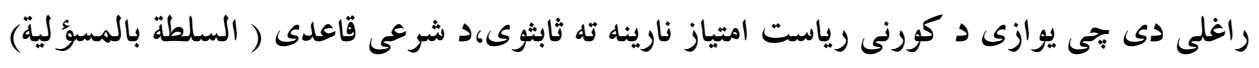




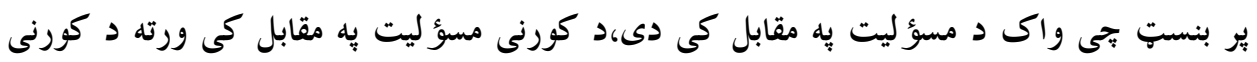

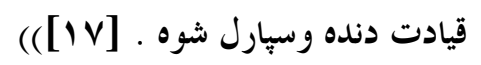

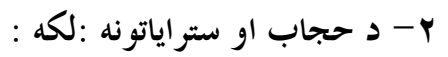

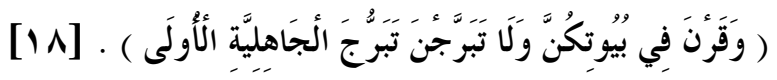

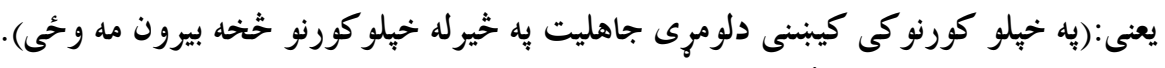

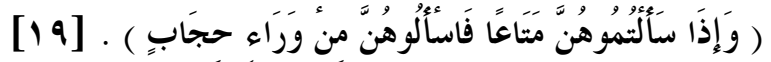

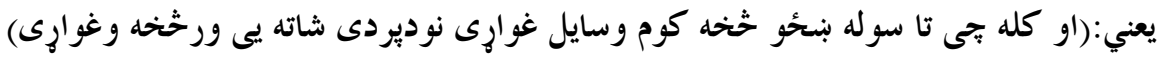

$$
\text { داستدلال طريقه : }
$$

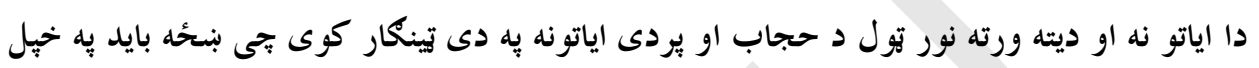

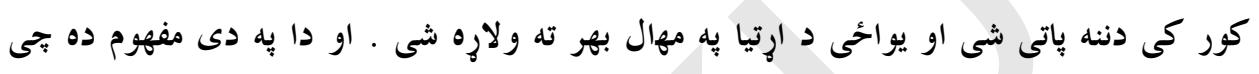

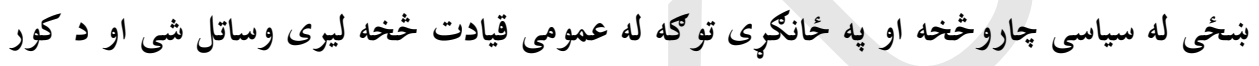

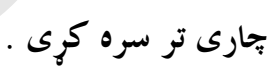

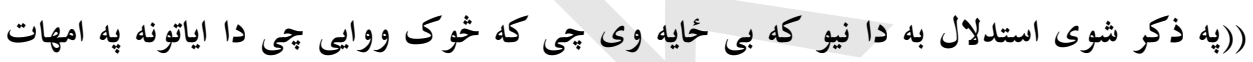

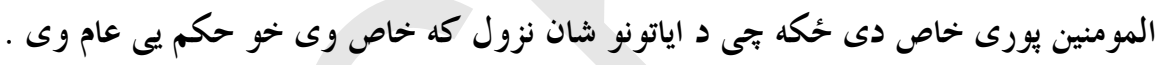

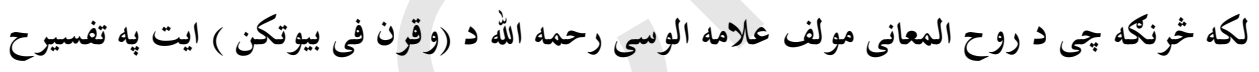

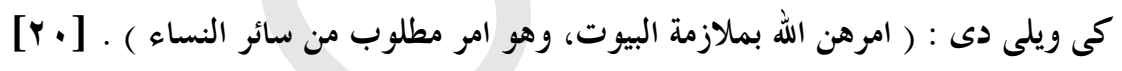

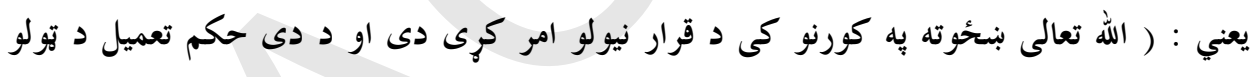

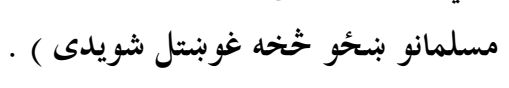

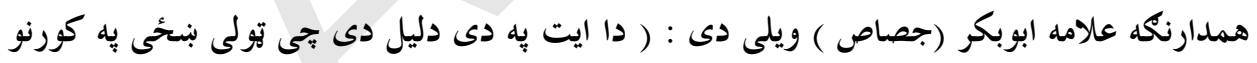

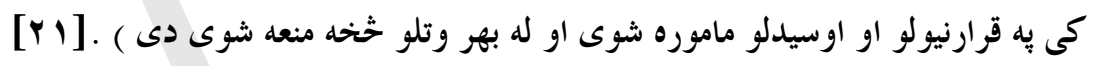

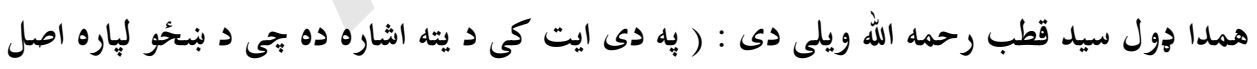

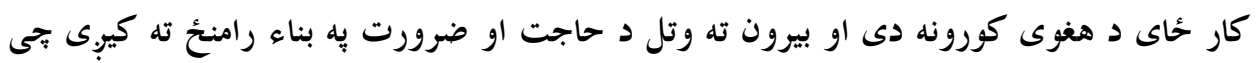

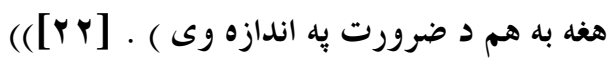

$$
\begin{aligned}
& \text { دوهم : له نبوى حديثونو خخه : }
\end{aligned}
$$

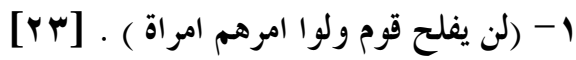

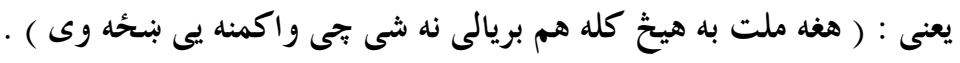




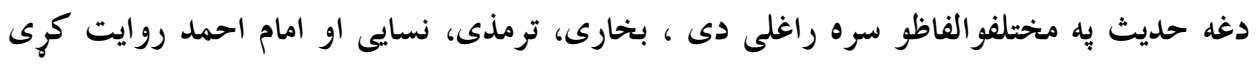
دى ، البته ترمذى دغه حديث غريب بللى دى .

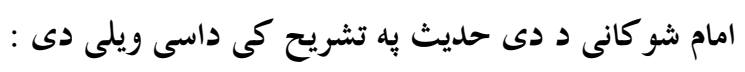

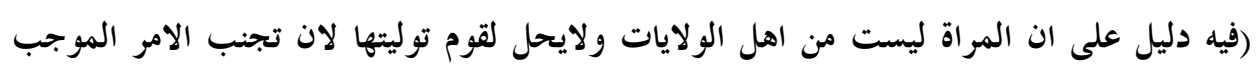

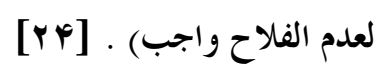

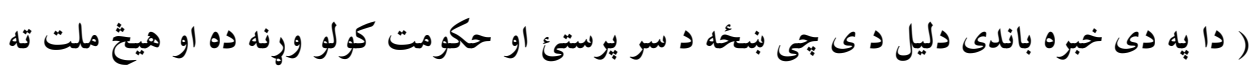

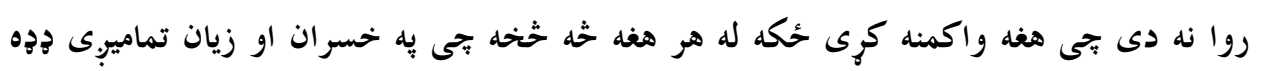

$$
\text { كول ضرورى دى ) . }
$$

همدارنكه علامه ابن عابدين ويلى دى : ( واماتقريرها فى نحو وظيفة الامام فلاشك فى عدم صحته

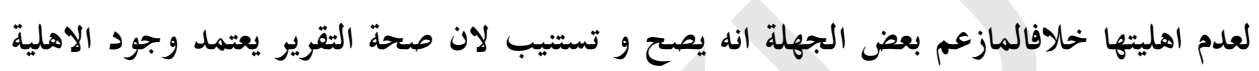

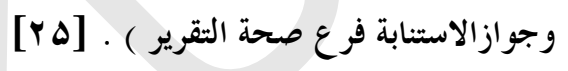

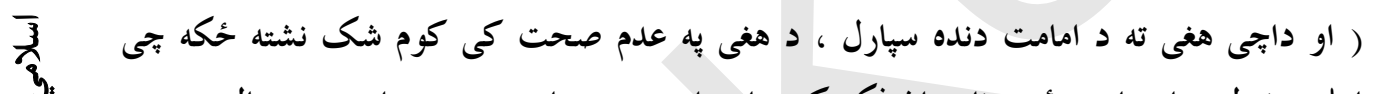

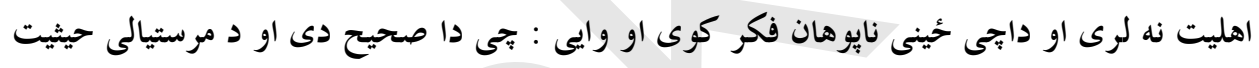

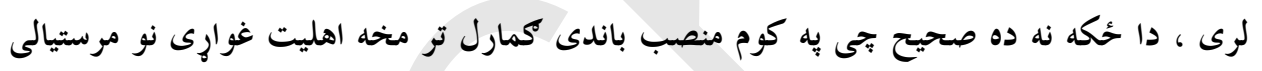

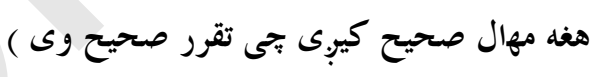
د نومورى حديث خخه د استدلال طريقه :

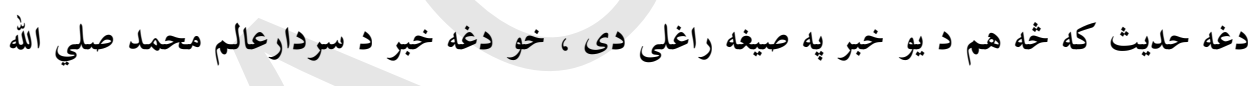

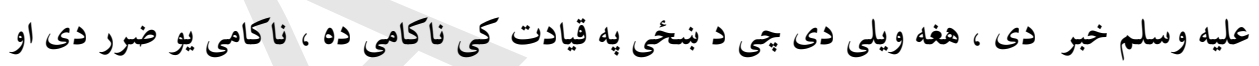

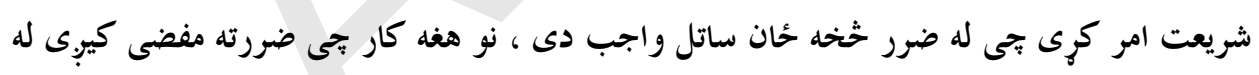

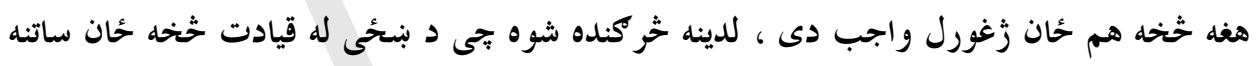

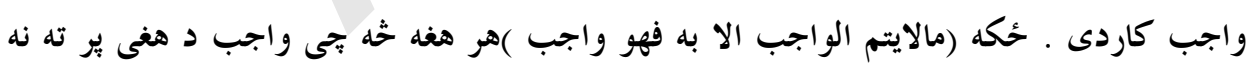

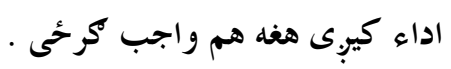

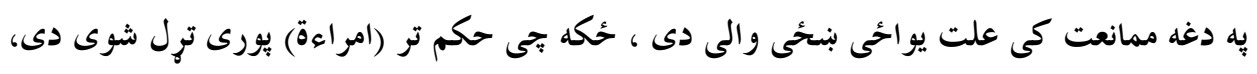

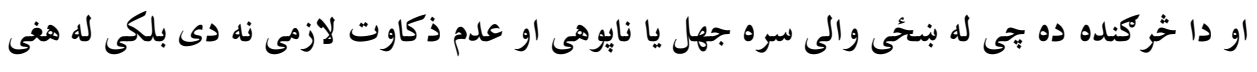

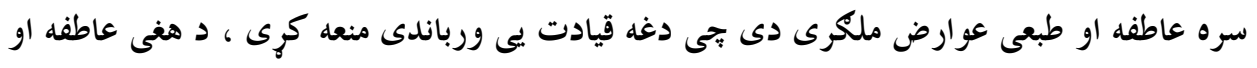

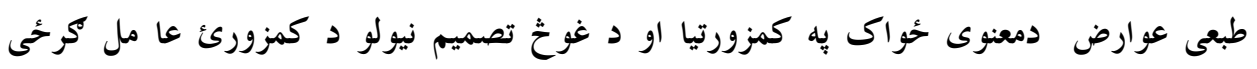




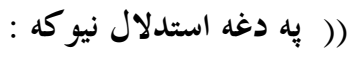

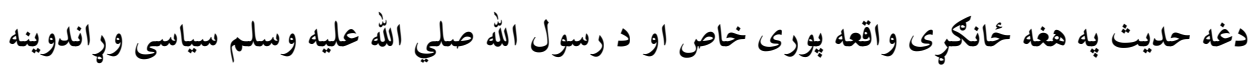

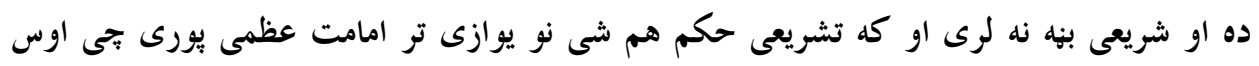

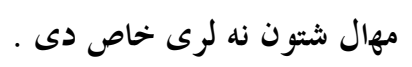

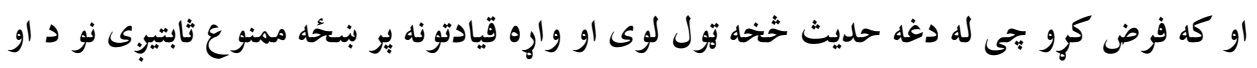

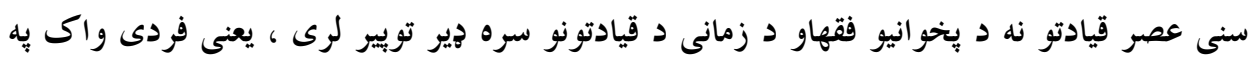

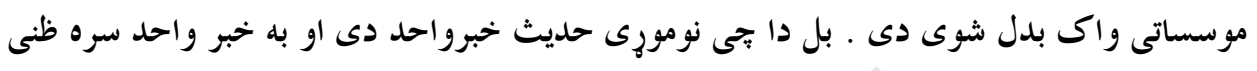

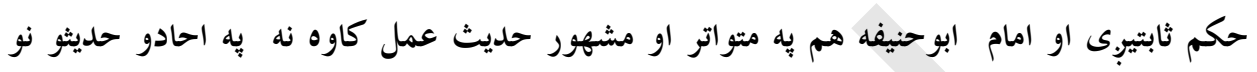

د يادى شوى نيوكى حؤاب:

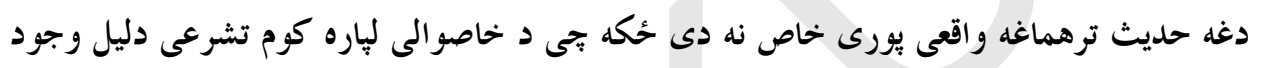

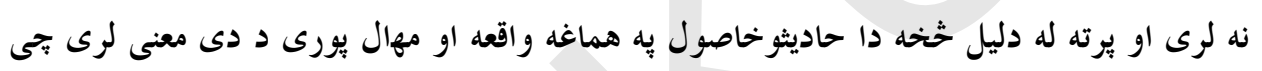

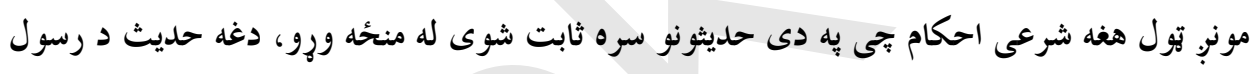

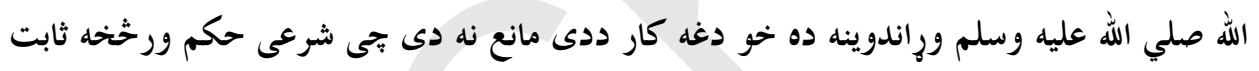

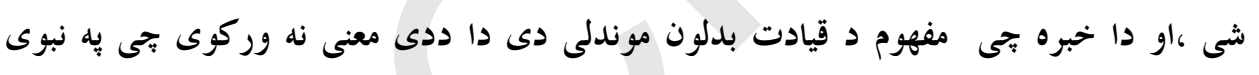

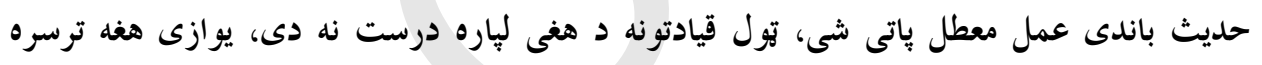

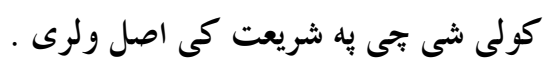

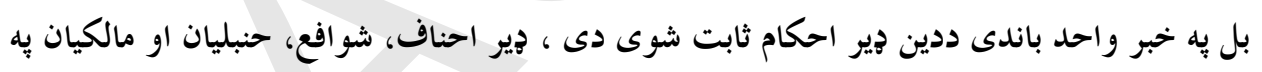

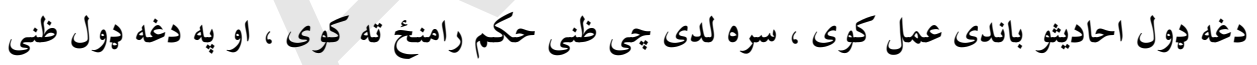

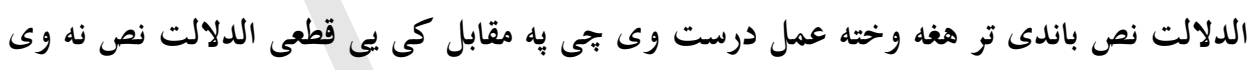

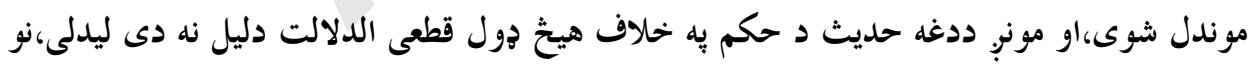

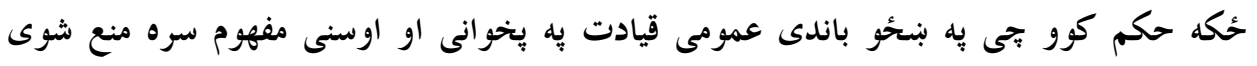
دى. (

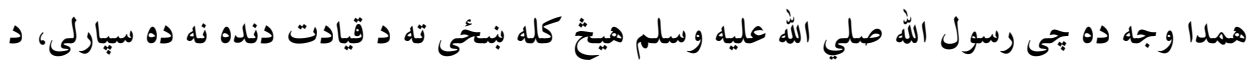

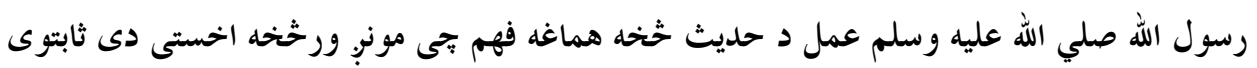

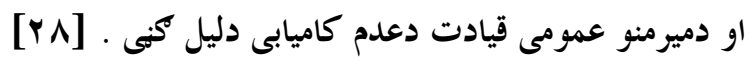


r- ( و اذا كان امراو كم شرار كم و اغنياو كم بخلاء كم و امور كم الى نساءكم فبطن الارض

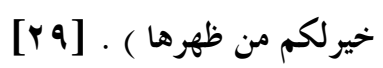

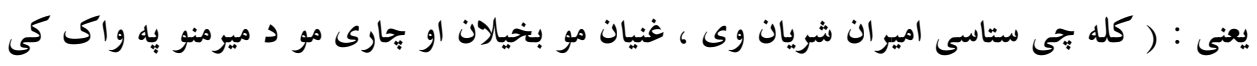

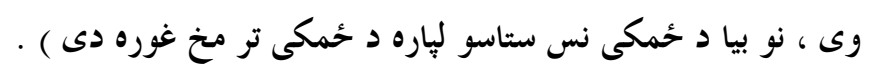

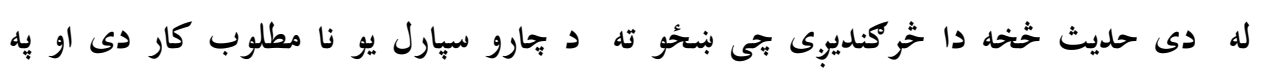

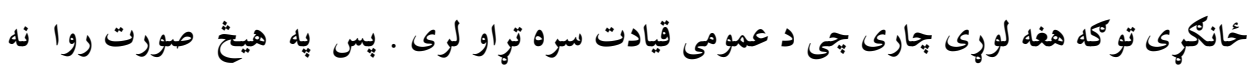

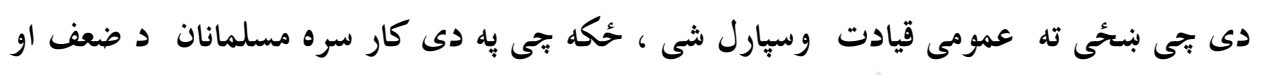

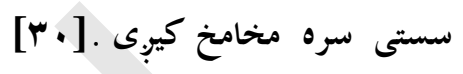

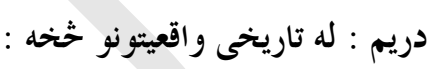

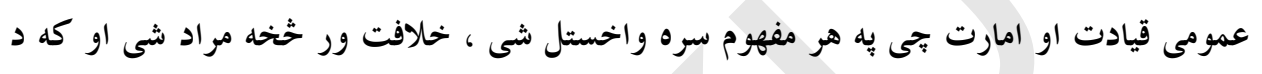

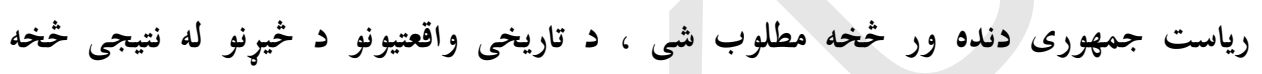

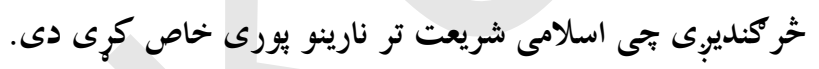

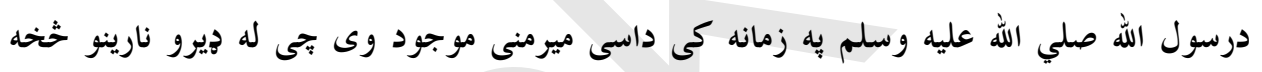

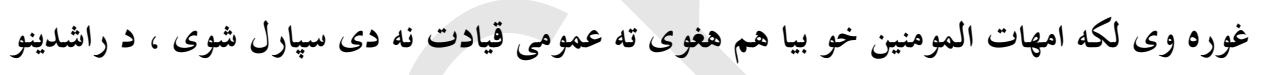

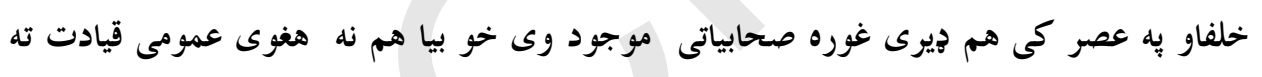

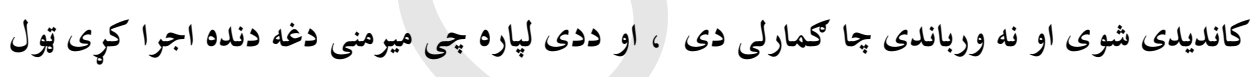

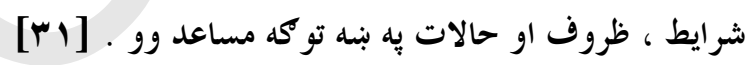

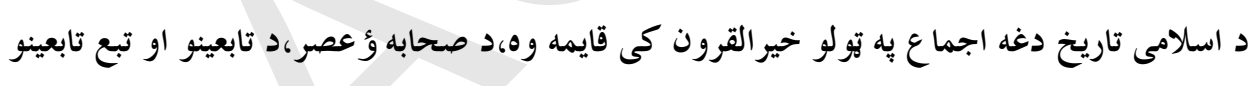

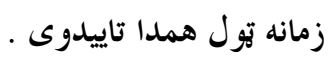

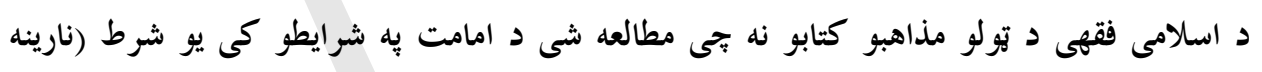

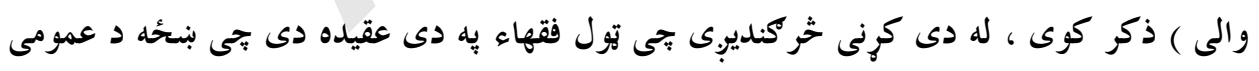

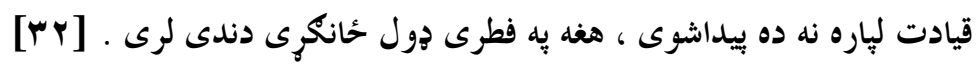
خلورم : قياس او عقلى دلايل :

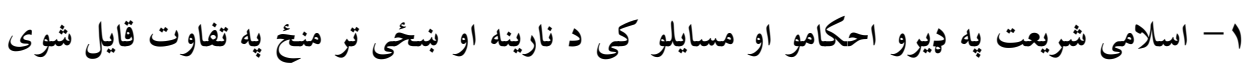

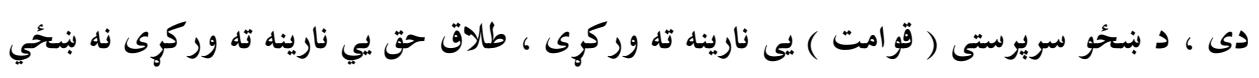

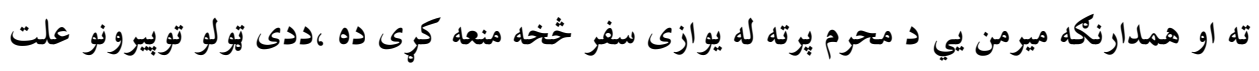




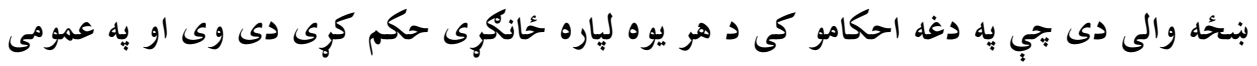

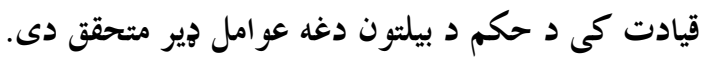

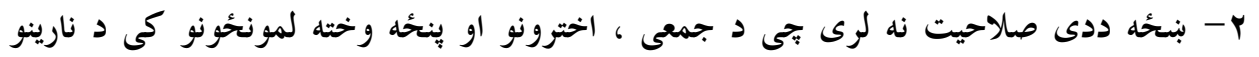

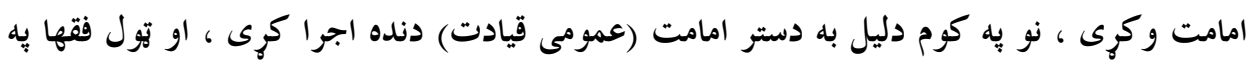

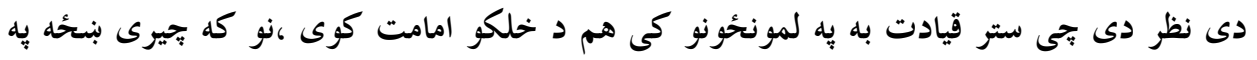

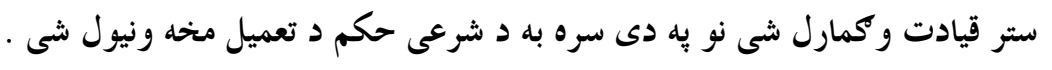

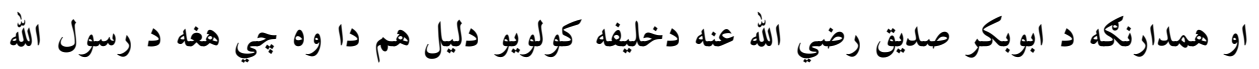

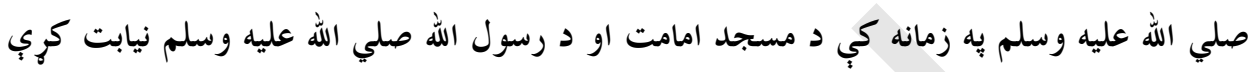

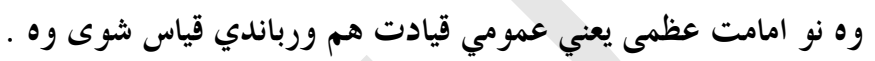

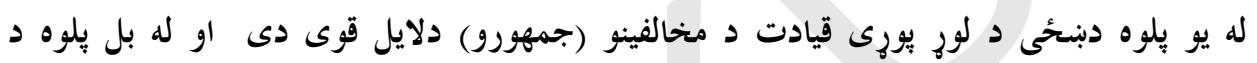

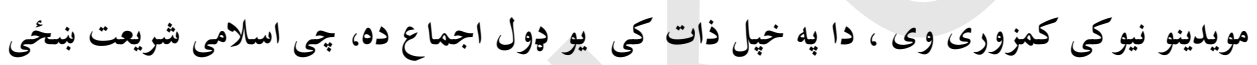

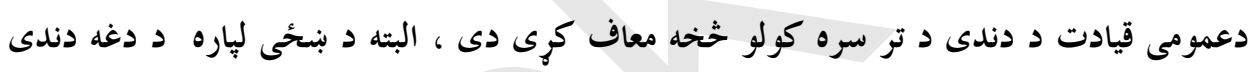

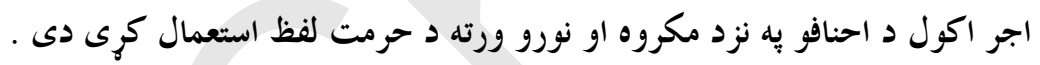

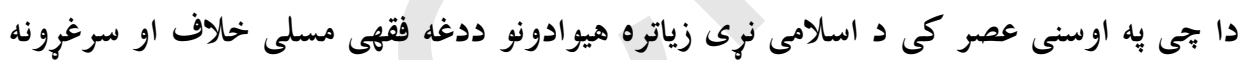

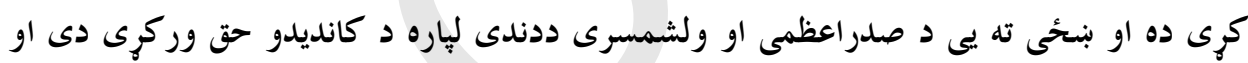

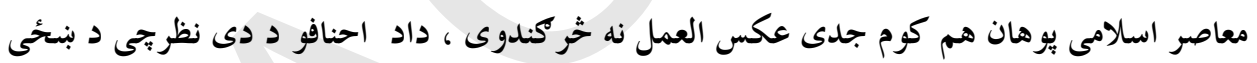

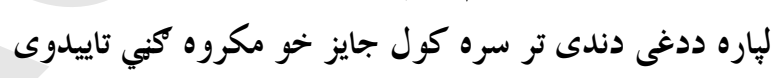

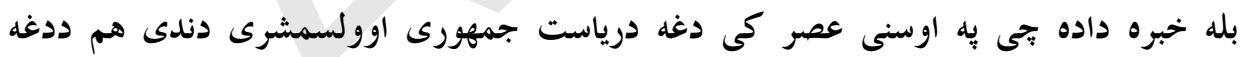

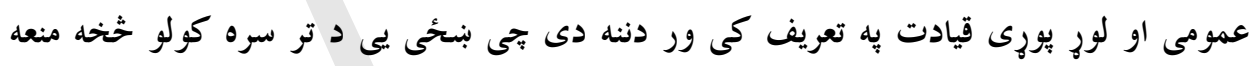

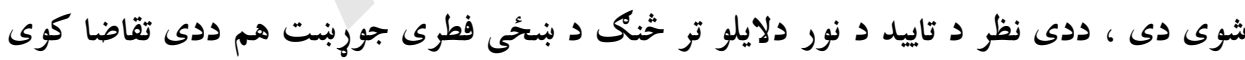

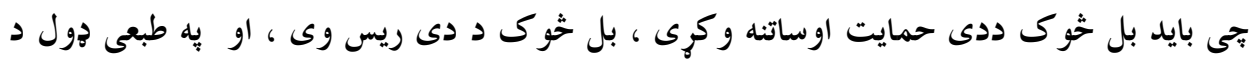

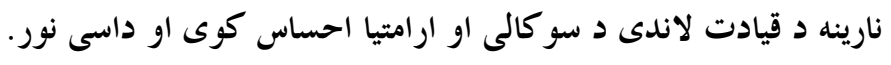

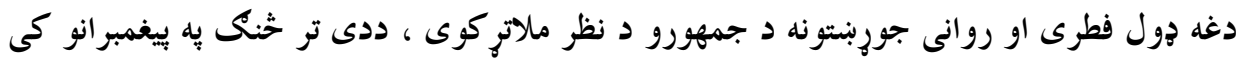

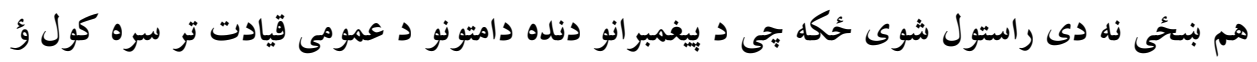

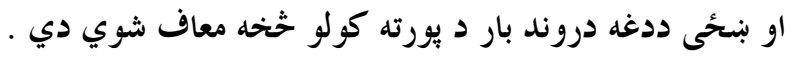




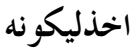

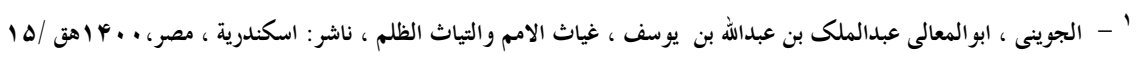

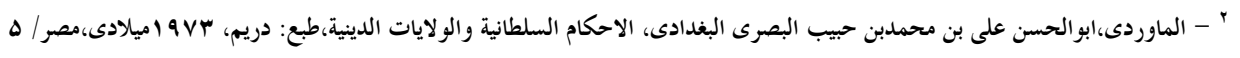

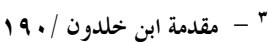

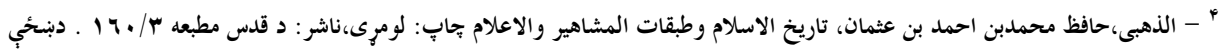

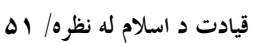

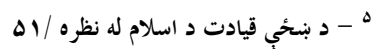

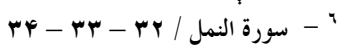

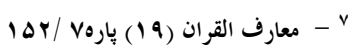

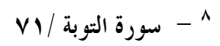

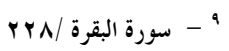

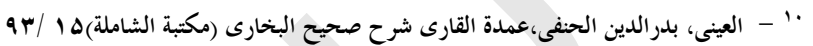

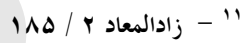

اله

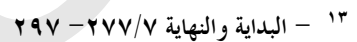

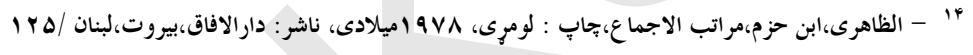

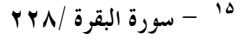

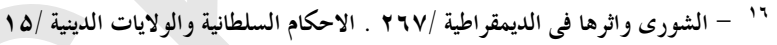

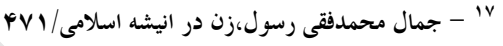

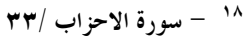

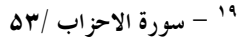

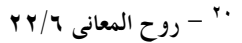

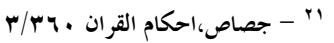

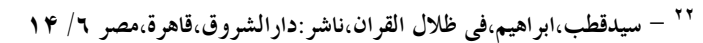

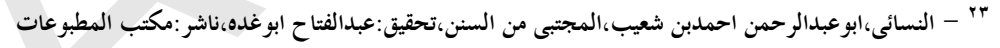

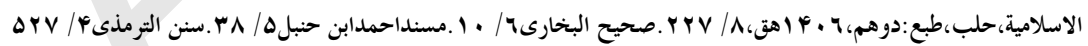

9/1

m

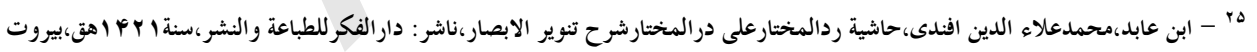

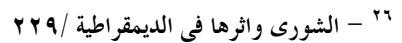

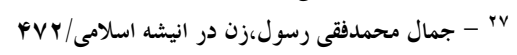

$11 / r \Lambda \cdot 1 / \mu$

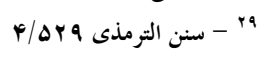

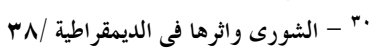

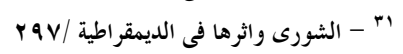

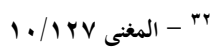




\section{دفاع مشروع در قانون جزا}

Kان قانمل سهيلا الفى نور

\section{جִ:كيده}

آنجه را در /ين صفحات كرد آورده و به عنوان يكى مقاله بيشكش مينمايم بحث /ز عرض يك حق كه در نتيجه و بيامد يكى عمل جرمى كه خواه در اثر تعرض و تجاوز واقع شده باشد يا همر در

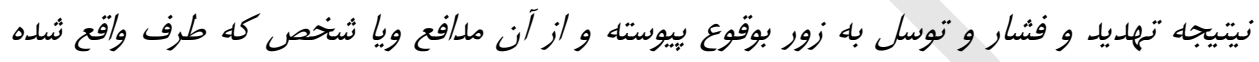

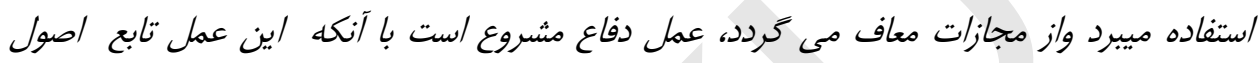

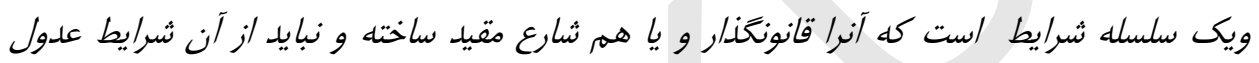
صورت كرفته و از /ين حق /ستفاده سوء كردد ـ دفاع /ز جان، مال و ناموس افراد به عهله دولت است، افراد حق دفاع مستقيه /ز خود را نداشته و نمى توانند به مقابله برداخته و انتقام خود را از متجاوز

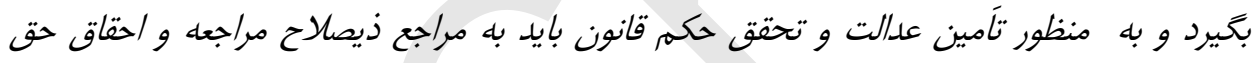

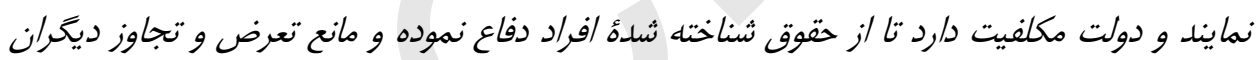

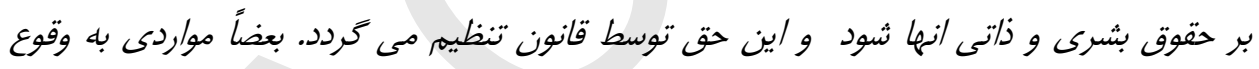
مييوندد كه دفع تجاوز /ز طرف دولت ممكن و ميسر نبوده، درينصورت قانون به افراد حق ميدهد تا تاني

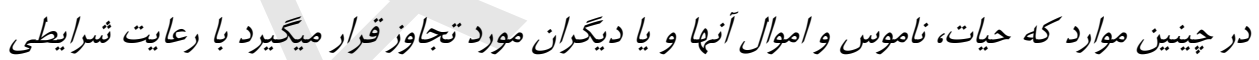
كه در قانون در رابطه به حمله و تعرض و رعايت تناسب ميان آنها وضع شده است، اقدام نمايند و

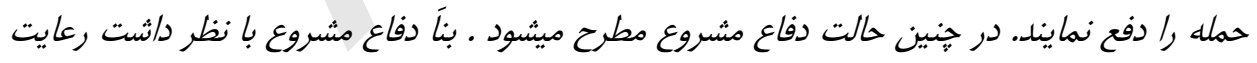

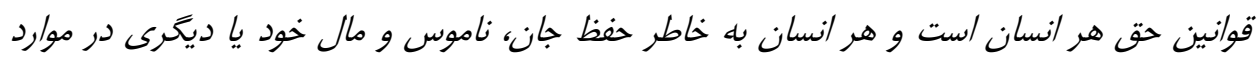
ضرورى از آن استفاده مى نمايد.

\section{وازه هاي كليدى}

دفاع مشروع، مدافع، تعرض، خطرتجاوز، نفس، مال و ناموس و معافيت مرتكب از تعقيب و 
مقدمه

ازآ نجا كه انسان در داخل اجتماع زيست نموده در برابر تعهد و ميثاقى كه ميان وى و دولت وجود دارد، دفاع از جان، ناموس و مال افراد به عهده دولت است. افراد حق دفاع مستقيم از خويشتن را ندارند و نه مى توانند به مقابله بَالمثل دست زده، انتقام خود را راز متجاوز بكيرند. آنها به خاطر تأمين عدالت و تحقق حكم قانون بايد به مراجع ذيصلاح

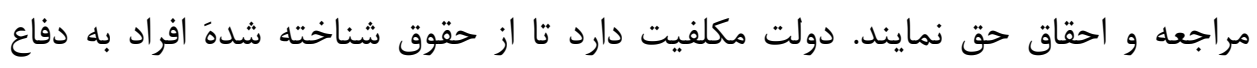
يرداخته، مانع تعرض وتجاوز ديكران بر حقوق انها شود اما موارد عرض اندام مينمايد كه دفع

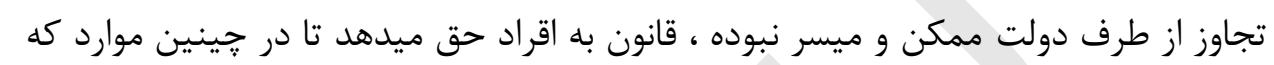

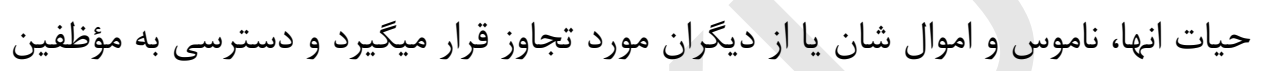
خدامات عامه جهت دفع تعرض وجود نمى داشته باشد. با رعايت شرايطى كه در قانون

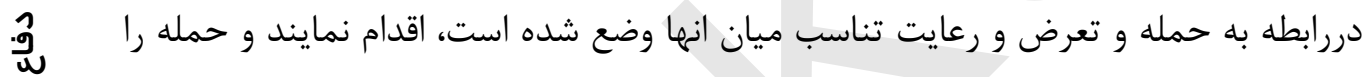

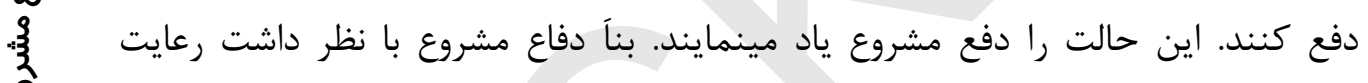
قوانين حق هر انسان است و هر انسان به خاطر حفظ جان، ناموس و مال خود ياديخرى در

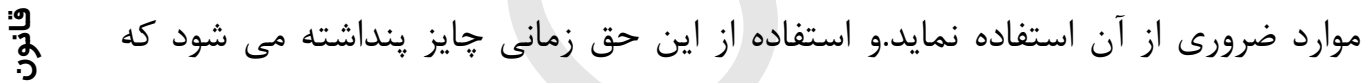

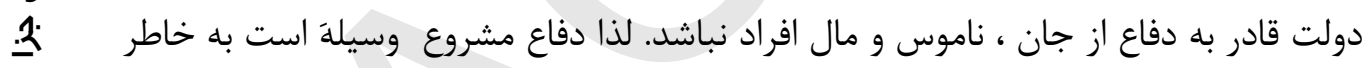
جلوكيرى از خطر تجاوز كه دفع ان جز از طريق ارتكا ب جرم ممكن نباشد ، ولى نبايد اين

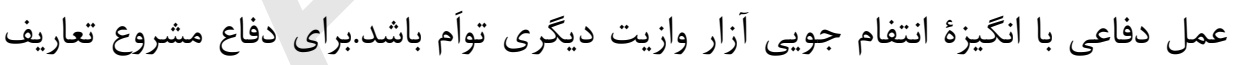
متعددى ارائه شده است جنانجه: دفاع مشروع عبارت از دفع حمله نا حق نسبت به جسم، جان مال، ناموس، عرض و آزادى تن خود يا ديخرى در خارجوب قانون.( ) اردبيلى،محمدعلى. حقوق جزاى عمومى .

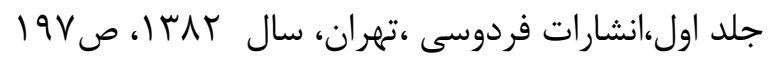


و يا در تعريف ديكر، دفاع مشروع يا دفاع قانونى عبارت است از توانايى بر دفع تجاوز

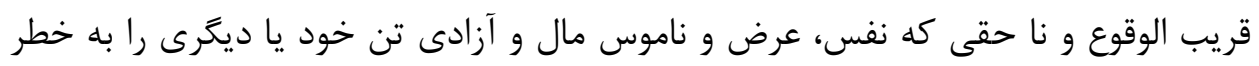
انداخته است. (广)

و همجنان در تعريف ديگر دفاع مشروع جنين تعريف شده است. دفاع مشروع حقى است كه قانون براى شخصى كه مورد حمله ظالمانه قرار گرفته، مقرر كرده است تا در هنگام ضرورت و عدم دسترسى به قواى دولتى، آن شخص بتواند با استفاده از وسايل متناسب، براى دفع خطرى كه جان، مال و ناموس خود و يا ديكرى را تهديد كرده است، با اعمال زور و ايراد صدمه به متجاوز اقدام كند. مطابق قانون جزا ارتكاب عمل جرمى به منظور استعمال حق، دفاع مشروع جرم ينداشته نمى شود حق دفاع مشروع زمانى به وجود مى آيد كه دفاع كننده روى اسباب معقول و دلايل منطقى يقين نمايد كه خطر تجاوزبرمال، جان يا ناموس دفاع كننده و يا شخص ديگرى متوجه است. اين حق تا زمان ادامه خطرادامه مى يابد. طبق احكام قانون جزا حق دفاع مشروع به شخص مورد تهديد اجازه مى دهد تا از استعمال وسايل لازم به منظور دفاع از هر عمل جرمى ايكه ضرر يا خطر جانى و مالى براى دفاع كننده و يا شخص ديكرى توليد نمايد استفاده كند.

$$
\text { تعريف دفاع مشروع }
$$

دفاع مشروع عبارت از حق استعمال وسايل متناسب به منظور دفاع از هر عمل جرمى كه ضرر و خطر جانى يا مالى را به دفاع كننده و يا شخص ديگرى توليد نمايد . ( (Y) ص ( I I )

در تعريف ديكر آمده است كه دفاع مشروع عبارت از دفع حملهُ ناحق نسبت به جسم،

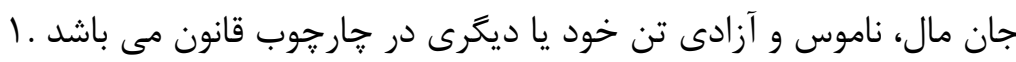


و يا در تعريف ديكر، دفاع مشروع يا دفاع قانونى عبارت است از توانايى بر دفع تجاوز قريب الوقوع و نا حقى است كه نفس و ناموس، مال و آزادى خود يا ديخرى را به خطر

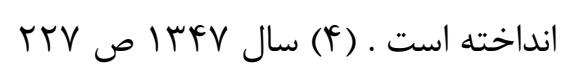

و همجنان در تعريف ديگر دفاع مشروع جنين تعريف شده است: دفاع مشروع حقى

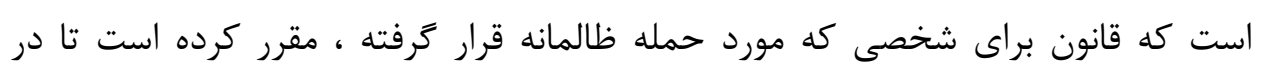
هنگام ضرورت و عدم دسترسى به قواى دولتى، آن شخص بتواند با استفاده از وسايل

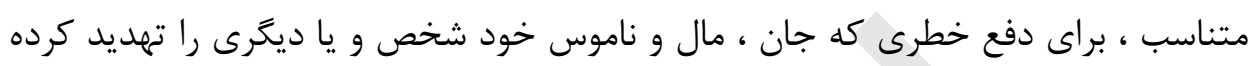

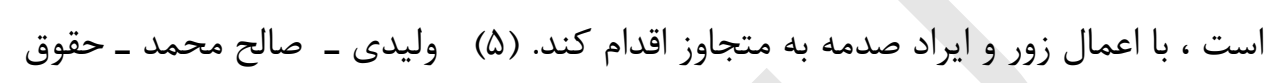

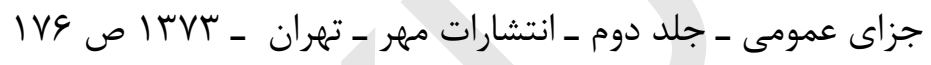

\section{ييشينه تاريخى دفاع مشروع}

دفاع امريست كه ريشه آن از بدو ييدايش آدمى موجود بوده و اين امر نه تنها منحصربه

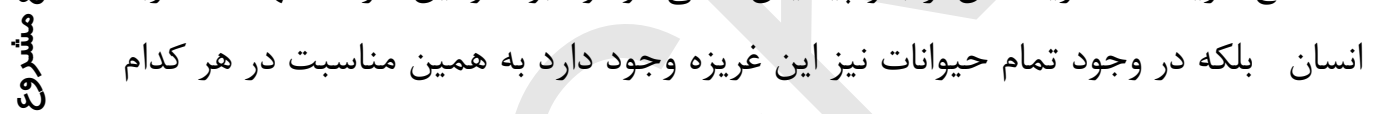

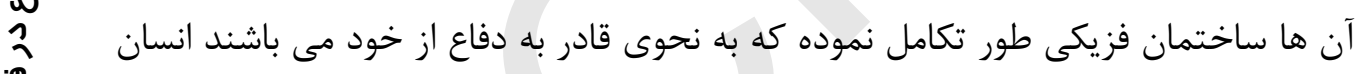
منحيث موجود متكامل هستى و اشرف مخلوقات با داشتن قدرت تفكر و تدبر هنكام مواجه .1. شدن به خطر حق دارد، راه بهتر را اختيار كند.

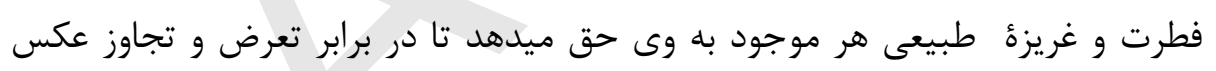

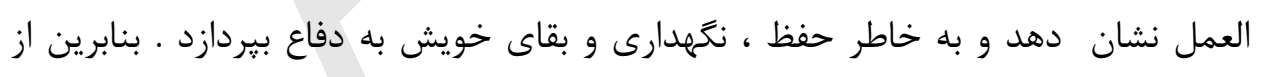
زمان هاى قديم بدين سوء اين امر منحيث يك اصل و قاعده عام مورد قبول واقع شده است

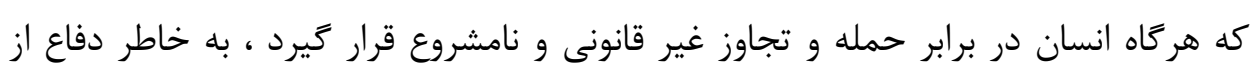

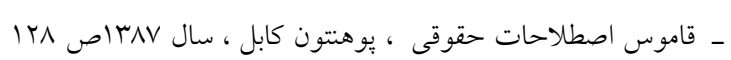

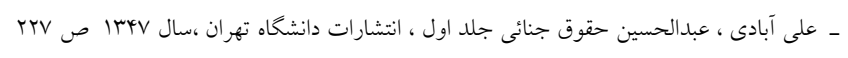

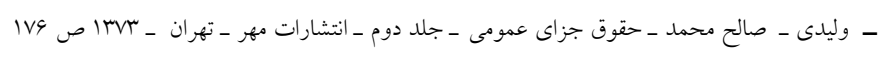

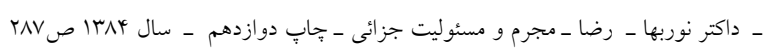


جان ، مال و ناموس حق دارد از خود دفاع نمايد و اگر جنين حالت مرتكب جرم گردد قابل

$$
\text { مجازات دانسته نمى شود. }
$$

در حقوق روم دفاع مشروع جرم شناخته نمى شد در فرانسه تحت تاثير انديشه هاى

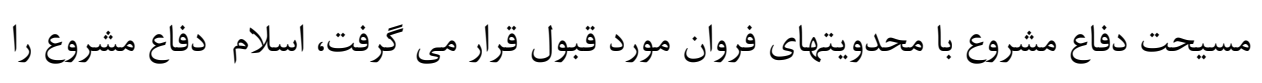
تحت شرايط خاص قابل قبول دانسته است. ( 9)داكتر نوربها ـ ـ رضا ـ مجرم و مسئوليت

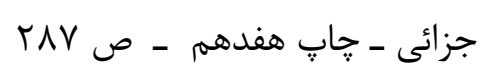

\section{شرايط دفاع}

مدافع به خاطر حمايت حق خود يا ديخرى بايد در برابر متعرض و متجاوز مرتكب عمل

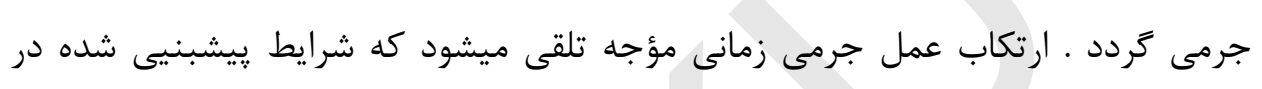

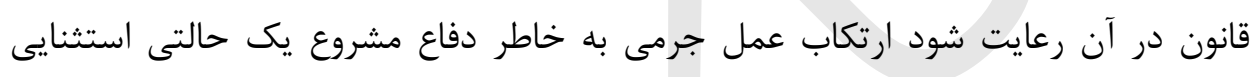

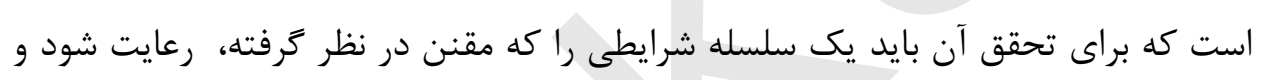

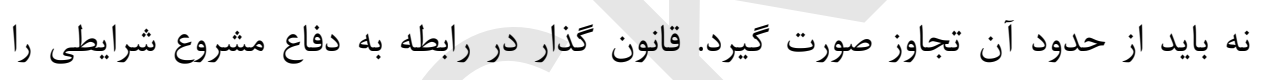

$$
\text { تسجيل نموده كه عبارت اند از: }
$$

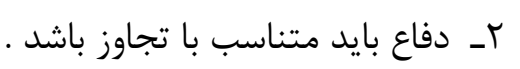

ا ـ ضرورى بودن دفاع : مقصد از ضرورى بودن دفاع آن است كه بخاطر دفع حمله و

تجاوز و دفع خطر از متعرض عليه ، هيج راه و خاره ديكرى جز ارتكاب جرم وجود نداشته

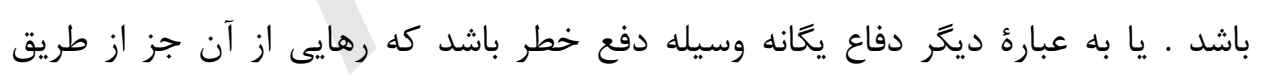

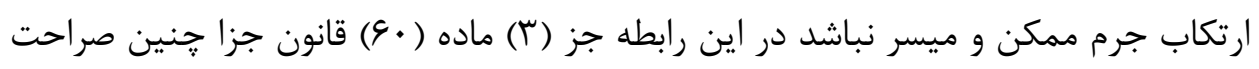




$$
\text { "دفاع تنها وسيله دفع خطر باشد". ( V) قانون جزاى افغانستان }
$$

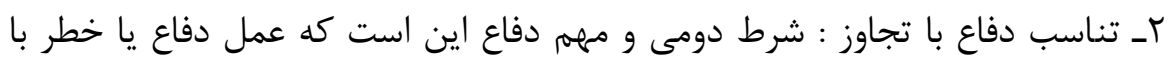

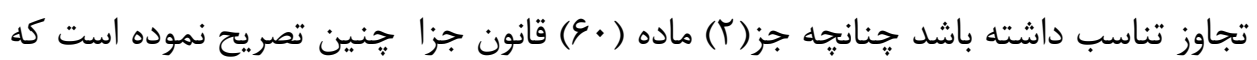

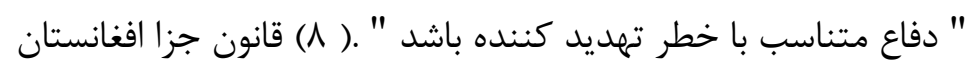
با نظر داشت شرايط كه در قانون جزا درج كرديده شخص دفاع كننده نمى تواند به

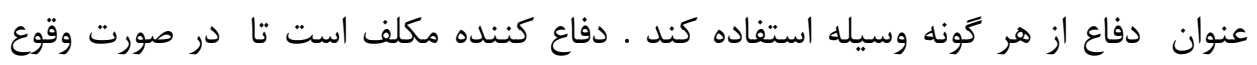
همجو حادثه يك حالت تناسب رادر نظر بخيرد .

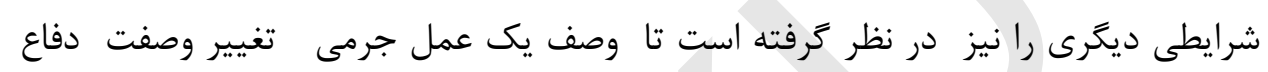
مشروع را بخود كسب نمايد :

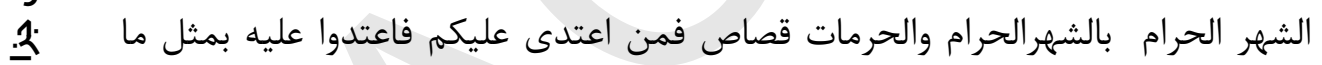

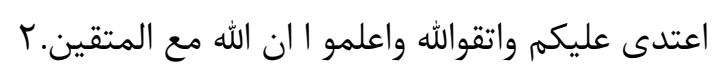

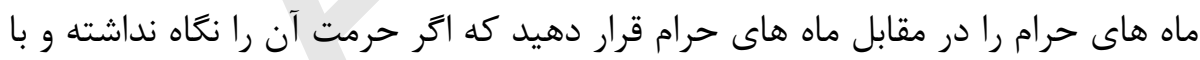
شما قتال كنند شما نيز قصاص كنيد يس هر كس به شما تجاوز كرد بمانند او بر او تجاوز

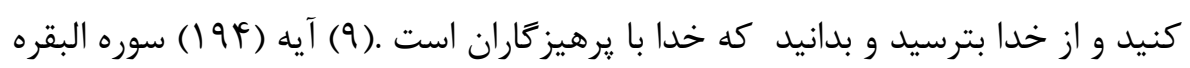


بناً با در نظر داشت تعاريف كه ازدفاع مشروع صورت گرفته، دفاع مشروع زمانى تحقق مى ويذيرد كه تعرض و حمله وجود داشته باشد و آن نيز تحت يك سلسله شرايط عملى شده

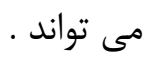

\section{مشروعيت دفاع مشروع}

براى اينكه دفاع مشروع مطرح گردد و آنجه در اثر ارتكاب يك عمل جرمى بوقوع مى ״يوندد عبارت از تعرض و تجاوز است كه در حق غير صورت گرفته و براى دفع جنين تعرض

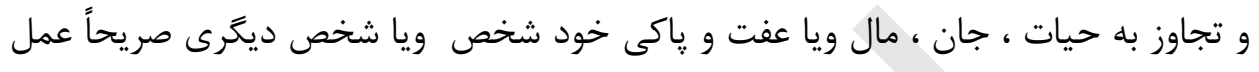

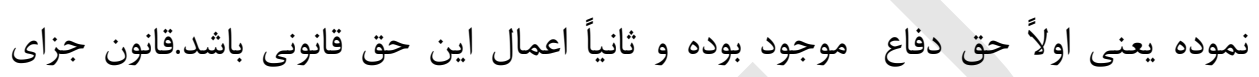

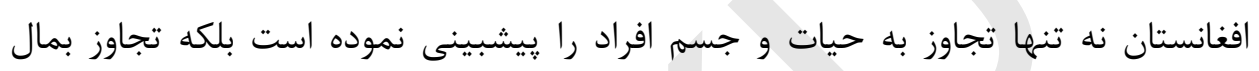

وعفت و ياكدامنى را نيز يِشبينى نموده است.(• (1) قانون جزاى افغانستان

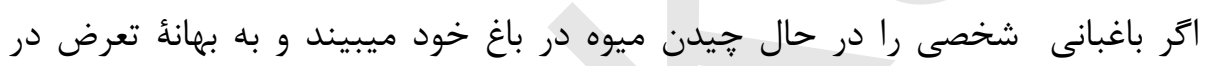

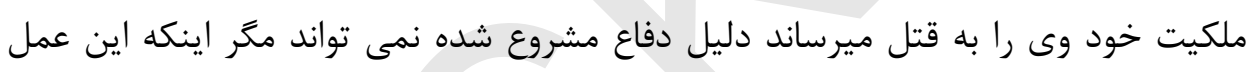

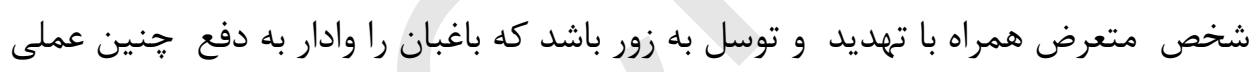
نموده است . مان. قانون جزاى افغانستان علاوه بر عمل (تجاوز) در ماده (هᄉ) از ( تهديد) نيز ذكر نموده است. حق دفاع مشروع به شخص مورد تهديد اجازه ميدهد تا از استعمال وسايل لازم به إنه

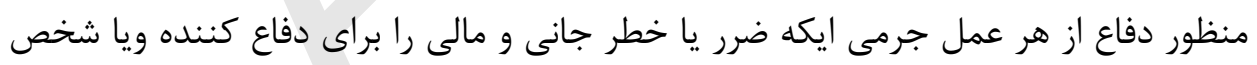

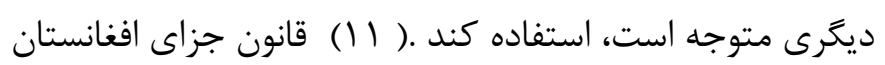

براى مشروعيت يك عمل جرمى به حيث دفاع مشروع بايد دو اصل كه بيشتر مطرح است در نظر كرفته شود: - n ا ـ حق دفاع موجود باشد يعنى مدافع براى حمايت خود يا حمايت ديخرى نا خار به توسلبهزور شده باشد. rـ اعمال اين حق قانونى باشد يعنى عكس العمل دفاعى از حدود ضرورت تجاوز نكند. 
قانون جزاى افغانستان به دو مورد ديكر كه عبارت از اساب معقول ودلايل منطقى

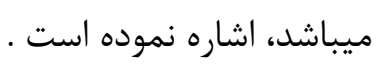

"حق دفاع دفاع مشروع هنكامى بوجود ميايد كه دفاع كننده روى اسباب معقول و دلايل

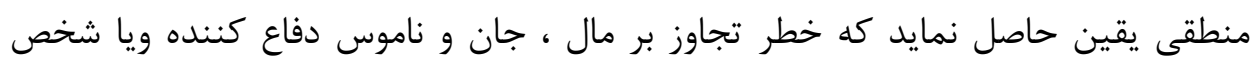

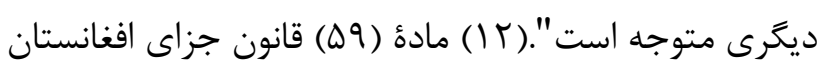

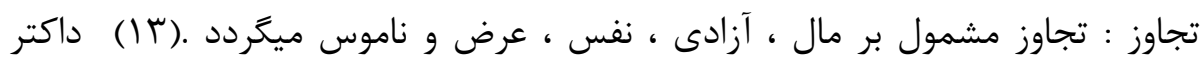

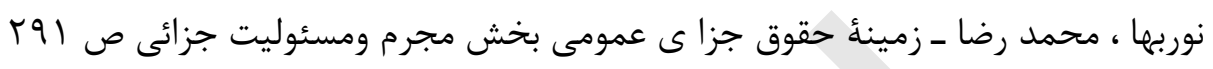
تجاوز به عرض : عرض از نظر لغت شناسى با نفس و ناموس مترادف است ولى براس بيشتر

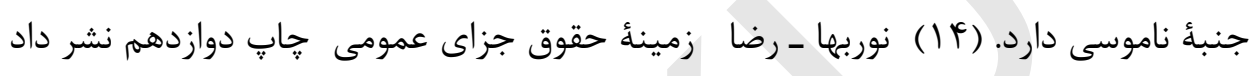

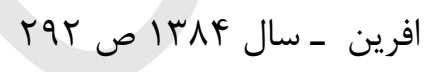

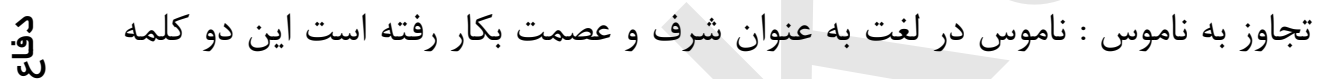

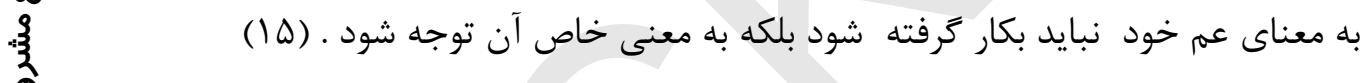

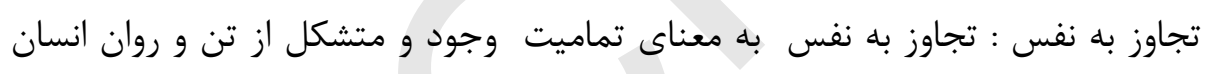

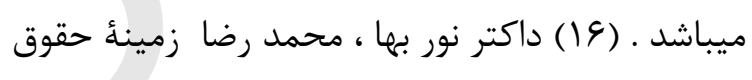

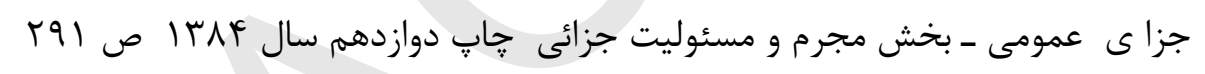

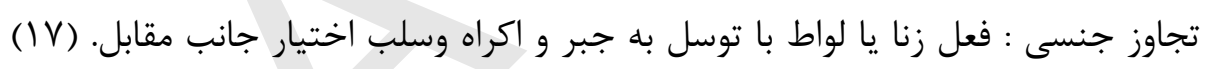

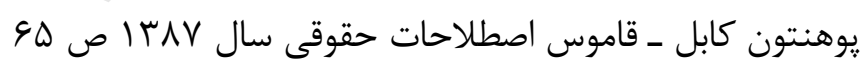

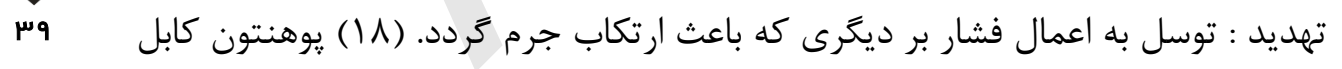

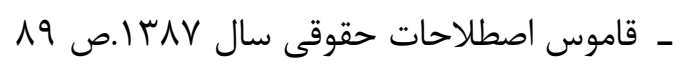

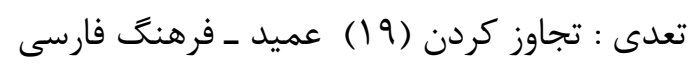

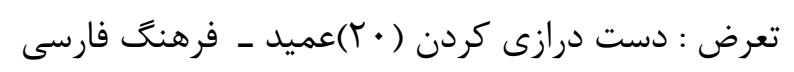




\section{شرايط تعرض يا تجاوز}

دفاع مشروع يك حالت استثنايى به خاطر توجيه عمل جرمى است ، بنابران قانون كذار استفاده از آن را تحت شرايط و حالات خاص، مجاز قرار داده، ولى قلمرو آن را محدود ساخته است . بنابرآن هر نوع تهديد يا خطر و تجاوز به عنوان دفاع مشروع تلقى شده نمى تواند،مَر خطرو تجاوز كه شرايط آن در قانون مسجل و ييشبينى شده باشد. شرايطى كه با تحقق آن، تعرض بر جان ، مال و ناموس شخص و يا ديخرى حق دفاع مشروع را ايجاد مى نى

$$
\text { كند قرار ذيل است : }
$$

اـ تجاوز يا خطر فعاليت وجود داشته باشد يعنى اينكه خطر تجاوز مسلم و قريب الوقوع باشد ، نه اينكه تعرض انجام يافته و يا اينكه در شرف و قوع در آينده باشد . rا- يا تعرض غير مشروع و خلاف قانون باشد، مقصد از غير مشروع بودن تعرض اينست كه تهديد و تعرض به ناحق باشد در صورتيكه عمل تعرض به حكم قانون يا امر آمر باصلاحيت باشد دفاع مشروع در مقابل آن صورت نميخيرد.

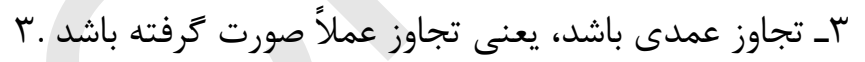

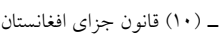

ـ

_

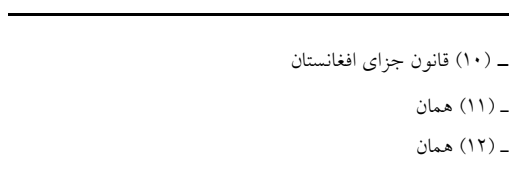


F⿻一 خطر جدى و حقيقى باشد يعنى اينكه دفاع كننده روى اسباب معقول و دلايل منطقى يقين نمايد كه خطر تجاوز موجود است بناً خطر يا تجاوز بايد جدى و حقيقى باشد الشد .

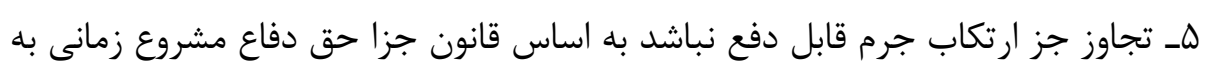
وجود مى آيد كه يكى هم دفاع تنها وسيله دفع خطر باشد.

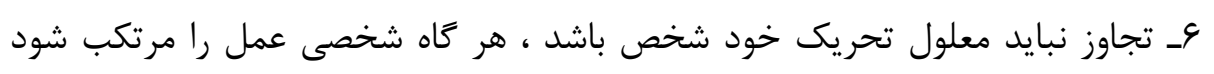

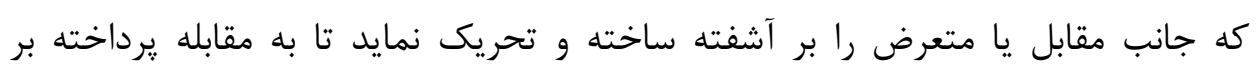

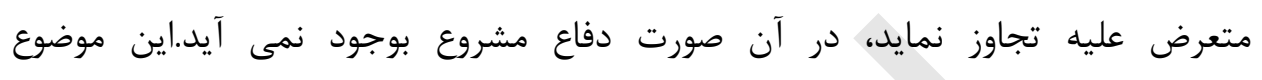

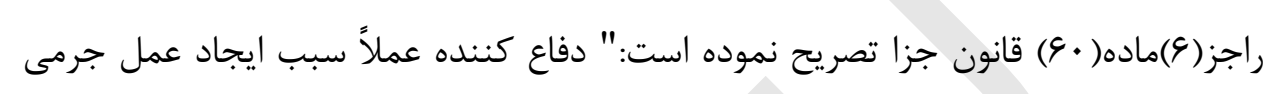
طرف مقابل نشده باشد".(Y) قانون جزاى افغانستان

\section{دفاع مشروع ازنظر دانشمندان}

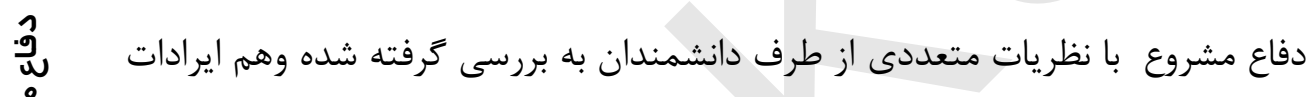

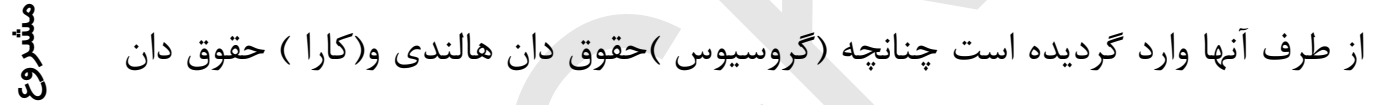

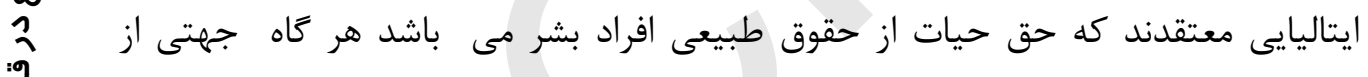

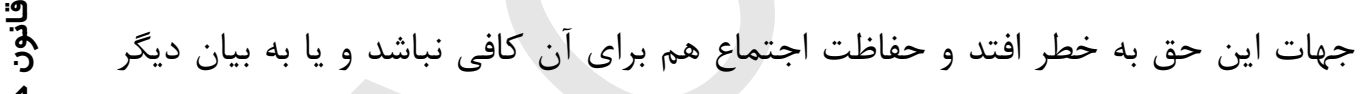

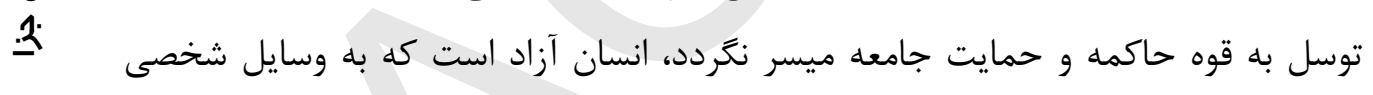
براى حفظ حيات خويش اقدام نمايد. بنابرين هر كاه اين حق از حقوق طبيعى باشد، دفاع 
هم حقيست طبيعى، ولى جنانجه حق كه از آن دفاع ميشود از حقوق طبيعى نباشد، دفاع

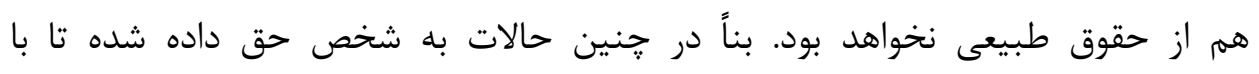

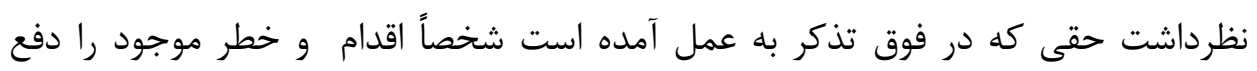
نمايد. اين امر به هيج وجه به معنى انگيزه انتقام جويى و كينه ورزى در برابر ديكران نبوده،

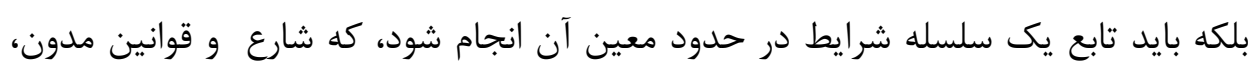

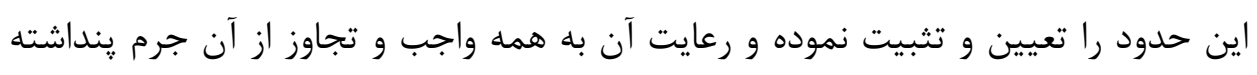

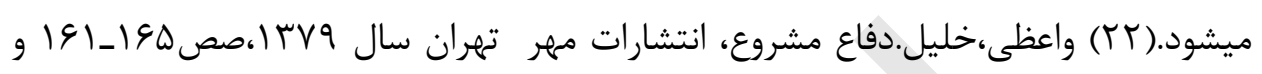

بنابر آن ايرادى كه به اين نظريه وارد شده اين است كه دفاع مشروع صرف در رابطه باحقوق طبيعى مانندحق حيات مطرح بحث شده ميتواند. يعنى صرف زمان كه به نفس يا يان حيات شخص تعرض صورت كيردحق دفاع مشروعيت ييداميكند، ولى در صورت تجاوز به به به عفت، ناموس يا مال شخص حق دفاع را ندارد، زيرا حق ملكيت از جمله حقوق طبيعى نى بلكه يك حق مدنى است.از جانب ديخر هر گاه حيات و ناموس يامال ديخرى مورد تجاوز و

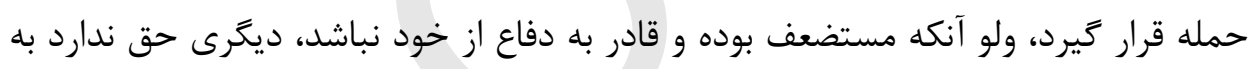
عنوان دفاع مشروع از وى دفاع كند در حالى كه دفاع مشروع در برابر هرنوع تجاوز برجان،

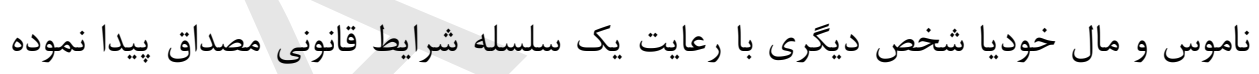

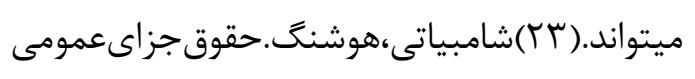

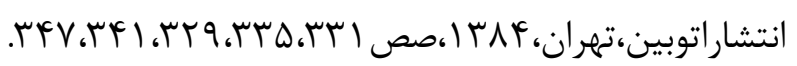

( زان زاك روسو) فليسوف و نويسنده معروف فرانسوى حق دفاع را به نحوى ديخر

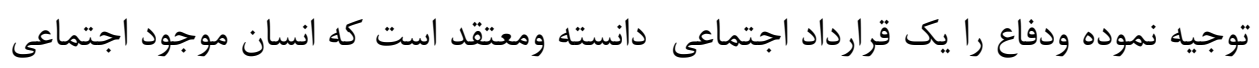
است و مكلف به رعايت حقوق و نظامى است كه براى حفظ و بقاى جامعه لازم است و اين تكليف و وظيفه به مجرد يذ يرفتن عضويت در جامعه خود به خود ايجاد مى شود بنا برين به محض آنكه قرارداد اجتماعى نقض كرديد ، عضوى كه حقوق و منافعش به خطر افتاده مختار نبوده، بلكه مكلف است كه حق و عدالت را به وسايل مقتضى بر قرار سازد. 
- روسـو زان زاكى ـ قرارداد اجتماعى ترجمه عالم حسن زيرك زاده ـ انتشارات مهر تهران - سال به عبارت ديكر طرفداران اين نظريه متعقدند كه انسان به هنگًام تشكيل اجتماع ، حق

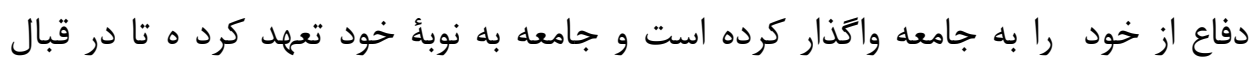
حملات و خطرها از افراد حمايت نمايد . حال اخر كسى مورد حمله قرار كيرد، نشانه آنست كه جامعه به وظيفه خود عمل ننموده و نتوانسته تعهد خود را ايفا كند . به علاوه فرد مهاجم نيز با اين حمله، از قرار داد اجتماعى خارج شده است در جنين حالتى ، طرفين در

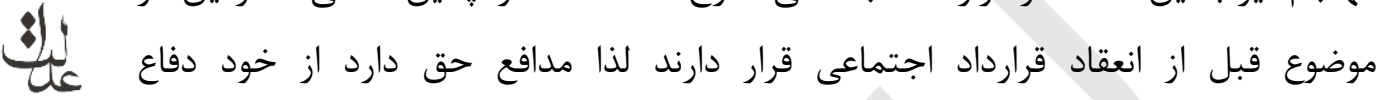

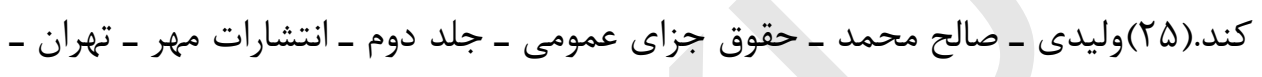

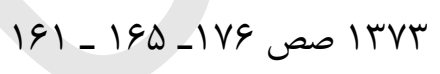

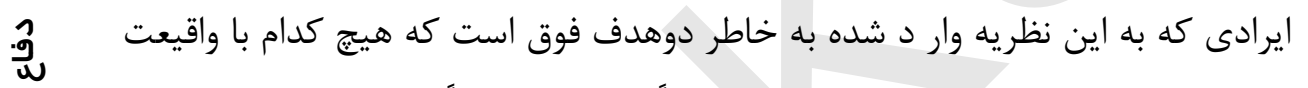

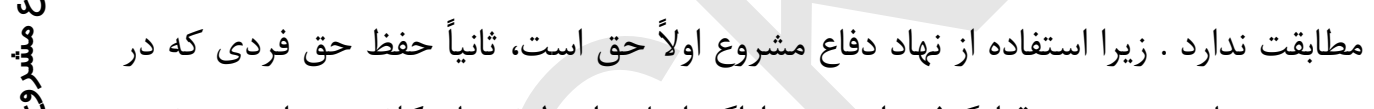

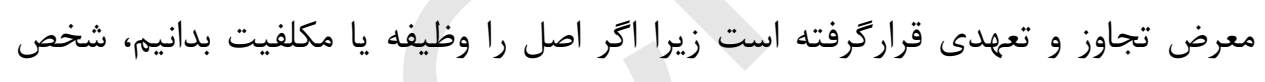

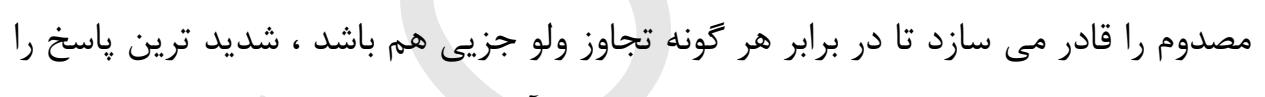

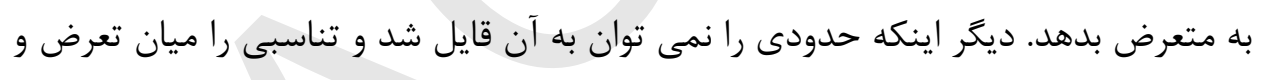

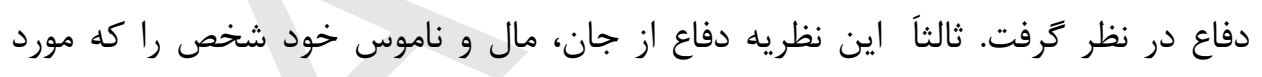

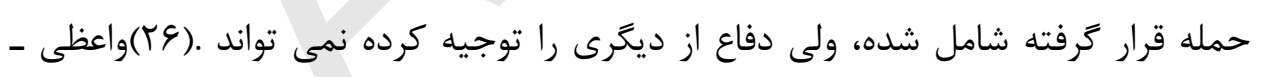

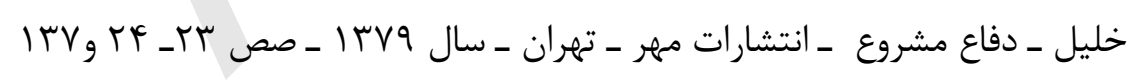
هيگل فيلسوف شهير المانى ميكويد"حمله نفى حق است و دفاع نفى حمله و نتيجتاً دفاع اجراى حق است".(YV) على آبادى ـ عبدالحسين ـ حقوق جنائى ـ جلد اول ـ ـ انتشارات

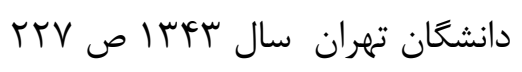
به اساس اين نظر با تعارض دوحق دفاع مشروع بوجود ميايد يعنى هركاه دو حق لق ان متعارض و جود داشته باشد و لازم براى حفظ يكى از آ ن دوحق ،ديخرى فدا شود قاعد تاً

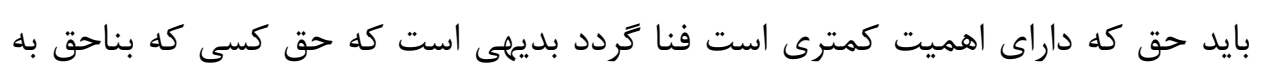


تجاوز قرار زرفته شده، نسبت به حق (شخص متعرض) بايد بيشتر مورد حمايت قرار گيرد

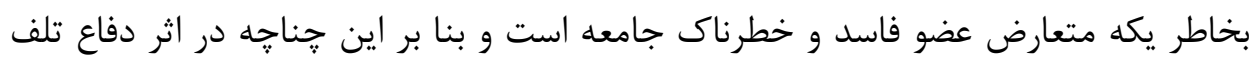

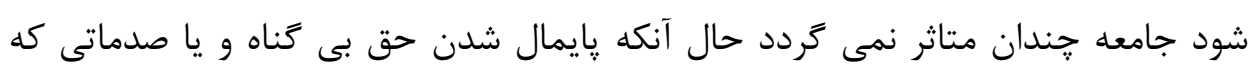

$$
\text { ممكن است در اثر( تعارض) بوجود ميايد. }
$$

ايرادى كه به اين نظريه وارد ميشود اين است كه دو حق در تعارض واقع نميشود. به

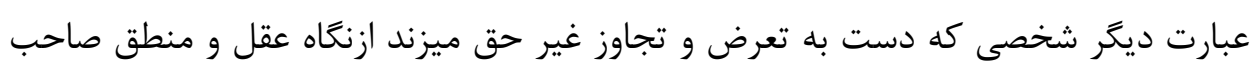

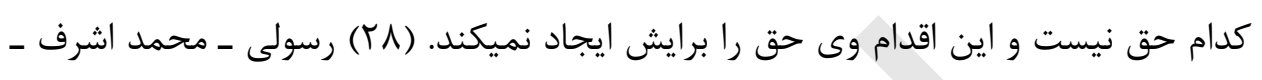

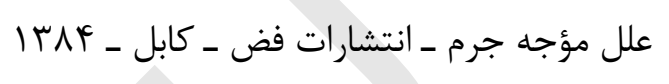

\section{دفاع مشروع از نظر اسلام}

در حقوق اسلام دفاع مشروع به عنوان يك حق شناخته شده است به موجب احكام

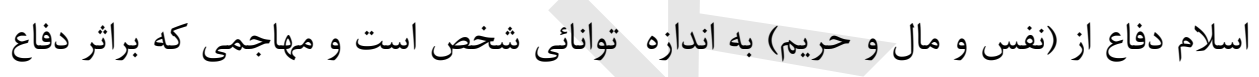
مجروح و يا مقتول كردد، خونش هدر مى باشد. براى مدافع علاوه براينكه مجازاتى مقرر

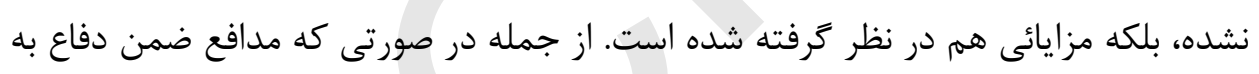

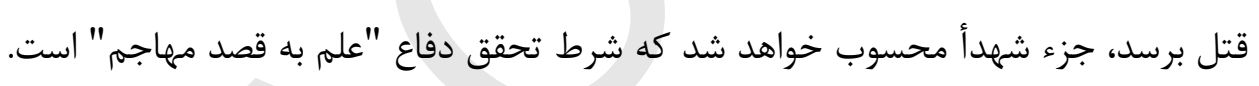

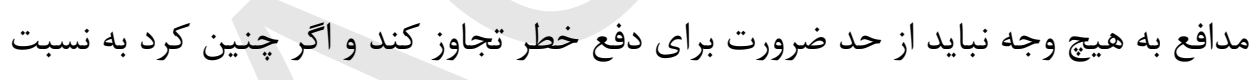
ميزان تجاوز مسئول ارتكابى خود خواهد بود.) وج) واعظى ـ خليل ـ دفاع مشروع ـ انتشارات

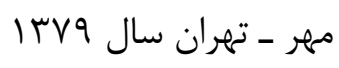
هر كاه كسى شخصى و يا حيوانى را در راه دفاع از خود، از نفس ، غير از مال خود از مال غير و به منظور حفظ از آبرو خود بكشد جيزى بروى نيست زيرا دفع ضرر از نفس و مال و

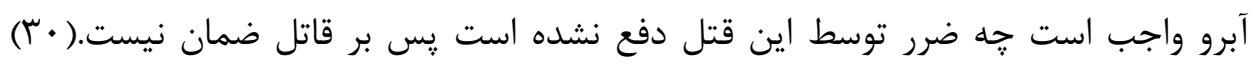

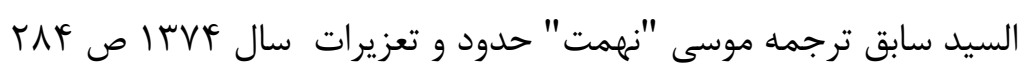
در فقه اسلامى تناسب بين صدمه ناشى از دفاع و صدمه احتمالى حمله، شرط مشروعيت دفاع نيست بلكه وجود ضرورت اقدام دفاعى كافى براى كسب مشروعيت آن مى باشد در 
عين حال رعايت ترتيب در اقدام دفاعى از حيث شدت صدمه وارده كاملا ضرورى ميباشد

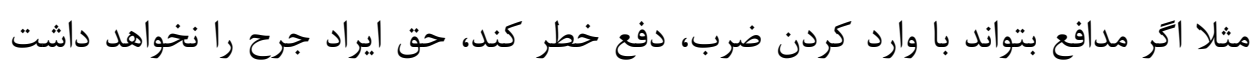
حتى تصريح شده كه اگر مدافع با داد و فرياد و ايجاد سرو صدا موفق شود مهاجم را از تجاوز باز دارد به هيج وجه حق نخواهد داشت كه صدمه اى به او وارد سازد بنا به خاطر تحقق دفاع مشروع موجوديت شرايط آتى ضرور دانسته شده است .

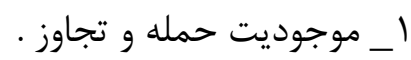

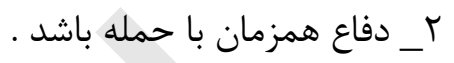

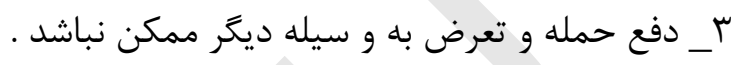

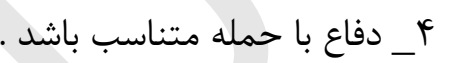
كسى كه بخواهد مالى ديكرى را از دزد بخيرد ، اخر ميسر باشد اورا طرد ، منع و دفع

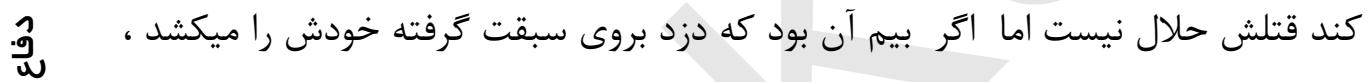

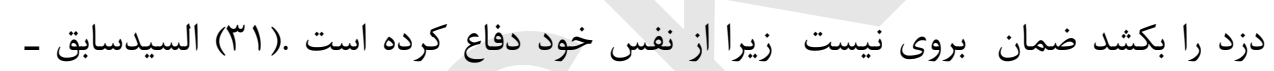

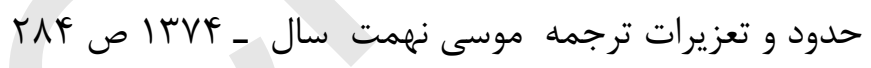

\section{دفاع مشروع در قانون جزا}

مطابق قانون جزا ارتكاب عمل جرمى به منظور استعمال حق دفاع مشروع جرم ينداشته نمى شود حق دفاع مشروع زمانى به وجود مى آيد كه دفاع كننده روى اسباب معقول و دلايل منطقى يقين نمايد كه خطر تجاوز بر مال، جان يا ناموس دفاع كننده و يا شخص

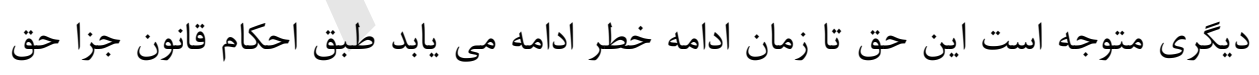
دفاع مشروع به شخص مورد تهديد اجازه مى دهد تا از استعمال وسايل لازم به منظور دفاع از هر عمل جرمى ايكه ضرر يا خطر جانى و مالى براى دفاع كننده و يا شخص ديكرى توليد نمايد، استفاده كند. قانون جزا نهادحقوقى دفاع مشروع را منحيث يك اصل يذيرفته ودرماده(DV)ذكرشده كه

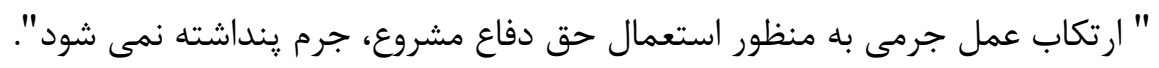


مقنن دفاع مشروع را به حيث يكى از عوامل مؤجه ارتكاب جرم دانسته كه موجب معافيت مرتكب از تطبيق مجازات مى گردد مطابق احكام قانون جزا حق دفاع مشروع به مه ماته شخص مورد تهديد اجازه مى دهد تا از استعمال وسايل الزام به منظور دفاع از هر نوع عمل جرمى ايكه ضرر و يا خطر جانى و مالى براى دفاع كننده و يا شخص ديكر توليد نمايد،

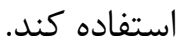

دفاع مشروع در قانون جزا با آنكه دفاع در برابر مؤظفين خدمات عامه اجازه داده نشده ، ولى در احوال استثنايى كه خطر مرى يا جراحات شديد موجود بوده و عمل مؤظفين خدمات عامه تجاوز از حدود و صلاحيت قانونى باشد، اين حق در قانون به مدافع داده شده

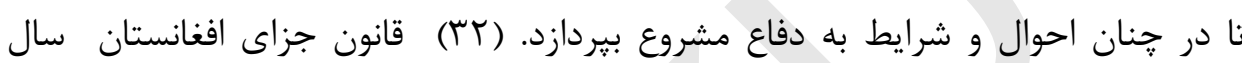

دفاع مشروع به خاطر حفظ جان ، ناموس ومال خود يا ديخرى حق هرانسان شناخته شده است استفاده از اين حق زمانى جايز ينداشته ميشود كه دولت قادر به دفاع از جان ،

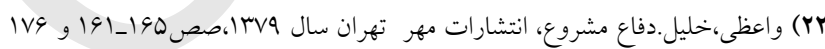
(YY)

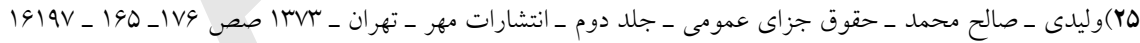

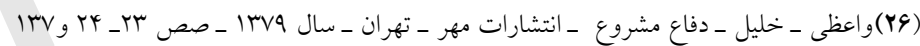

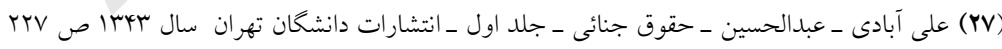

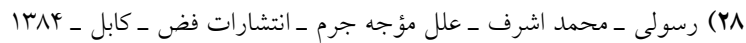

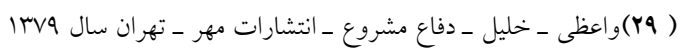

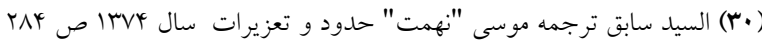

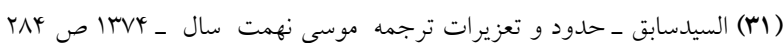

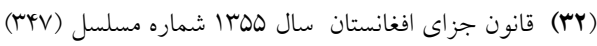

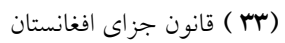


مال و ناموس افراد نباشد ـ لذا دفاع مشروع وسيله اي است به خاطر جلوگيرى از خطر تهديد و تجاوز كه دفع آن جز از طريق ارتكاب جرم ممكن نباشد ، ولى نبايد اين عمل دفاعى با باس

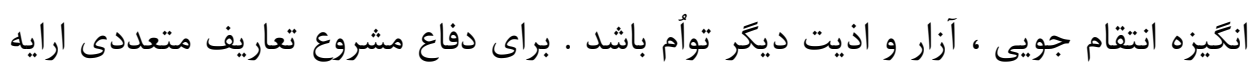

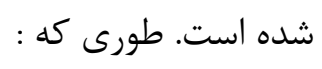
هركاه كسى كه به ناحق مورد حمله قرار گيرد براى دفع خطر، مرتكب جرم شود، در

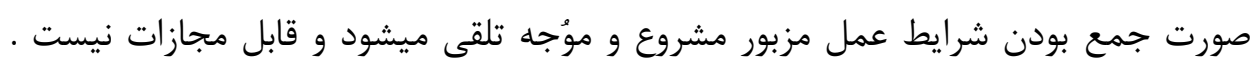

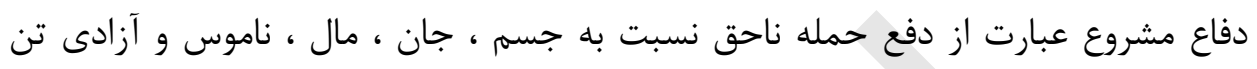
خود يا ديكرى در جار جوب قانون .(rسا) قانون جزاى افغانستان در تعريف ديكر دفاع مشروع يا دفاع قانونى عبارت است از توانايى بر دفع تجاوز قريب

الوقع و ناحقى كه نفس، ناموس، مال و آزادى تن خود يا ديخرى را به خطر انداخته است .

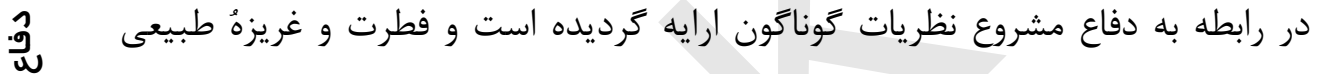

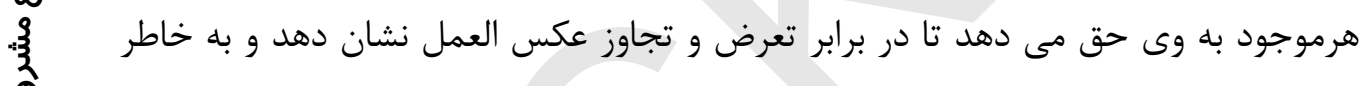

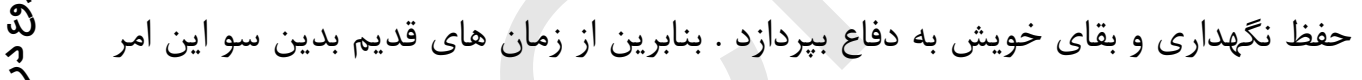

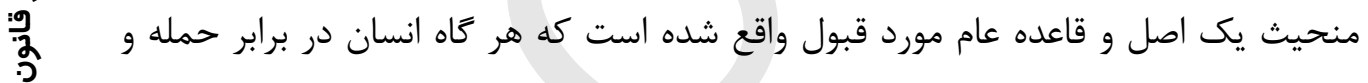

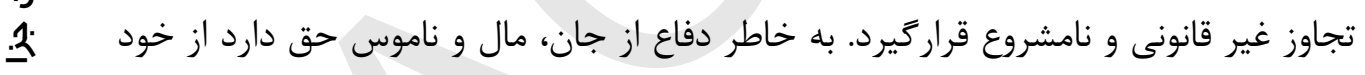
دفاع نمايد و اگر در جينين حالت مرتكب جرم گردد قابل مجازات دانسته نمى شود. دفاع امريست كه ريشهُ آن از بد و پيدايش آدمى موجود بوده و اين امر نه تنها منحصر به انسان بلكه در وجود تمام حيوانات نيز اين غريزه وجود دارد ـ به همين مناسبت در هركدام آن ها ساختمان فزيكى طورى تكامل نموده كه به نحوى قادر به دفاع از خود مى باشند ـ انسان منحيث موجود متكامل هستى و اشرف مخلوقات باداشتن قدرت تفكر و تدبر هنگام مواجه

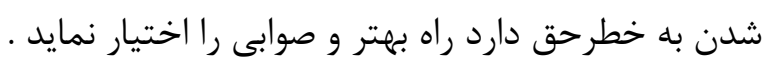

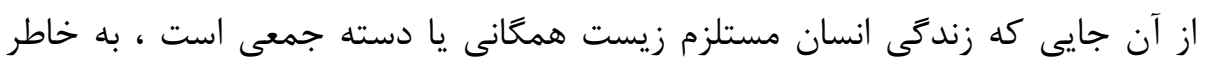
تنظيم بهترعلايق باهمى و حفظ حق بشرى در هر جامعه سيستمى به ميان آمده است كه

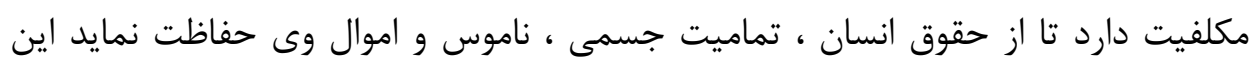


وظيفه خطير معمولاً بدوش اركان هاى حراست از حقوق يا يوليس ، مدعى العموم و قاضى

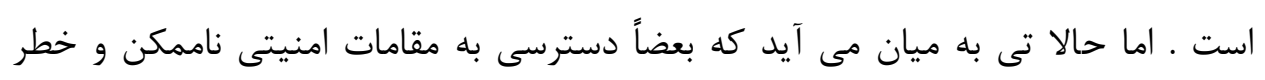

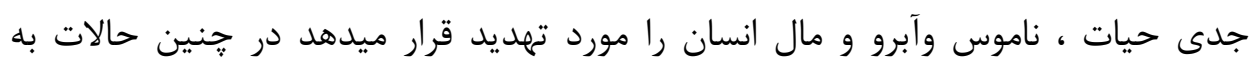

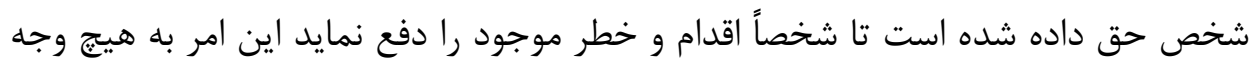

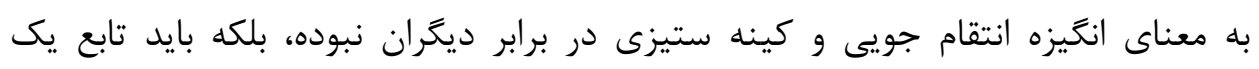

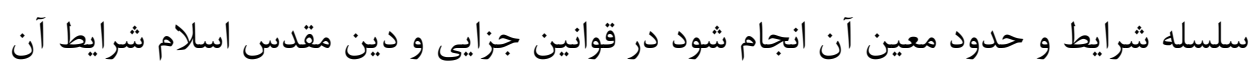

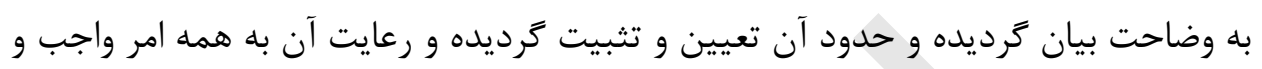
تجاوز از آن جرم بنداشته مى شود .

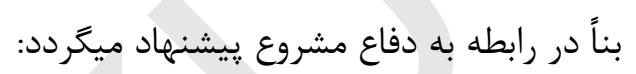
با در نظر داشت يرنسيب هاى قبول شده در قوانين جزايى دفاع صورت گيرد. تناسب دفاع با حمله جداً رعايت زردد. دفع حمله و تعرض به وسيله ديگر ممكن نباشد.

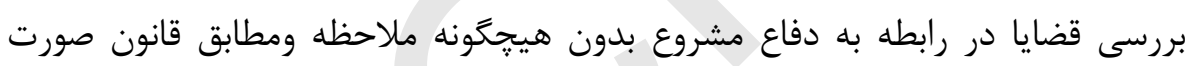

$$
\text { منابع } 1 \text { - قيرد. }
$$

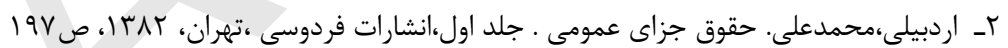

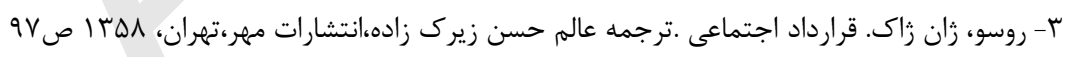

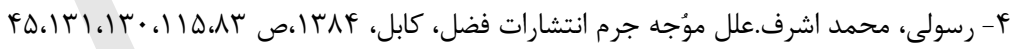

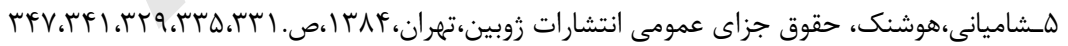

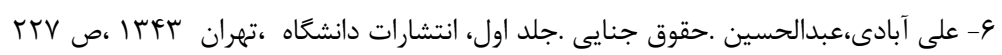

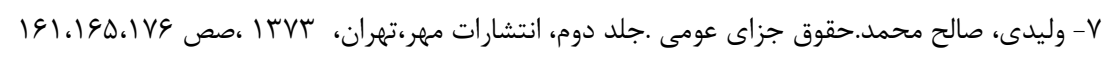

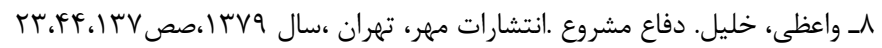

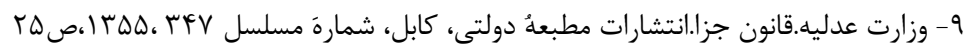

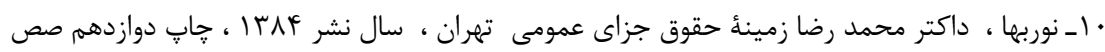

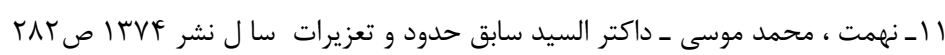

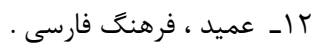

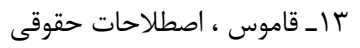




$$
\text { |- د اسلامى شريعت تاريخ }
$$

ترونونه او ميثاقونه

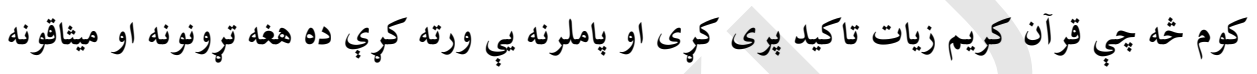

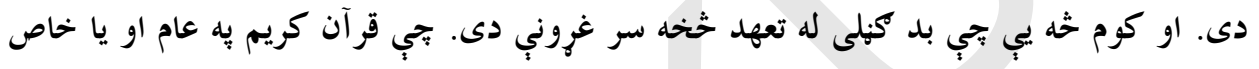

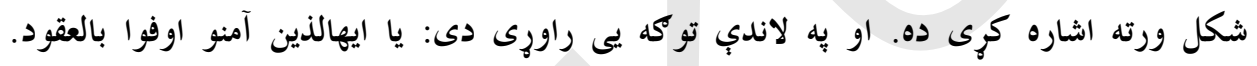

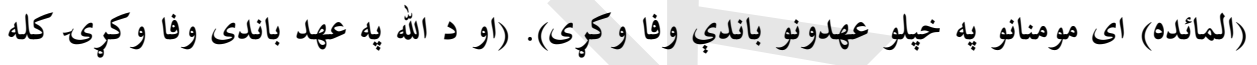

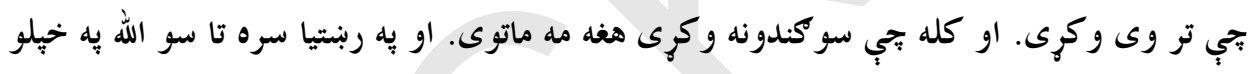

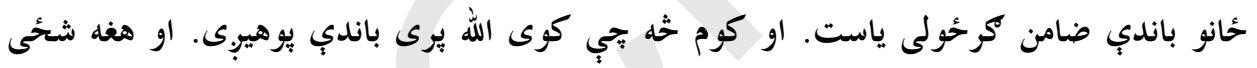

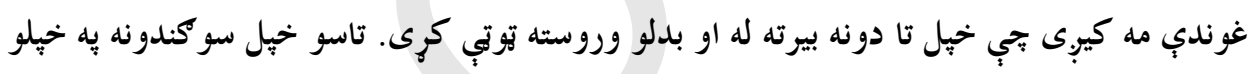

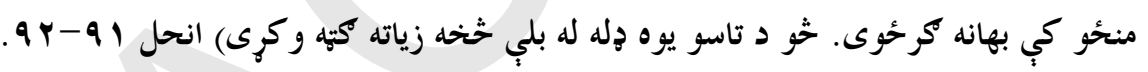

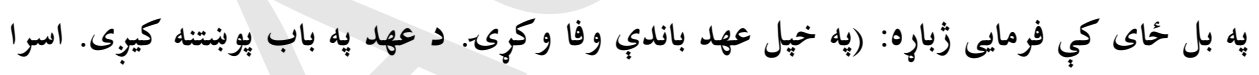

$r \varphi$

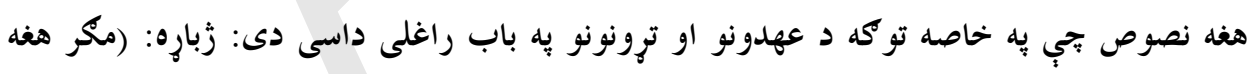

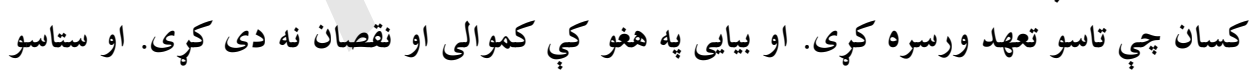

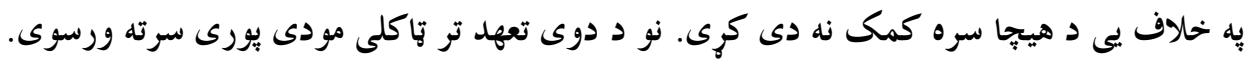

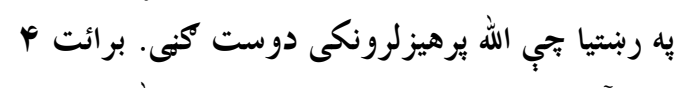

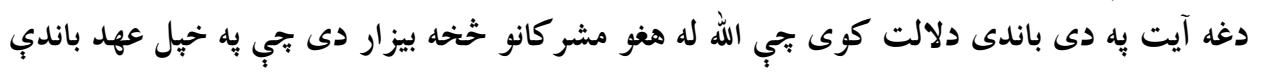

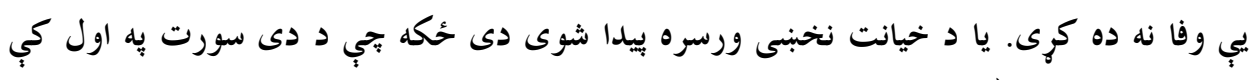

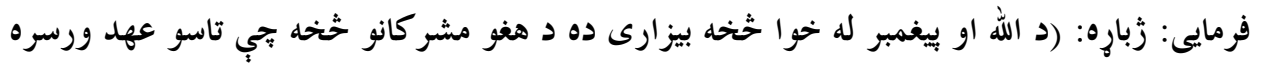


كرى دى.) بيا هغه تجب مخكي ياد شوى دا بيا ترى جلا شوى دى. او دا د هغه حكم به حخاى كول

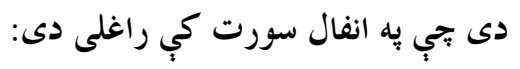

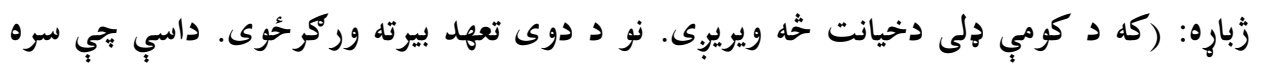

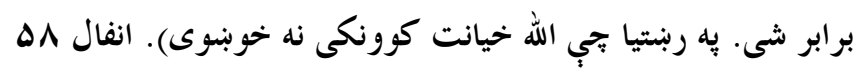

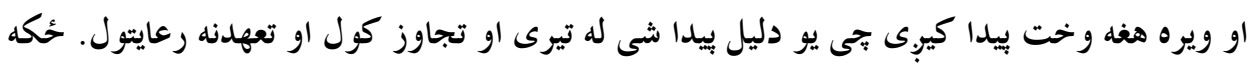

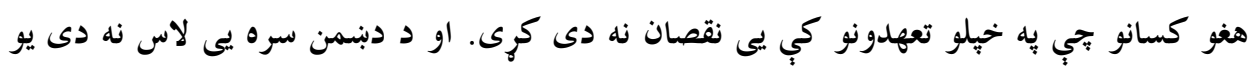

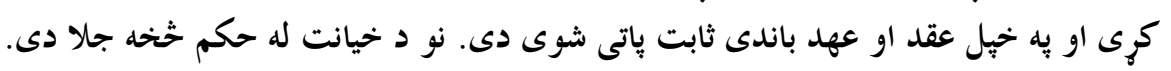

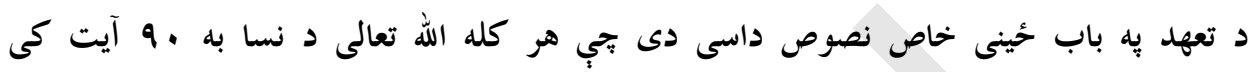

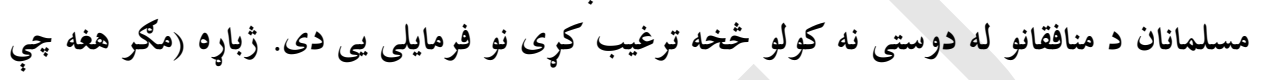

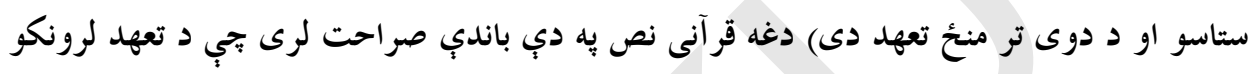

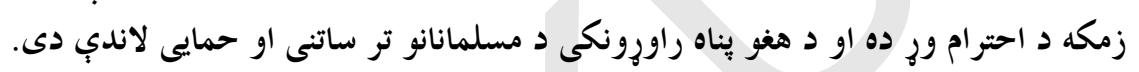

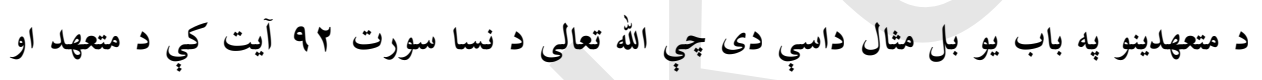

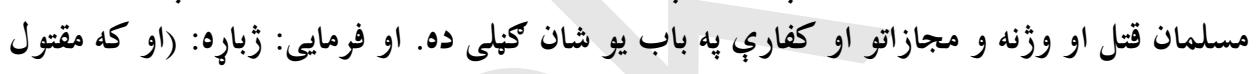

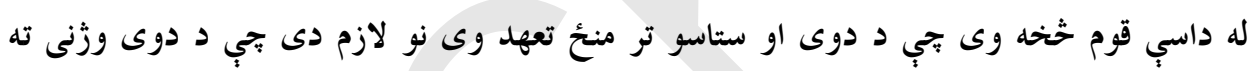

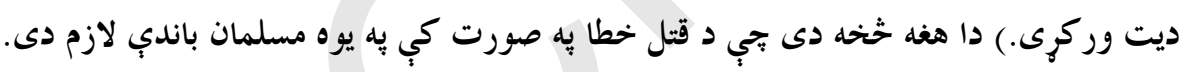

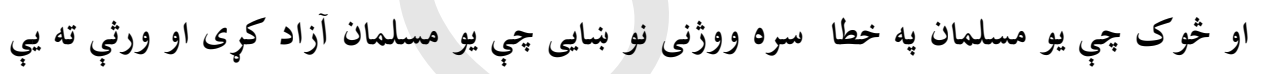

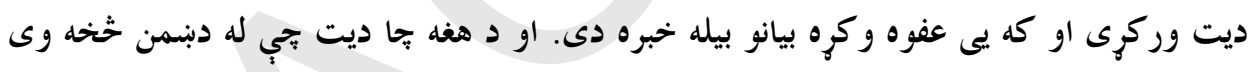

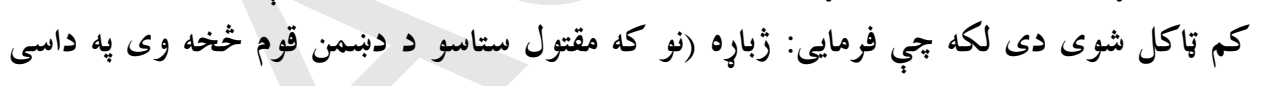

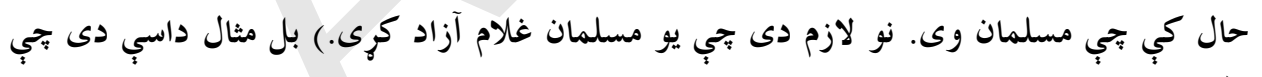

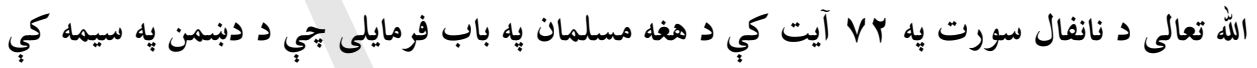

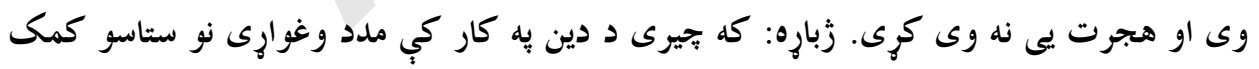

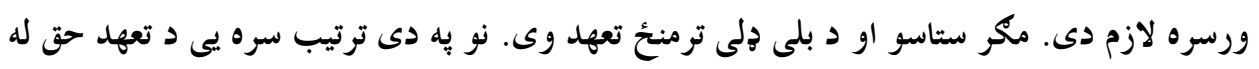

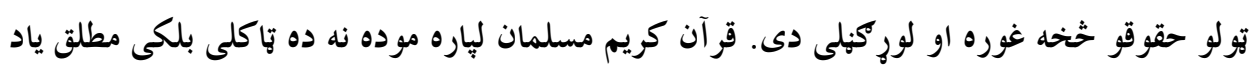

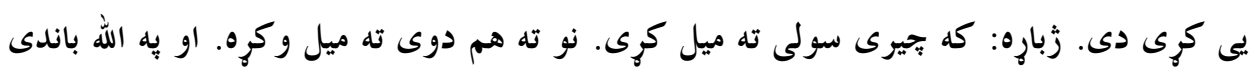

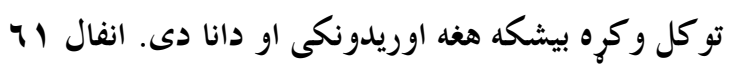
د جنك اسيران 


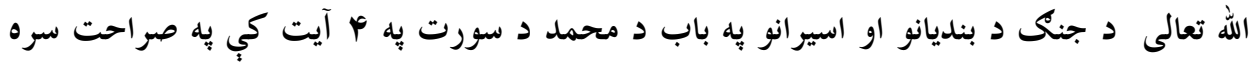

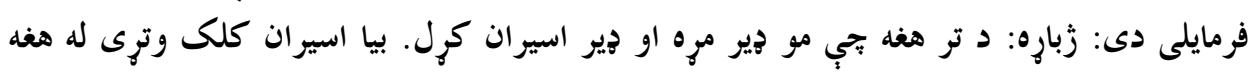

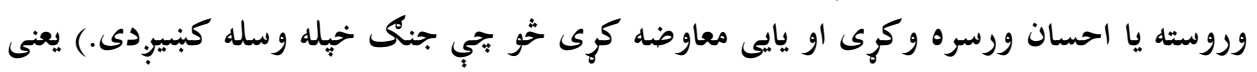

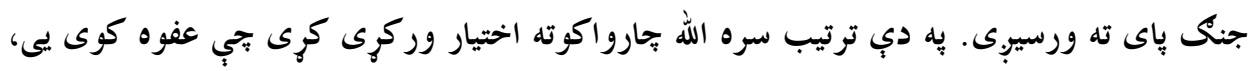

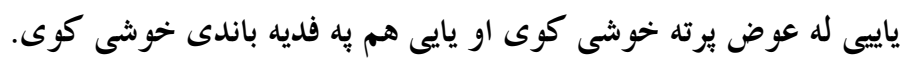

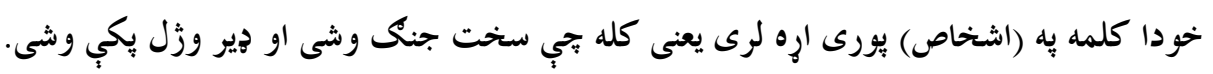

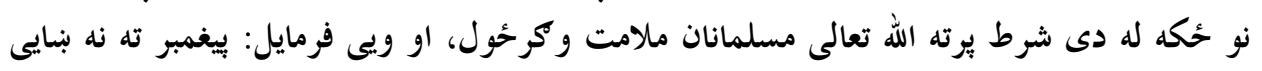

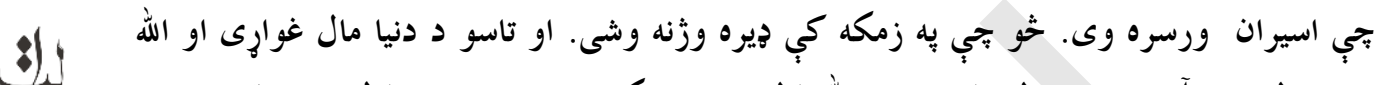

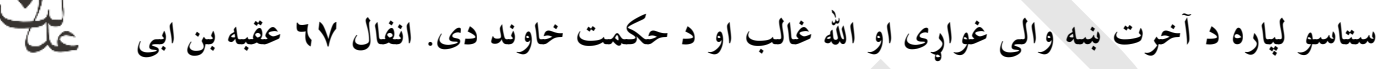

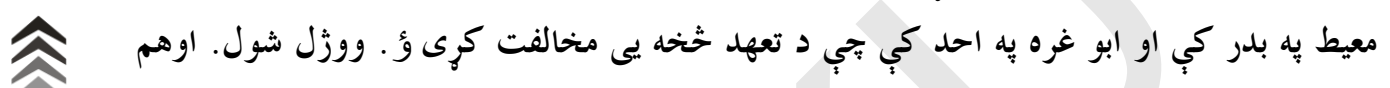

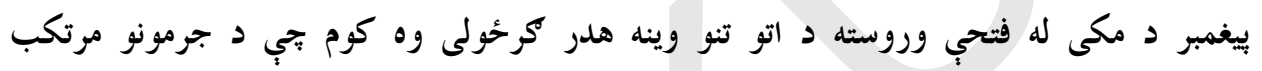
كر حيدلى وو.

\section{د غلامى به باب د اسلام دريخ}

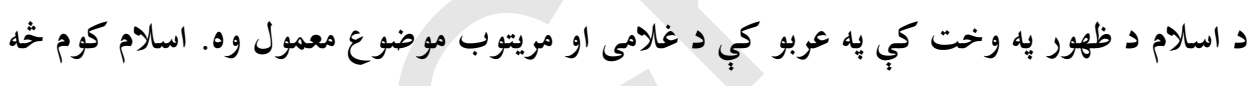

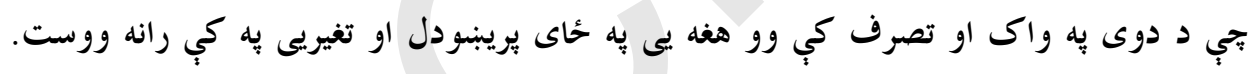

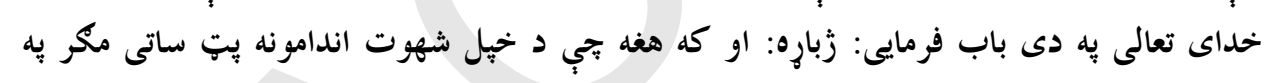

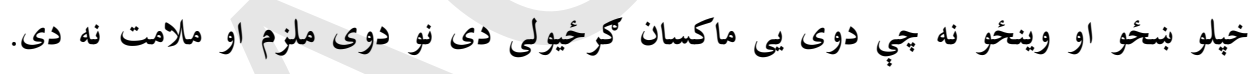

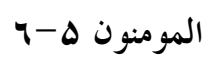

همدارنكه د معارج به سورت كي تجي د جنك او قتال خخه د مخهل يق فرمايلى وو همدا حكم لرى.

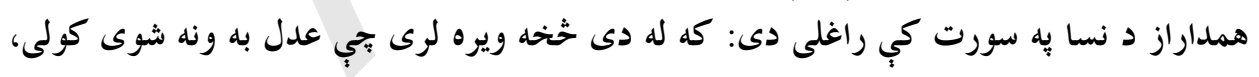
بنتخه پِه نكاح كرى يا وينحه تجي ستاسو تر لاس لاندى وىى. بيا قر آن كريم د دي ترغيب او تشويق

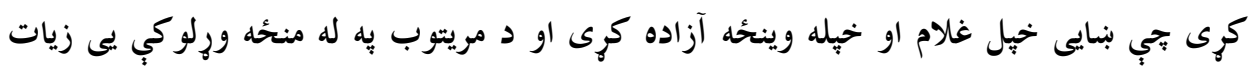

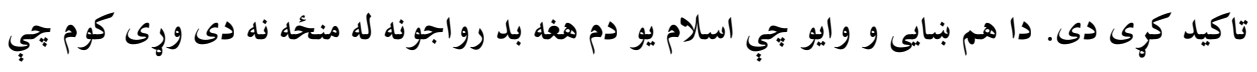

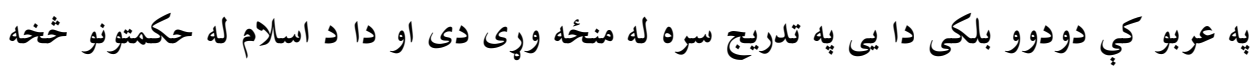

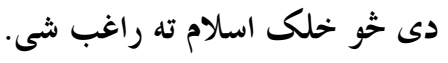


د انسان آزادول اسلام له خهلو واجباتو خخه وكنبل او هغه كسان تب دا كار كوى دوى يى د اجر

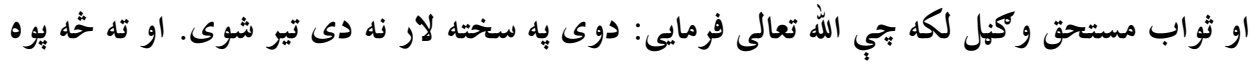

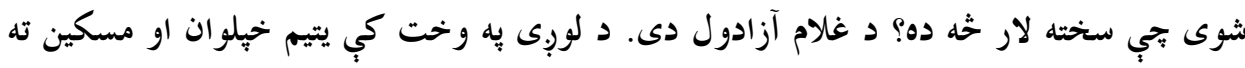

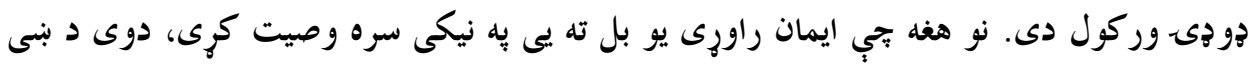

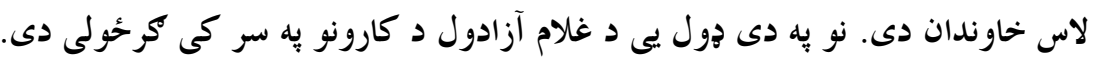

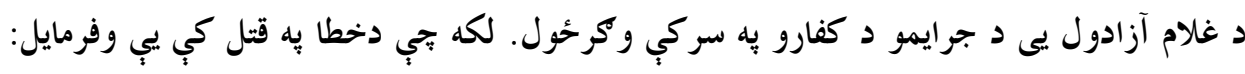

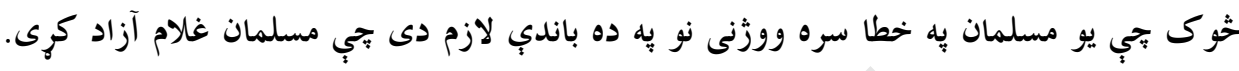

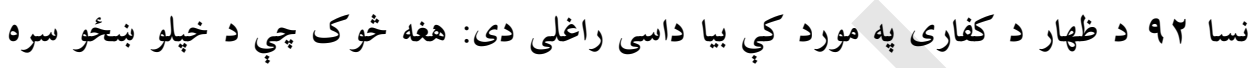

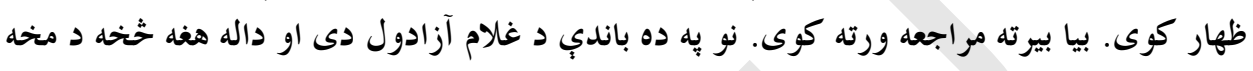

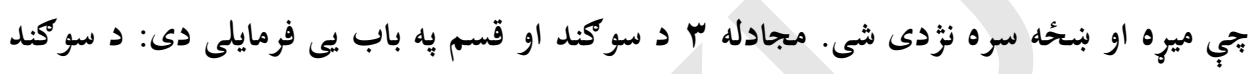

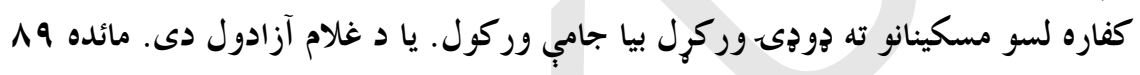

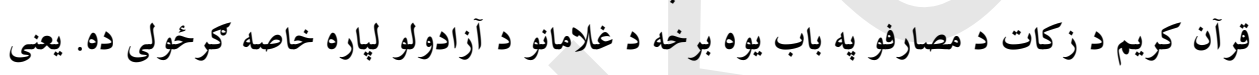

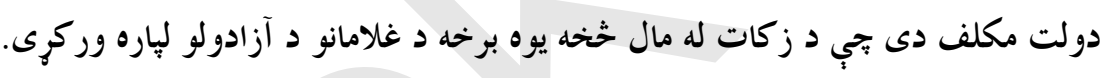

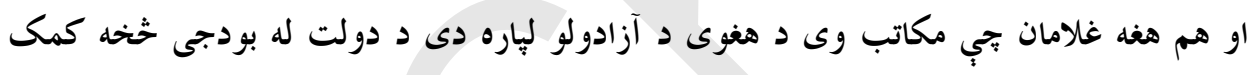

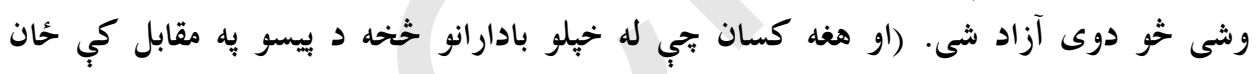

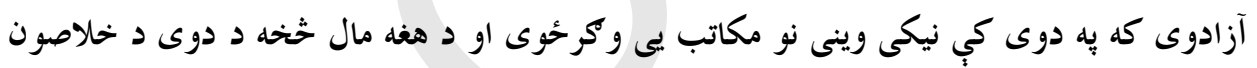

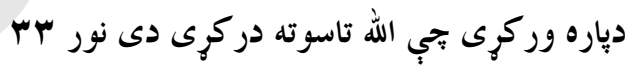

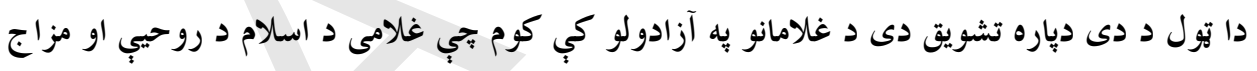

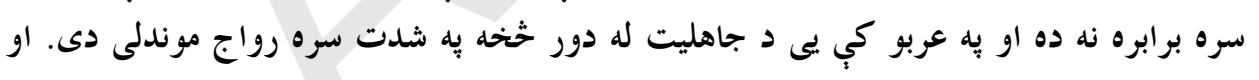

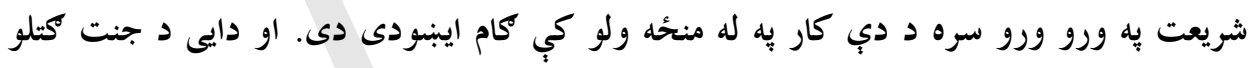

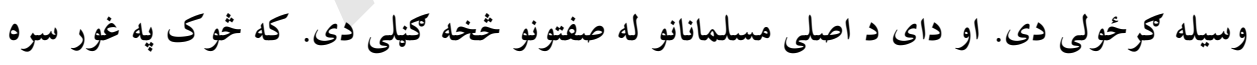

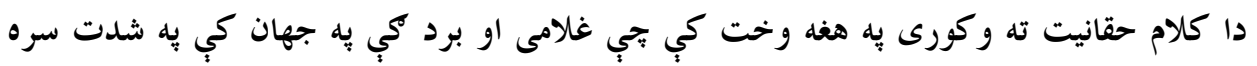

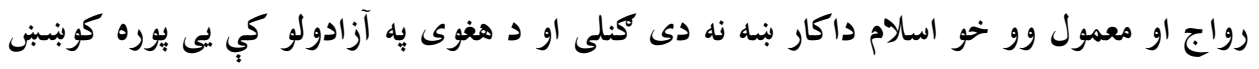
كرى دى. د جنك غنيمتونه

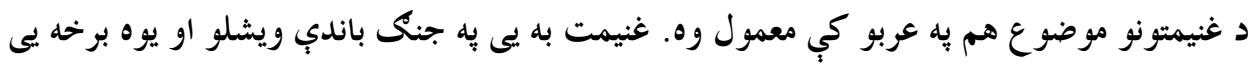

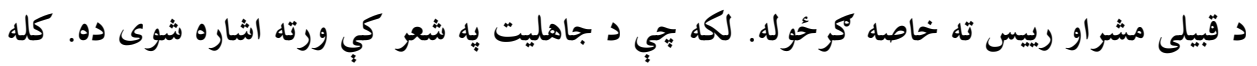


تجب اسلام ظهور وكر هغه لومرى غنيمت تب د مسلمانانو لاس ته ولويد هغه د بدر د غزا غنيمت

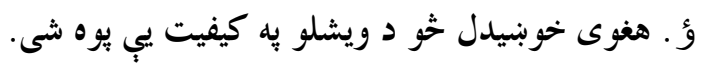

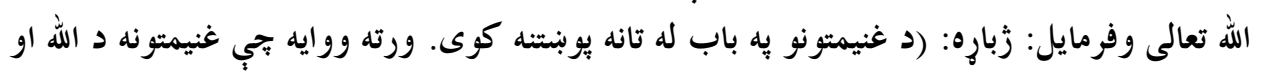

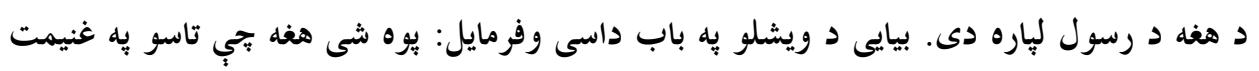

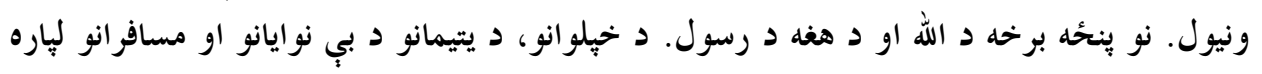

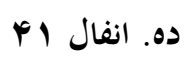

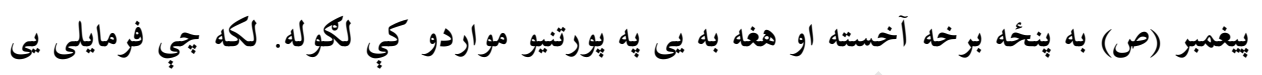

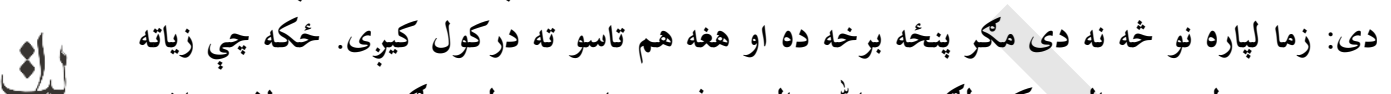

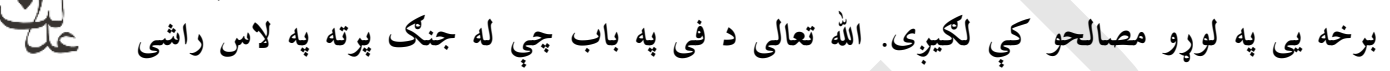

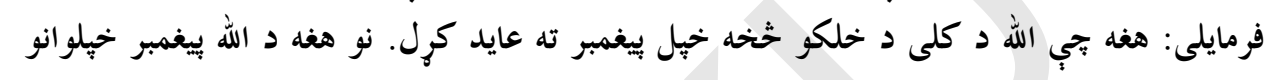

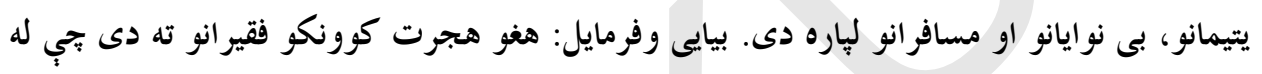

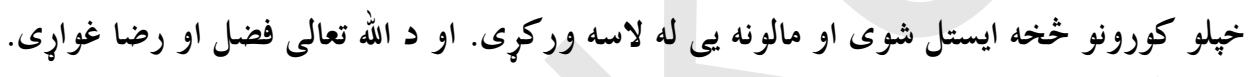

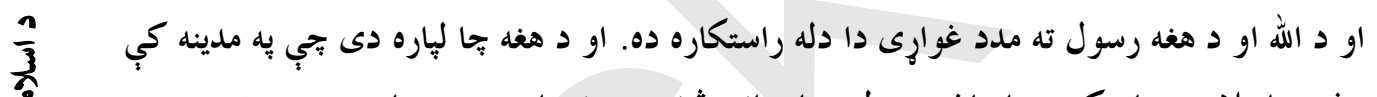

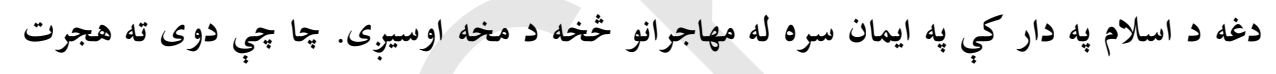

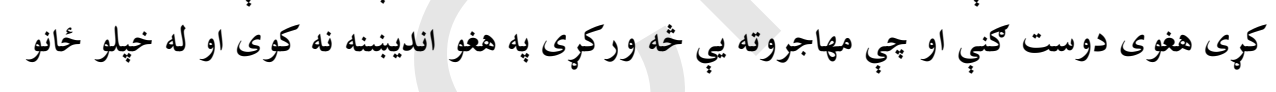

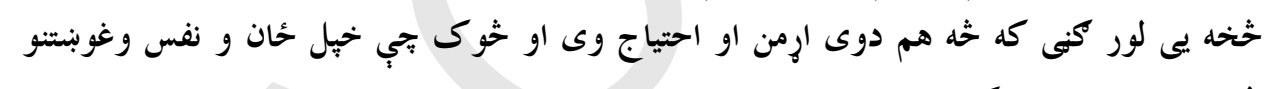

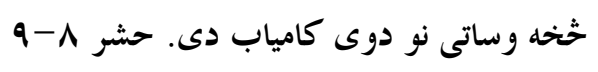

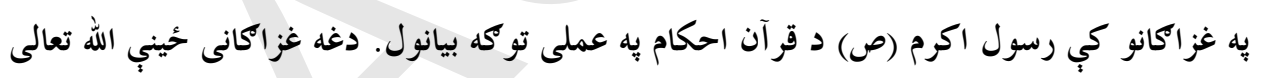

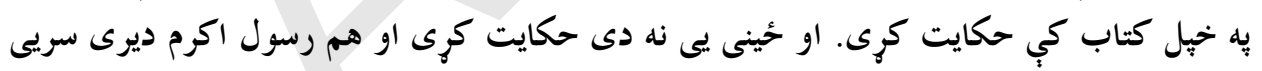

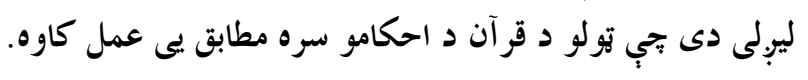

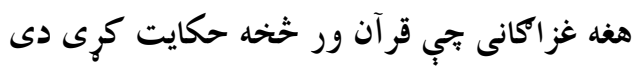

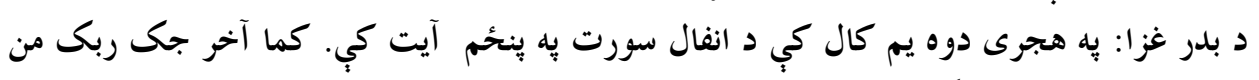

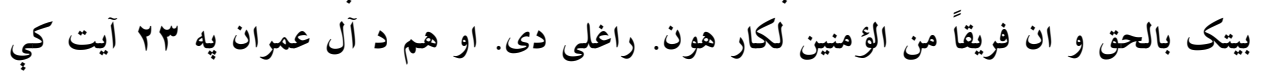

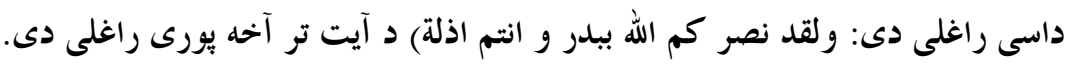

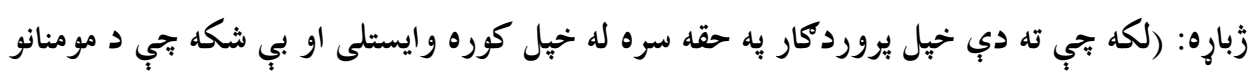

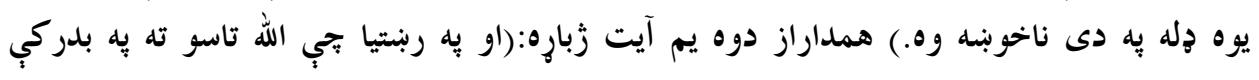

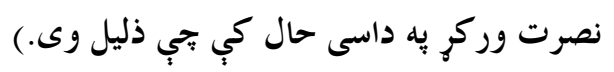


د احد غزا: يه دريم هجرى كال كي يى صورت موندلى دى. د آل عمران هب آ آيت تر آخره يه

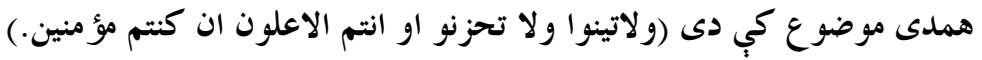

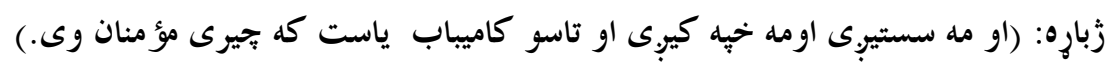

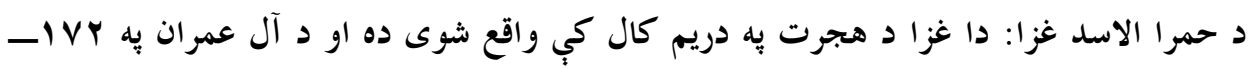

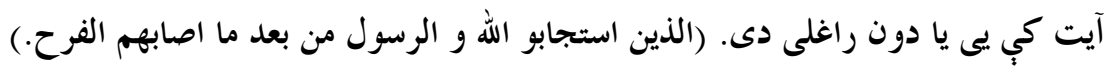

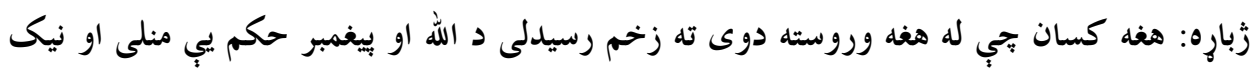

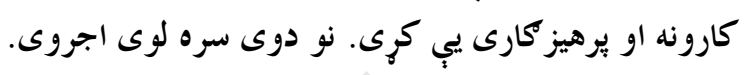

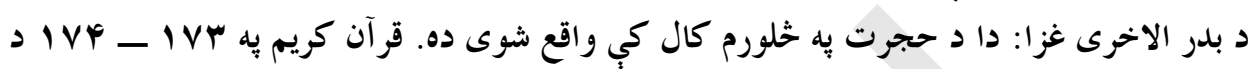

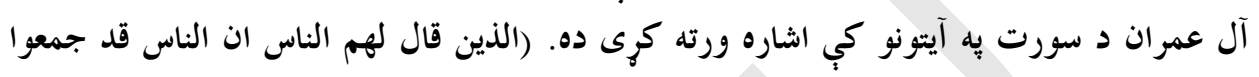

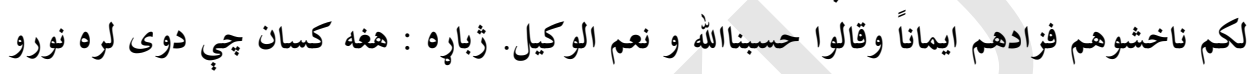

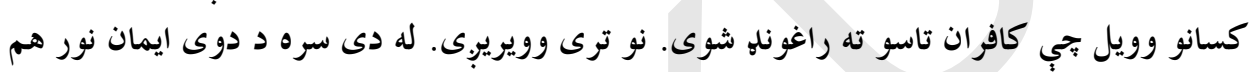

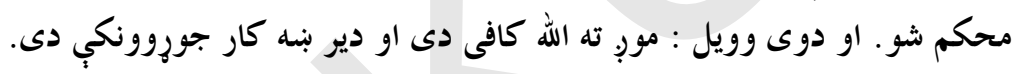

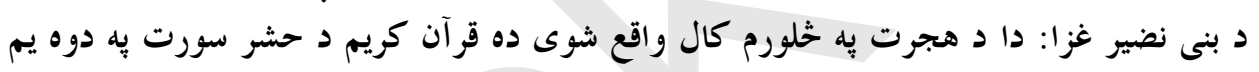

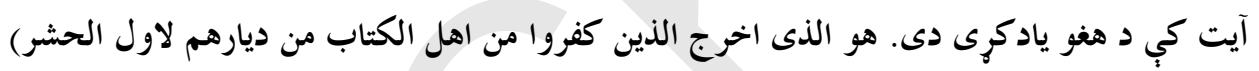

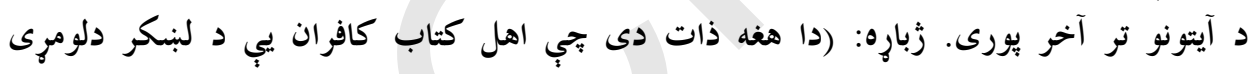
غونديدو لِاره له كورونو خخه وايستل)

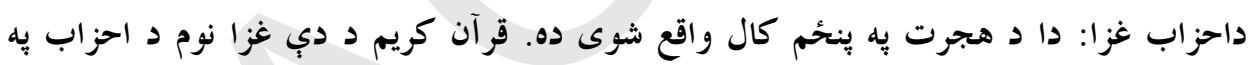

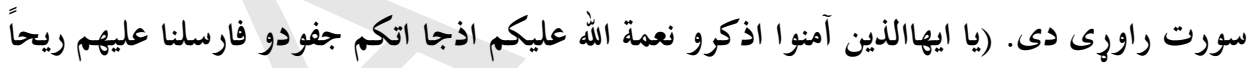

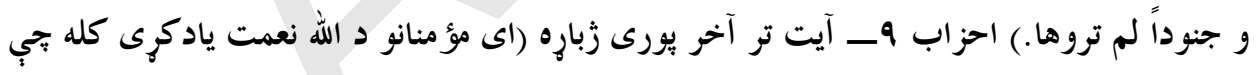

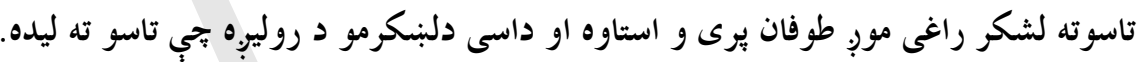

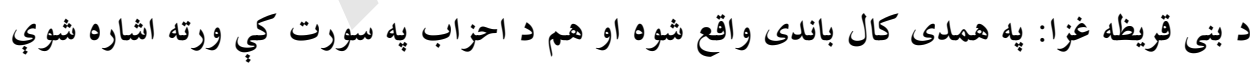

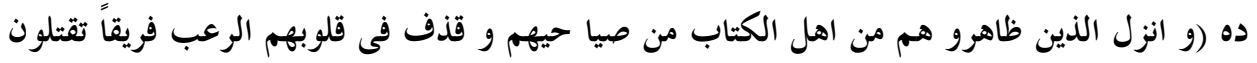

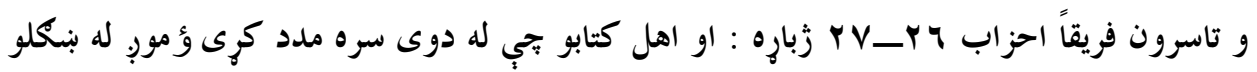

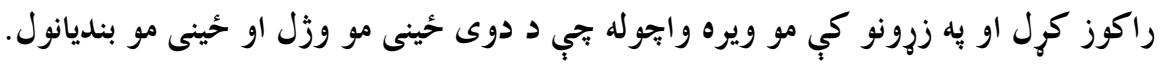

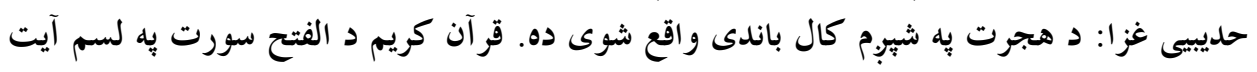

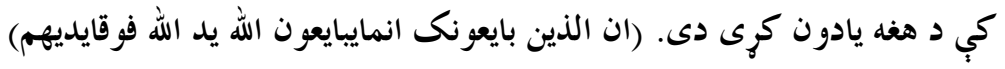




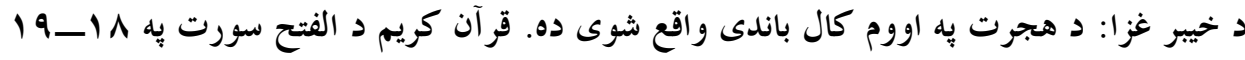

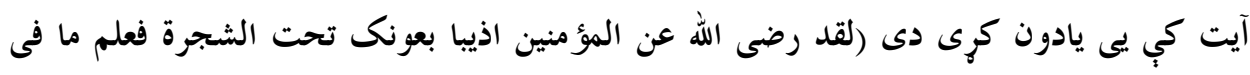

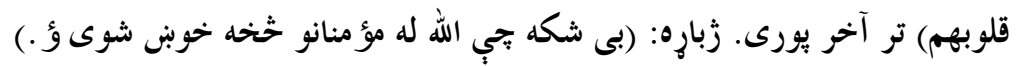

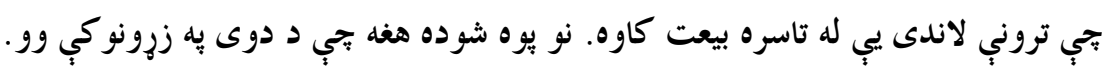

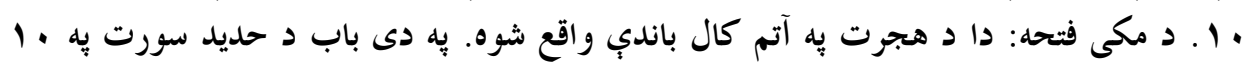

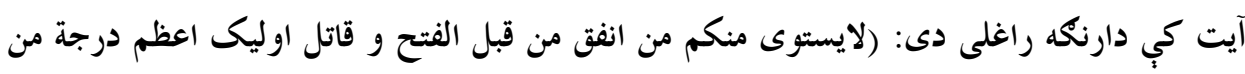

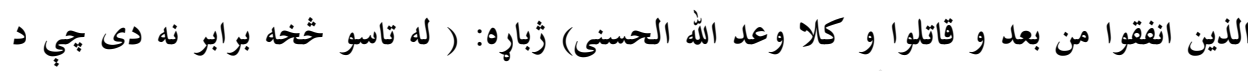

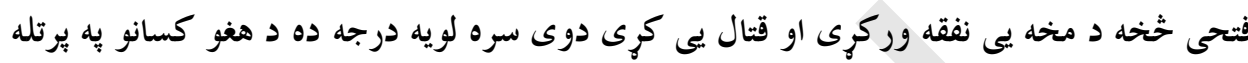

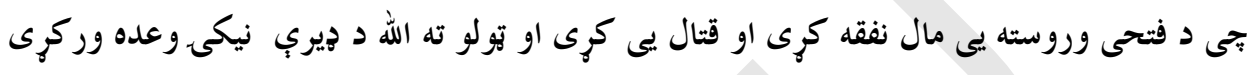

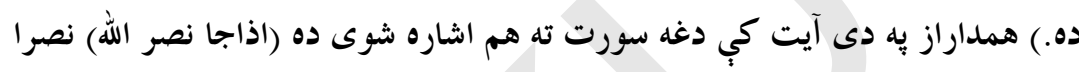

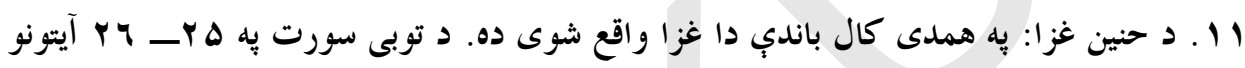

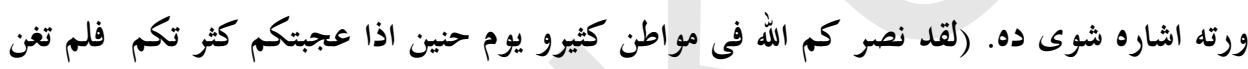

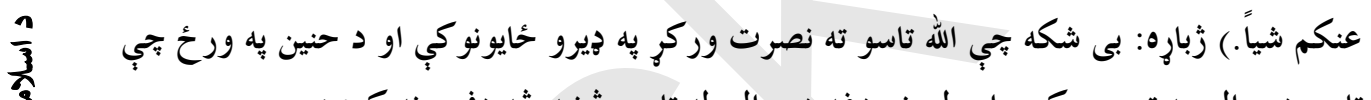

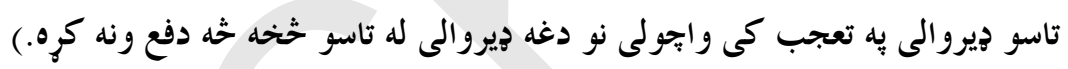

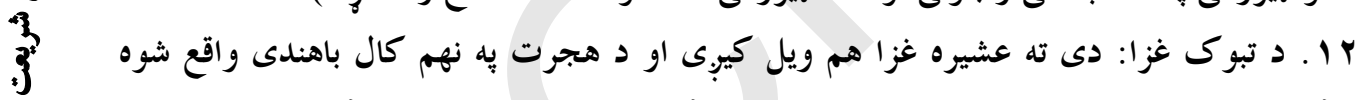

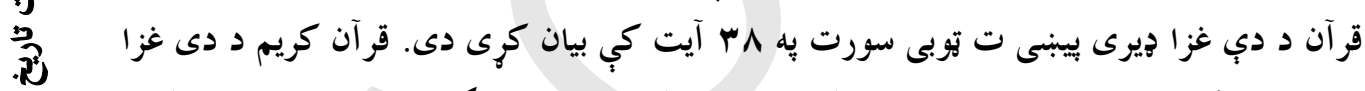

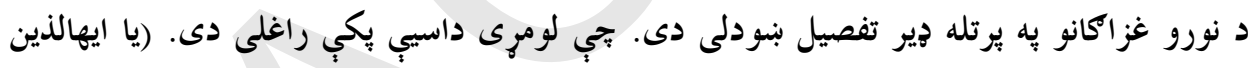

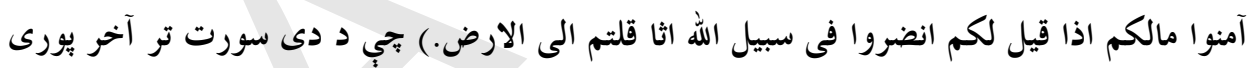

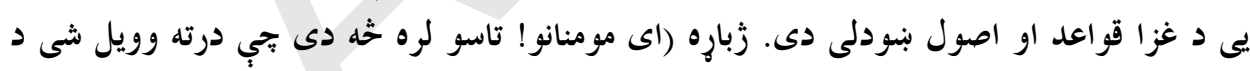

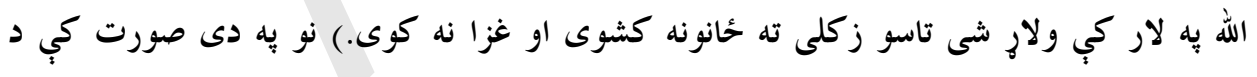

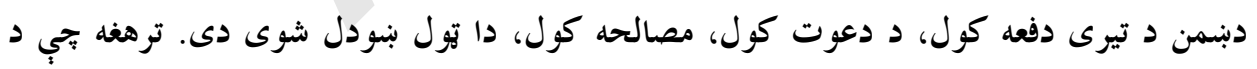

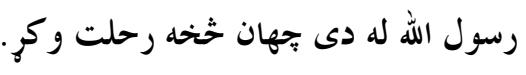

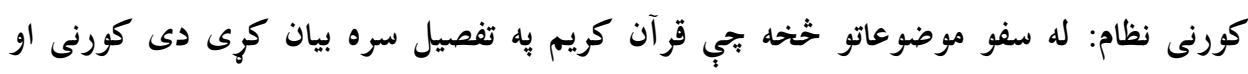

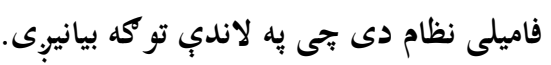

ازودواج قر آن كريم ازدواج مشروع كرحولى او د ازدواج عقد يب محكم او كلك سبر بللى دى. لكه يّب

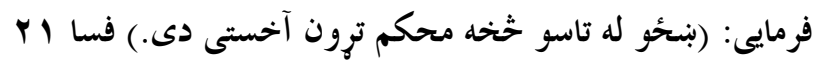


اسلام د ميره او بندئى د دوستى به تينكبندت باندي امر كرى دى.

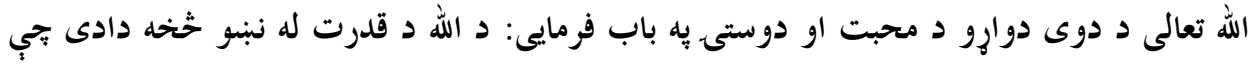

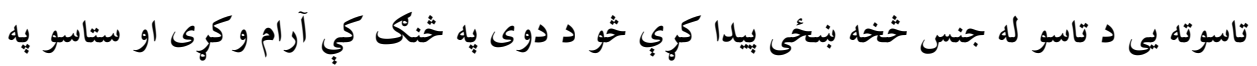

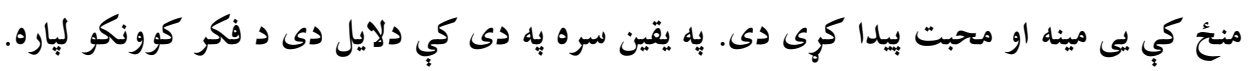

روم إن

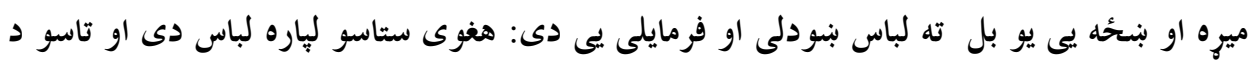

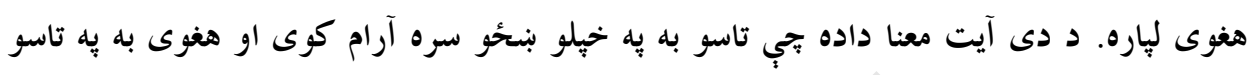

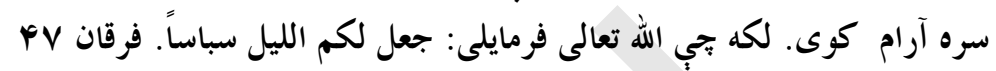

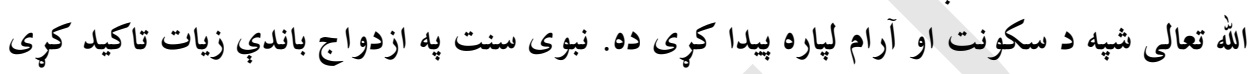

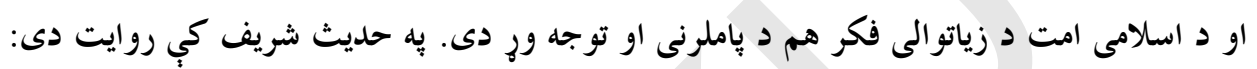

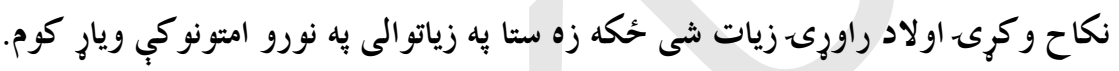

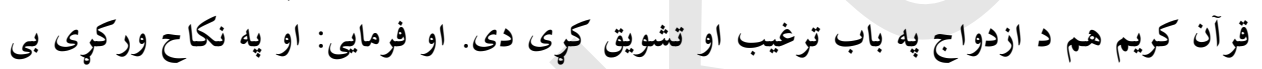

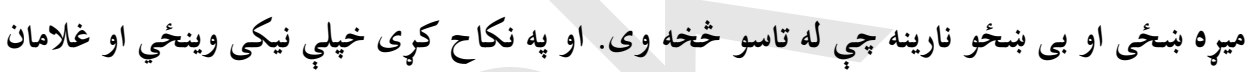

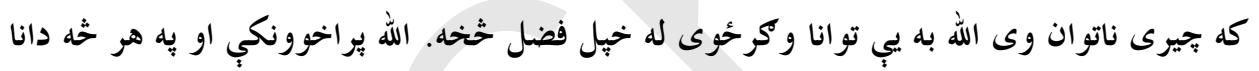
دى) نور بr

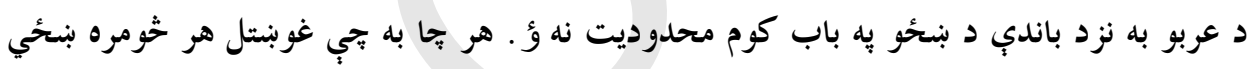

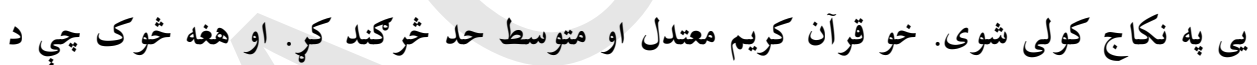

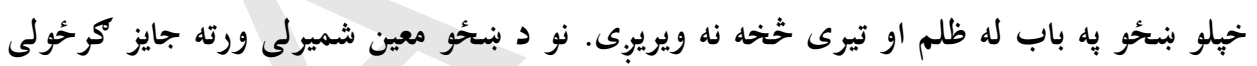

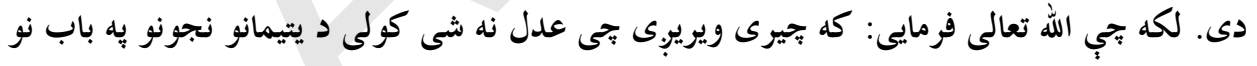

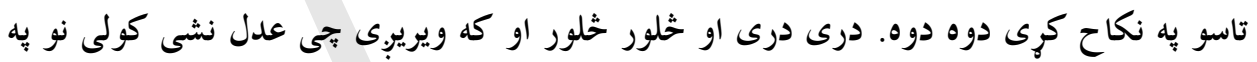

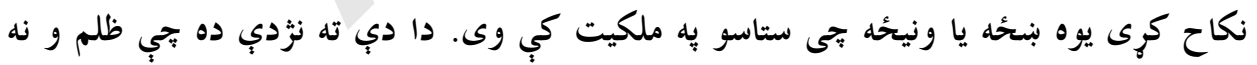

$$
\text { كرى. نساء }
$$

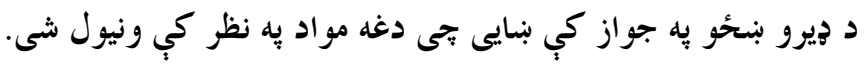

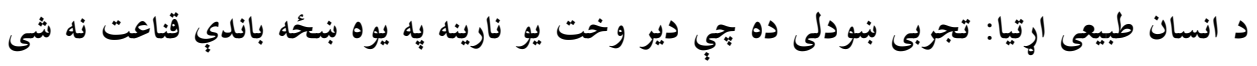

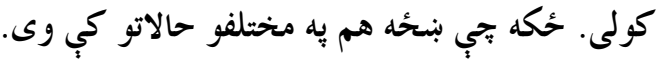

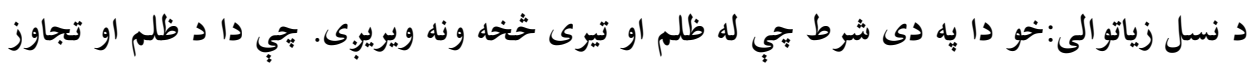

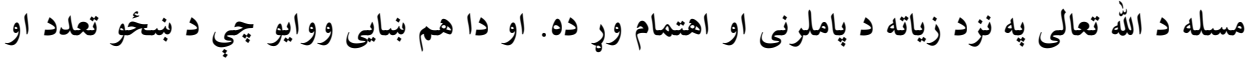


ديروالى د شريعت له نظره له اساسى او ضرورى امرونو خخه نه دى. بلكى دا يو مباح كار دى جب إي

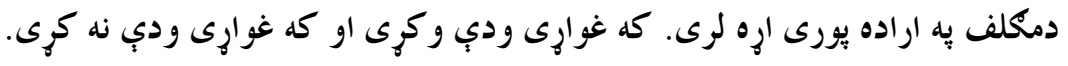

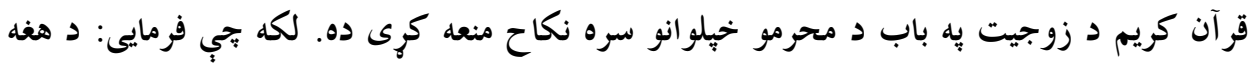

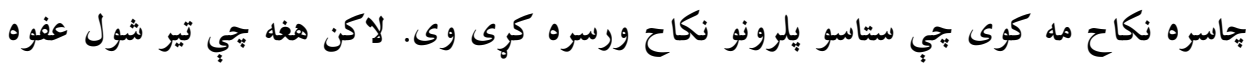

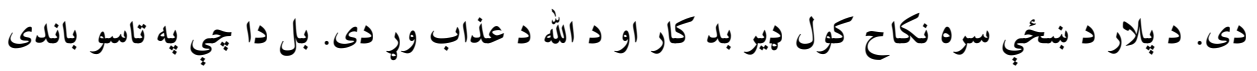

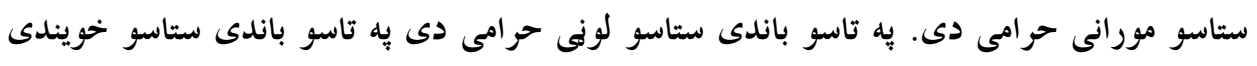

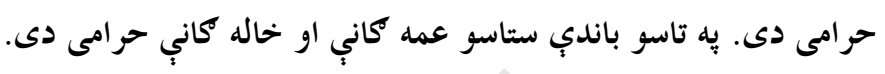

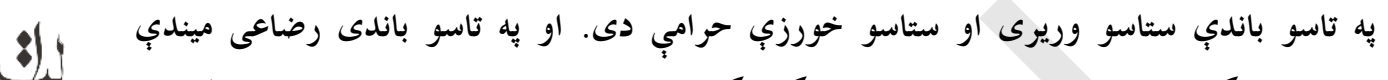

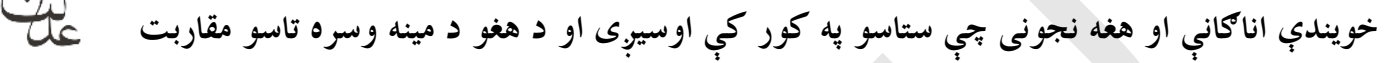

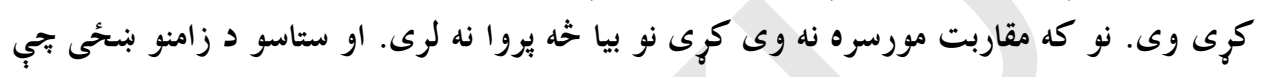

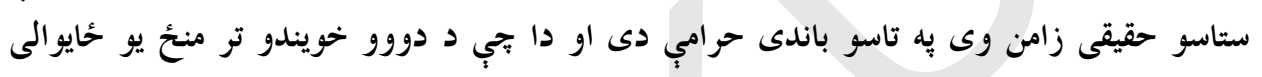

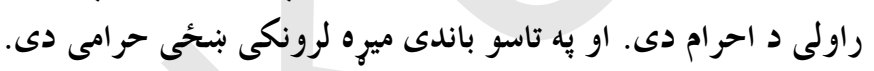

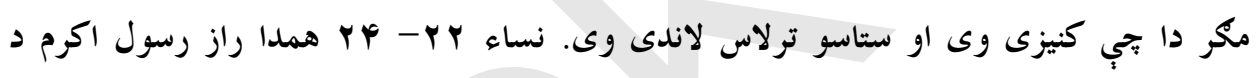

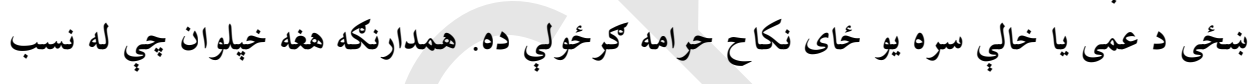

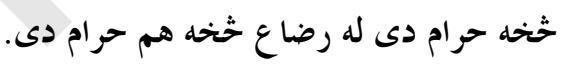

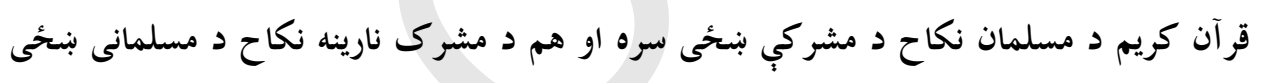

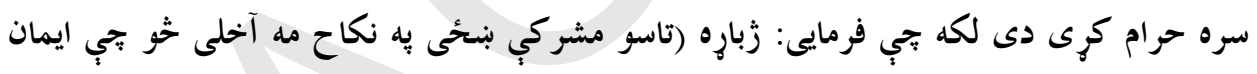

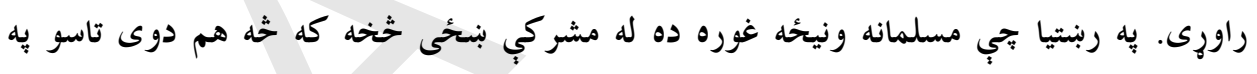

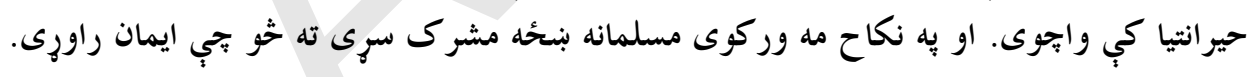

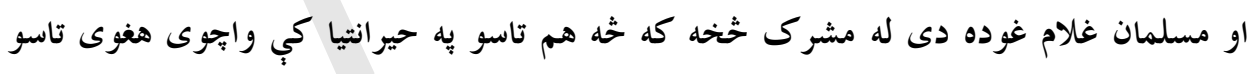

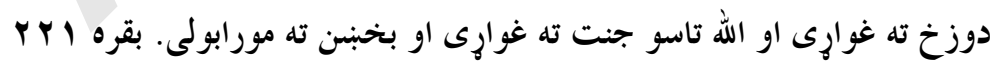

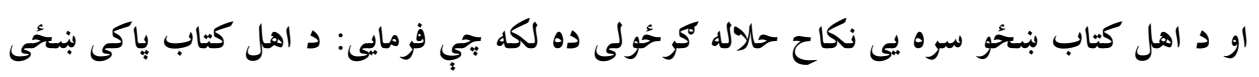

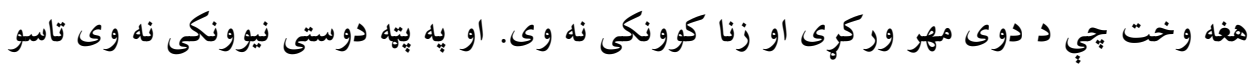
ته حلالى دى. مائده هـ

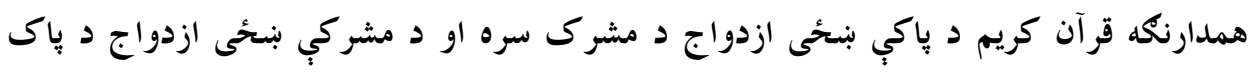

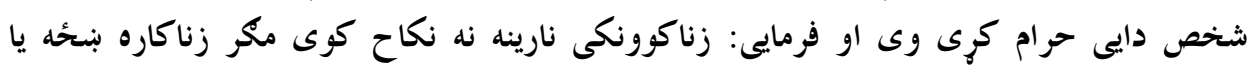


مشر كه او زناكاره بنحُه نه نكاح كوى مكر زنا كوونكى نارينه يا مشرك او دا به مومنانو باندى

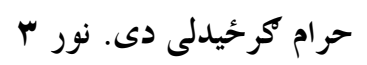

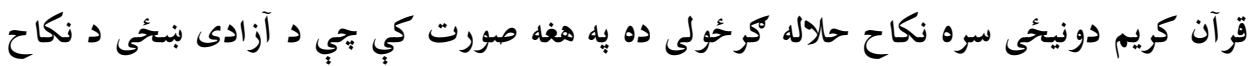

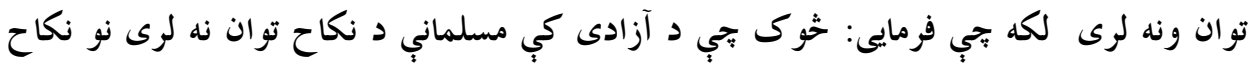

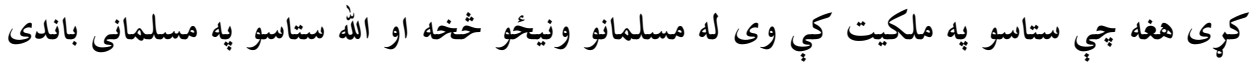

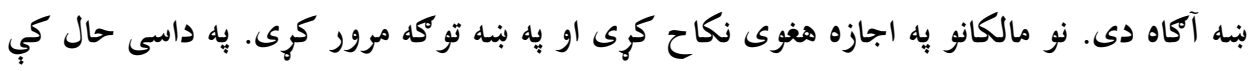

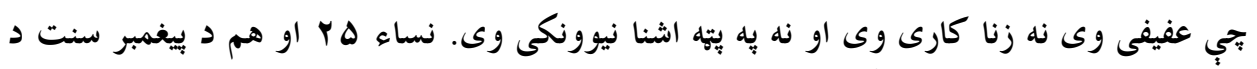

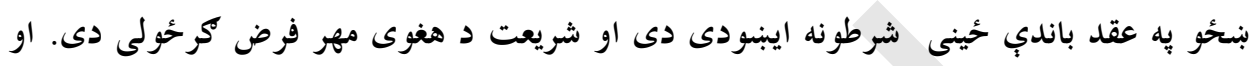

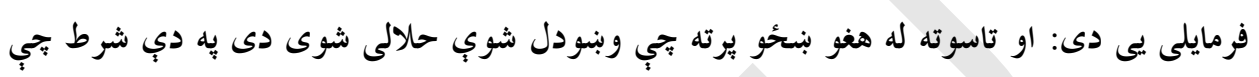

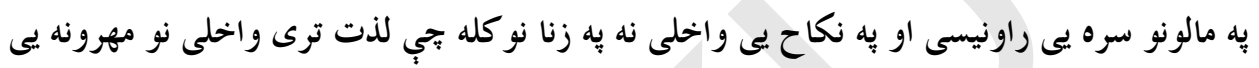

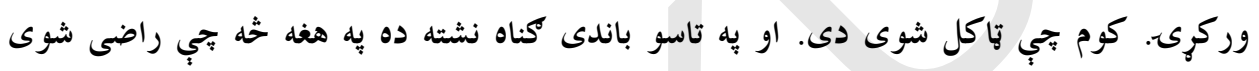

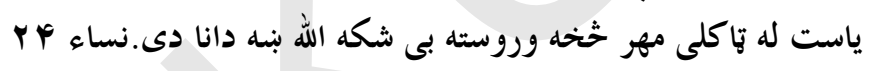

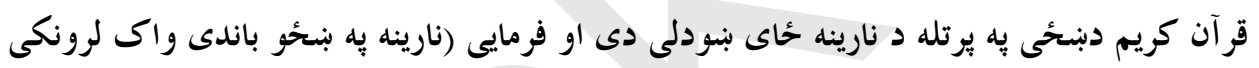

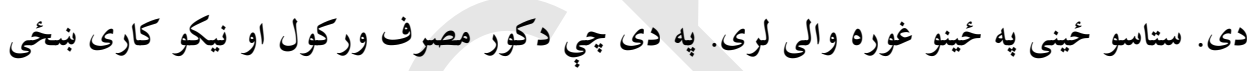

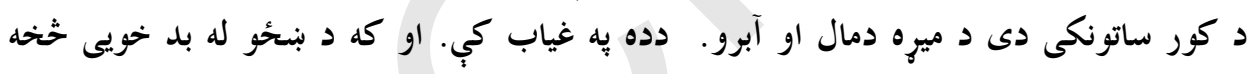

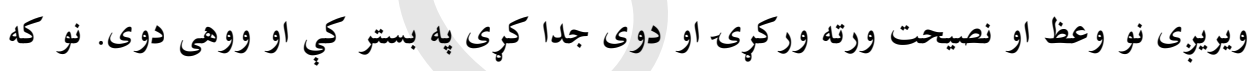

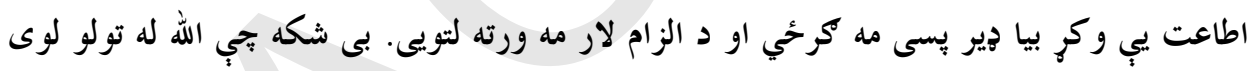

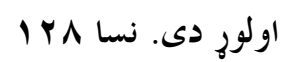

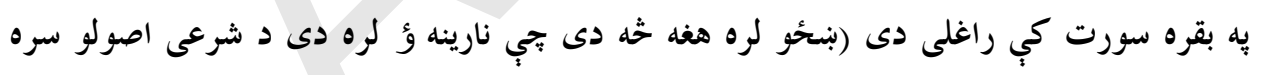

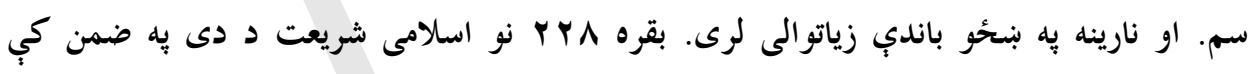

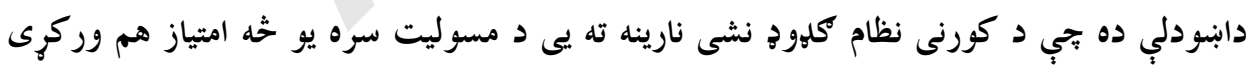

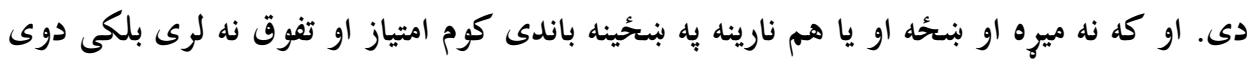

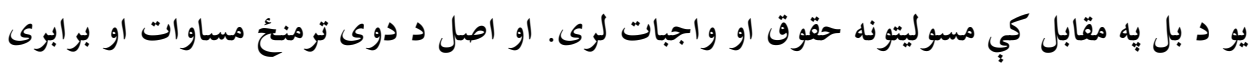

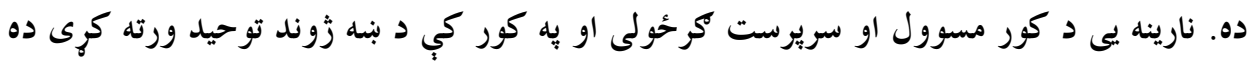

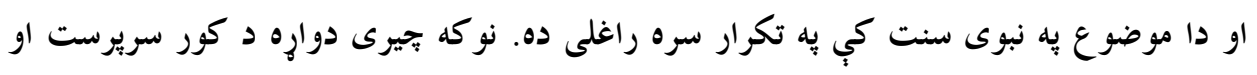

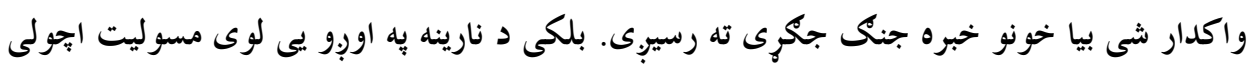

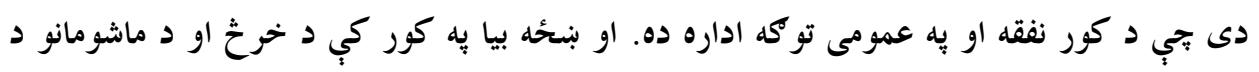


ادارى او تربي مسووله ده. نو يه دي ترتيب سره د دوارِو دندي او وظيفب سره جلا او د اهميت

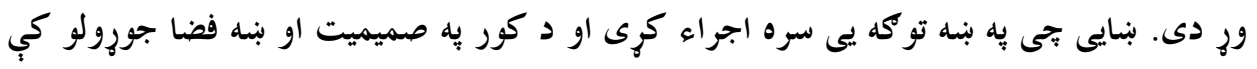
دواره مهم رول ولوبوى دئ.

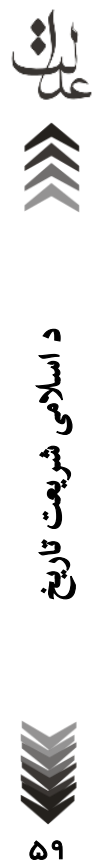

จ१ 


\title{
قاتونكذارى از ديدكاه اسلام
}

\author{
قسمت اول
}

III

مقدمه

نخستين برترى قوانين اسلامى نسبت به ديگر قوانين ، اعم از قديم وجديد ، شرقى

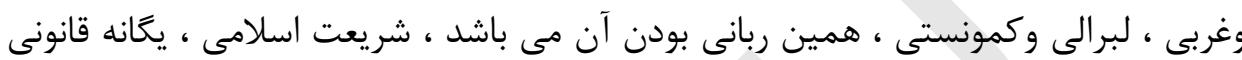
است كه اساس آن ييام خداوند(جل جلاله ) واحكام راستين وعادلانه وى مى باشد. برهمين اساس ازجمله اصول استوار و يذيرفته شده اسلامى اينست كه يخانه قانونكذار وتشريع كننده خداوند(جل جلاله ) ميباشد، اوست كه به اقتضاى ربوبيت، الوهيت وملكيت خودبه تمامى آفريده هاى خود، امرونهى ميكند، حلال وحرام را تعيين مى نمايد ووظيفه وتكليف را مشخص ميكند.

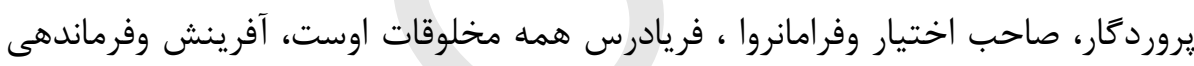
وحق قانونكذارى از آن اوست ، حكم وحكمرانى دراختيار اوست . احدى غير ازاو حق تشريع وقانونخذارى را ندارد ،مكر درزمينه اى كه نص قاطع درآن زمينه وجود نداشته باشد ، كه جنين كارى درحقيقت اجتهاد واستنباط وشيوه گزينى است، در شريعت اسلام حتى خود يِامبر (صلى الله عليه وسلم ) هم تشريع كننده و هم قانونكذار مستقل نبود ، بلكه اطاعت از وى به اين دليل واجب شده كه وى پيام آور وپيام رسان خدواند متعال مى باشد. 
وبه همين دليل فرمان وى ناشى از فرمان خداوند متعال ميباشد. خداوند (جل جلاله )

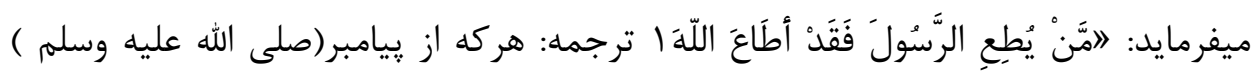

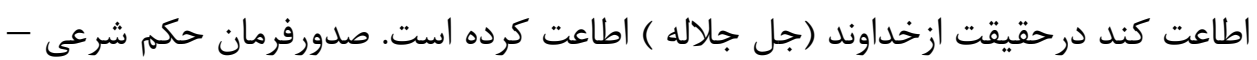

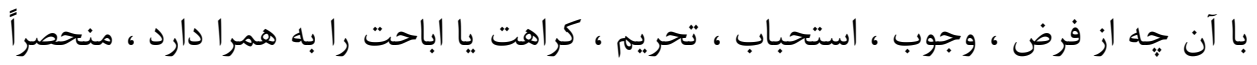

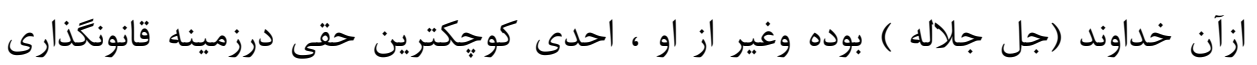

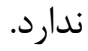
قرآن كريم كه اولين واساسى ترين منبع قانونگذارى درنظام حقوقى اسلامى مى باشد

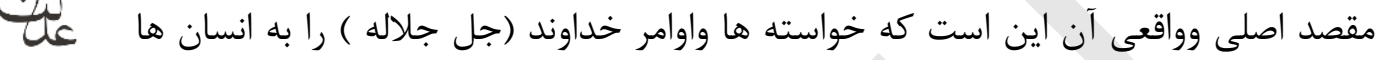
ياد داده وبه بيان راهاى بيردازد كه يك سلمان با يِيمودن آن ميتواند مسلمان خوبى شود وبه خوشبختى دنيا وآخرت نايل آيد. منابع قانونخذارى درنظام حقوقى اسلام. منظوراز منابع درنظام حقوقى اسلام دلايل شرعى مى باشد كه احكام شرعى از آنها استنباط ميشود اين منابع از نقطه نظر علم اصول فقه به دودسته تقسيم شده اند كه عبارت از منابع مورد اتفاق ومنابع مورد اختلاف مى باشد دراين بحث نخست پِيرامون منابع مورد اتفاق سيس درمورد منابع مورد اختلاف بين فقها درزمينه قانونگذارى درنظام حقوقى اسلام

$$
\text { توضيحات ارائه مى گردد. }
$$

الف - منابع مورد اتفاق : منابع مورد اتفاق درنزد فقها عبارت است از:

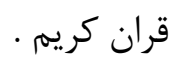

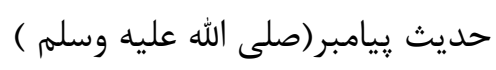

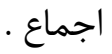

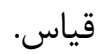

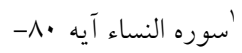

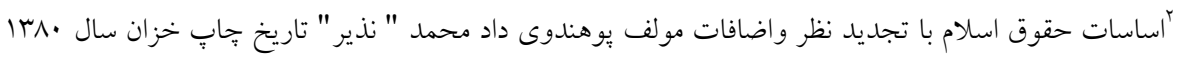




$$
\begin{aligned}
& \text { ب - منابع مورد اختلاف درنزد علماء عبارت است از: } \\
& \text { استحصان } \\
& \text { مصالح مرسله }
\end{aligned}
$$

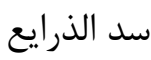

$$
\begin{aligned}
& \text { قول صحابه } \\
& \text { عرف . } \\
& \text { شرايع آسمانى قبلى }
\end{aligned}
$$

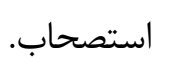

اول- قرآنكريم : قرآن كريم آخرين كتاب الهى است كه خداوند(جل جلاله ) توسط

حضرت جبرائيل امين ريغمبر (صلى الله عليه وسلم ) به انسان ها تعليم داده شده است تا به به

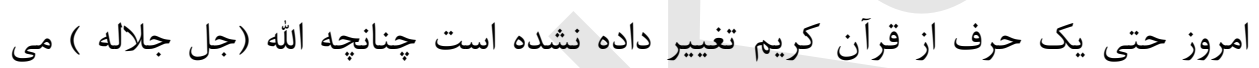

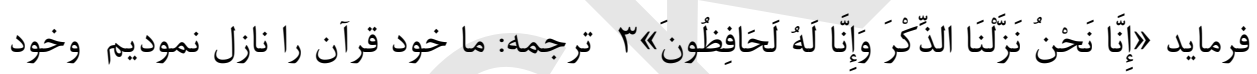
ما ياسدار آن ميباشيم وتا روز قيامت آن را ازدست برد دشمنان واز هركونه تغيروتعديل محفوظ ميداريم ع قرآنكريم بعد از نازل شدن توسط صد ها حافظ از حفظ يا از بر مى شد رئم وكروهى هم آن را مى نوشتند ونكَهدارى مى كردند نخستين نسخه خطى قر آنكريم فعلاً هم درقصر" توף كإيى" درتركيه نتخهدارى ميشود. امروز درتمام نقاط دنيا ودرهمه كشورها مسلمانها هستند وقرآنكريم وجود دارد تمام مسلمانان يك قرآن را ميخوانند ميشنوند

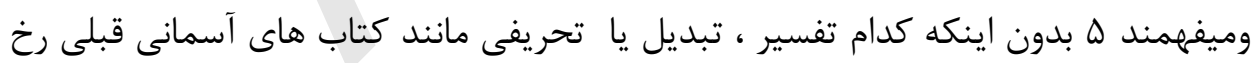




$$
\begin{aligned}
& \text { تحت عنوان قرانكريم مطالب ذيل را بطور مختصر به بررسى خواهيم كرفت: } \\
& \text { الف - مفهوم قرآن كريم : }
\end{aligned}
$$

قرانكريم داراى معناى لغوى واصطلاحى مى باشد كه اينك هركدام را به ترتيب توضيح

$$
\text { 1 - مفهوم لغوى قران كريمم }
$$

قرآن كريم درلغت مصدر مى باشد وبه معناى قرائت استعمال كرديده است . جنانجه

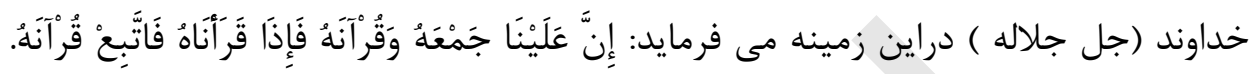

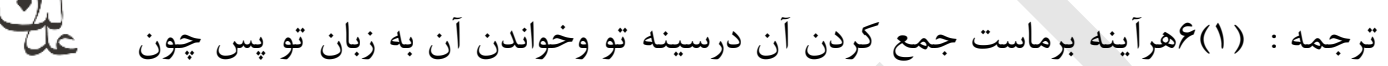

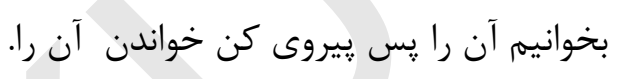

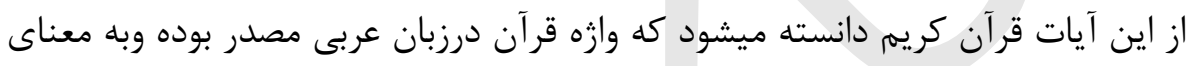

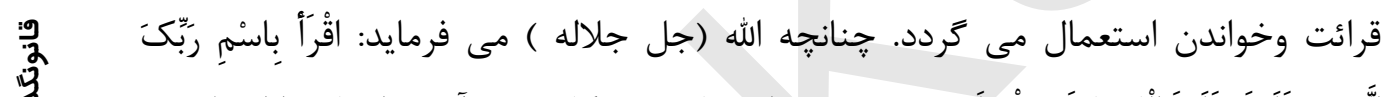

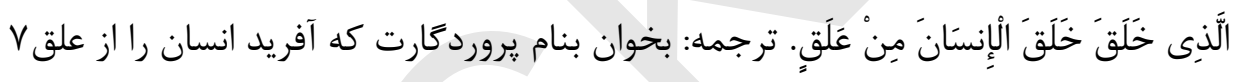

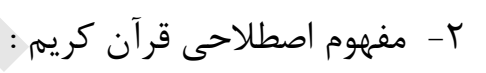

ازنقطه نظر علم اصول فقه قرآن عبارت است از سخنى كه از جانب خداوند (جل جلاله )

به حضرت محمد (صلى الله عليه وسلم ) به زبان عربى نازل گرديده ، با كوتاترين سوره خويش به تحدى ومقابله برخواسته ،درمصاحف به رشته تحرير درآمده بطور متواتر روايت شده ،تلاوت آن عبادت محسوب گرديده ، با سوره الفاتحه آغاز وبا سوره الناس اختتام يافته 


$$
\text { ب: طريقة بيان احكام درقرآن كريم · }
$$

احكام قرآن كريم به سه نوع تقسيم كرديده ( احكام اعتقادى احكام اخلاقى واحكام

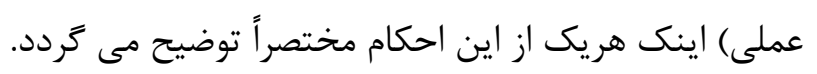

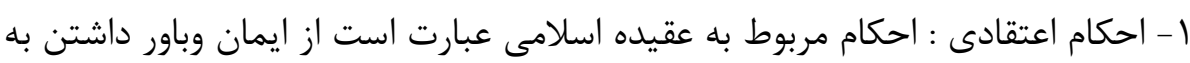

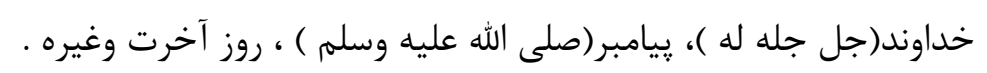

ז- احكام اخلاقى: احكام اخلاقى عبارت است از دستورات مربوط به تزكيه وتهذيب نفس.

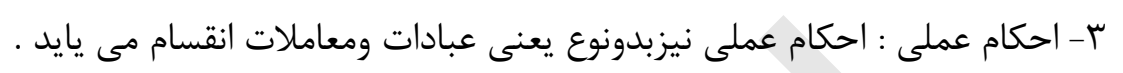

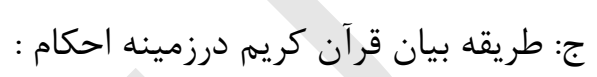

الف: احكام عبادى : احكام عبادى عبارت است از آن عده دستوراتى كه روابط انسان را با دان

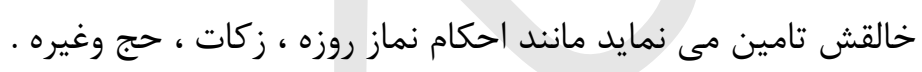

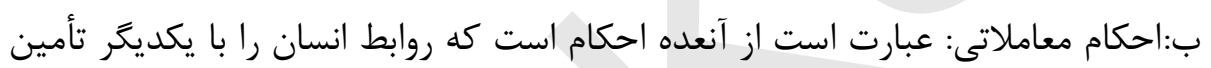

$$
\text { بيان قرآن كريم درعرصه احكام به سه نوع مى باشد: }
$$

الف بيان كلى : يعنى قرآن كريم احياناً قواعد ومبادى عمومى را كه اساس و و تهديداب

$$
\text { استنباط احكام شرعى محسوب مى شود بيان مى نمايد بطور مثال : }
$$

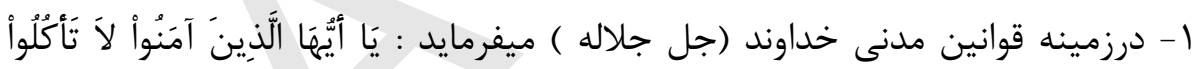

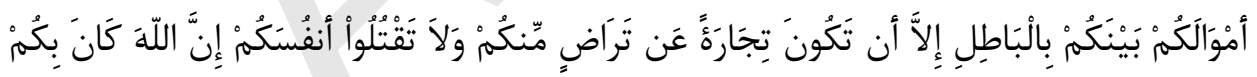

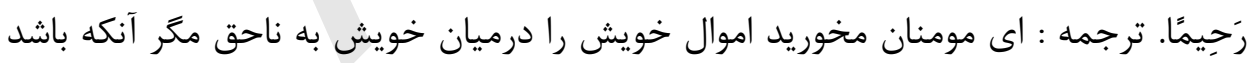

$$
\text { تجارت به خوشنودى يكديكراز شمان. }
$$

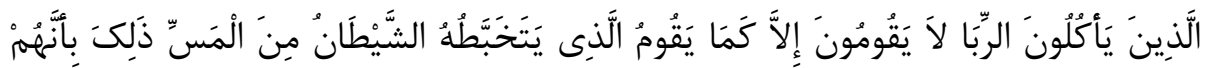

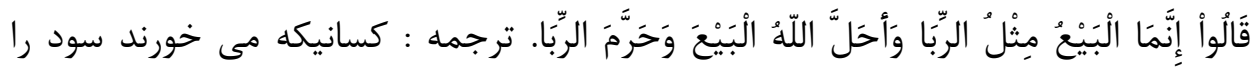

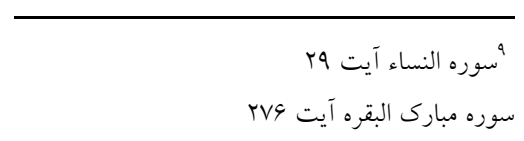


برنمى خيزند د ر روز قيامت مكر بر مى خيزندمانند كسيكه خراب ساخته حواس او را

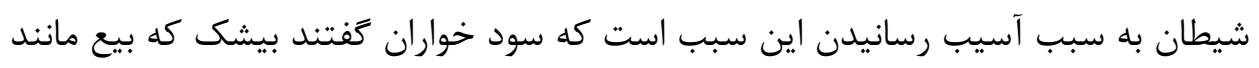

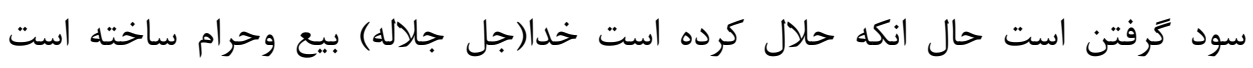

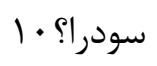

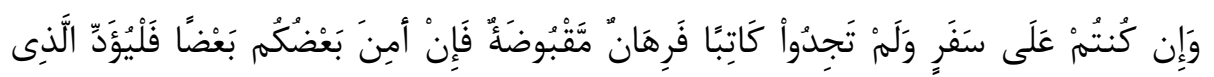

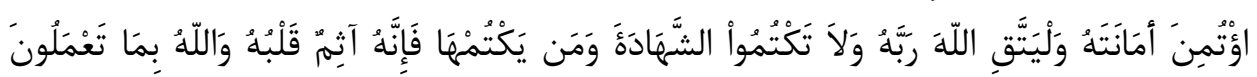

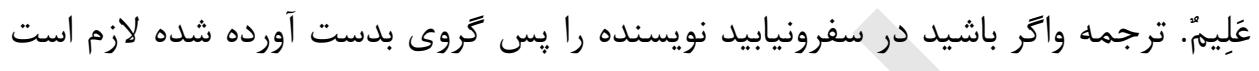

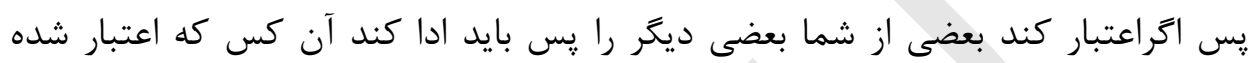

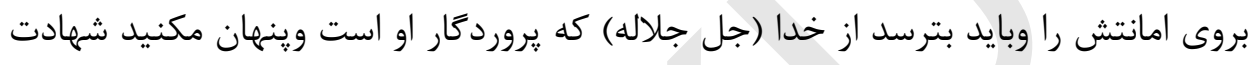

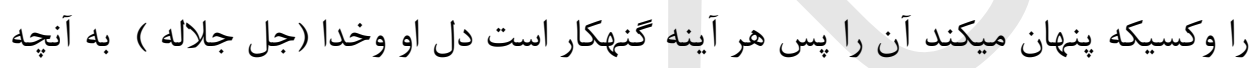

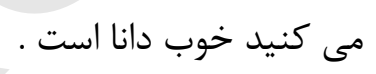

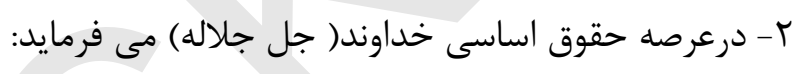

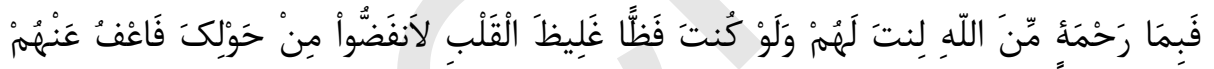

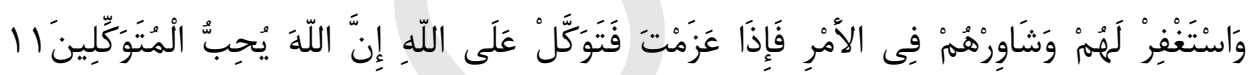

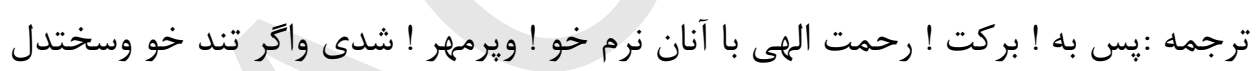

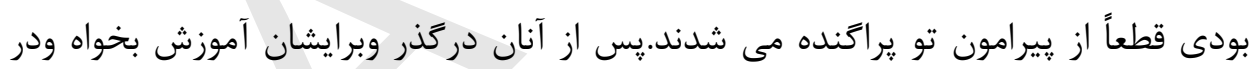

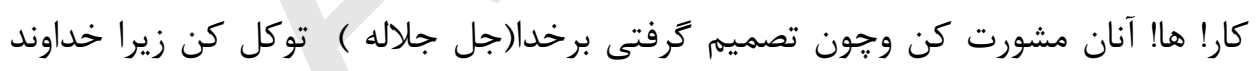

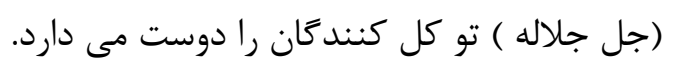

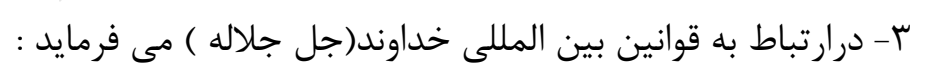




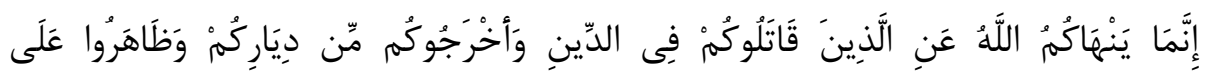

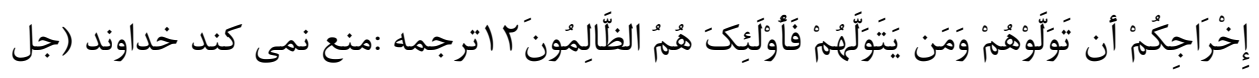

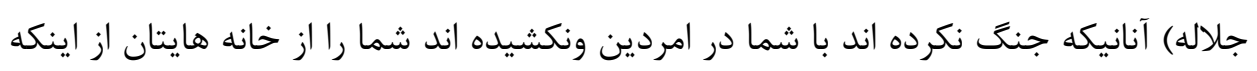

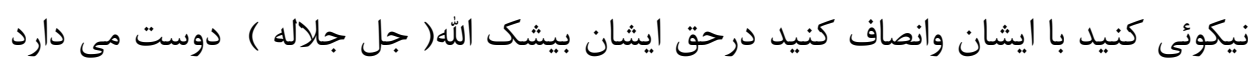

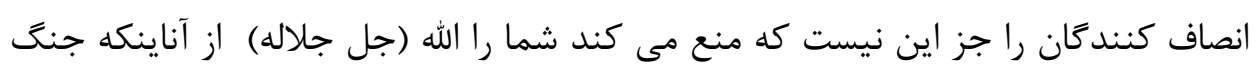

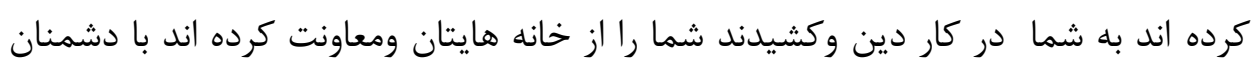

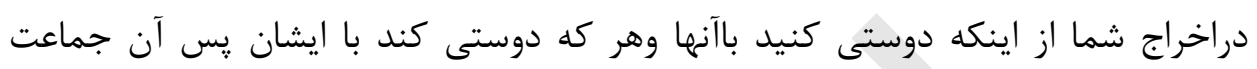

ستمعاران اند.

$$
\text { دوم : سنت نبوى (صلى الله عليه وسلم ) }
$$

سنت نبوى (صلى الله عليه وسلم ) دومين منبع قانونخذارى درنظام حقوقى اسلام سنت

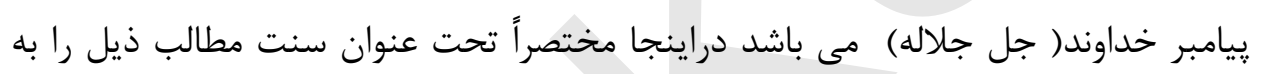

$$
\text { مفرسى مى كريم. }
$$

نزد فقها و علما اصول فقه سنت داراى يك معنى لغوى است ويكى هم اصطلاهى است كه ذيلاً بيان مى كردد: 1 - مفهوم لغوى سنت : سنت درلغت عبارت است از سيرت طريقه راه وردئ وروش ، برابر است

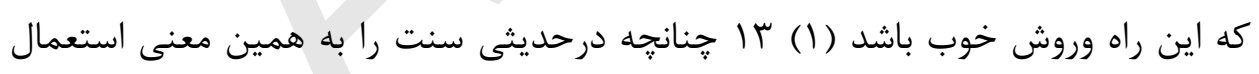

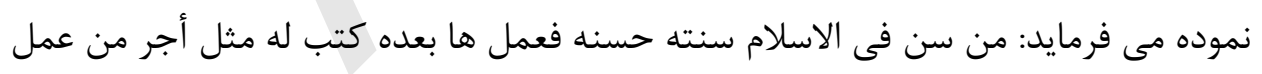

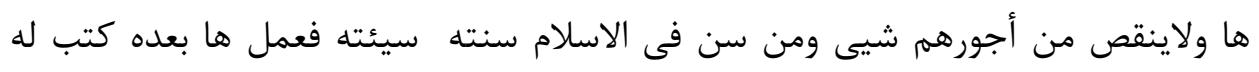

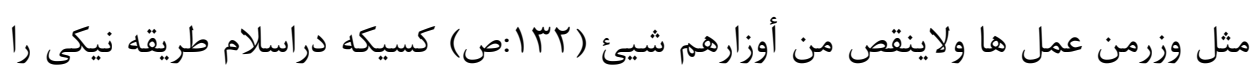

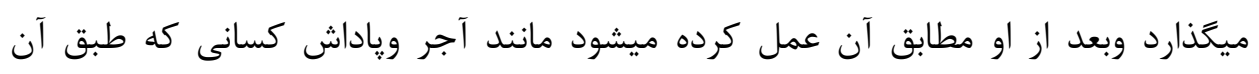

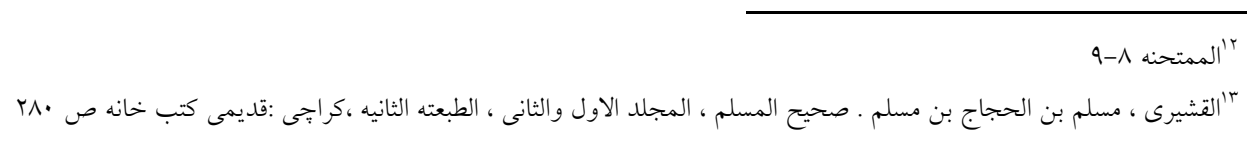


طريقه عمل ميكند براى او نوشته ميشود در حاليكه از اجر وياداش آنها نيز كاسته نمى شود وكسيكه دراسلام طريقه بدى را ميكذارد وبعد از او مطابق آن عمل كرده ميشود مانند كناه ومعصيت كسانى كه طبق آن طريقه عمل ميكنند براى او نوشته ميشد درحاليكه از كناه

$$
\text { ومعصيت آنها نيز كاسته نمى شود. }
$$

r- سنت دراصطلاح علماى اصول فقه: سنت عبارت از اقوال ، افعال وتقريرات حضرت محمد (صلى الله عليه وسلم ) بنا بر قول بعضى ها سنت عبارت از عبادت هاى نفلى است كه

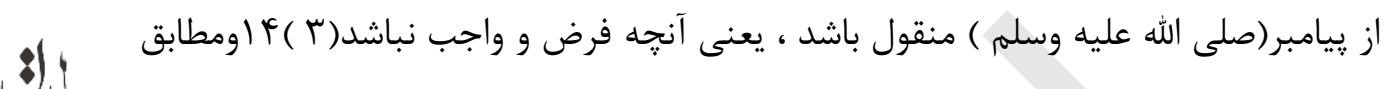

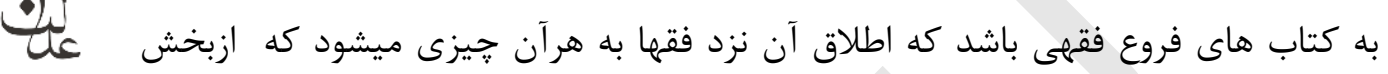

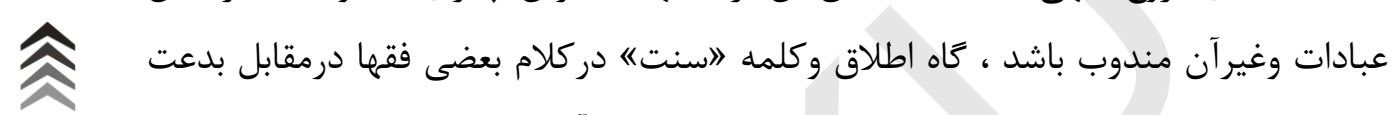

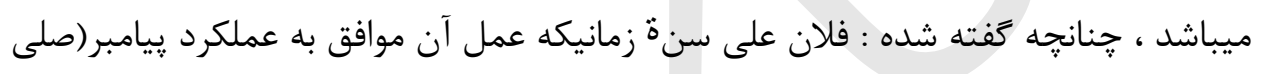

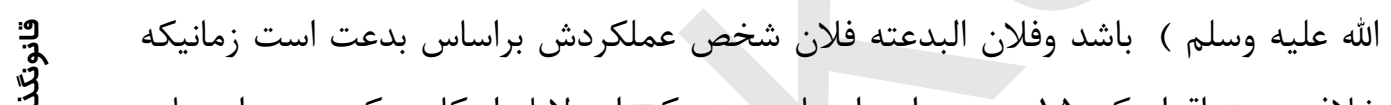
خلاف سنت اقدام كندها يُ به اين اعتبار سنت يكى از دلايل احكام ويك مصدر ازمصادر

$$
\text { تشريع وقانونخذارى است.ع } 19
$$

درارتباط به حجت بودن سنت نبوى در استنباط احكام شرعى علماء به دلايل ذيل ل

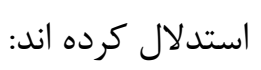

الف-قرآن كريمم : قرآن با اساليب مختلف براين امر تأكيد مى كند كه سنت نبوى يك از آندان منابع تشريع وقانونگذارى درنظام حقوقى اسلام است واز آن جمله آيات ذيل مى باشد: 


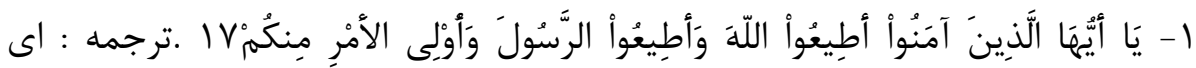

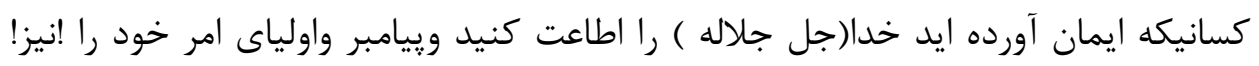

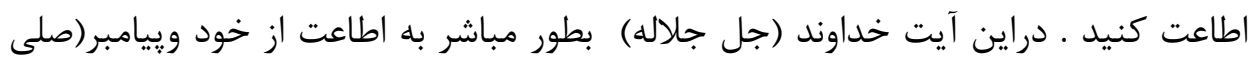

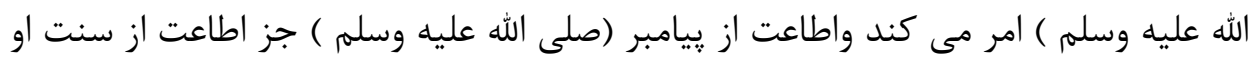

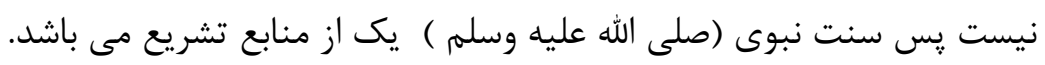

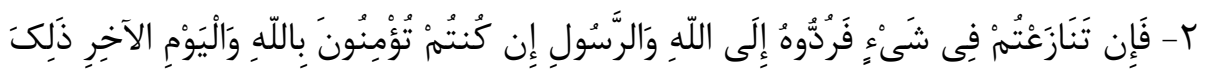

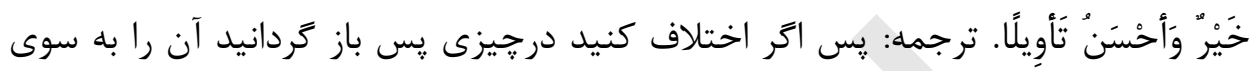

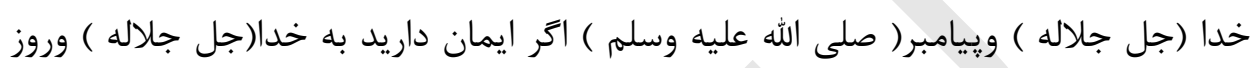

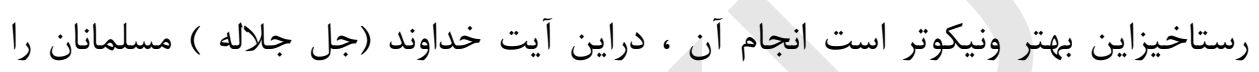

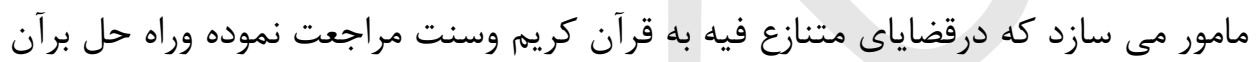

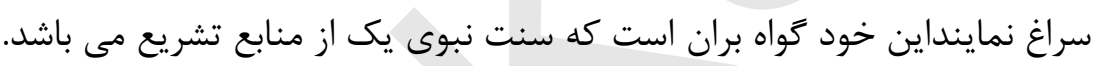

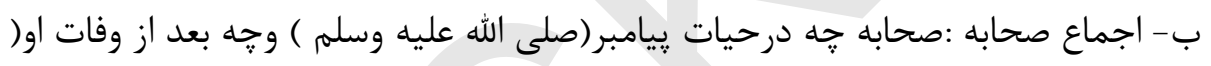

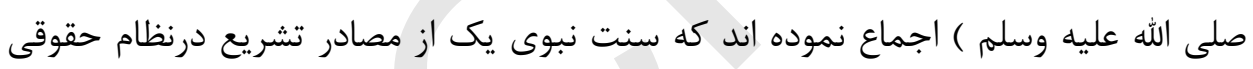

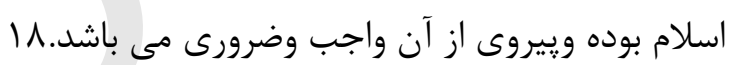
ج- عقل : ازطريق دليل قاطع ثابت شده است كه حضرت محمد (صلى الله عليه وسلم )

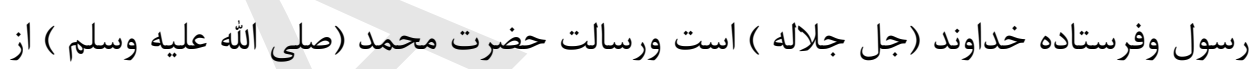

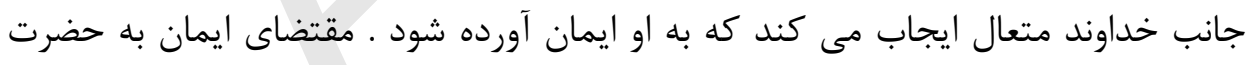

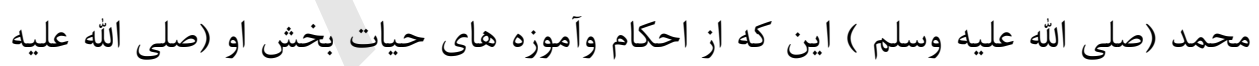

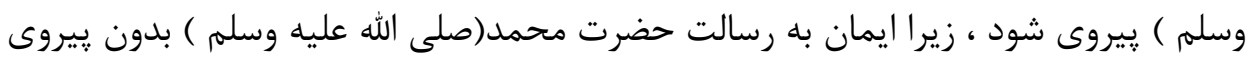

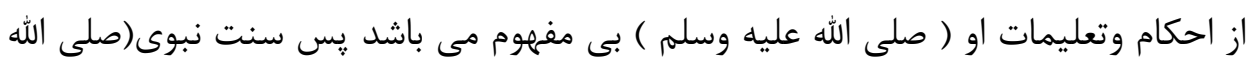

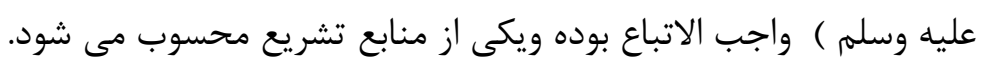




\section{جايگًاه سنت درقانونگذارى}

الف: جايغاه سنت درمقايسه با قرآن از ناحيه استدلال به آن : حديث بيامبر (صلى الله

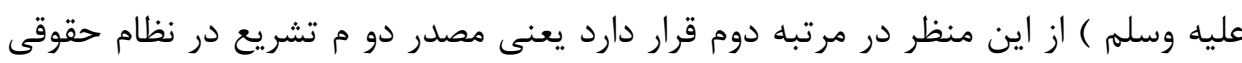

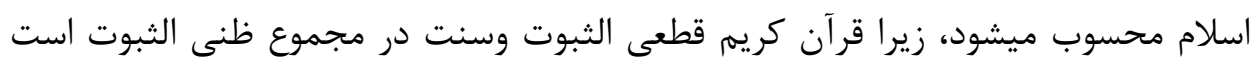
وقطعى الثبوت بر ظنى الثبوت مقدم مى باشد.

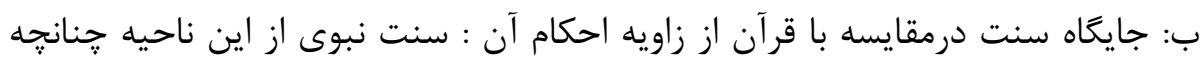

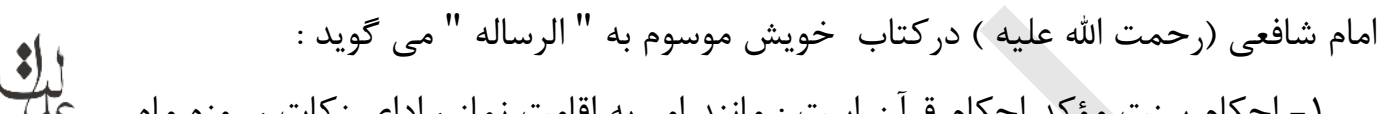

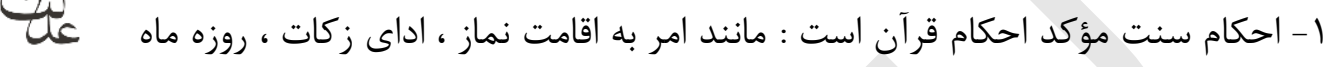

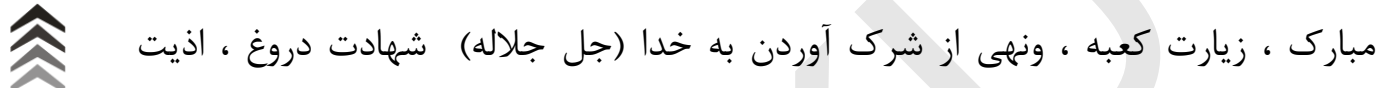
والدين ، قتل نفس به ناحق وخوردن مال مردم .

r- احكام سنت مبين احكام قرآن است : وبيان احكام قرآن توسط سنت نبوى(صلى الله عليه وسلهم ) به سه طريقه قرارزيرين مى باشد.

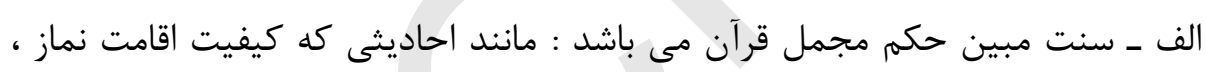
اداى زكات ، حج كعبه ،بيع صحيح ، بيع فاسد انواع ربا را بيان نموده اند.

ب ـ سنت مخصص حكم عام قرآن است : مانند قول ييامبر (صلى الله عليه وسلم ) ترجمه حديث : نه زن با عمه اش به نكاح گرفته مى شود ونه عمه با برادر زاده اش ونه زن

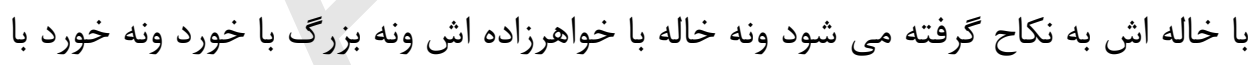
بزررگ به نكاح گرفته ميشود • r ـ اين حديث مخصص اين حكم عام قرآن است كه خداوند

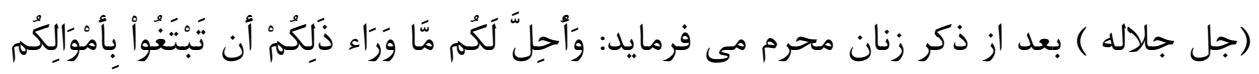

19

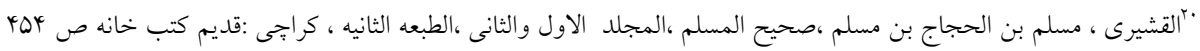


مُّحْصِنِينَ غَيْرَ مُسَافِحِينَ.ا ب ترجمه : وغير از اين! زنان نامبرده ! به وسيله اموال خود طلب كند در صورتى كه ياكدامن باشد وزناكار نباشيد ج: سنت مقيد حكم مطلق قرآن مى باشد:مانند اينكه پِيامبر (صلى الله عليه وسلم ) موضع قطع دست سارق را معين كرده است وآن عبارت است از بند دست در حقيقت اين

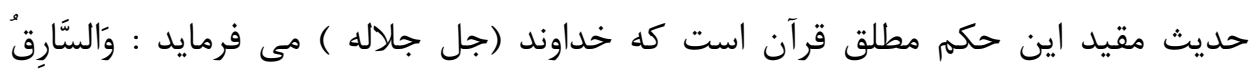

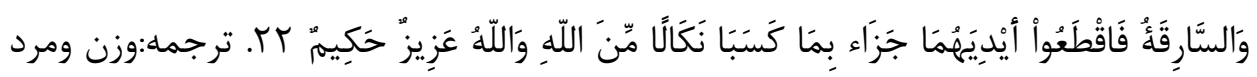
دزد را به سزاى آنجه كرده اند دستشان را به عنوان كيفرى از جانب خدا (جل جلاله ) ببريد وخداوند(جل جلاله ) توانا وحكم است. بـ- اجماع : سومين مصدر تشريع درنظام حقوقى اسلام اجماع مى باشد وماتحت عند عنوان

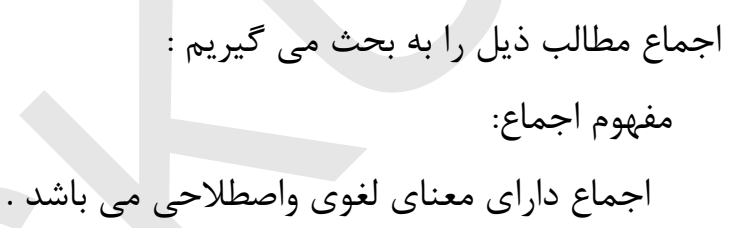

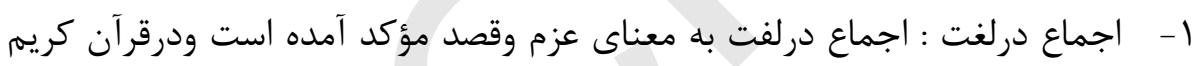
درجندين مورد وازه اجماع درهمين مورد استعمال شده است. جنانجه خداوند ((جل جلاله

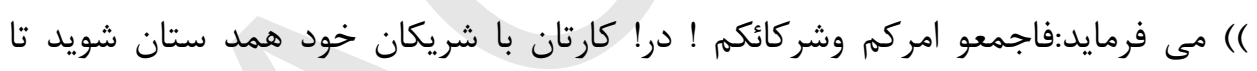
كارتان ملتبس ننمايد سيس درباره من تصميم بكريد ومهملتم ندهيد. r- اجماع دراصطلاع : اجماع از نظر علماى متعددى تعريف شده كه دراين جا به نظر ابن السبكى اكتفاء مى كنيم : كه كفته است " هو اتفاق مجتهد الامته بعد وفات سيدنا

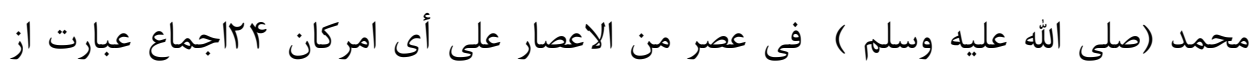

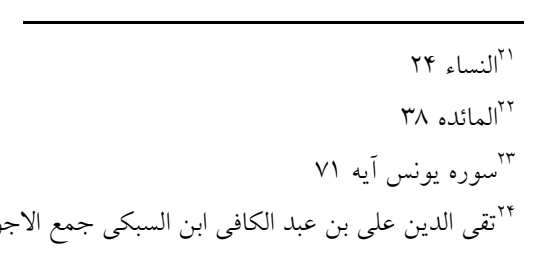


اتفاق همه مجتهدين امت محمد صلى الله عليه وسلم بعد از وفات او در تمام عصر ها

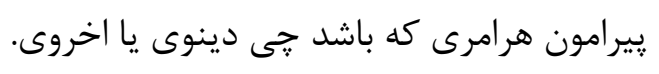

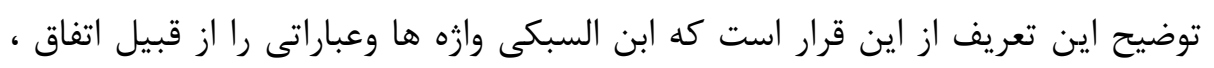

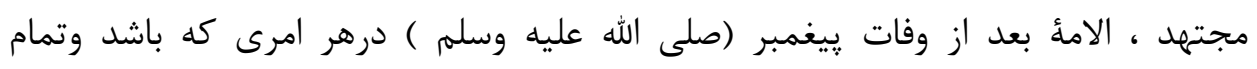

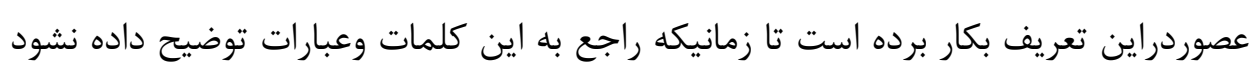
مفهوم تعريف بطوردرست وهمه جانبه درك نخواهد شد.

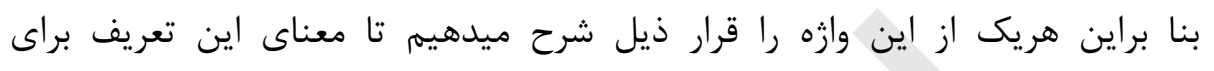

ا - كلمه " اتفاق " دراين تعريف به مثابه جنس بوده كه تمام اتفاقات را دربرميكيرد

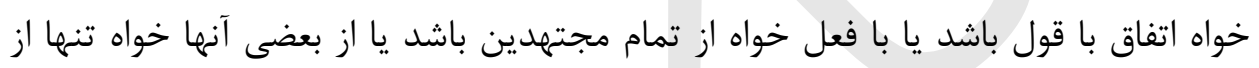

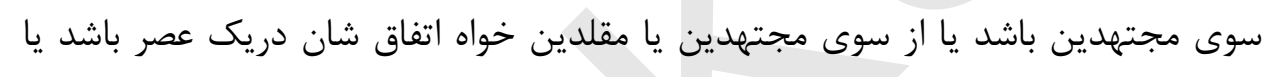
درعصور مختلفه . r- كلمه "مجتهد"بمثابه فعل است كه اتفاق غير مجتهدين از اين تعريف خارج ميشود.

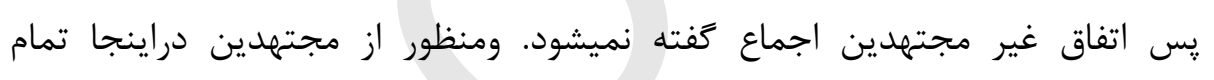

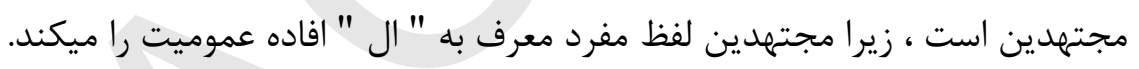
بـ "ال" در كلمه المئ الف ولام عهد علمى است ومنظور از آن آن امت محمد (صلى الله عليه

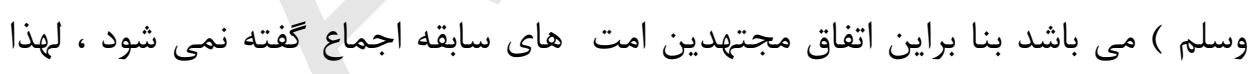

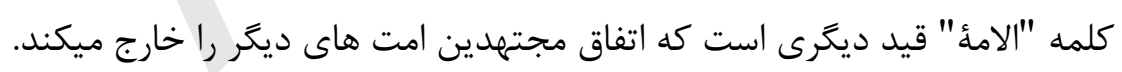

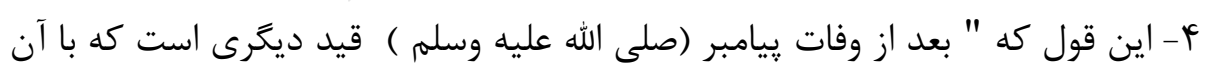

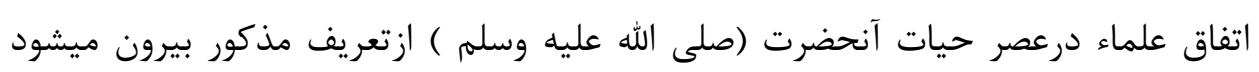
وآن را اجماع نمى نامند. ه- اين قول " درهر امرى كه باشد " شامل تمام امور از قبيل امور دينى ،دنيوى ،عقلى

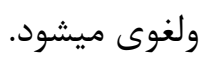


צ- اين قول " درهمه عصرها " تمام زمانه ها را دربر ميخيرد خواه عصر صحابه باشد يا

$$
\text { عصر هاى ديخر. r. }
$$

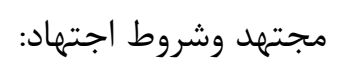

درتعريف اجماع كفته شد كه اجماع عبارت است از اتفاق مجتهدين - قبل از اينكه راجع

به حجت بودن اجماع وانواع آن توضيحاتى داشته باشيم مناسب مى بينهم كه بيرامون مجتهد

$$
\text { وشروط اجتهاد معلوماتى ارائه كنيم. }
$$

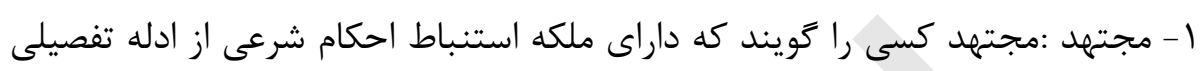

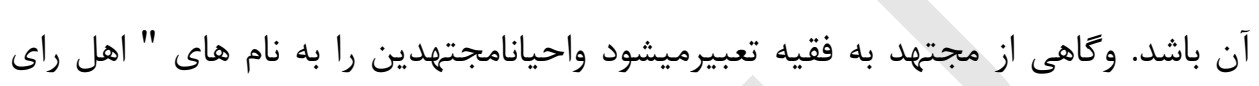
واجتهاد " ويا "اهل حل عقد " يا د مى كند آنجه كه از اين تعريف بر مى آيد آين اين است كسيكه توانايى استنباط احكام شرعى را از مصادر آن ندارد مجتهد به معناى مذكور كفته

$$
\text { نمى شود. }
$$

r- شروط اجتهاد " شخصى مجتهد كفته ميشود وداراى ملكه استنباط مى باشند كه

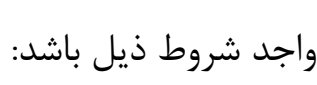

$$
\text { شناخت كامل بيرامون قرآن كريم. }
$$$$
\text { شناخت كامل پيرامون سنت نبوى . }
$$

شناخت كامل راجع به قضايايى كه تا اكنون مورد اجماع قرار كرفته است.

$$
\text { شناخت كامل درمورد علم اصول فقه . }
$$

شناخت كامل علوم لغت از قبيل صرف، نحو ، بلاغت وفقه اللغه .

$$
\text { r- دليل حجت بودن اجماع : }
$$


زمانيكه اجماع با درنظرداشت شروط آن منعقد گرديد دليل قطعى ملزم برحكم مسأ له

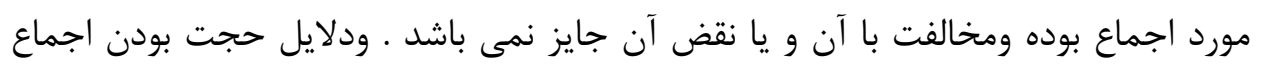
عبارتند از:

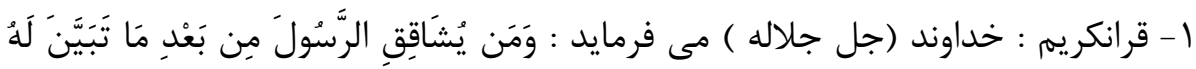

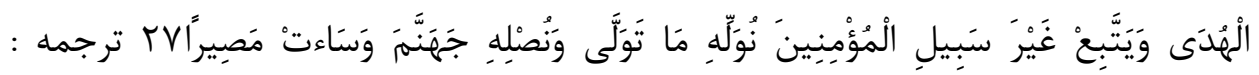

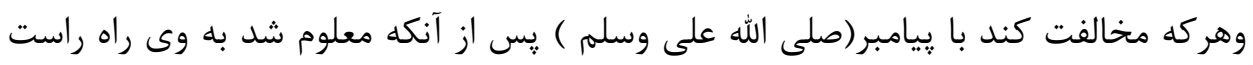

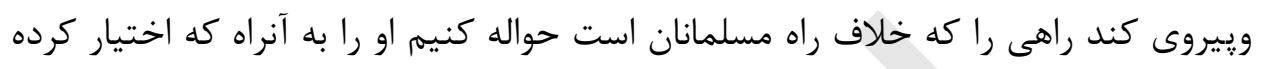
ودر اريم او را به دوزخ وبد مرجع است ـ دراين آيت خداوند (جل جلاله ) مى فرمايد كه راه

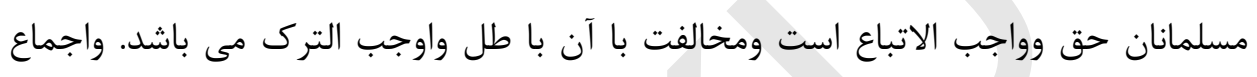
مسلمانان بريك حكم شرعى درحقيقت راه مسلمانان وحق بوده وِيروى از آن واجب وضرورى مى باشد. r- سنت نبوى : يِامبر(صلى الله عليه وسلم ) مى فرمايد : ان أمتى لا تجتمع الى بلى

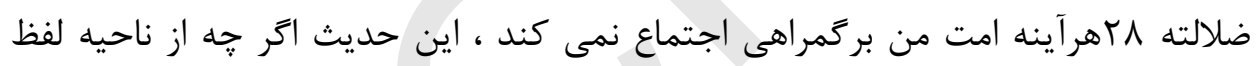
متواتر نيست ولى از ناحيه معنى ومفهوم متواتر است، بنا براين قطعاً افاده آن را مى كند كه

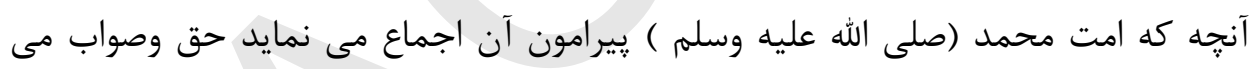

ب- عقل: اجماع واتفاق مجتهدين بريك مساله بايد بر اسا س يك دليل شرعى باشد زيرا اجتهاد واستنباط احكام طبق هوى ونفس نيست ، بلكه مطابق قواعد وضوابط معين وطرق وميتودهاى ويزه صورت ميكيرد ـ بنا براين هنحاميكه مجتهدين بريك حكم شرعى اتفاق مى لى كنند ما اين امر ادراك مى نمايم كه آنها يك دليل شرعى دارند كه يقين هيناً اساس رأى ونظر مورد اتفاق آنها را تشكيل ميدهد ، زيرا در غير آن صورت اتفاق آنها دور از امكان به نظر مى مي 
رسد براى آنكه عقول وقرايح انسان ها متفاوت مى باشد وبدلايل فوق براين امر دلالت ميكند كه اجماع يكى از منابع تشريع درنظام حقوقى اسلام است وِيروى از آن لازمى مى آنى

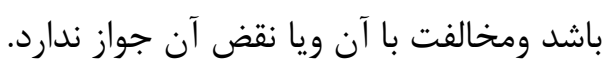
F - قياس : جهارمين مصدر تشريع درنظام حقوقى اسلام قياس مى باشد وداراى معانى لغوى واصطلاحى ذيل است. قياس درلغت به معنى اندازه كردن آمده است جنانجه كَفته شده كه قاس احمد الثوب با

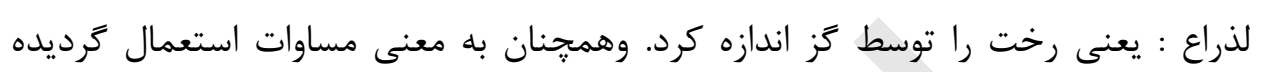
است طوريكه كفته ميتوان فلان" يقاس فلان " يعنى فلان شخص رحت با فلان مساوى است.

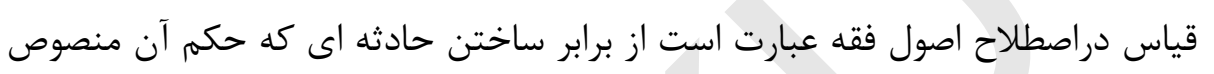
نيست با حادثه كه حكم آن منصوص است درحكم منصوص عليه بخاطر اشتراك آن دو

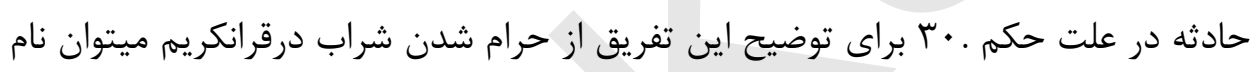
برد كه تمام مسكرات براساس قياس برخمرحرام است بدليل اشتراك همه دربى هوشى . اركان قياس

از تعريف فوق واضح مى شود كه قياس جهارركن دارد: اصل: كه آن را مقيس عليه مى گويند. فرع : كه آن را مقيس گويند ودر مورد حكم آن نص نيامده وقرار است حكم اصل با شيوه قياس براى آن داده شود. علت حكم كه آن عبارت است از وصف مشترك بين اصل وفرع كه بر اساس آن حكم اصل به فرع انتقال داده مى شود.

حكم اصل: كه آن عبارت است از حكم شرعى كه بِيرامون آن دراصل نص وجود دارد. 


$$
\text { دليل حجت بودن قياس }
$$

درارتباط به اينكه قياس يكى از منابع تشريع در نظام حقوقى اسلام مى باشد علماء

$$
\text { دلايل زيادى قرارذيل ارائه نموده اند : }
$$

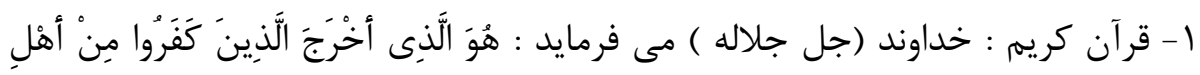

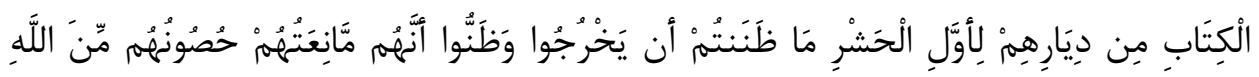

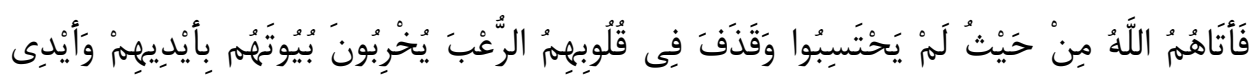

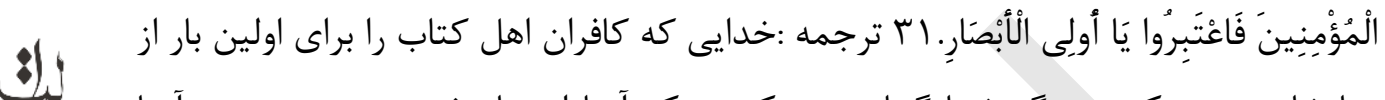

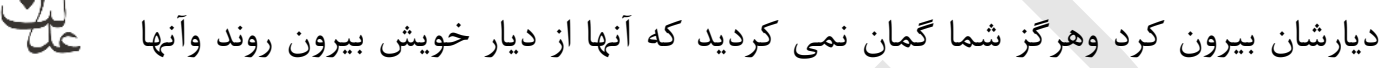

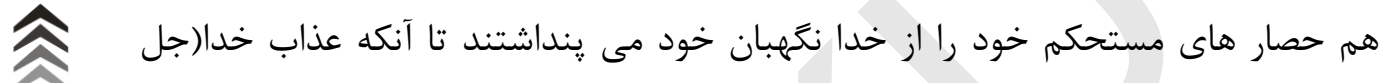

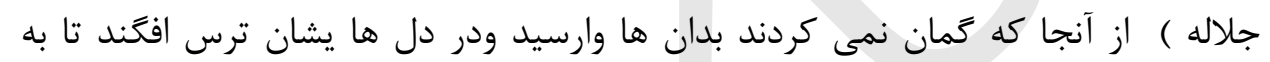

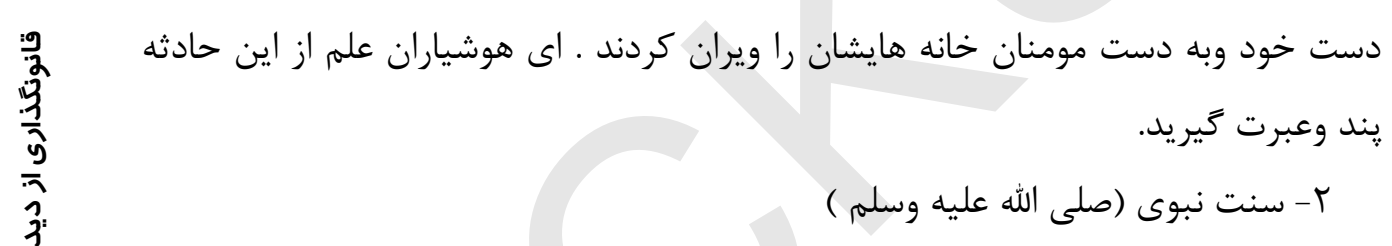
درحديث مشهور آمده است زمانيكه يِيامبر(صلى الله عليه وسلم ) حضرت معاذ (رضى الله

را منحيث قاضى به كشور يمن فرستاد از او يرسيد كه بواسطه جه جيز قضاوت وحكمم

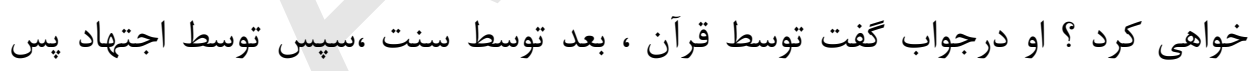

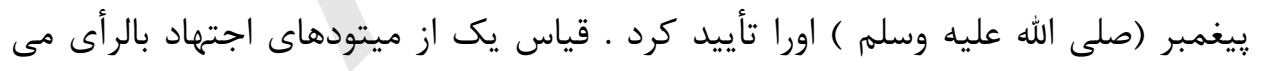
باشد بنا براين قياس مشروع بوده ويكى ازادله احكام مى باشد.

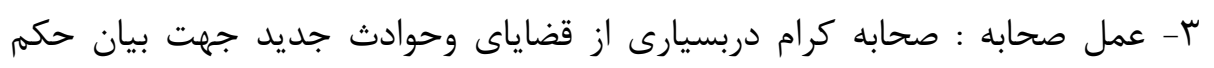
شرعى آنها از شيوه قياس استفاده ميكردند مانند مسأله عول كه درميراث آن را به حان حالت افلاس مديون قياس كردند. 
ץ- عقل : هدف از تشريع احكام تحقق بخشيدن به مصالح بندكان است وقياس يكى از

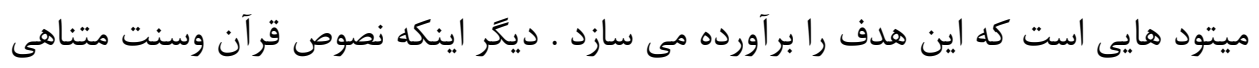

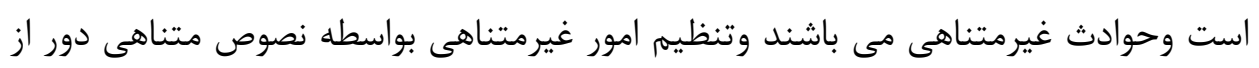

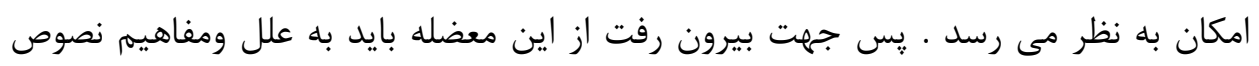

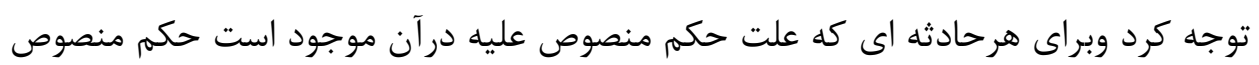

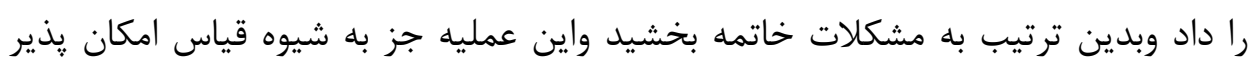

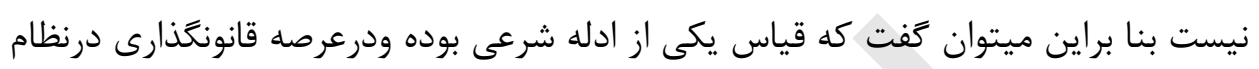
حقوقى اسلام نميتوان از آن استغناء حاصل نمود. 


\section{د افغانستان د قاضيانو لياره د لاربنود كثاب حخده زبارن}

III

$$
\begin{aligned}
& \text { دوهمه برخه }
\end{aligned}
$$

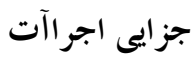

$$
\begin{aligned}
& \text { لومرى باب } \\
& \text { له جزايى محاكمي ثخه ترمخه اجرآت بات }
\end{aligned}
$$

$$
\text { لومزى خبرى: }
$$

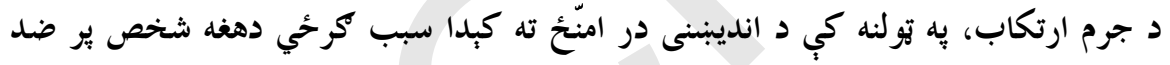

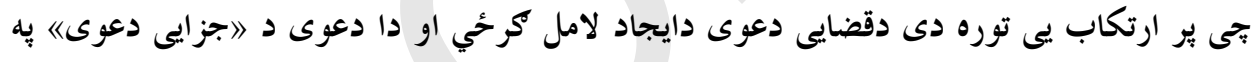

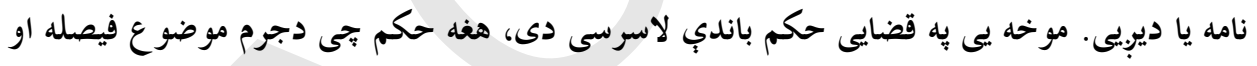

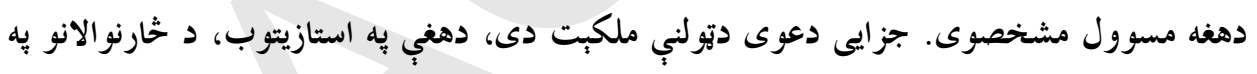

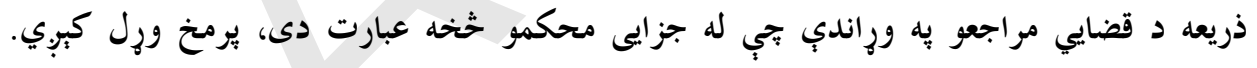

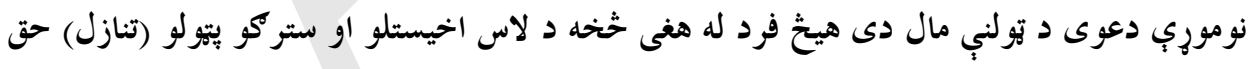

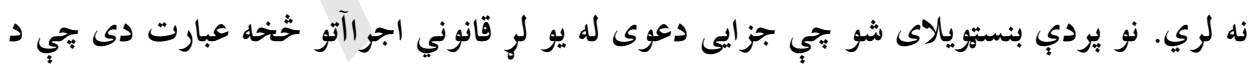

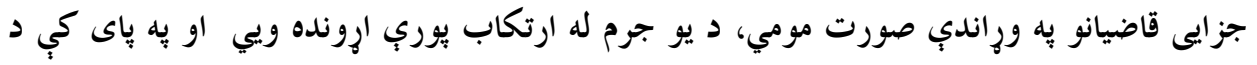

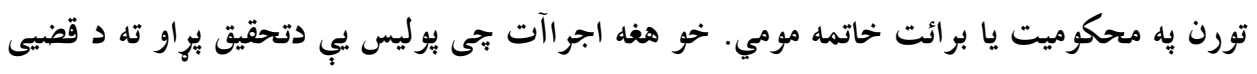

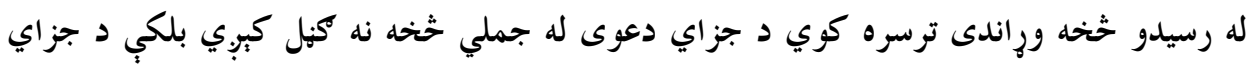
قضيى د اجرآتو له جملي خخخه بلل كوري.

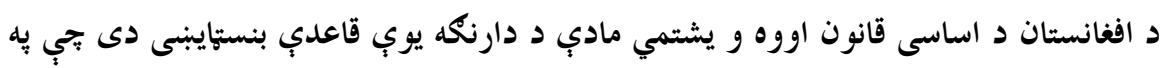

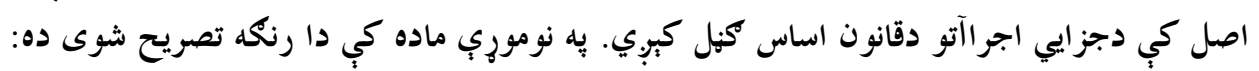


》هيخ يو عمل جرم نه كنبل كببري خو دهغه قانون له مخبي جب د جرم تر ارتكاب د مخهه نافذ شوى

هيخو كى دقانون له حكمونه برته تعقيبيداى، نيول كبداى او يا توقيفيداى نه شي.

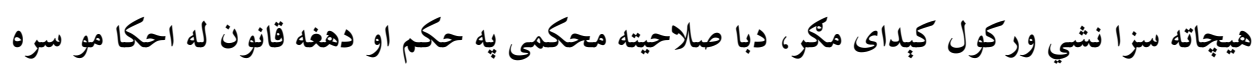

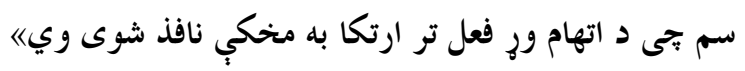

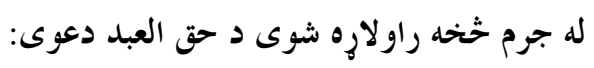

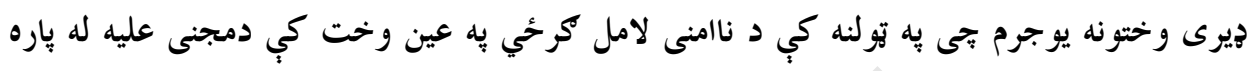

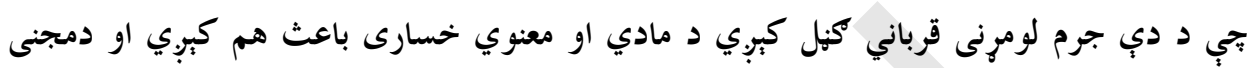

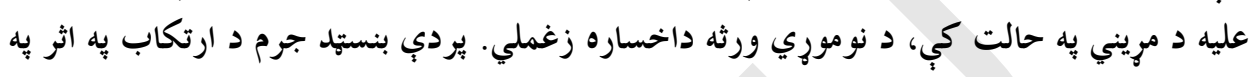

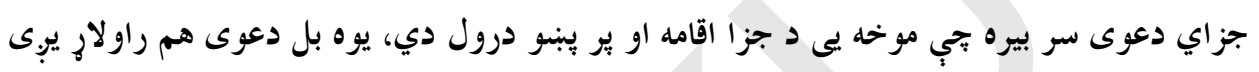

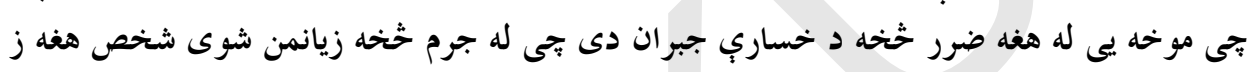

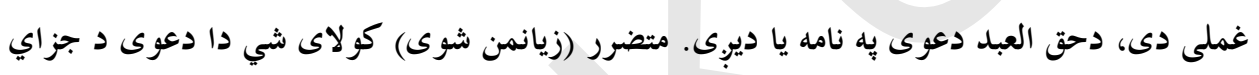

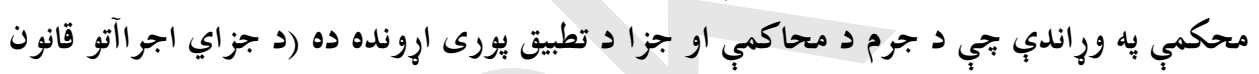

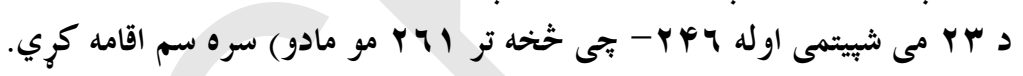

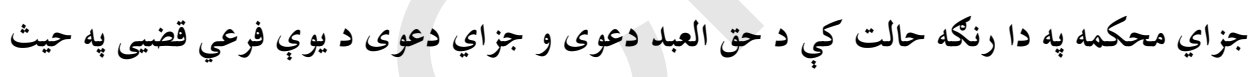

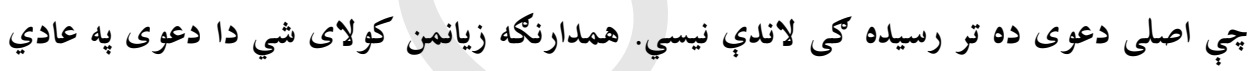

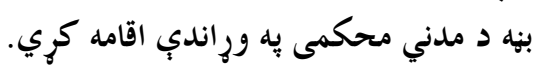
د جزاي دعوى او حق العبد دعوى ترمنح بيلتون:

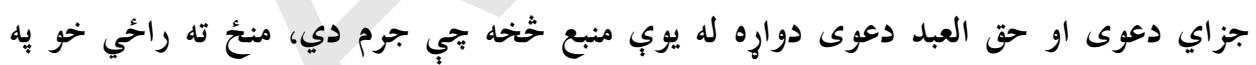

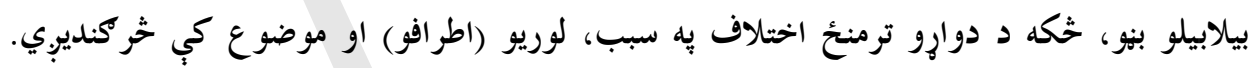

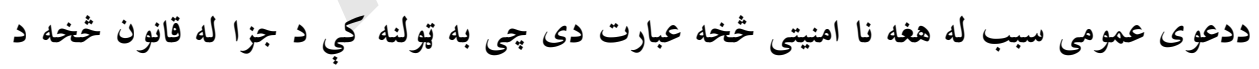

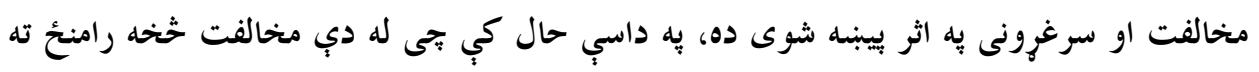

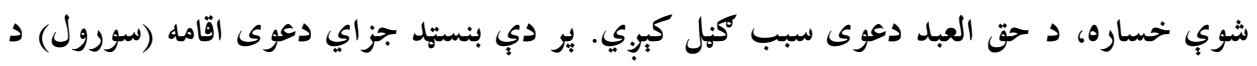

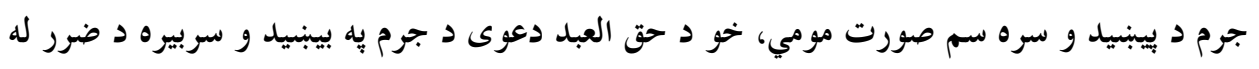

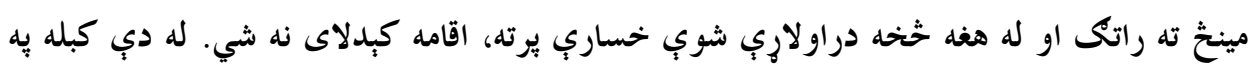

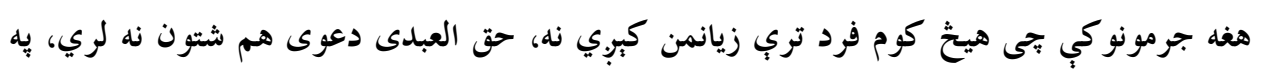


داسب حال كي تجي عمومي دعوى وجود لري، لكه سياسي جرمونه، د تابعيت د سلبيدو جرمونه او

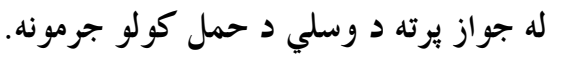

د تورن مفهوم:

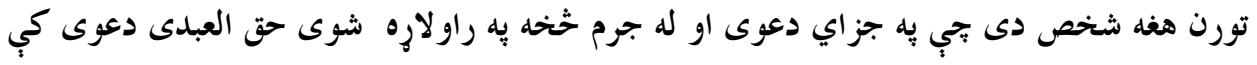

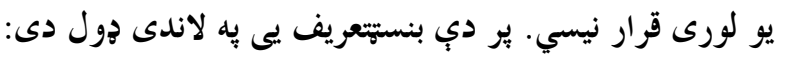

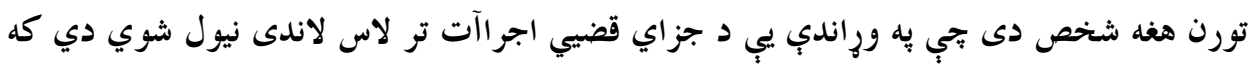

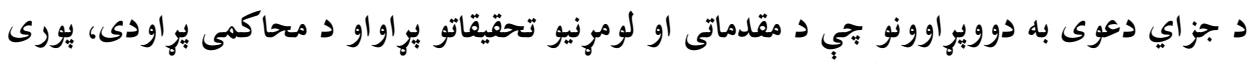

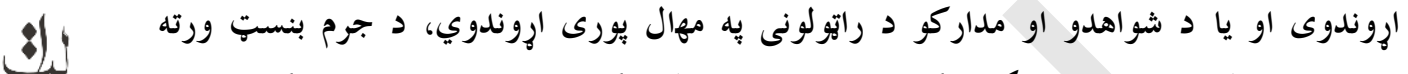

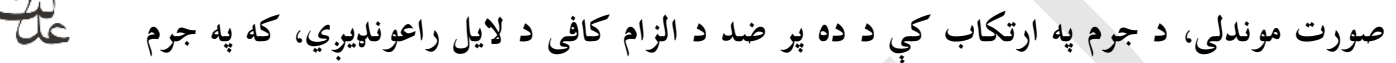

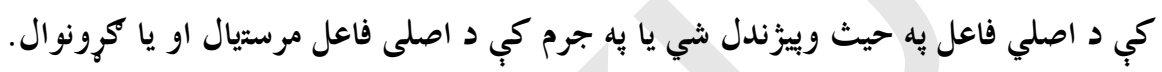

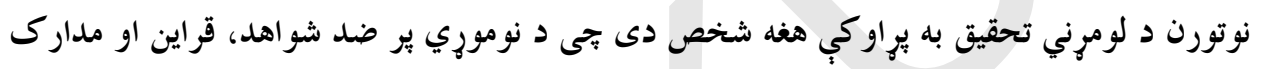

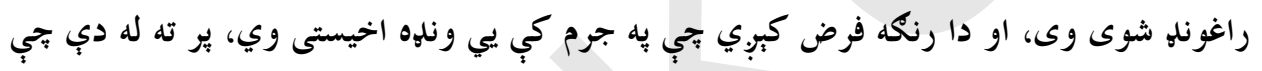

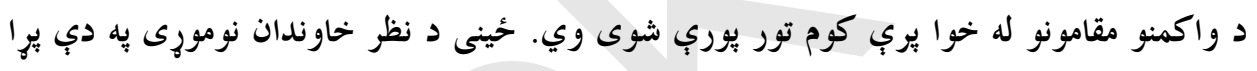

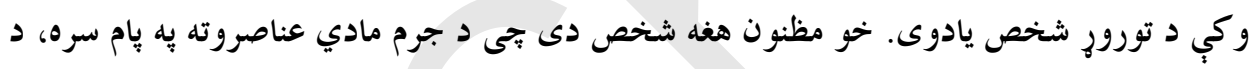

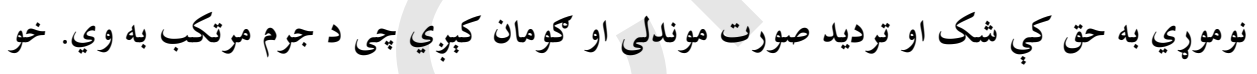

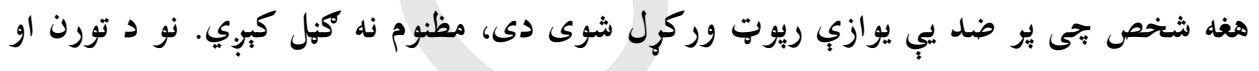

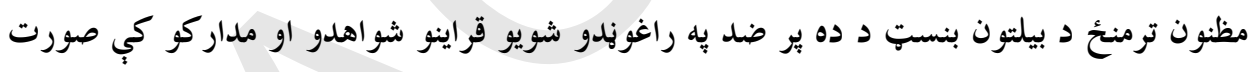

نو له دي امله هغه شخص تب د جرم د ارتكاب نسبت ورته نه دى وركرل شوى، تورن نه كنبل

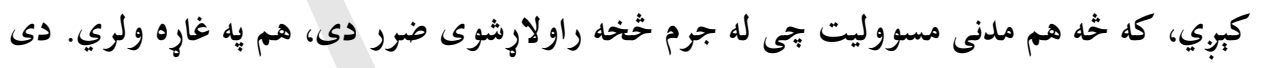

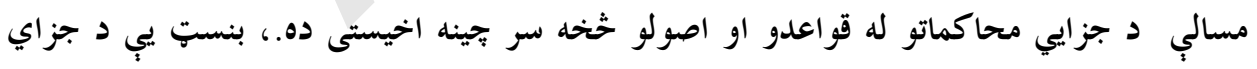

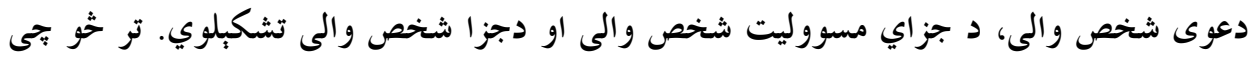

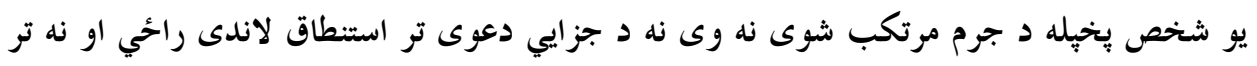

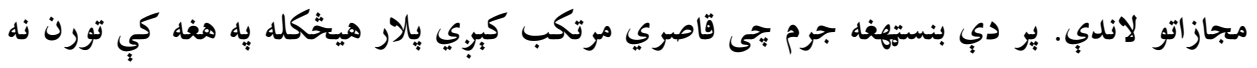

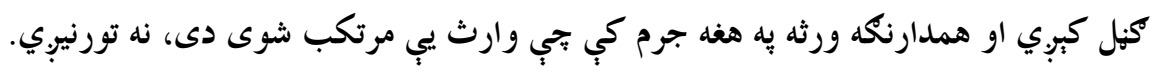

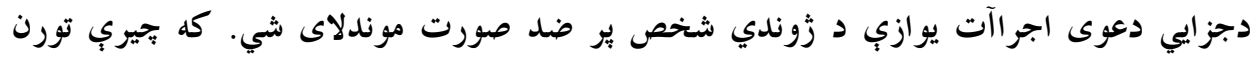

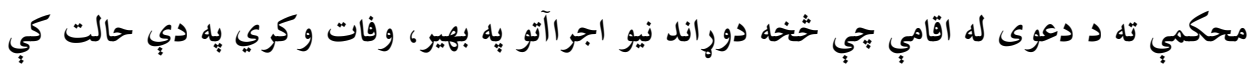


خارنوالي بايد د جزايي دعوى د نه اقامه كولو امر صادر كري، خكه دا دعوى د تورن بِ مرينه ساقطي.ري.

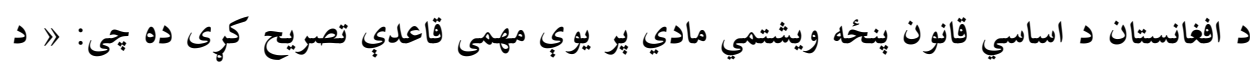

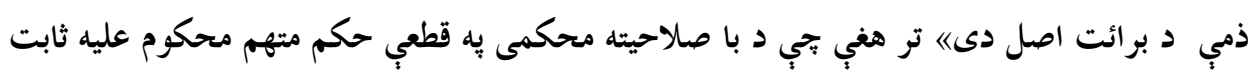
نه شي، بى كناه كنبل كبرب. د اساسي قانون شببرويشتمى مادي د جرم د شخصي والي به اروند داه دا رنكه تصريح كريده: \جرم يو

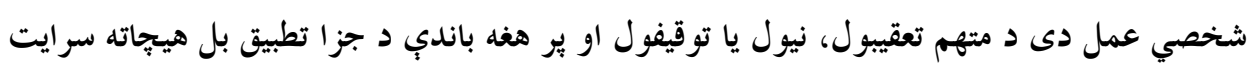

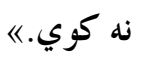

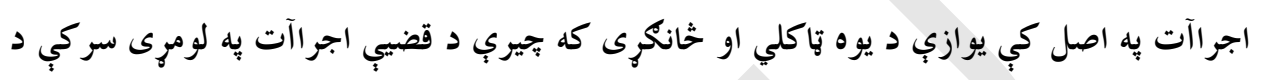

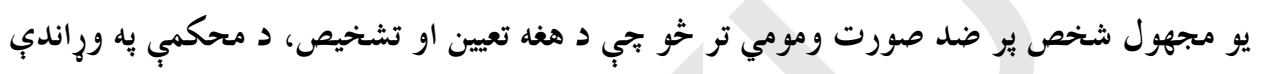

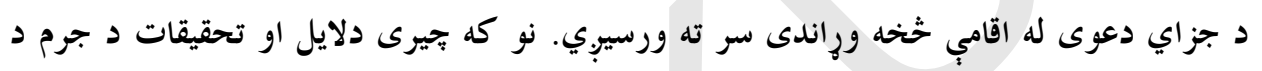

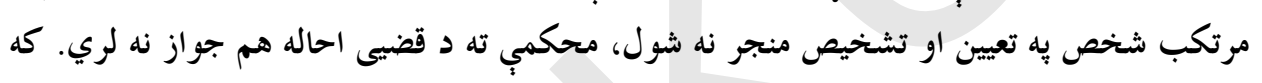

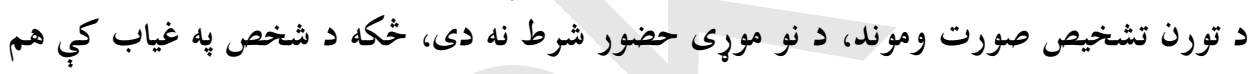

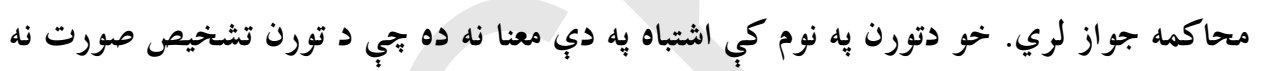

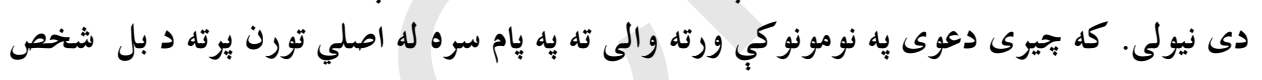

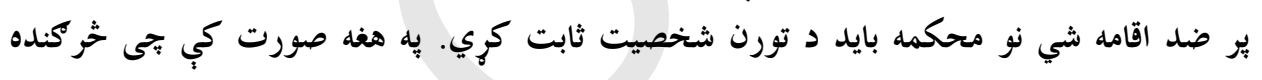

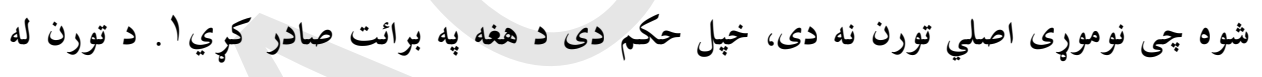

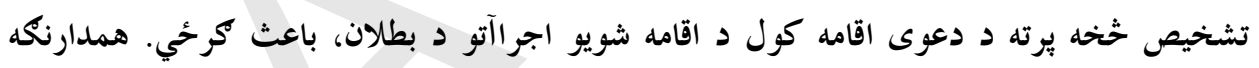

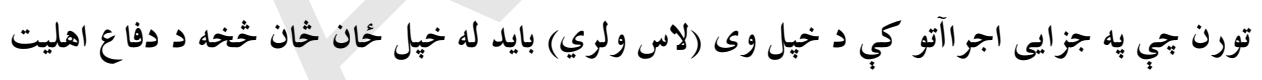

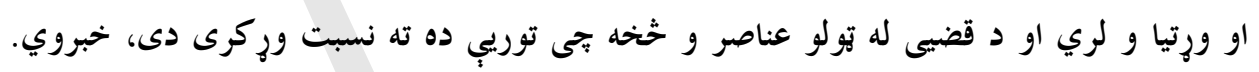

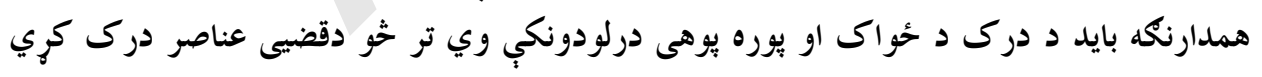
او وكولاى شي له خبل حان خخه دفاع وكري.

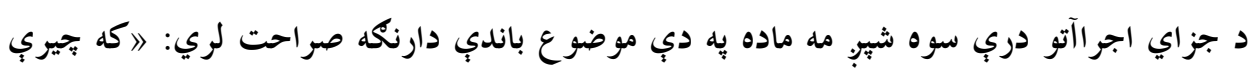

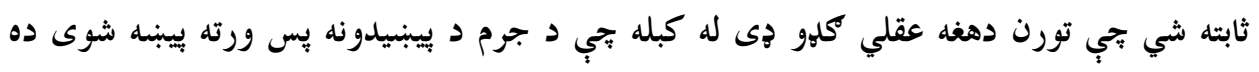

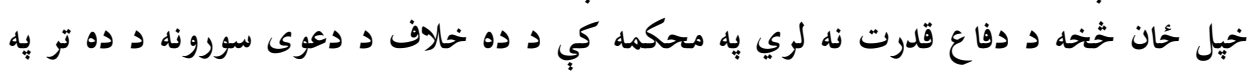
' - دكتور محمود سلامه: الاجراءات الجنائيه فى التشريع المصرى ج 1، 1999 / 1999 ص •هץ. 


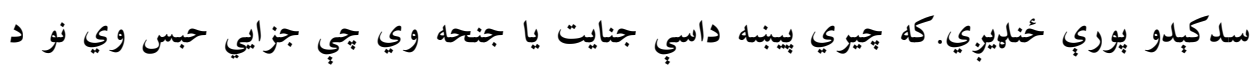

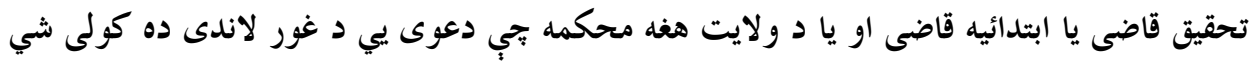

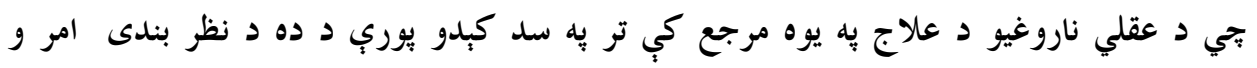

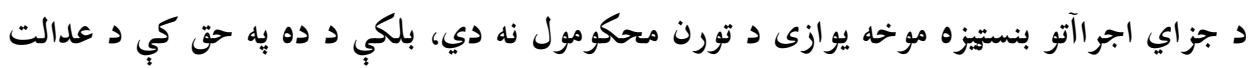

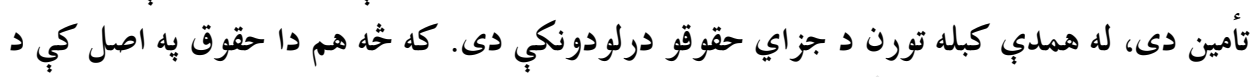

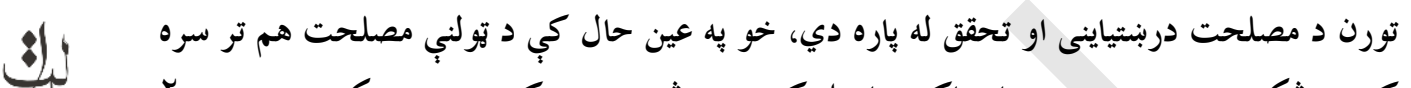

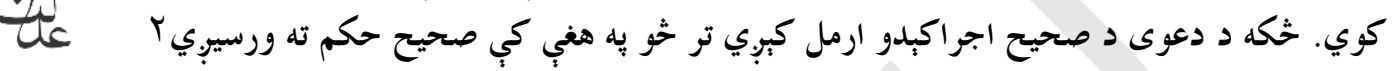

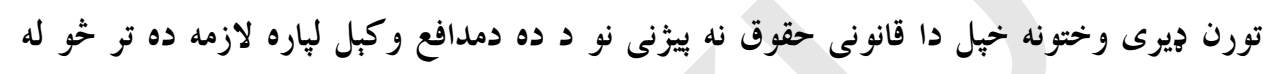

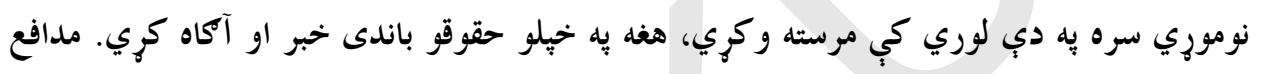

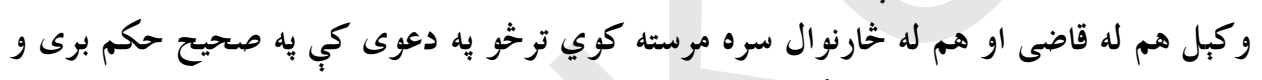

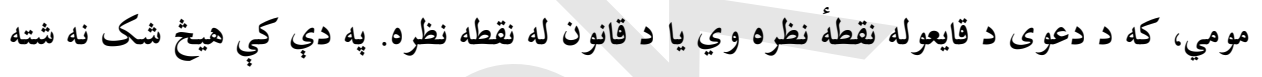

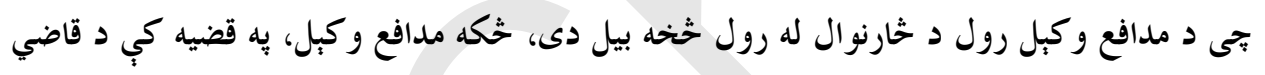

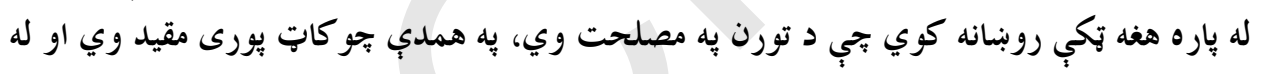

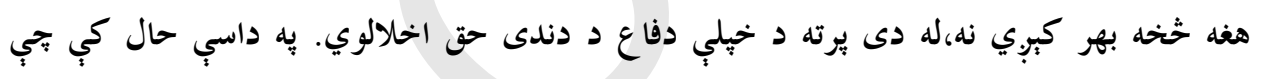

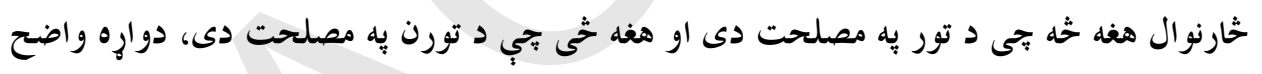

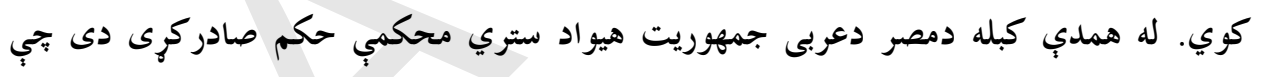

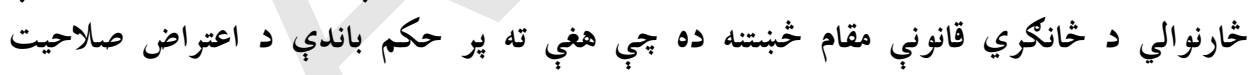

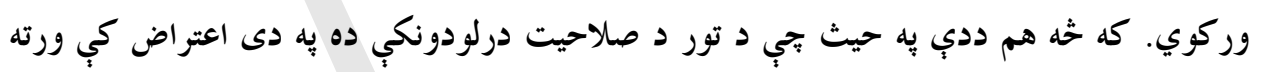

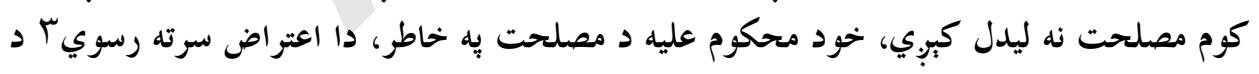

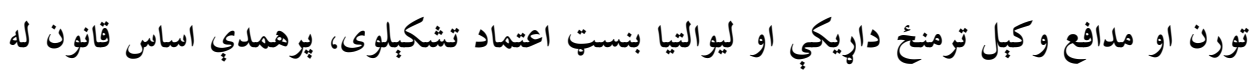

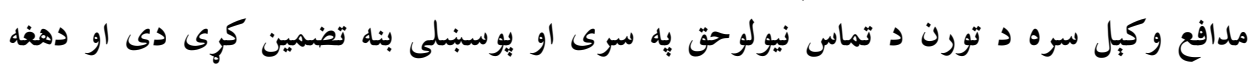

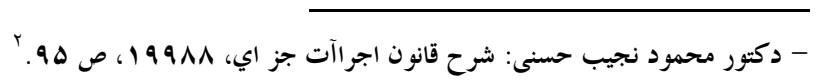

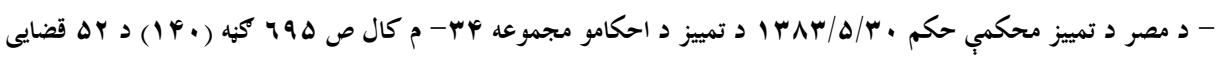

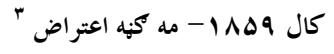


سندونو او مكتوبونو (ليكونو) ضبطولويب تبي د تورن او مدافع وكبل ترمنحُ رد او بدل (استول او واو

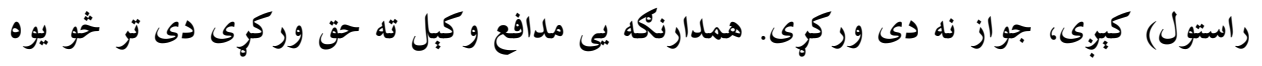

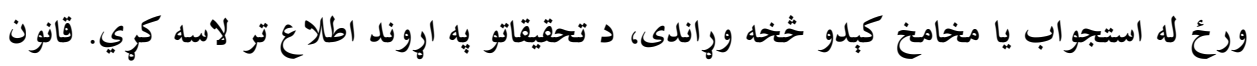

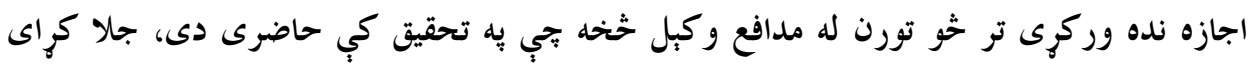

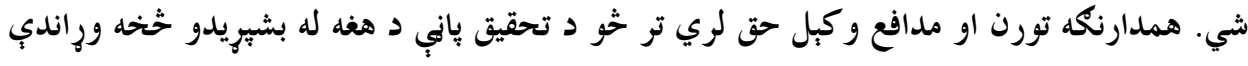

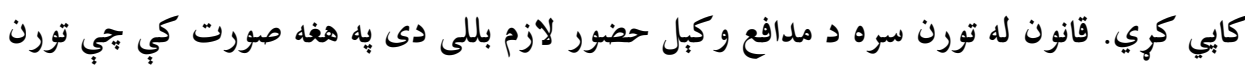

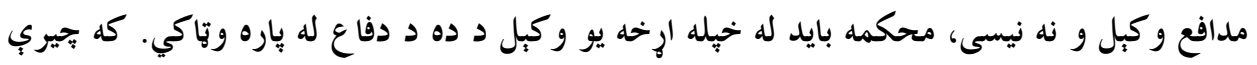

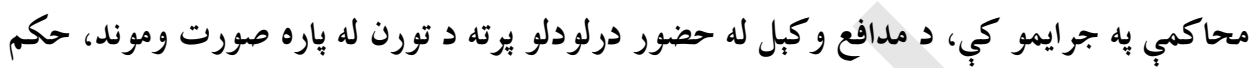

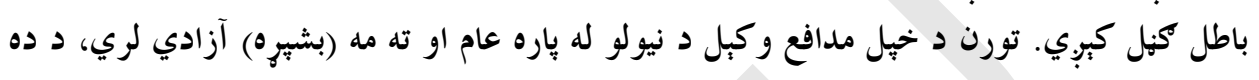

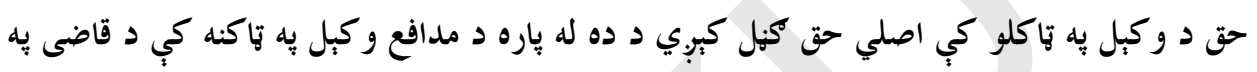

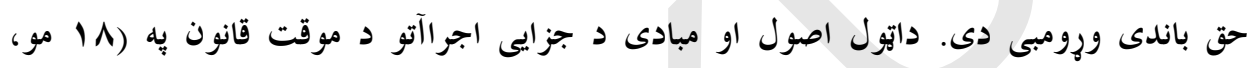

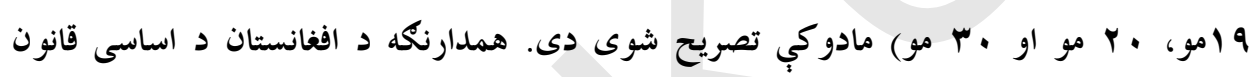

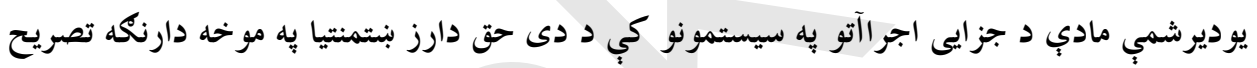
كريده: اهر خوى كولاى شي تبي له نيول كبدو سره سم له خحانه د اتهام دليرى كولو او يا دحق د ثابتولو لِاره مدافع وكبل وتّاكي.

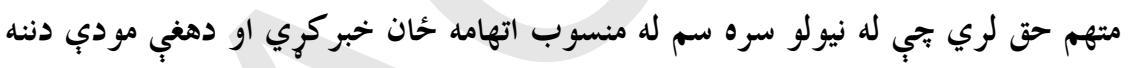

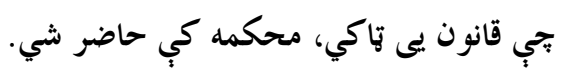

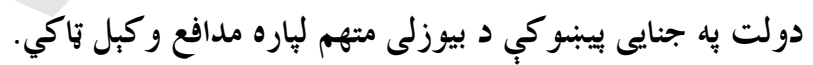

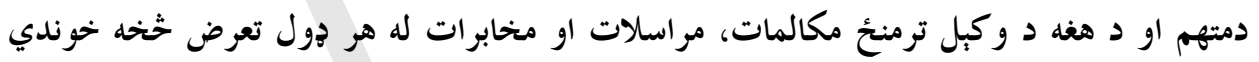
د مدافع و كبلانو وظايف او واكونه د قانون له لارى تنظيميب.ي.《

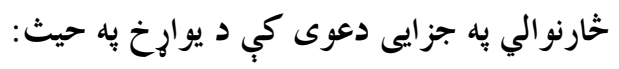

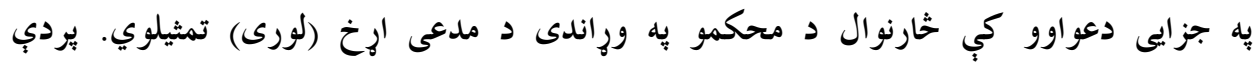

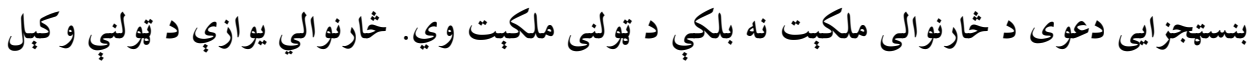

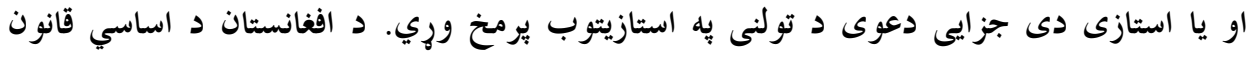

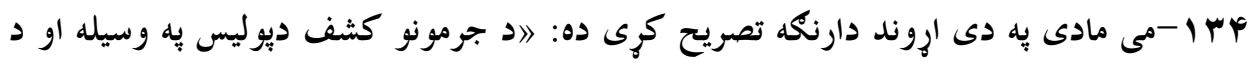


جرمونو تحقيق او به محكمه كي ير متهم باندي د دعوا اقامه د خارنوالي له خوا، د قانون له احكامو

$$
\text { سره سم كبوب. }
$$

خارنوالي د اجرائيه قوى برخه ده ار به خجيلو اجر آتو كي استقلال لري.

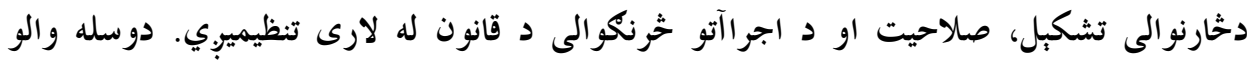

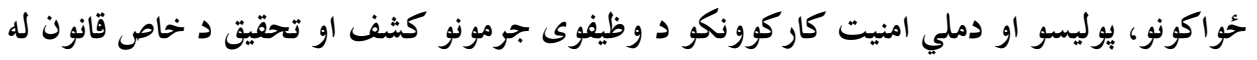
لارى تنظيميوي.

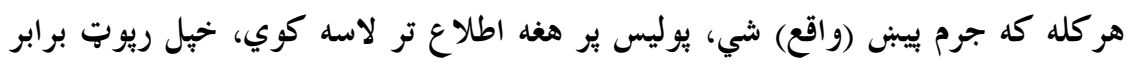

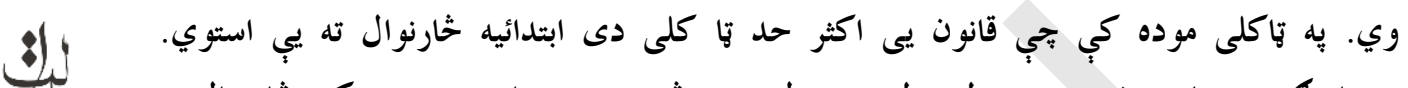

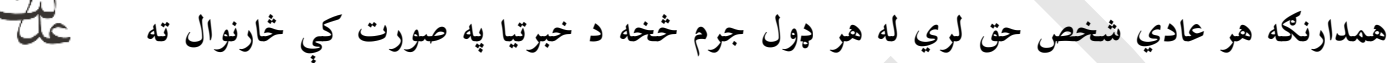

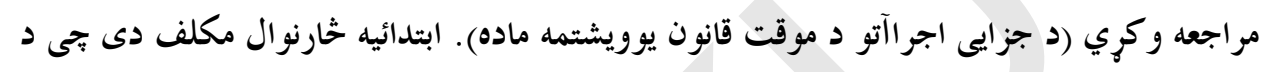

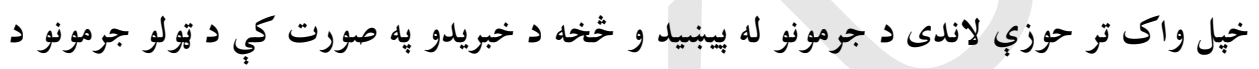

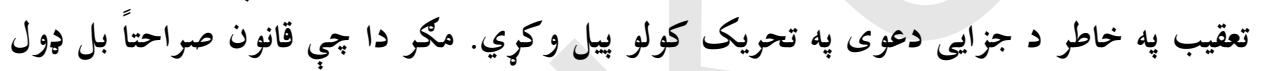

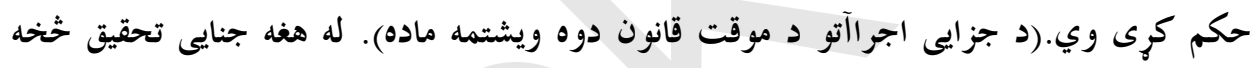

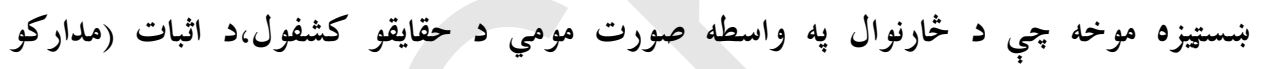

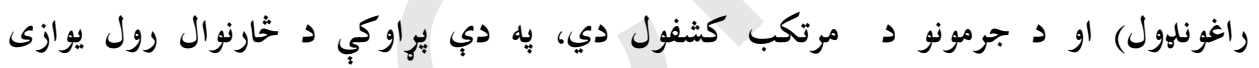

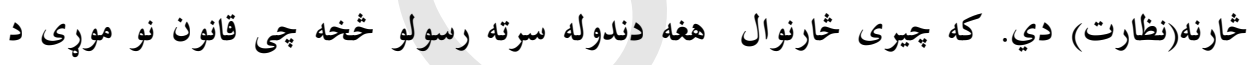

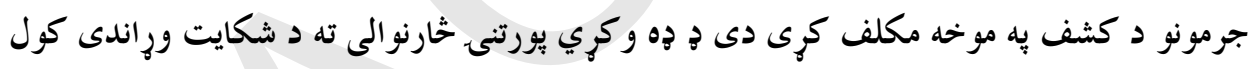

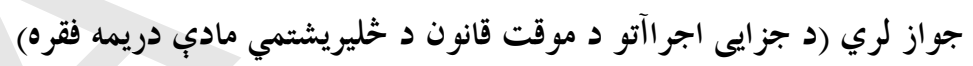
د جزايى دعوى بيراوونه:

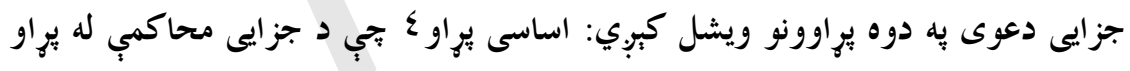

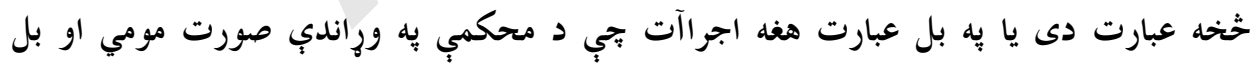

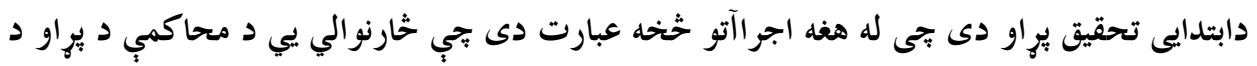
تيارو لويه موخه ترسره كوي.

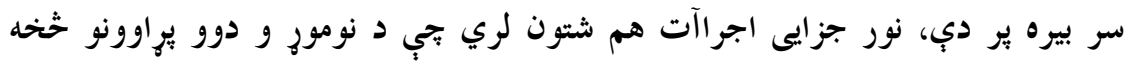

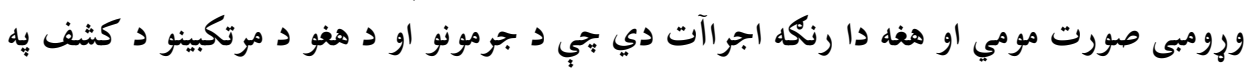




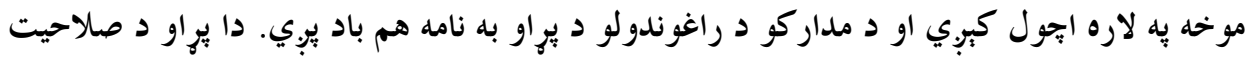

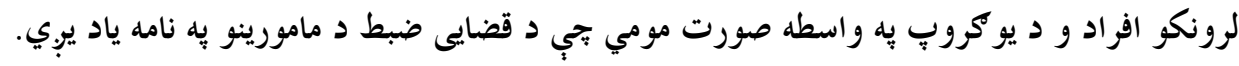

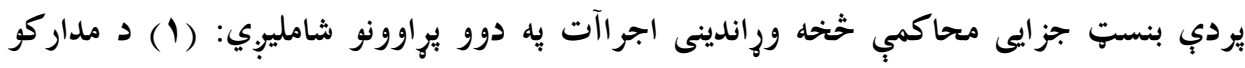

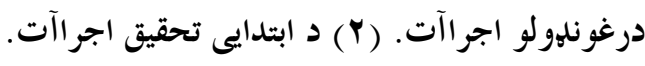

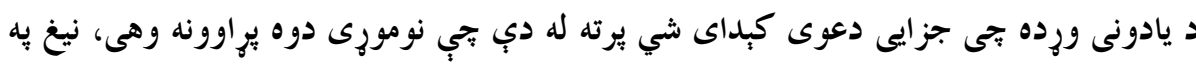

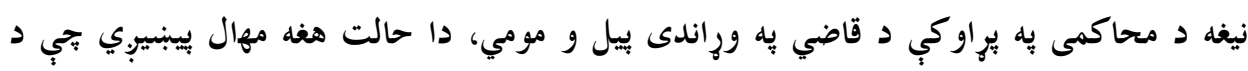

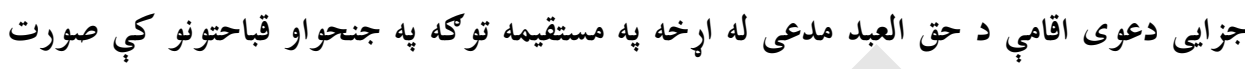

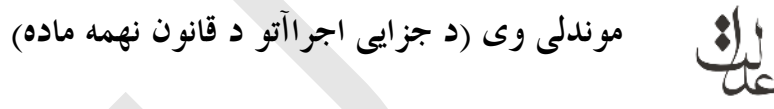




\section{رئيس جديد ادارى و مالى وزارت عدليه معرفى ترديد}

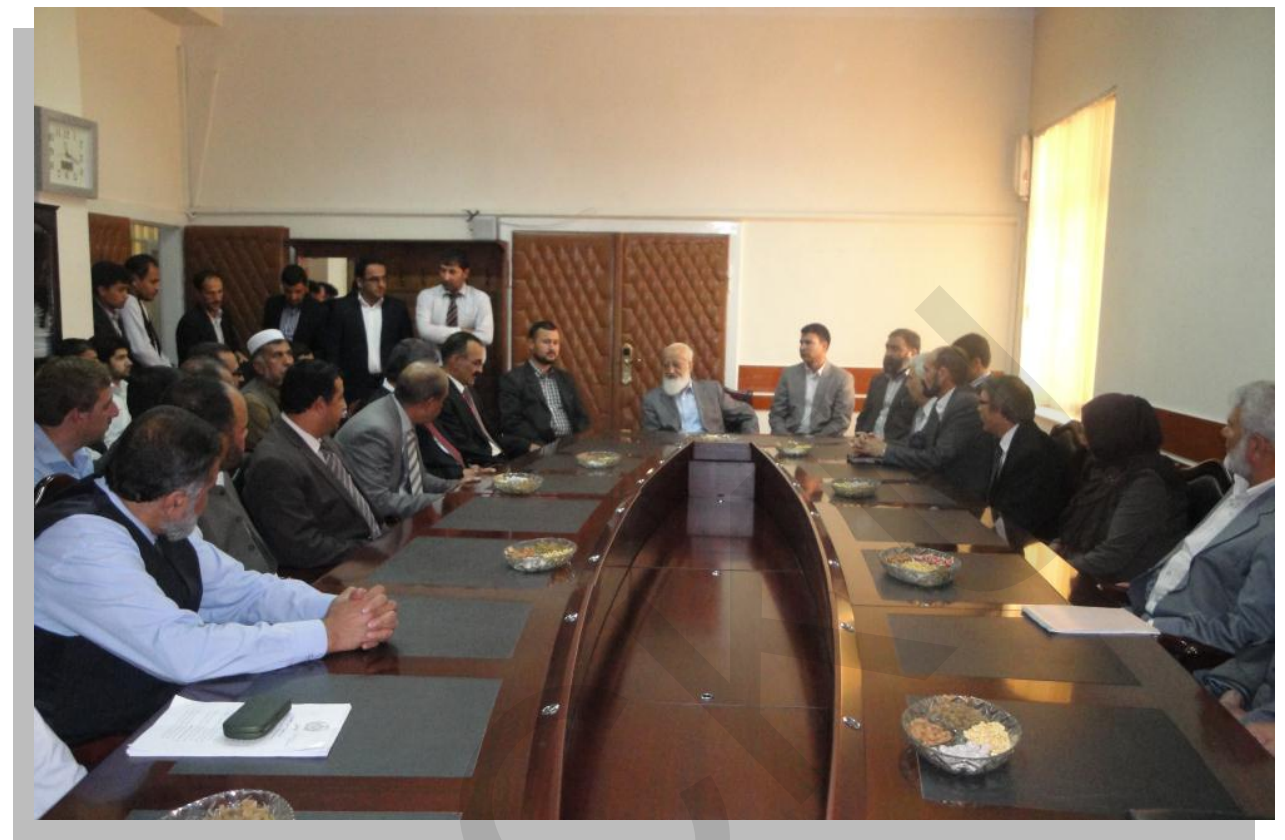

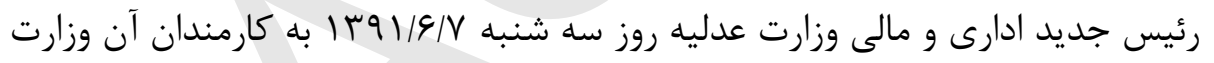

$$
\text { معرفى زرديد. }
$$

در محفلى كه به همين مناسبت در وزارت عدليه داير گرديده بود، خارنيوه حبيب الله

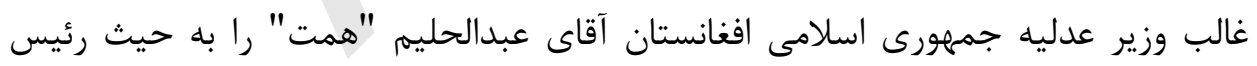

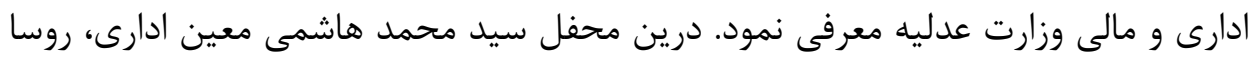

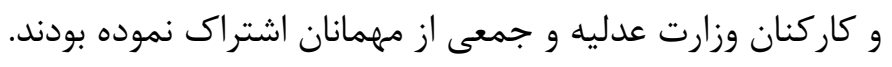

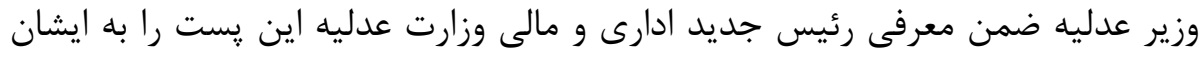
تبريك كفته و ايشان را متوجه مسئوليت هاى خطيرى كه در قدئ قبال مردم و و جامعه دارند

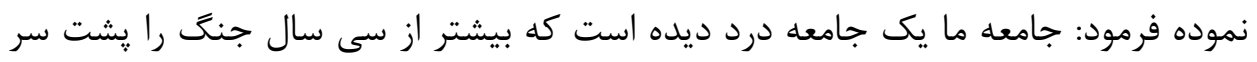

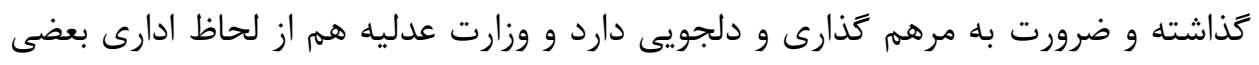


مشكلات دارد خصوصاً حالاكه مسئله فرمان رئيس جمهور، موضوع تطبيق يُلان هاى

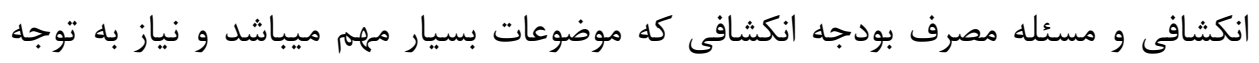

$$
\text { بيشتر دارد. }
$$

بعداً آقاى همت از اعتماد كه نسبت به وى صورت كرفته اظهار سياس و قدردانى نموده و

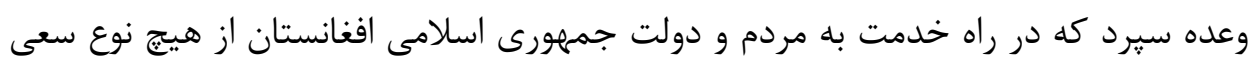

$$
\text { و تلاش دريغ نخواهد ورزيد. }
$$

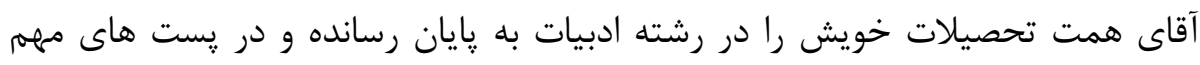

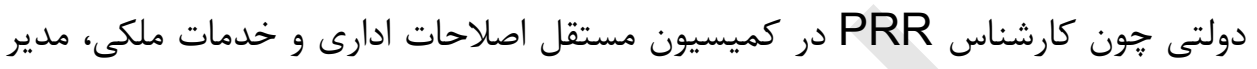

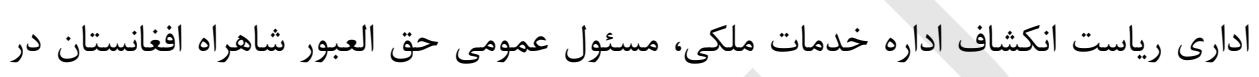

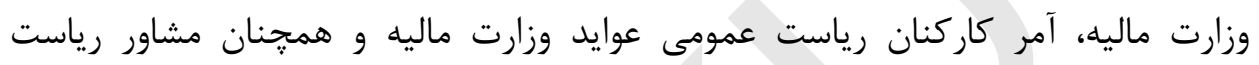
عمومى بودجه در وزارت ماليه ايفاى وظيفه نموده است.كوى.

$$
\text { منبع: آمريت مطبوعات }
$$




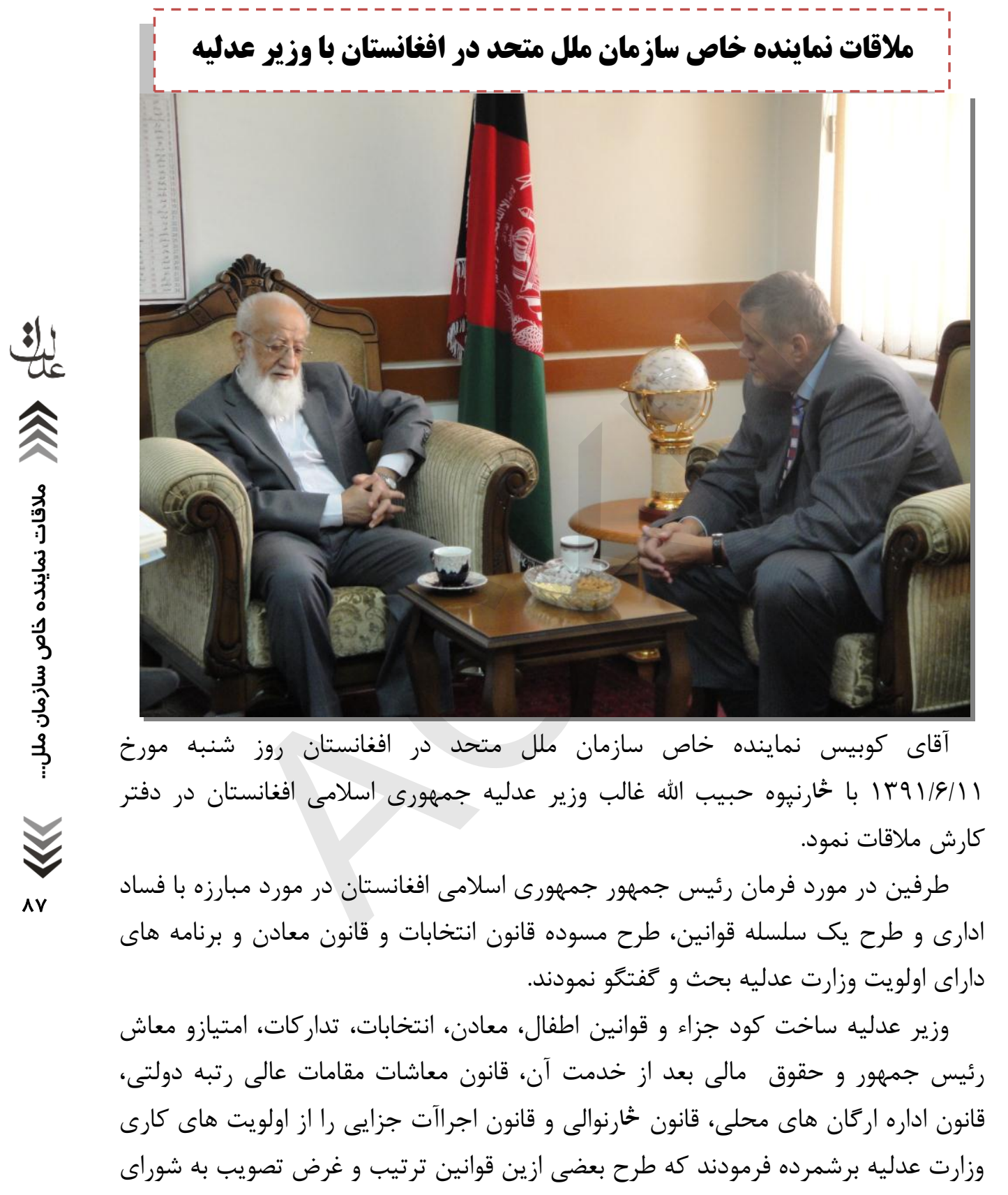


وزيران و شوراى ملى فرستاده شده و كار روى جكونكى طرح و تصويب تعداد از آنها جريان

وزير عدليه در مورد جَكَونكَى طرح قانون انتخابات فرمودند: ما از كميسيون مستقل

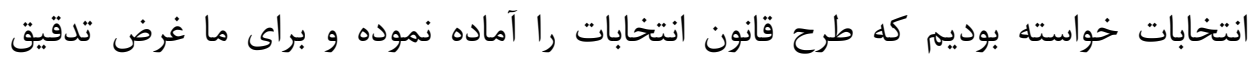

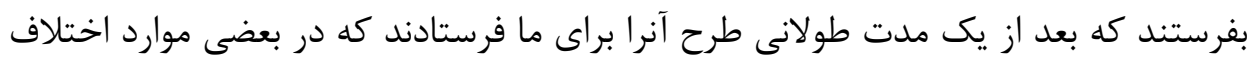

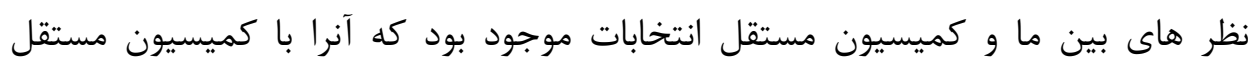

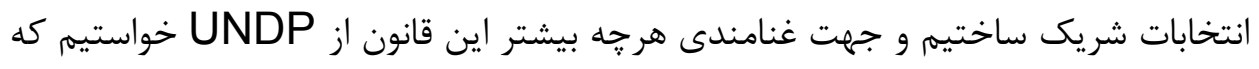

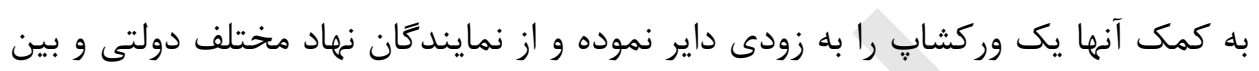

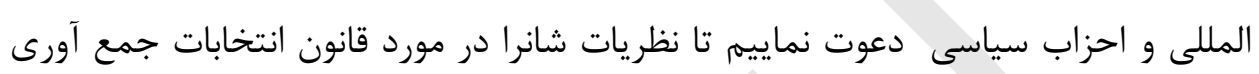

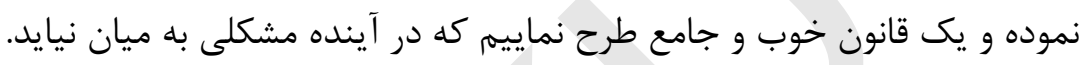

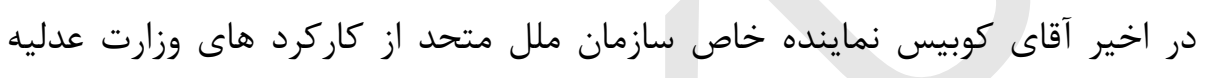

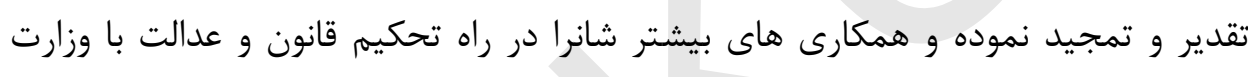
عدليه وعده نمودند.

منبع: آمريت مطبوعات 


\section{بازديد جلالتماب وزير عدليه از ولايت هرات باستان}

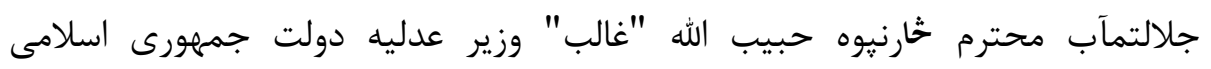

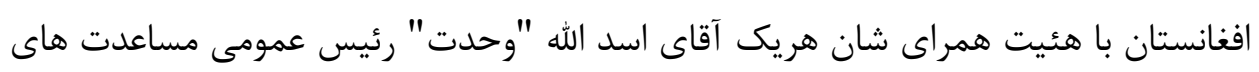

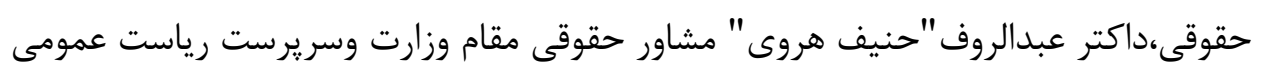

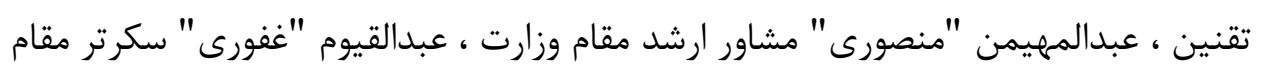

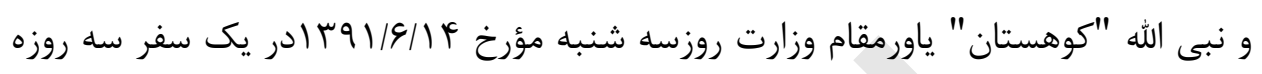

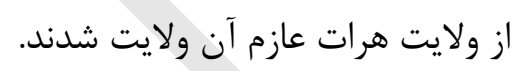

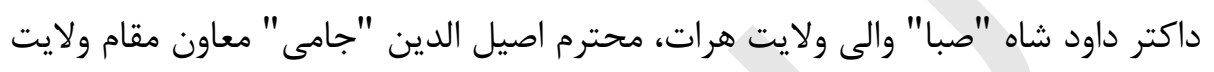

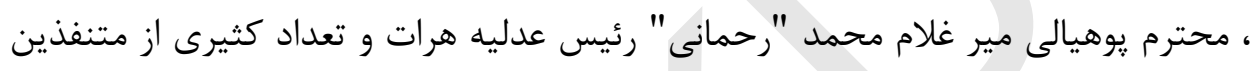

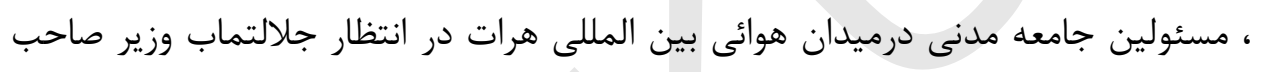

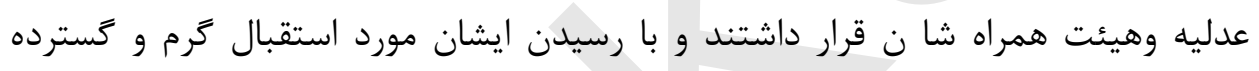

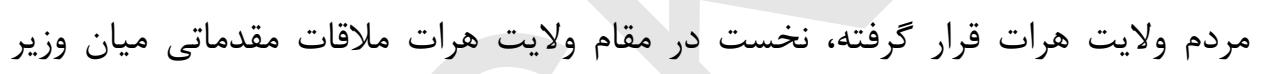

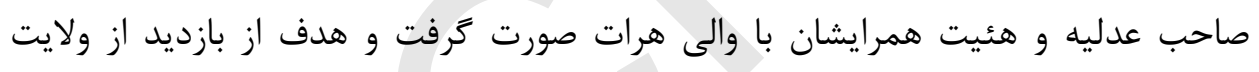

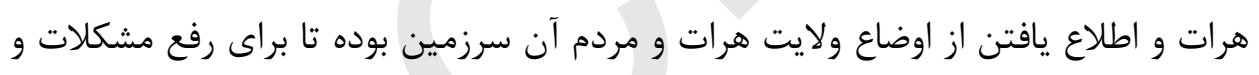

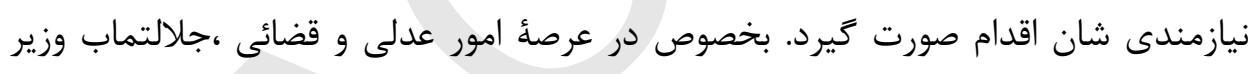

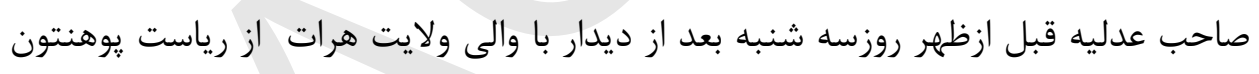

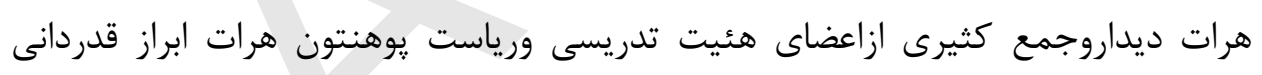

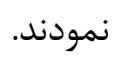

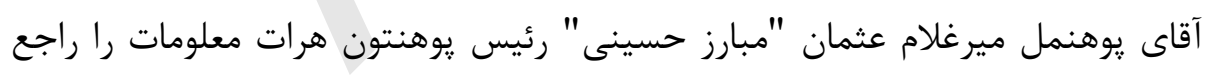

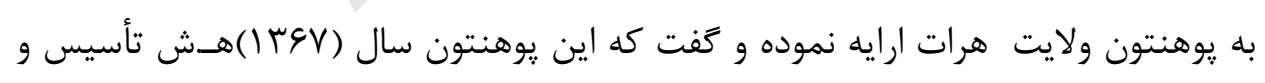

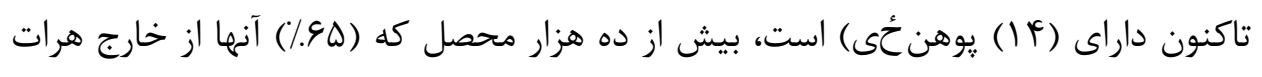

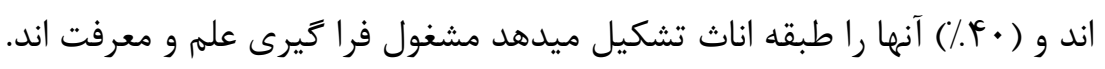

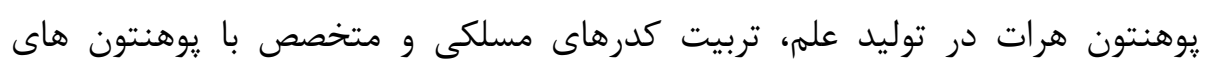

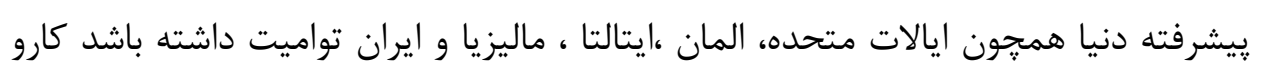

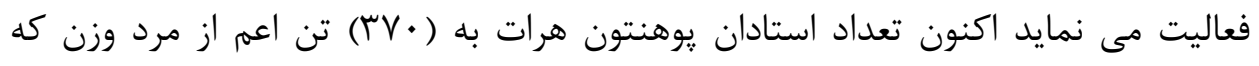


(بس//) آنان به درجه عالى ماسترى نايل گرديده اند.و يك تعدادى هم از ايشان مصروف فراگيرى مرحله دكتورا قرار دارند.

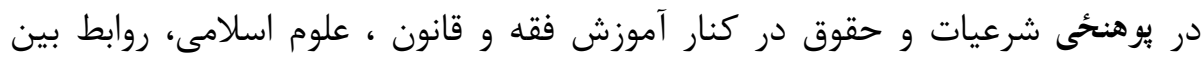

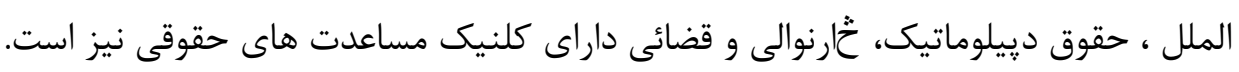

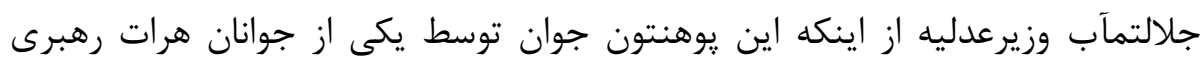

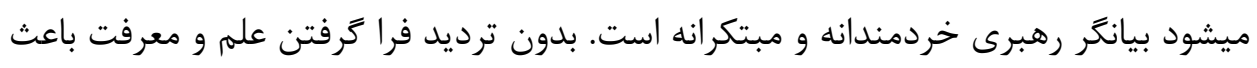

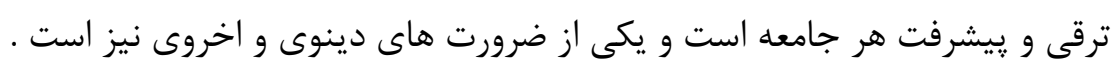

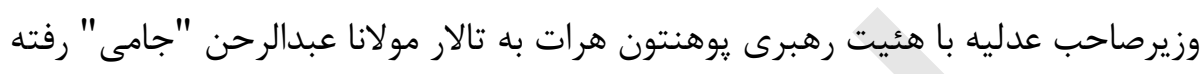

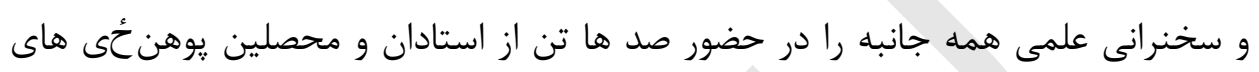

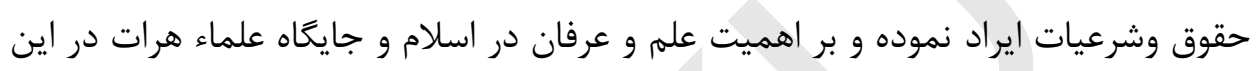

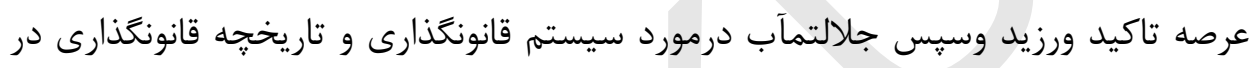

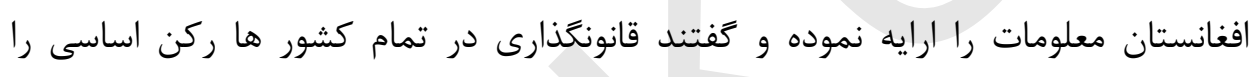

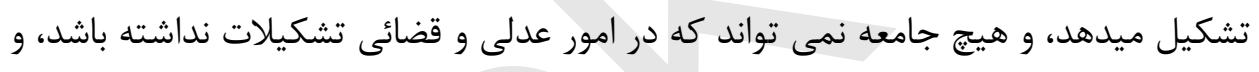

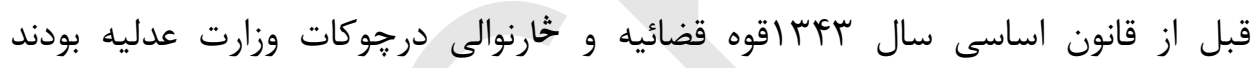

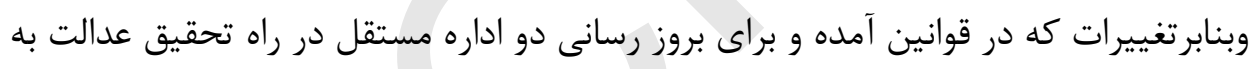
بهترين وجه آن بوجود آمدند. گر جه ازصدراسلام در تمام دوره ها مستقلانه كار نموده خلفاء مقتدر اسلام به قضان

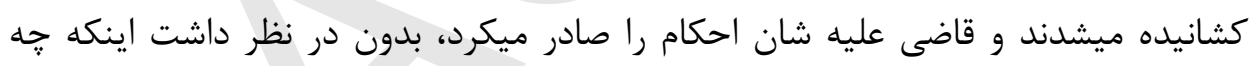

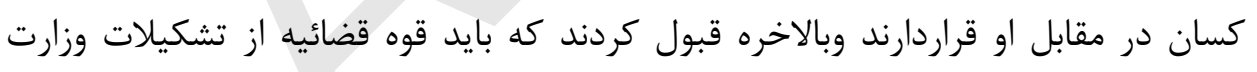

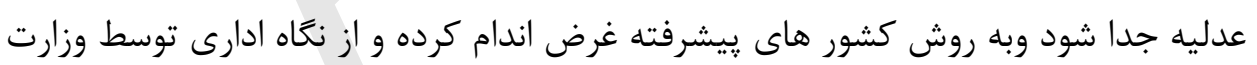
عدليه اداره ميشد .

و درعرصه قانونكذارى وزير عدليه به فعاليت اميرشير على خان اشاره نموده كه در دوران

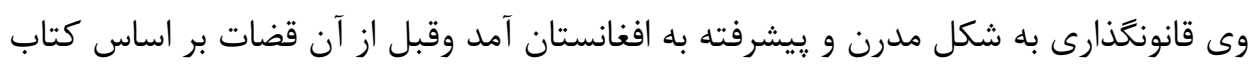
هاى فقه ، قضايا را حل و فصل ميكردند .

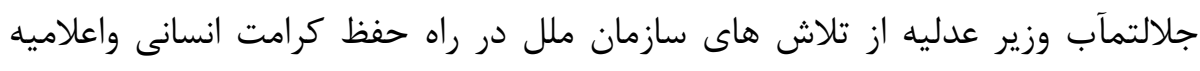

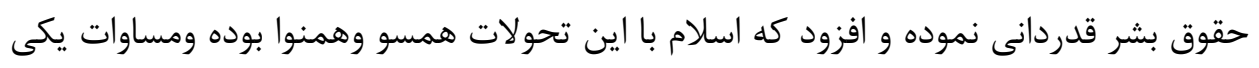

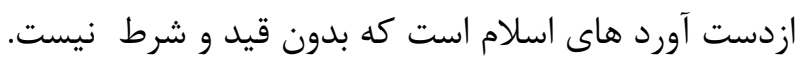


اگر جه افغانستان به معيار هاى بين المللى ، منشور سازمان ملل متحد و اعلاميه حقوق

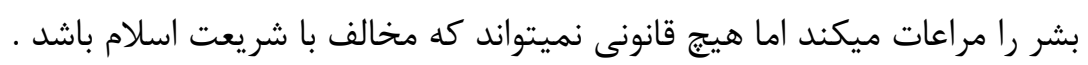

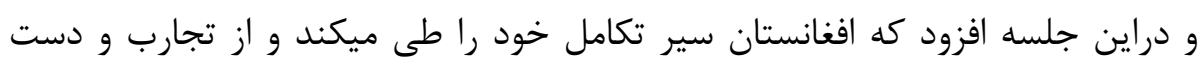
آورد هاى جهانى به سود مردم و جامعه استفاده ميكند .

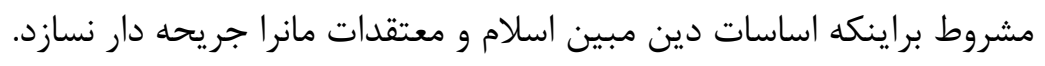

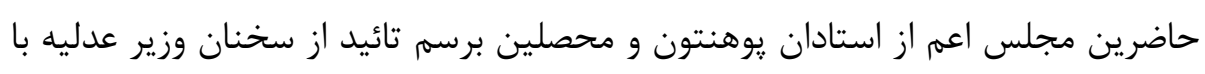

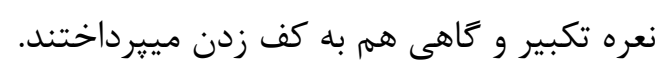

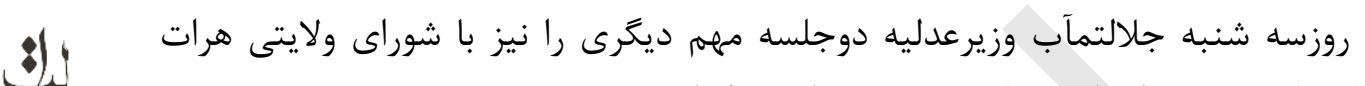
ونهاد هاى مدنى و احزاب سياسى ولايت هرات بر خزار نمود.

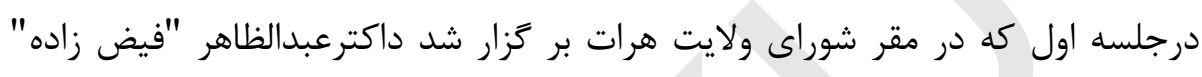

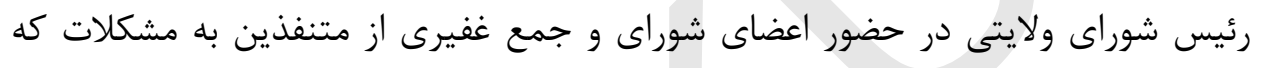

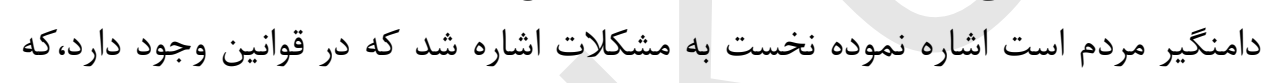

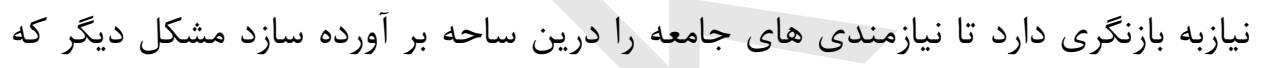

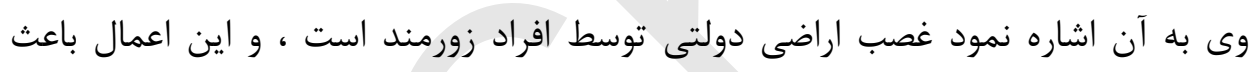
فاصله كيرى مردم از دولت ميشود.

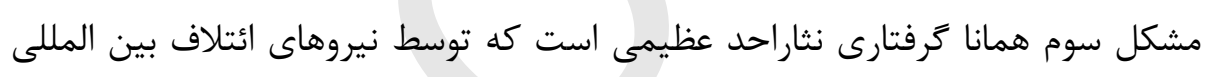

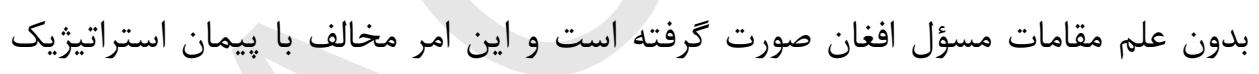

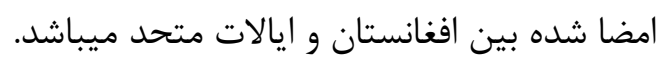

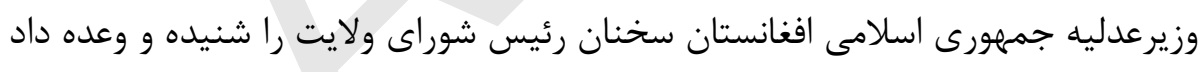

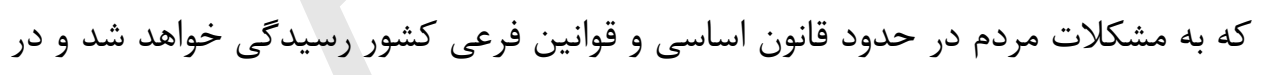

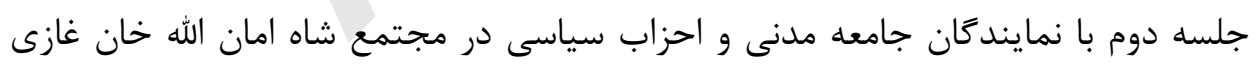

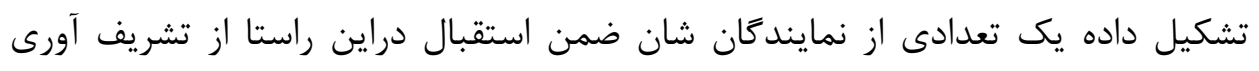

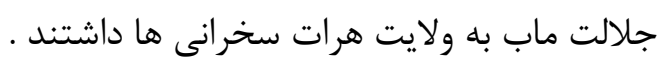

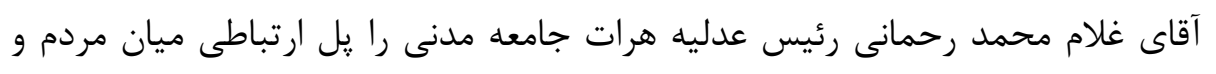

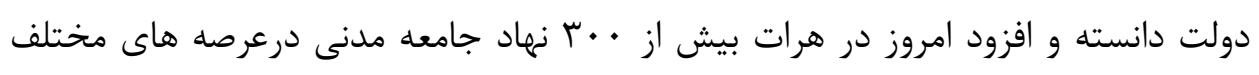

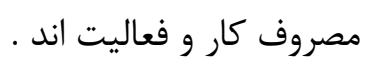
ايشان در سخنان خويش روى نكات ذيل تمركزداشتند. 
() دولت ها از بسترملت ها بوجودميآيند ، بايد به نهاد هاى جامعه مدنى اهتمام بيشترى

$$
\text { صورت بخيرد و تغذيه كردد. }
$$

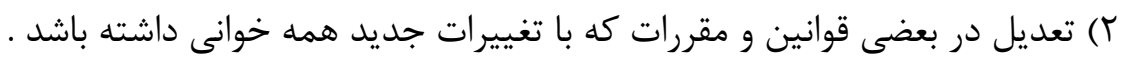

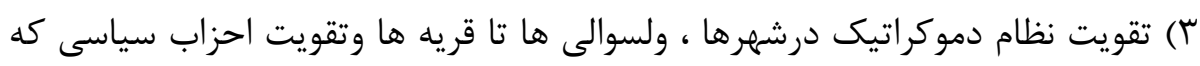

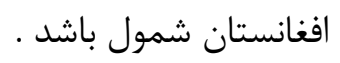

دريايان سخرانى نمايندگان جامعه مدنى آقاى توكلى يكى ازعلماى دئى دينى صحبت نموده

و طبق فرموده خداوندمتعال \}اعدلوا هو اقرب للتقوى

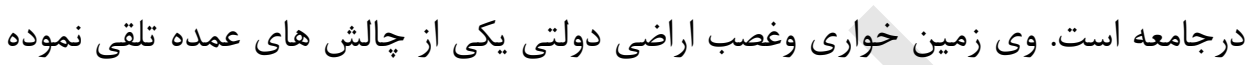

$$
\text { كه توسط زورمندان اعمال ميشود. }
$$

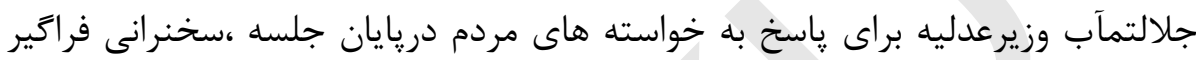

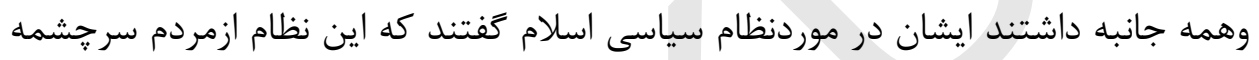

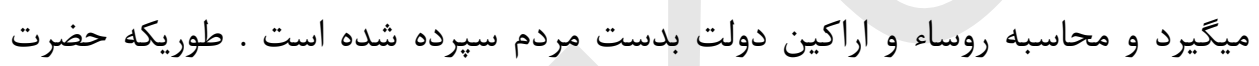

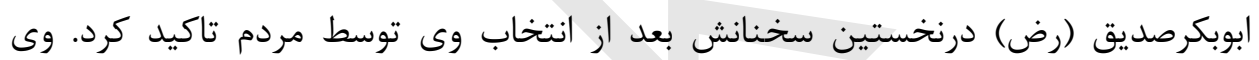

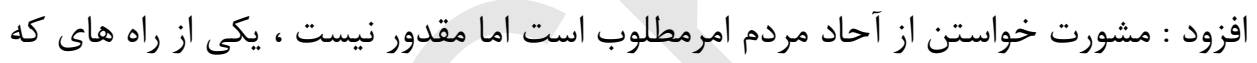

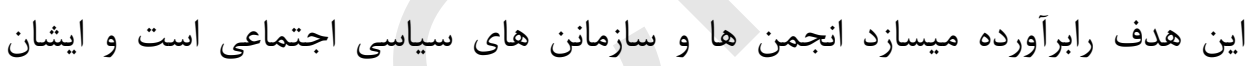
ميتوانند نقش سازنده را در اصلاح جامعه بر عهده بخيرند.

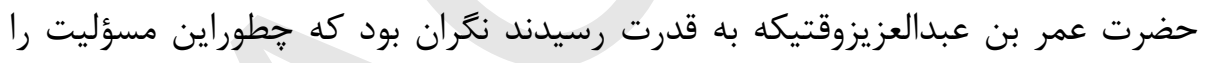

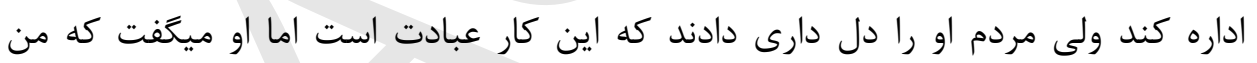

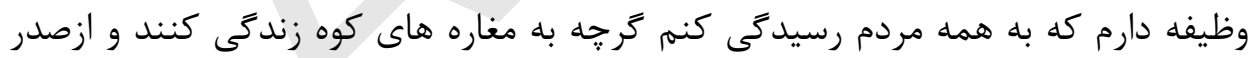

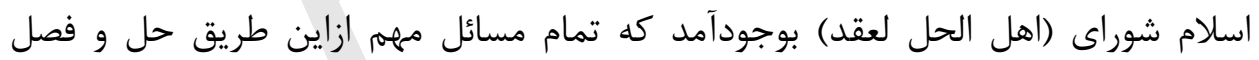

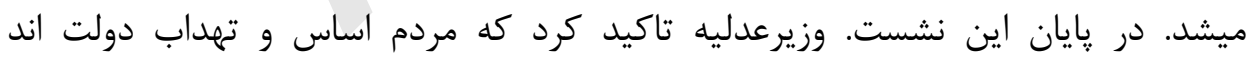

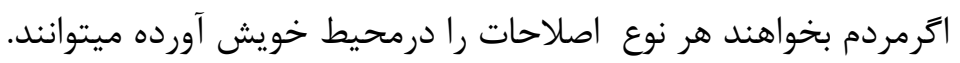

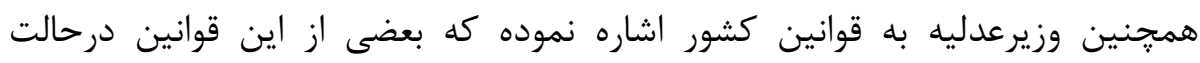
بازنخرى است .

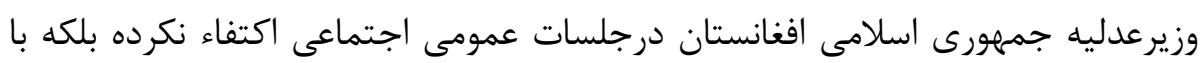

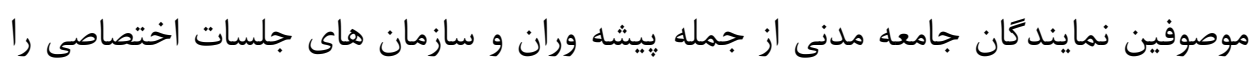


بركزارنمودند از ززاف بودن ماليات وتكس ها كه ادارات مربوط از نزدشان اخذ مى نمايد شكايت داشتند

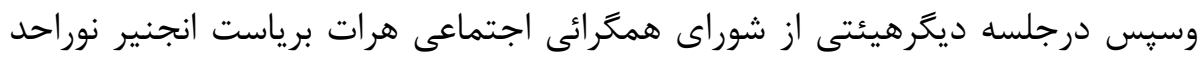

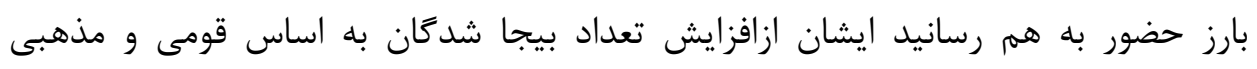

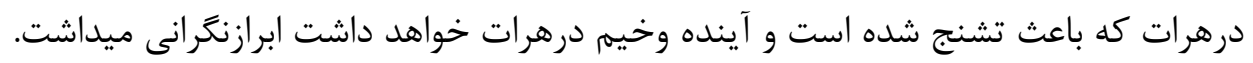

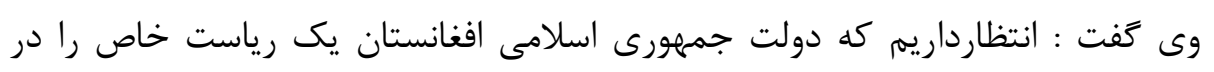

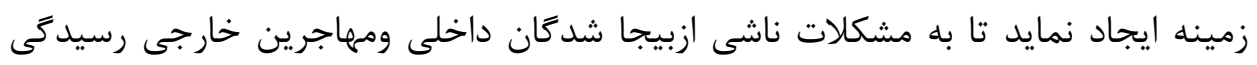
صورت كيرد.

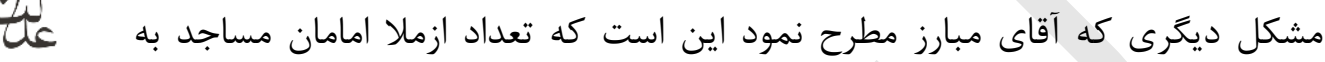

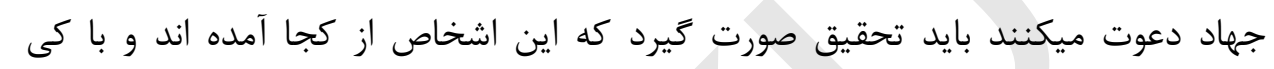

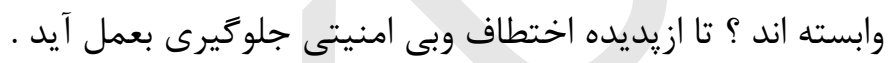

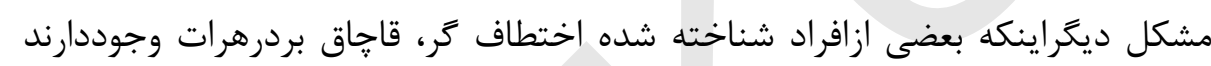

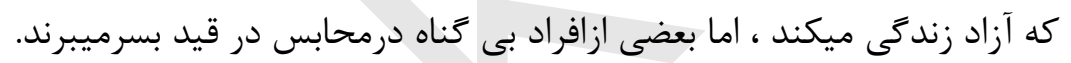

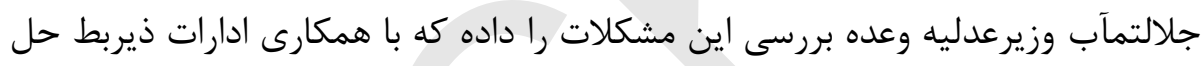
خواهد شد.

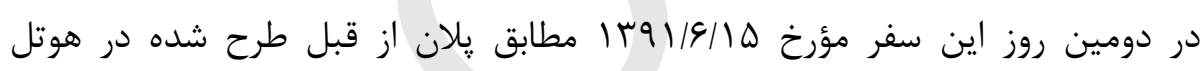

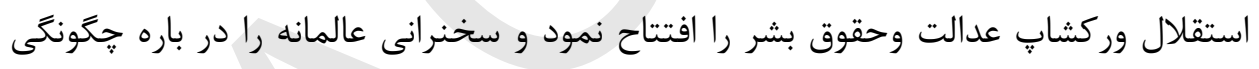

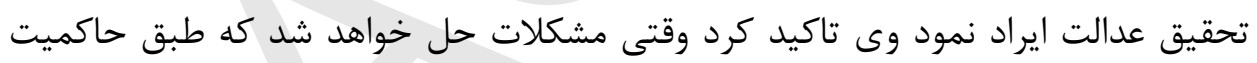

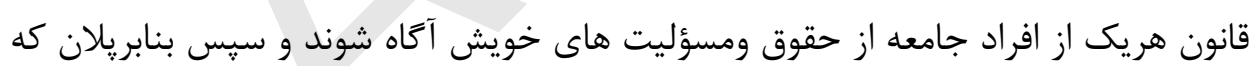

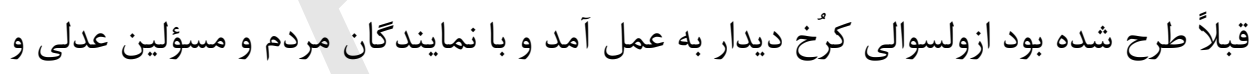

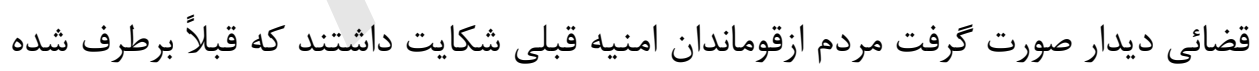
همجنين ازنبود برق نيزشاكى بودند همزمان از آمر حقوق ولسوالى كُُخ شكايت به عملى

جلالتمآب وزيرعدليه به مشكلات مردم استماع نموده وبراى اصلاح درحيطه صلاحيت

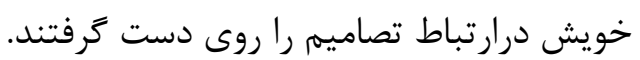


درهمين روز از ارگ اختيارالدين نيزديداربه عمل آورد كه اين قلعه بيانكَر تمدن و فرهنَ

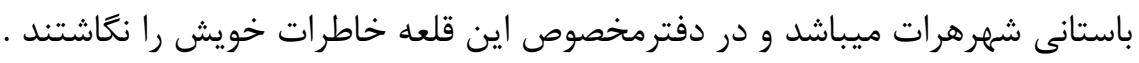

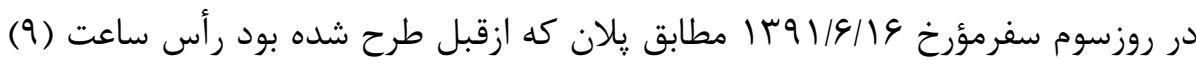

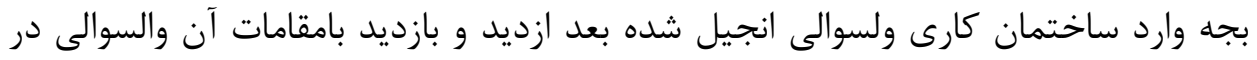

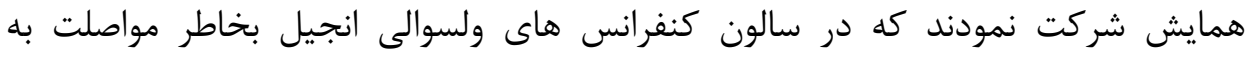

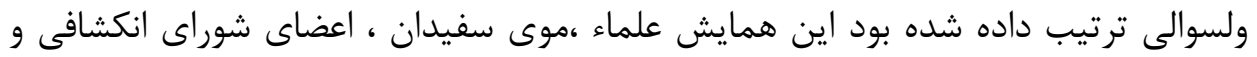

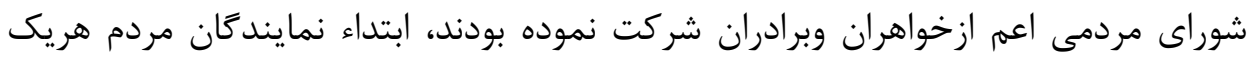

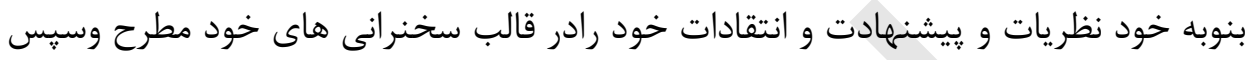

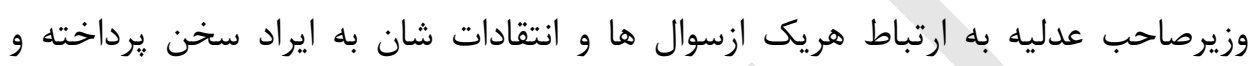

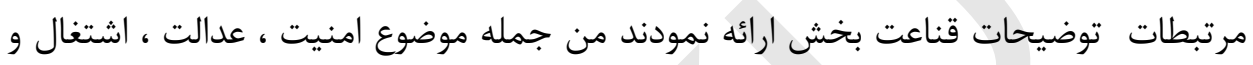

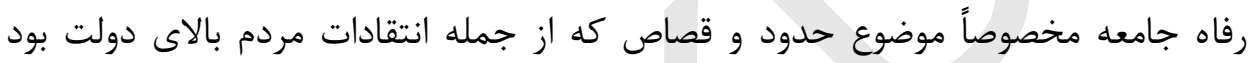

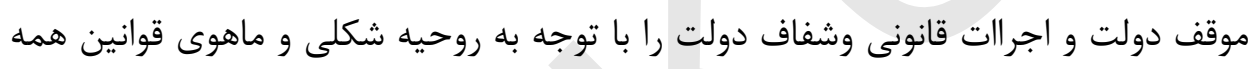

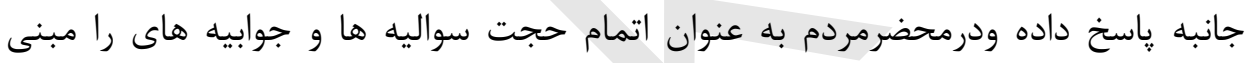

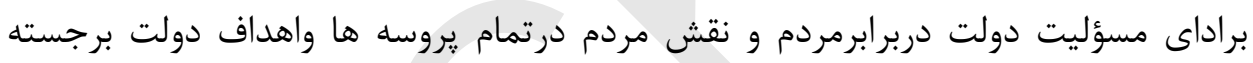
ساخته كه ازجو موجود قناعت حاضرين بوضوح دور دانسته ميشد.

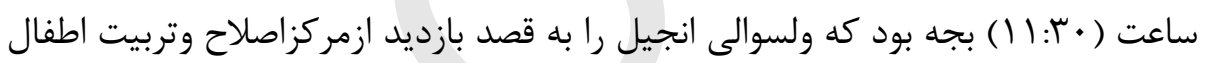

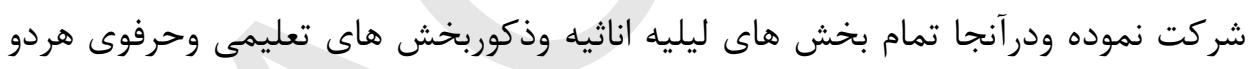

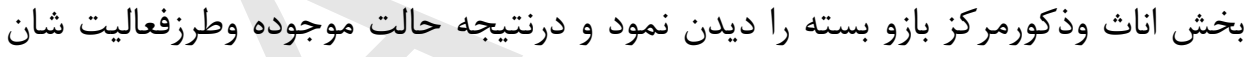

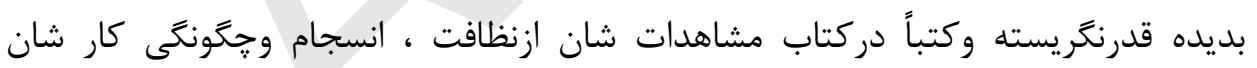
تحسين و تقدير به عمل آمد و درقسمت تعيين سن اطفال تذكرداده شد، تا مؤكداً سن اطفال

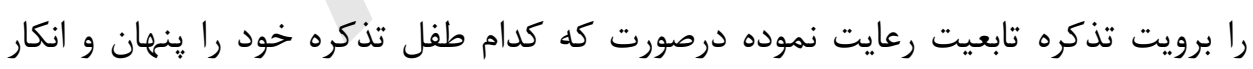

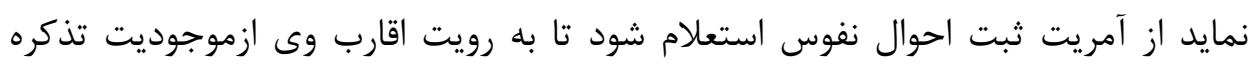

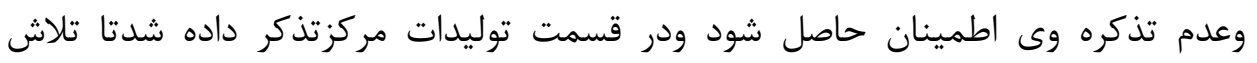

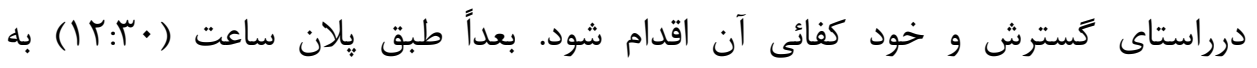

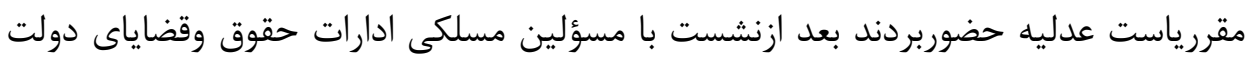

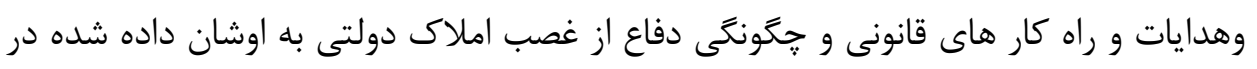

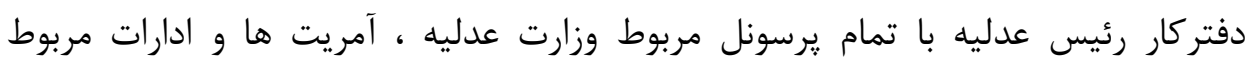


بشمول بعضى از ولسوالى ها ديدار و استماع مشكلات ونظريات شان نموده سيس رهنمائى

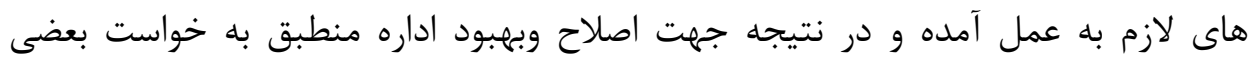

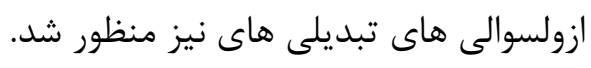

منبع: آمريت مطبوعات

$\underbrace{8 / 4}_{0}$

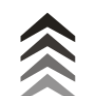

iे

रे

告:

$\overline{2}$

ते?

$\frac{2}{3}$

90 


\section{بركزارى كنفرانس علمى براى اعضاى مسلكى رياست تقنين وزارت عدليه}

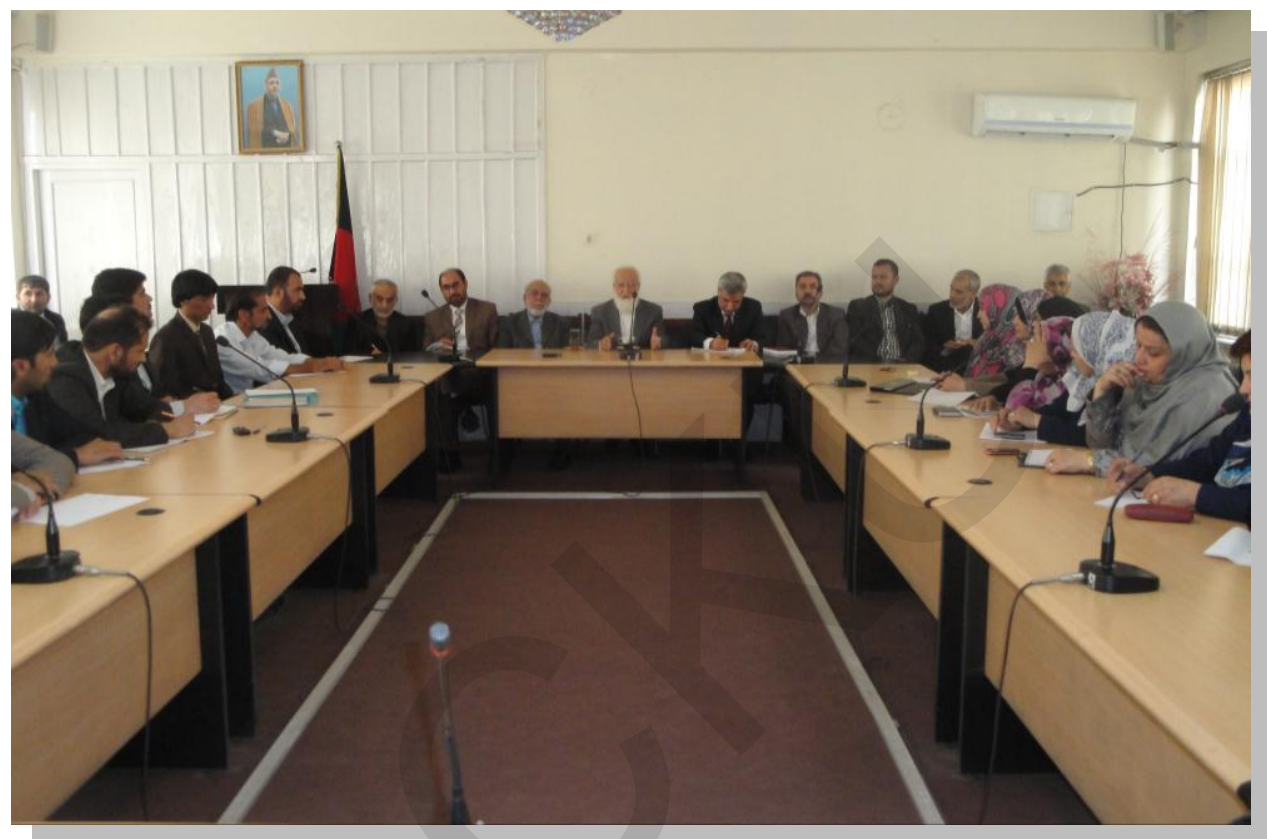

كنفرانس علمى يك روزه براى اعضاى مسلكى رياست عمومى تقنين وزارت عدليه روز

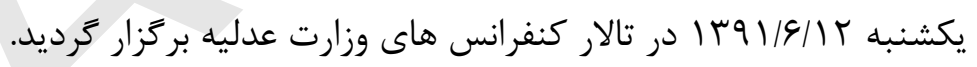

درين كنفرانس روسا و اعضاى مسلكى دييارتمنت هاى مختلف رياست عمومى تلفى تقنين اشتراك نموده بودند.

درين كنفرانس كه غرض ارتقاى سطح دانش مسلكى اعضاى تقنين برَزار شده بود بود

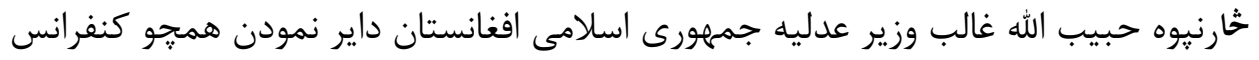

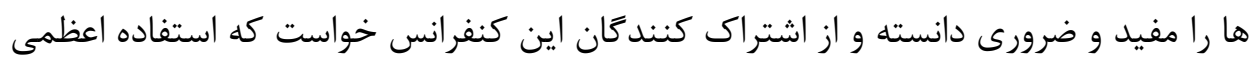
را از همجو كنفرانس ها داشته باشند.

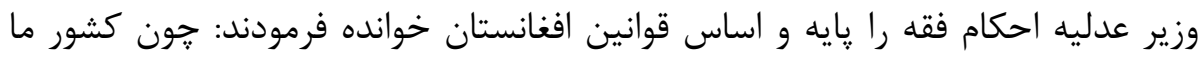
يك كشور اسلامى است و به اساس قانون اساسى كشور هيج قانونى خلاف احكام و قوانين 
اسلامى در كشور ما پِياده شده نميتواند، لذا آموختن احكام فقه براى اعضاى تقنين يك امر أراء

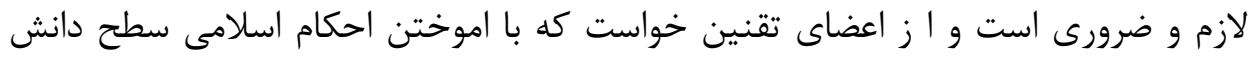

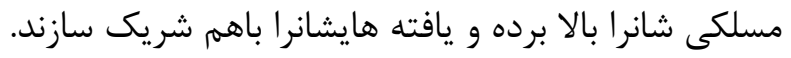

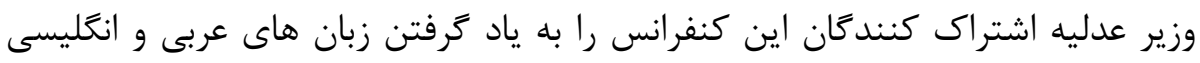

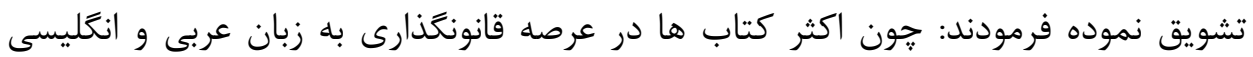

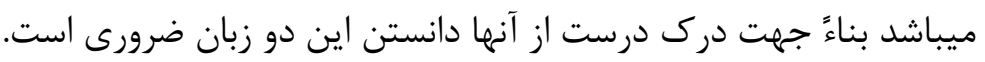

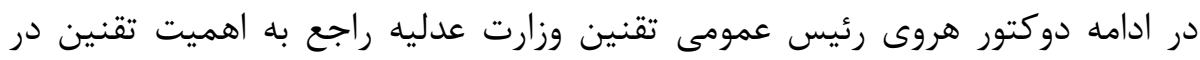

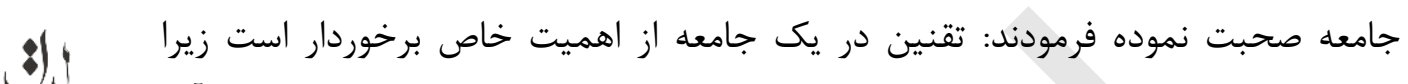

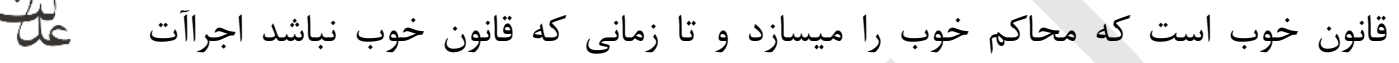
خارنوالى و محاكم هم خوب نخواهد بود.

تحقق عدالت هدف اساسى وزارت عدليه ميباشد و تمام قوانين كه در دنيا ساخته ميشود

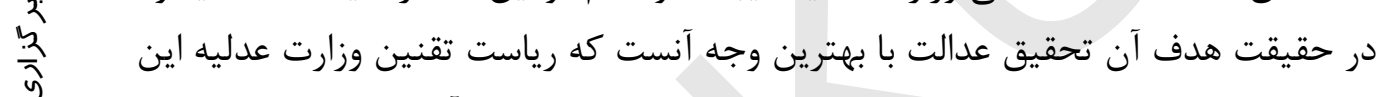

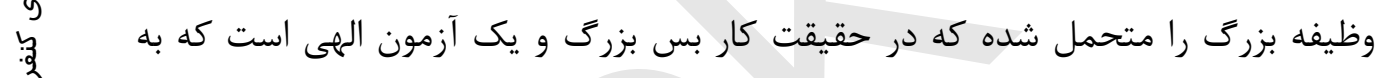

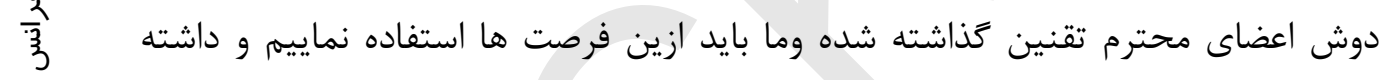

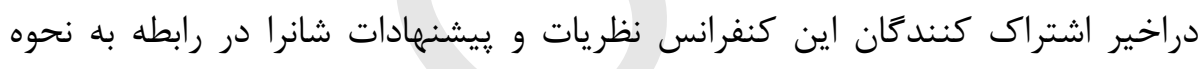

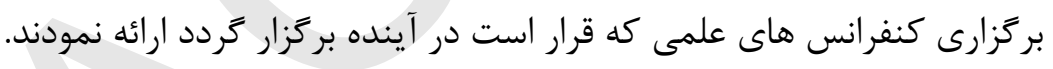

منبع: آمريت مطبوعات 


\section{تدوير ور كشاب بررسى طرح قانون انتخابات}

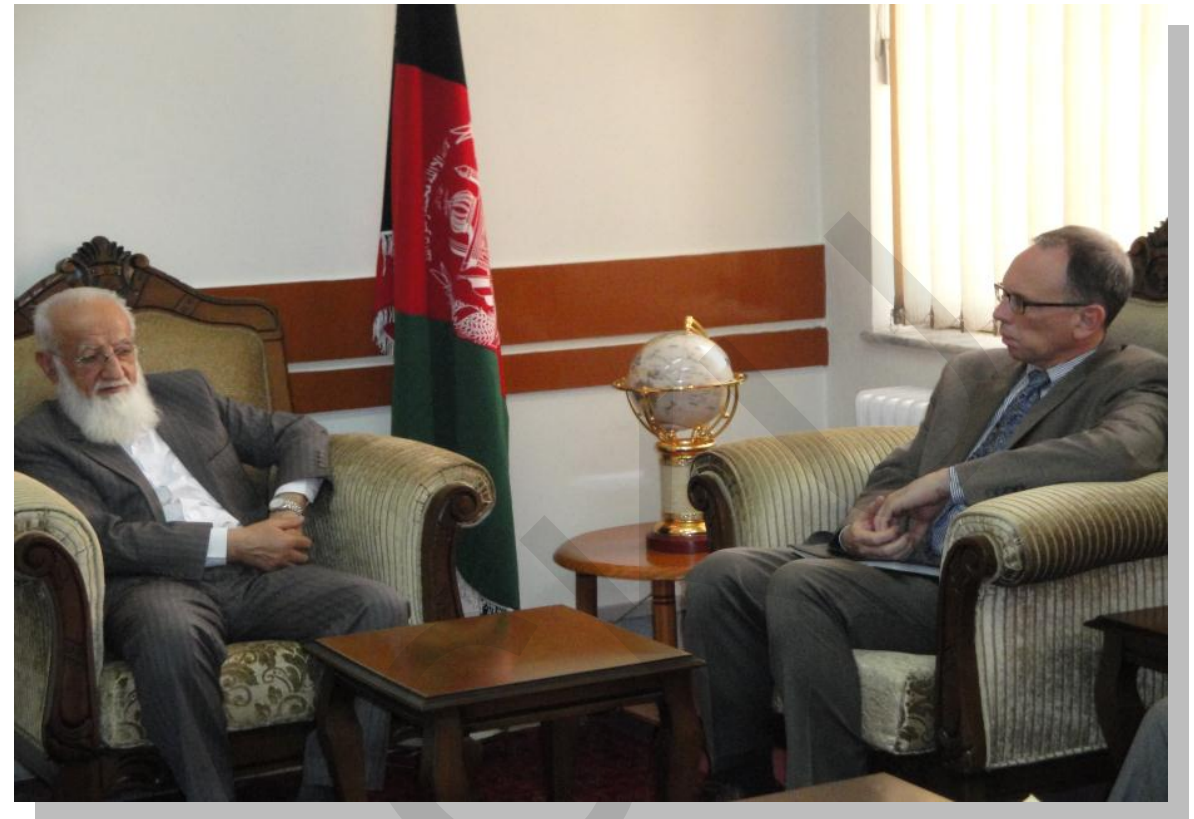

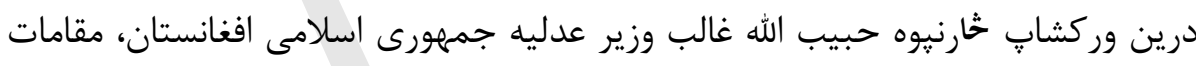

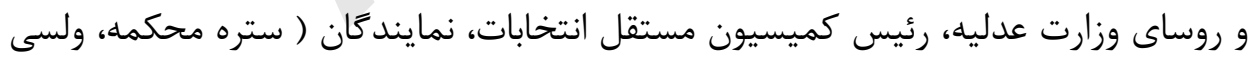

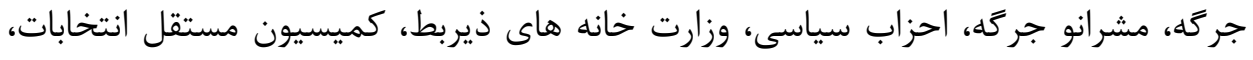

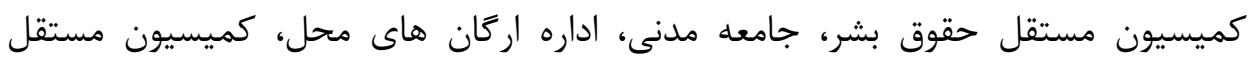

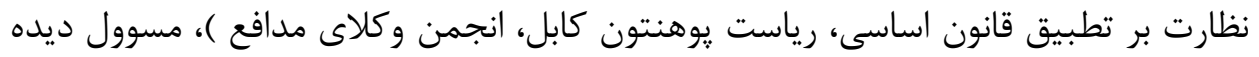

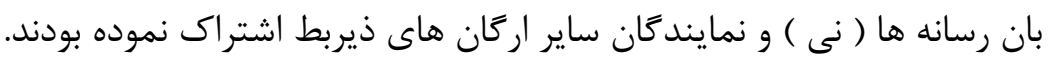

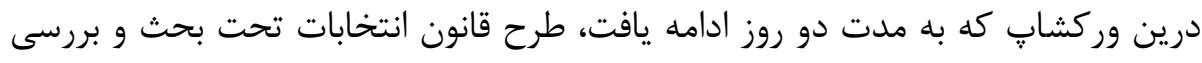

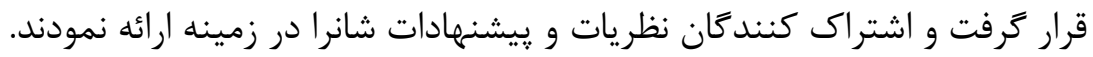


در ابتداى اين وركشاب وزير عدليه پِيرامون موضوع صحبت نموده فرمودند: قانون

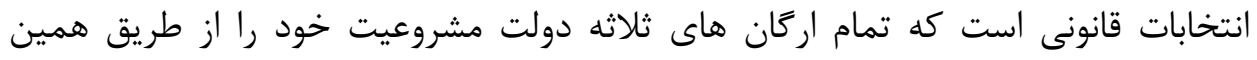

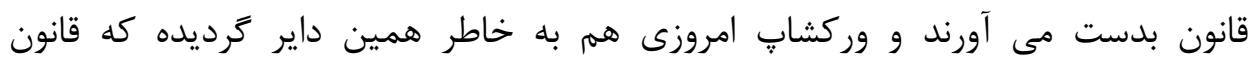

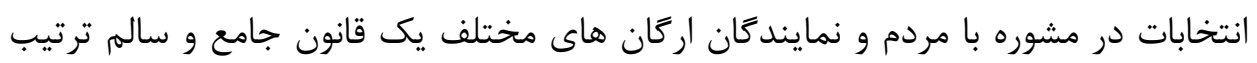

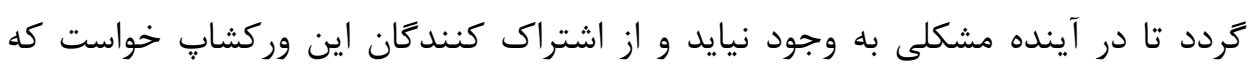

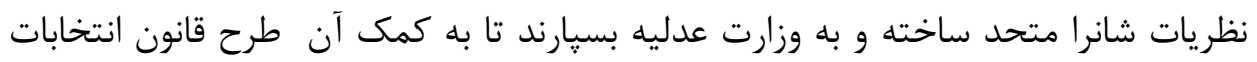
ترتيب تردد.

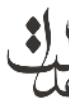
منبع: آمريت مطبوعات 
A Tulwo

KNE

2720

248

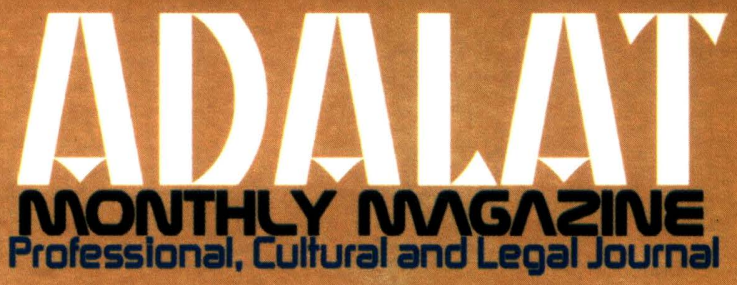

